Universidade de Brasília - UnB

Faculdade de Ciência da Informação - FCI

Programa de Pós-Graduação em Ciência da Informação

Raquel Pereira Costa

\title{
Modelos de comercialização de livros eletrônicos para bibliotecas do Distrito Federal
}


RAQUEL PEREIRA COSTA

\section{Modelos de comercialização de livros eletrônicos para bibliotecas do Distrito Federal}

Dissertação apresentada ao Programa de PósGraduação em Ciência da Informação da Universidade de Brasília como requisito parcial para obtenção do grau de Mestre em Ciência da Informação.

Orientador: Prof. Murilo Bastos da Cunha Área de concentração: Gestão da Informação Linha de pesquisa: Organização da Informação 


\section{C837m Costa, Raquel Pereira.}

Modelos de comercialização de livros eletrônicos para bibliotecas do Distrito Federal- Brasília (2015)/Raquel Pereira Costa. - Brasília, 2015.

$186 \mathrm{f}$.

Dissertação (Mestrado em Ciência da Informação) Universidade de Brasília, Faculdade de Ciência da Informação, 2015.

Orientador: Prof. Murilo Bastos da Cunha Bibliografia

1.Livro eletrônico. 2. Aquisição bibliográfica. I. Título. 
Faculdade de Ciência da Informação e Documentação - FC

Programa de Pós-Graduação em Ciência da Informação - PPGCINF

\section{FOLHA DE APROVAÇÃO}

Título: "Modelos de comercialização de livros eletrônicos para bibliotecas do Distrito Federal."

Autor (a): Raquel Pereira Costa

Área de concentração: Gestão da Informação

Linha de pesquisa: Organização da Informação

Dissertação submetida à Comissão Examinadora designada pelo Colegiado do Programa de Pósgraduação em Ciência da Informação da Faculdade em Ciência da Informação da Universidade de Brasília como requisito parcial para obtenção do título de Mestre em Ciência da Informação.

Brasília, 11 de dezembro de 2015.
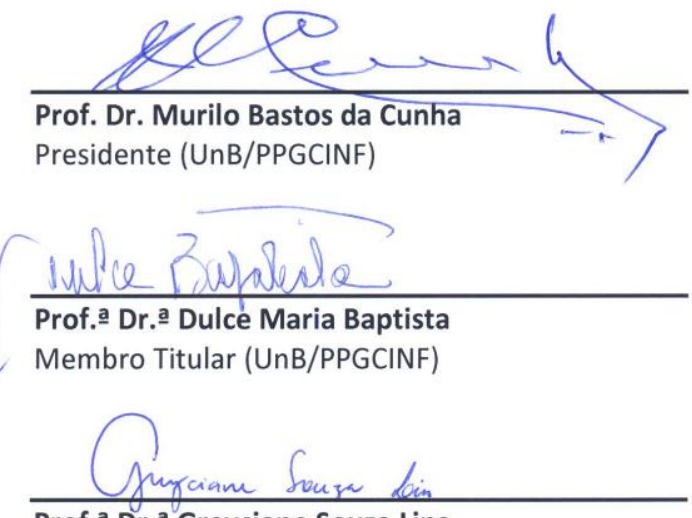

Prof.a Dr.a Greyciane Souza Lins

Membro Titular (UNIEURO)

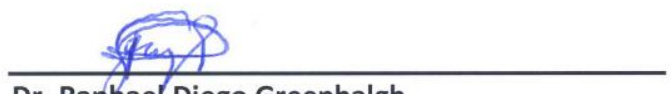

Dr. Raphae/ Diego Greenhalgh

Membro Suplente (UnB)

Edifício da Biblioteca Central (BCE) - Entrada Leste - Campus Universitário Darcy Ribeiro - Asa Norte - Brasília, DF CEP 70910-900 - Tel.: +55 (61) 3107-2632 - Telefax: +55 (61) 3107-2633 -E-mail: pgcinf@unb.br 


\section{RESUMO}

Este trabalho busca identificar os modelos de comercialização utilizados na aquisição de livros eletrônicos para bibliotecas do Distrito Federal. Inicialmente, identifica o conceito de livro eletrônico, seus formatos mais comuns e os aparelhos e programas utilizados para a sua leitura. Em seguida, identifica e analisa os modelos existentes de comercialização de livros eletrônicos para bibliotecas e os vendedores, que costumam ser editoras, agregadores ou distribuidores. São analisados os modelos de seleção disponíveis para as bibliotecas, dos quais os mais comuns são por título, por pacote ou por plano de aprovação. Esses modelos de negócios incluem o acesso perpétuo, a assinatura, o empréstimo de curto prazo e a aquisição orientada pelo usuário. Destaca os aspectos relacionados ao contrato de venda de livros eletrônicos e à necessidade de uma política de renovação e cancelamento das assinaturas; foca também nos direitos autorais e na gestão desses direitos, bem como em experiências de outras bibliotecas com livros eletrônicos. Analisa os resultados da pesquisa realizada com bibliotecas do Distrito Federal que compraram livros eletrônicos, comparando esses resultados com a literatura anteriormente citada.

Palavras-chave: Aquisição bibliográfica. Biblioteca digital. Desenvolvimento de coleções. Livro eletrônico. 


\begin{abstract}
This paper seeks to identify the business models used for the acquisition of electronic books for libraries in the Federal District. Initially, identifies the concept of electronic book, its most common formats and the devices and programs used for their reading. Then identifies and analyzes the existing models of acquisition of electronic books to libraries; and the different sellers, who usually are publishers, aggregators or distributors. The selection of models available for libraries are analyzed, of which the most common are by title, per package or approval plan. These business models include the perpetual access, the subscription, the short-term loan and the patron driven acquisition. Highlights aspects related to the licensing of electronic books and the need for a policy of renewal and cancellation of subscriptions; also focuses on copyright and the digital rights management, as well as the experiences of other libraries in dealing with electronic books. Finally, the methodology is described.
\end{abstract}

Keyword: Collection development. Digital library. Electronic book. Library acquisition. 


\section{LISTA DE TABELAS}

Tabela 1 - Bibliotecas do DF

LISTA DE GRÁFICOS

Gráfico 1 - Total de bibliotecas encontradas

Gráfico 2 - Bibliotecas que têm livros eletrônicos

Gráfico 3 - Bibliotecas compraram livros eletrônicos 


\section{LISTA DE QUADROS}

Quadro 1 - Diferenças na compra de livros impressos e eletrônicos $\quad 37$

Quadro 2 - Comparação dos modelos de seleção 44

Quadro 3 - Plataformas $\quad 47$

Quadro 4-Modelos de negócios $\quad 50$

Quadro 5 - Respostas dos e-mails

Quadro 6 - Bibliotecas que desistiram de comprar livros eletrônicos 77

$\begin{array}{ll}\text { Quadro } 7 \text { - Universo da pesquisa } & 78\end{array}$

$\begin{array}{ll}\text { Quadro 8 - Tamanho das bibliotecas } & 78\end{array}$

Quadro 9 - Organização do formulário de entrevista $\quad 80$

Quadro 10 - Dados das bibliotecas $\quad 87$

Quadro 11 - Diferenças entre a compra de livros impressos e eletrônicos 89

Quadro 12 - Diferenças na compra de livros impressos e eletrônicos II 91

Quadro 13 - Motivo para a compra de livros eletrônicos 92

Quadro 14 - Escolha do vendedor/fornecedor $\quad 94$

Quadro 15 - Vendedores de livros eletrônicos 96

Quadro 16 - Critérios levados em conta na hora da compra 101

Quadro 17 - Período de teste 102

Quadro 18 - Formatos dos livros eletrônicos $\quad 104$

Quadro 19 - Suporte técnico 107

Quadro 20 - Treinamento 109

Quadro 21 - Material de apoio para treinamento $\quad 110$

Quadro 22 - Estatísticas de uso $\quad 111$

Quadro 23 - Critérios de renovação e cancelamento 113

Quadro 24 - Modelos de negócio dos vendedores $\quad 114$

Quadro 25 - Motivo para escolha dos modelos $\quad 115$

Quadro 26 - Limite de acessos simultâneos à plataforma 118

Quadro 27 - Modelo de acesso $\quad 119$

Quadro 28 - Modelo de seleção $\quad 120$

Quadro 29 - O valor do pacote compensa os títulos não desejados? 124

Quadro 30 - Atualização automática das edições $\quad 126$

Quadro 31 - Acesso às edições anteriores $\quad 127$

Quadro 32 - Integração dos livros eletrônicos com o catálogo 132

Quadro 33 - Programas para ler os livros eletrônicos 134

Quadro 34 - Acesso ao livro eletrônico 135

Quadro 35 - Forma de acesso aos livros eletrônicos 136

Quadro 36 - Período de empréstimo 137

Quadro 37 - Formas de acesso local aos livros 138

Quadro 38 - Formas de acesso remoto aos livros 139

Quadro 39 - Dispositivos para leitura dos livros eletrônicos $\quad 140$

Quadro 40 - A interface tem opção de navegação em português? 141

Quadro 41 - Busca no texto completo $\quad 142$ 
Quadro 42 - Funcionalidades da plataforma 143

Quadro 43 -É possível copiar e imprimir conteúdo? 144

Quadro 44 - Responsável pela negociação com os vendedores $\quad 145$

Quadro 45 - Acesso e utilização na licença 146

Quadro 46 - Usuários autorizados a acessar e utilizar no contrato 147

Quadro 47 - DRM e restrições do contrato 148

Quadro 48 - O que o serviço contratado inclui 149

Quadro 49 - Direitos da biblioteca $\quad 150$

Quadro 50 - Uso impróprio dos livros eletrônicos pelos usuários $\quad 151$

Quadro 51 - Responsável pelo armazenamento e preservação dos arquivos no contrato 153

Quadro 52 - Garantia de acesso ao material $\quad 154$

Quadro 53 - Cópias dos livros no encerramento da plataforma 156

Quadro 54 - Principais dificuldades legais encontradas para a compra 157

Quadro 55 - Os modelos de negócios classificados de acordo com a literatura 162

Quadro 56 - Funcionamento dos modelos de negócios 164 


\section{LISTA DE SIGLAS}

ACLS American Council of Learned Societies

ALA American Library Association

AZW Amazon Kindle Ebook File

BCE/UnB Biblioteca Central da Universidade de Brasília

CBBD Congresso Brasileiro de Biblioteconomia, Documentação e Ciência da Informação

CBL Câmara Brasileira do Livro

CD-ROM Compact Disc Read-Only Memory

CILIP Chartered Institute of Library and Information Professionals

CSS3 Cascading Style Sheet 3

DDA Demand-Driven Acquisition

DF Distrito Federal

DRM Digital Rights Management

DVD Digital Versatile Disc

EBL Ebook Library

EBLIDA European Bureau of Library, Information and Documentation Associations

EPUB Electronic Publication

ERIC Education Resources Information Center

GDD Gestão de Direitos Digitais

GWT Google Web Toolkit

HD Hard Disk

HTML HyperText Markup Language

IBICT Instituto Brasileiro de Informação em Ciência e Tecnologia

IDPF International Digital Publishing Forum

IFLA International Federation of Library Associations and Institutions

KF8 Kindle Format 8

LOCKSS Lots of Copies Keep Stuff Safe

MARC Machine Readable Cataloging

NISO National Information Standards Organization

OMPI Organização Mundial de Propriedade Intelectual

OS X Operating System Ten

PDA Patron-Driven Acquisition

PDF Portable Document Format 
PL Projeto de lei

RBIC Red de Bibliotecas del Instituto Cervantes

RTF Rich Text Format

SNBU Seminário Nacional de Bibliotecas Universitárias

TLIB Treaty Proposal on Copyright Exceptions and Limitations for Libraries and Archives XML Extensible Markup Language 
1 INTRODUÇÃO

$\begin{array}{ll}\text { 1.1 PROBLEMA } & 16\end{array}$

$\begin{array}{lr}1.2 \text { JUSTIFICATIVA } & 17\end{array}$

$\begin{array}{lr}1.3 \text { OBJETIVO } & 17\end{array}$

2 REVISÃO DE LITERATURA

\begin{tabular}{l}
2.1 CONCEITO DE LIVRO ELETRÔNICO \\
\hline
\end{tabular}

2.2 FORMATOS DOS LIVROS ELETRÔNICOS 24

2.3 APARELHOS PARA LER OS LIVROS ELETRÔNICOS 27

$\begin{array}{lr}\text { 2.3.1 Aparelho leitor de livro eletrônico } & 27\end{array}$

$\begin{array}{lr}\text { 2.3.2 Tablet } & 28\end{array}$

$\begin{array}{lr}\text { 2.3.3 Computador/Notebook } & 29\end{array}$

$\begin{array}{lr}\text { 2.3.4 Smartphone } & 29\end{array}$

2.4 PROGRAMAS PARA LER OS LIVROS ELETRÔNICOS $\quad 30$

$\begin{array}{lr}\text { 2.4.1 Adobe Digital Editions } & 30\end{array}$

\begin{tabular}{lr} 
2.4.2 iBooks & 31 \\
\hline 2.4 .3 Kindle & 31
\end{tabular}

\begin{tabular}{lr} 
2.4.3 Kindle & 31 \\
\hline
\end{tabular}

\begin{tabular}{lr} 
2.4.4 Google Play Livros & 31 \\
\hline
\end{tabular}

$\begin{array}{ll}\text { 2.4.5 Calibre } & 32\end{array}$

$\begin{array}{ll}2.5 \text { AQUISIÇÃO ELETRÔNICA } & 32\end{array}$

$\begin{array}{ll}\text { 2.5.1 Comércio do livro eletrônico } & 32\end{array}$

$\begin{array}{ll}\text { 2.5.2 Desenvolvimento de coleções eletrônicas } & 34\end{array}$

2.6 MODELOS DE COMERCIALIZAÇÃO DE LIVROS ELETRÔNICOS PARA BIBLIOTECAS 37

$\begin{array}{ll}\text { 2.6.1 Vendedores de livros eletrônicos } & 38\end{array}$

$\begin{array}{lr}2.6 .1 .1 \text { Editora } & 39\end{array}$

$\begin{array}{lr}\text { 2.6.1.2 Agregador } & 41\end{array}$

$\begin{array}{ll}\text { 2.6.1.3 Distribuidor } & 42\end{array}$

$\begin{array}{ll}\text { 2.6.2 Modelos de seleção } & 43\end{array}$

$\begin{array}{ll}\text { 2.6.3 Modelos de negócio } & 45\end{array}$

2.6.3.1 Acesso perpétuo $\quad 46$

$\begin{array}{ll}2.6 .3 .2 \text { Assinatura } & 48\end{array}$

$\begin{array}{ll}\text { 2.6.3.3 Empréstimo de curto prazo } & 50\end{array}$

$\begin{array}{ll}\text { 2.6.3.4 Aquisição orientada pelo usuário } & 51\end{array}$

$\begin{array}{lr}\text { 2.6.4 Modelo de acesso } & 52\end{array}$

$\begin{array}{ll}\text { 2.6.4.1 Um por vez } & 53\end{array}$

$\begin{array}{ll}\text { 2.6.4.2 Usuários múltiplos } & 53\end{array}$

$\begin{array}{ll}\text { 2.6.4.3 Número ilimitado de usuários } & 53\end{array}$

$\begin{array}{lr}\text { 2.6.5 Meio de acesso e uso } & 53\end{array}$

$\begin{array}{lr}\text { 2.6.6 Licença de venda } & 54\end{array}$

$\begin{array}{ll}\text { 2.6.7 Renovação e cancelamento } & 56\end{array}$

$\begin{array}{lr}\text { 2.6.8 Modelos inovadores } & 57\end{array}$

$\begin{array}{lr}2.7 \text { DIREITOS AUTORAIS } & 59\end{array}$

2.8 EXPERIÊNCIAS DE OUTRAS BIBLIOTECAS COM LIVROS ELETRÔNICOS 62

2.9 CONCLUSÕES DA REVISÃO DE LITERATURA 63 
3.1 UNIVERSO E AMOSTRA DA PESQUISA

3.1.1 Pré-teste

3.2 FORMULÁRIO DA ENTREVISTA

4 ANÁLISE DE DADOS $\quad 86$

5 CONCLUSÃO

6 REFERÊNCIAS BIBLIGRÁFICAS 166

APENNDICE A - EMPRESAS E ORGANIZAÇÕES CITADAS NO TRABALHO 172

APÊNDICE B - PRIMEIRA VERSÃO DO FORMULÁRIO DA ENTREVISTA 174

APÊNDICE C - SEGUNDA VERSÃO DO FORMULÁRIO DA ENTREVISTA 179

APÊNDICE D - AUTORIZAÇÃO PARA GRAVAÇÃO 184

APÊNDICE E - LISTA DAS BIBLIOTECAS 185 


\section{INTRODUÇÃO}

O livro eletrônico é uma tecnologia que surgiu em 1971, quando o professor norteamericano Michael Hart deu início ao Projeto Gutenberg. No Brasil a temática vem merecendo destaque nos últimos anos, a saber: existe um evento dedicado especialmente a ele no Brasil (desde 2010, Congresso Internacional CBL do Livro Digital) e ele está sendo discutido em uma proposta de lei na Câmara dos Deputados (PL 4.534/2012).

O projeto de lei 4.534/2012, que está em tramitação na Câmara dos Deputados, busca alterar a lei 10.753/2003 que institui a Política Nacional do Livro, para atualizar a definição de livro e para alterar a lista de equiparados a livro. Esse projeto pretende equiparar tanto o livro digital quanto o dispositivo de leitura de livros eletrônicos ao livro impresso para que sua importação seja isenta de impostos, já que ele é taxado por ser um aparelho eletrônico. O relatório da Deputada Fátima Bezerra julga que apenas os livros eletrônicos, e não os aparelhos de leitura, devem ser equiparados ao livro. Entretanto, os votos dos Deputados Onyx Lorenzoni e Marcelo Almeida defendem que por esse ser um aparelho destinado apenas para a leitura de livros, que não permite a navegação na Internet, e que tem um custo menor que os tablets, a isenção de impostos desses aparelhos ajudaria a promover a disseminação do hábito da leitura. O projeto segue em tramitação na Câmara, e foi enviado da Comissão de Cultura para a Comissão de Constituição e Justiça e de Cidadania, onde se encontrava no dia 09 de novembro de 2015 .

No âmbito do Distrito Federal, entrou em vigor a Lei 5.420 de 24 de novembro de 2014 que instituiu a Biblioteca Digital da Rede Pública de Ensino do DF. De acordo com essa lei a Biblioteca Digital deverá conter além de livros, aulas, jogos e exercícios, entre outros materiais para complementar o ensino.

Segundo a International Federation of Library Associations and Institutions (IFLA, 2014), a venda de livros eletrônicos cresceu de maneira significativa na América do Sul. Entretanto, no final de 2015, as notícias sobre os livros eletrônicos são de que o seu ritmo de crescimento diminuiu, e o que se vê é um cenário híbrido (A VOZ DA SERRA, 2015; ALTARES, 2015; MENDONÇA, 2015).

As bibliotecas que estão atentas às novas tecnologias buscam a melhor maneira de oferecer os livros eletrônicos para seus usuários. Entretanto, a comercialização de livros eletrônicos para bibliotecas é diferente tanto da venda desses mesmos livros eletrônicos para pessoas físicas quanto da venda de livros impressos para bibliotecas. 
Como destaca Konrad (2013), a compra de livros eletrônicos pode ser complicada, exigindo muito tempo e recursos. Os modelos de negócios para bibliotecas são complexos e os vendedores impõem muitas limitações como, por exemplo, limites ao número de acessos simultâneos, preços elevados, restrições de espaço físico para acesso ao conteúdo digital, entre outros.

Além disso, muitas dúvidas podem surgir no momento da escolha dos editores, com suas respectivas plataformas e modelos de negócios disponíveis no mercado. Com a crescente demanda por livros eletrônicos também aumenta o número de editores envolvidos na sua produção, criando, entre outros, uma diversidade de plataformas, modelos de compra, preços etc. Urge, portanto, a busca por um mínimo de padronização tecnológica, similar ao conseguido décadas atrás com as fitas cassetes e vídeos - este aspecto pode ser um obstáculo para a maior penetração do livro eletrônico na sociedade atual.

Muitas editoras têm receio em relação à venda de livros eletrônicos: outras, entretanto, já viram nesta tecnologia uma nova oportunidade de negócios e se aproveitam ao máximo disso, inclusive tentando replicar as características negociais dos livros impressos no contexto dos eletrônicos, contradizendo os benefícios da tecnologia (AMERICAN LIBRARY ASSOCIATION, 2012).

Dentre os benefícios inerentes ao livro eletrônico é possível destacar as possibilidades de acesso fora da área física da biblioteca, de se obter esse acesso mesmo quando a biblioteca está fechada, de atualização constante dos livros, a inclusão de vídeos e links, além da falta do desgaste decorrente do uso desse material (DOUCETTE; LEWONTIN, 2012). Por isso, segundo Morris e Sibert (2011, p. 98), os "vendedores e editoras se esforçam para encontrar modelos de compra que sejam interessantes para a biblioteca e que, ao mesmo tempo, protejam o conteúdo da pirataria e que gerem ou pelo menos protejam o 'lucro"'.

Sobre a relação entre bibliotecas e vendedores, Minčić-Obradović (2011, p. 27, apud KONRAD, 2013, p. 11, tradução nossa) observou uma conturbada relação entre bibliotecas e editores ao comentar que:

As bibliotecas argumentam que a indústria do livro eletrônico é conduzida pela vontade das editoras e que as editoras têm sido conservadoras na transição para o mercado de livros eletrônicos e nos seus modelos de negócios. Por outro lado, as editoras acusam os bibliotecários de não serem proativos e de ficarem sentados esperando o que vai acontecer.

Para que os bibliotecários tenham maior liberdade de ação é importante que conheçam o mercado dos livros eletrônicos. Isso lhes dará maior poder no momento da negociação, permitindo que façam as exigências necessárias e proponham novos modelos de negócios que 
favoreçam a biblioteca e os usuários. As bibliotecas e fornecedores de livros eletrônicos devem trabalhar juntos para alcançar um acordo no qual todo o potencial dos livros eletrônicos possa ser explorado. A falta de resolução de problemas e desafios atuais pode ameaçar a qualidade do serviço oferecido pelas bibliotecas aos seus usuários, o que pode ameaçar o futuro das negociações com bibliotecas (VASILEIOU; ROWLEY; HARTLEY, 2012).

A American Library Association (ALA), em 2012, já se declarou sobre o assunto em um documento intitulado "Ebook Business Models for Public Libraries” (Modelos de negócios de livros eletrônicos para bibliotecas públicas). Já no primeiro parágrafo desse documento merece destaque a pressão feita pelos bibliotecários para que a ALA influencie as grandes editoras a venderem livros eletrônicos para bibliotecas com condições mais razoáveis:

Em resposta às preocupações urgentes dos membros, o grupo de trabalho de
conteúdo digital e bibliotecas da American Library Association (ALA), em
colaboração com o Presidente e o Diretor Executivo da ALA, voltou seus
esforços para influenciar as maiores editoras ("Big 6") a vender livros
eletrônicos para as bibliotecas em condições razoáveis (AMERICAN
LIBRARY ASSOCIATION, 2012, p. 1, tradução nossa).

Alguns exemplos das condições impostas na venda de livros eletrônicos para bibliotecas que constam nesse documento são: número de empréstimos limitado a um usuário de cada vez, limite para a quantidade de empréstimos de cada exemplar, grande variação nos preços, venda às bibliotecas apenas certo tempo depois da venda para o público, retirada do livro apenas no espaço físico da biblioteca, restrições a consórcios e empréstimos entre bibliotecas. Além disso, alguns editores se recusam a vender para bibliotecas, independentemente das condições (AMERICAN LIBRARY ASSOCIATION, 2012).

Um exemplo de uma iniciativa que busca melhorar a comunicação entre bibliotecas e vendedores é o projeto 10 x 10 da Rede de Bibliotecas Públicas da Catalunha, região localizada no nordeste da Espanha, que promove o diálogo direto entre editoras e bibliotecários. Nesses encontros as editoras podem explicar para os bibliotecários a sua linha editorial e a sua filosofia. Além disso, as editoras podem conhecer as preocupações das bibliotecas, descobrir como seus livros são recebidos e escutar sugestões (BIBLIOTECAS PÚBLICAS DE CATALUÑA, 2013).

Na Europa, existe também uma campanha do European Bureau of Library, Information and Documentation Associations (EUROPEAN BUREAU OF LIBRARY INFORMATION AND DOCUMENTATION ASSOCIATIONS, 2014) chamada "The right to e-read" ("O direito de ler eletrônico"). Essa campanha pretende alcançar os seguintes objetivos: que a venda de best sellers seja disponibilizada para bibliotecas, que as bibliotecas possam comprar livros eletrônicos a preços justos e com condições de uso razoáveis, que os autores sejam remunerados 
pelo empréstimo dos livros eletrônicos e que todos os cidadãos se beneficiem do empréstimo de livros eletrônicos em bibliotecas. Para isso, eles pedem uma lei clara de propriedade intelectual que permita que as bibliotecas cumpram com a sua missão.

Essas iniciativas comprovam a urgência das bibliotecas em diferentes partes do globo em garantir que elas possam comprar livros eletrônicos por um preço justo e disponibilizá-los para seus usuários.

No Brasil, muitas bibliotecas já adquiriram e muitas outras já planejam comprar livros eletrônicos. Existem no país algumas iniciativas voltadas para o uso de livros eletrônicos em bibliotecas. O site ExtraLibris ${ }^{1}$ oferece o curso online "e-Books para Bibliotecas: uma introdução ao universo dos livros eletrônicos" que apresenta os livros eletrônicos e seus formatos, como eles podem ser acessados, quais são as possibilidades de aquisição, os critérios de avaliação e como deve ser a implantação desse novo suporte nas bibliotecas.

Os profissionais da Ciência da Informação Moreno de Albuquerque Barros e Liliana Giusti Serra também costumam oferecer cursos presenciais, em diferentes cidades, com duração de um ou dois dias, sobre o uso de livros eletrônicos em bibliotecas. Além disso, Liliana Serra já apresentou alguns trabalhos em congressos e já publicou um livro (SERRA, 2014) sobre o assunto. Também podem ser encontrados alguns artigos, monografias, dissertações e trabalhos publicados em congressos de outros autores sobre o assunto.

Apesar disso, a literatura em português sobre livros eletrônicos é escassa e praticamente inexistente quando se trata de modelos de negócios de livros eletrônicos para bibliotecas. Com o crescimento da área cresce também a necessidade por estudos que auxiliem os bibliotecários no processo de compra que é algo novo e único e cujos problemas se repetem por todo o mundo.

Na conclusão de seu artigo, Walters (2013, p. 205, tradução nossa) diz como ele imagina que deve ser o futuro do mercado informacional e das negociações entre bibliotecários e fornecedores de livros digitais:

Primeiro, os bibliotecários devem manter-se informados não apenas sobre novas tecnologias, mas também sobre os contextos legal e econômico nos quais produtos informacionais são desenvolvidos, comercializados e utilizados. Segundo, decisões sobre livros digitais devem ser baseadas em evidências sólidas, especialmente no que se refere à relação custo-benefício. A compilação e avaliação de evidências podem ajudar na tomada de decisões e contribuir para o trabalho da profissão como um todo. Finalmente, os bibliotecários devem estar preparados para ajudar a moldar tendências enquanto elas ocorrem - trabalhar com editores e consórcios para desenvolver e modificar licenças e plataformas para livros digitais de maneira a beneficiar as bibliotecas e os usuários. Apesar de os objetivos dos fornecedores de livros digitais às vezes não serem os mesmos das universidades e faculdades, os

\footnotetext{
${ }^{1}$ URL: www.extralibris.org
} 
bibliotecários estão bem posicionados para dirigir os esforços dos fornecedores. Afinal, clientes - e não vendedores - determinam quais produtos (e sob quais termos de licença) irão triunfar no mercado informacional.

Apesar dos questionamentos que às vezes surgem sobre a permanência e sobrevivência do livro em papel, a maioria das bibliotecas que possuem livros eletrônicos segue um modelo híbrido, onde o digital e o papel convivem em harmonia. Entretanto, existem algumas exceções, como a Bibliotech, no Texas ${ }^{2}$ e a recém-inaugurada biblioteca da Universidade Politécnica da Flórida, que são exclusivamente digitais.

É importante ressaltar que o foco desta pesquisa está nos problemas relacionados aos livros que serão comprados pelas bibliotecas e que possuem direitos autorais. Existem, entretanto, outros meios de inserção dos livros eletrônicos no acervo, por exemplo, no caso de livros de domínio público, de material produzido pela própria instituição e de livros disponibilizados de forma gratuita e legal na rede por meio de uma licença aberta, muitas vezes por interesse dos próprios autores. A disponibilização desse tipo de material não se torna ilegal só porque não houve uma compra, e é uma das novas possibilidades criadas pelo mundo digital. A inserção e distribuição desse material necessitam de atenção especial e exigem métodos próprios ao tratamento de informação digital. Entretanto, várias ideias e conceitos se aplicam a todos os livros digitais, independentemente de sua propriedade.

\subsection{PROBLEMA}

Surge nas bibliotecas o interesse pela aquisição de livros eletrônicos para oferecer mais uma possibilidade de acesso à informação aos usuários, que já compram seus próprios livros eletrônicos e querem vê-los também na sua biblioteca. Mas esse é um formato novo para as bibliotecas e que traz também novas características de compra, gerenciamento e disponibilização. Os modelos de negócios oferecidos pelos vendedores são complexos e variados, dificultando o entendimento das bibliotecas sobre o produto a ser comprado.

O assunto já é amplamente abordado na literatura estrangeira, mas por enquanto muito pouco foi dito sobre ele no Brasil. Este trabalho busca, mais especificamente, analisar a realidade do Distrito Federal (DF), por limitações geográficas da pesquisa. O DF é uma região com características peculiares, pois reúne muitos órgãos públicos de abrangência nacional em

\footnotetext{
2 URL: http://bexarbibliotech.org/
} 
uma única área, e por isso é dificilmente comparado a outra parte do país. Aqui se encontram também muitas bibliotecas de universidades particulares e de importantes órgãos internacionais de cultura.

Por isso, a pergunta de pesquisa que motivou este trabalho foi:

Quais são os modelos de negócios utilizados para a aquisição de livros eletrônicos pelas bibliotecas do DF?

\subsection{JUSTIFICATIVA}

Esta é uma pesquisa científica já que se propõe a contribuir para a ciência e será realizada de acordo com o método científico (BHATTACHERJEE, 2012). A proposta parte de uma teoria que será testada a partir de observação, e tem como base outros trabalhos científicos feitos anteriormente sobre o mesmo tema. É possível observar na literatura a preocupação de alguns cientistas como Polanka (2012), Price (2011), Kaplan (2012), Vasileiou, Rowley e Hartley (2012) e Roncevic (2013), entre outros, com a aquisição de livros eletrônicos pelas bibliotecas já que essa compra difere muito da compra de livros em papel.

A pouca quantidade de informações sobre o assunto publicada no Brasil, a atualidade e a crescente importância do tema justificam a realização da pesquisa do ponto de vista teórico. Esse é um assunto ainda pouco estudado no Brasil, mas que já anuncia um grande crescimento. Por isso é importante recolher mais informações sobre o assunto, para que ele tenha uma maior base teórica que viabilize sua aplicação prática.

A pesquisa se justifica pelo ponto de vista prático/aplicado já que visa a auxiliar a tomada de decisão dos profissionais da área que engloba, quando envolvidos num problema a ela relacionado.

\subsection{OBJETIVO}

O objetivo geral desta pesquisa é:

Identificar os modelos de comercialização utilizados para a aquisição de livros eletrônicos para bibliotecas do DF.

Os objetivos específicos são: 
1) Identificar os principais termos relacionados aos livros eletrônicos, bem como suas conceituações.

2) Identificar e analisar os modelos existentes de comercialização de livros eletrônicos para bibliotecas.

3) Identificar as bibliotecas que utilizam o livro eletrônico no DF.

4) Analisar os modelos de negócios utilizados para a aquisição de livros eletrônicos para bibliotecas do DF, bem como as razões dessas escolhas.

O objetivo específico 1 busca conhecer melhor o livro eletrônico e o seu contexto, trazendo a definição de conceitos importantes que serão úteis para a realização de uma boa compra. É importante conhecer o que se vai adquirir para poder escolher o que é melhor para os usuários e para fazer exigências ao vendedor. $\mathrm{O}$ conhecimento do produto aumenta o poder de negociação dos bibliotecários. O entendimento dos conceitos que envolvem o livro facilita a compreensão dos modelos de comercialização, e por isso é essencial nesse trabalho.

O objetivo específico 2 busca trazer o que foi dito pela literatura sobre a comercialização de livros eletrônicos. Essa informação será a base para a análise do que acontece nas bibliotecas do Distrito Federal.

Os objetivos específicos 1 e 2 serão respondidos pela revisão de literatura.

O objetivo específico 3 busca viabilizar a realização das entrevistas já que primeiro é necessário identificar quais bibliotecas fazem parte do universo da pesquisa. Esse objetivo será alcançado pela pesquisa por e-mail.

O objetivo específico 4 é o último e será alcançado através da análise dos dados obtidos com as entrevistas. 


\section{REVISÃO DE LITERATURA}

A revisão de literatura foi feita no período de março de 2014 a março de 2015. As fontes utilizadas para pesquisa foram o portal de periódicos da Capes, a bibliografia do curso online "e-Books para Bibliotecas: uma introdução ao universo dos livros eletrônicos" oferecido pelo site ExtraLibris, a busca integrada do site da Biblioteca Central da Universidade de Brasília (BCE/UnB), o repositório institucional da BCE/UnB, a Biblioteca Digital de Teses e Dissertações do Instituto Brasileiro de Informação em Ciência e Tecnologia (IBICT), a base Ebrary assinada pela BCE/UnB, o Google Acadêmico, o sistema de alertas do Google, a base de dados Education Resources Information Center (ERIC), a base de dados Science Direct, os Anais do Congresso Brasileiro de Biblioteconomia, Documentação e Ciência da Informação (CBBD) de 2013 e 2011 e os Anais do Seminário Nacional de Bibliotecas Universitárias (SNBU) de 2008, 2010, 2012 e 2014.

Para a estratégia de busca foram utilizados os termos "ebook", "e-book", "electronic book", "digital book", "livro eletrônico", "livro digital", "libro electronico" e "libro digital". Buscou-se utilizar todas as variações dos termos para que a recuperação fosse mais completa já que tais termos ainda não estão consolidados e todas as formas aparecem em textos diferentes

$\mathrm{Na}$ revisão de literatura serão definidos os conceitos importantes para a compreensão do trabalho. Ela também apresentará resultados de estudos ligados ao que será realizado, além de proporcionar uma estrutura para estabelecer a importância do estudo e uma referência para comparação dos resultados (CRESWELL, 2010).

\subsection{CONCEITO DE LIVRO ELETRÔNICO}

Kaplan (2012) diz que o mercado de livros que não são impressos teve início com a criação do livro em áudio por iniciativa do Congresso Americano que criou o Talking Book Program em 1931, em parceria com a American Foundation for the Blind. Nos anos 1960 e 1970, com o surgimento das fitas cassete, as bibliotecas passaram a oferecer livros em formatos diferentes do papel.

Martínez de Sousa (2010) afirma que o audiolivro surgiu aproximadamente em 1970 no Reino Unido e que ele não é uma nova forma de livro, mas apenas uma forma diferente de apresentar o conteúdo. $\mathrm{O}$ audiolivro seria útil apenas para obras curtas, de cunho narrativo ou poético, já que não teria sentido escutar fórmulas matemáticas. 
Robert Darton (2010) considera que o primeiro livro eletrônico foi projetado em 1945, que é quando foi apresentada a ideia do Memex de Vannevar Bush. Entretanto, Bush apenas imaginou algo que ainda não poderia ser construído com a tecnologia de sua época e que por isso existiu naquele momento apenas na sua imaginação.

De acordo com Hart (1992 apud KOH; HERRING, 2014), Ardito (2000), Vassiliou e Rowley (2008) e Kaplan (2012) o livro eletrônico, tal qual como é conhecido hoje, surgiu em 1971, com o Projeto Gutenberg de Michael Hart, na Universidade de Illinois, nos Estados Unidos. O projeto teve início com a Declaração da Independência dos Estados Unidos e existe até hoje, contando com um acervo de 47.193 livros em novembro de 2014 (PROJECT GUTENBERG, 2014).

Apesar de ter surgido em 1971, o livro eletrônico ainda suscita muitas questões quanto à sua definiçãa, sobre o que realmente pode ou não ser chamado de livro eletrônico e também sobre a sua nomenclatura, já que no Brasil ele também é conhecido pelo seu nome em inglês (e-book) e também é chamado de livro digital.

Em inglês tampouco existe um consenso já que os termos e-book, electronic book e digital book são utilizados quando se quer falar do texto eletrônico em meio digital, do programa para leitura ou do aparelho utilizado para ler o referido livro (KOH; HERRING, 2014; MARTÍNEZ DE SOUSA, 2010).

Essa confusão de termos é destacada na definição de Pinheiro (2011, p.14):

[...] designa uma publicação em formato digital que, para além do texto, pode incluir também imagens, vídeo e áudio. Outras designações são livro digital ou livro digitalizado. Muitas vezes utiliza-se, erradamente, o termo ebook para designar um $e$-reader.

Martínez de Sousa (2010) defende que o termo livro eletrônico deve ser utilizado para a obra enquanto o dispositivo de leitura onde se armazenam os livros deve ser chamado de leitor, leitor eletrônico, aparelho leitor, dispositivo de leitura, dispositivo portátil ou suporte. Em conformidade com o que defende esse autor, no presente trabalho o termo livro eletrônico será utilizado para se referir apenas ao texto, à obra intelectual, e não ao seu suporte.

A criação do termo livro eletrônico ("electronic book") é atribuída ao professor Andries Van Dam, da Brown University. Ele recebeu essa denominação em 1968, quando Van Dam trabalhava nos primeiros sistemas de hipertexto (ARDITO, 2000; REILLY, 2003 apud KOH; HERRING, 2014).

Para a presente pesquisa foi escolhido o uso do termo livro eletrônico por estar em língua portuguesa e por ser o termo preferido pelo Dicionário de Biblioteconomia e Arquivologia de 
Cunha e Cavalcanti (2008). De acordo com esse dicionário livro eletrônico é um livro que "foi convertido ao formato digital, ou originalmente produzido nesse formato, para ser lido em computador ou dispositivo especial destinado a esse fim" (CUNHA; CAVALCANTI, 2008, p. 233).

A definição de livro eletrônico de Armstrong et al. (2002, p. 217 apud VASSILIOU; ROWLEY, 2008, tradução nossa) é amplamente aceita: “ [...] texto eletrônico de qualquer tamanho ou estrutura (objeto digital, com exceção de periódicos) que é disponibilizado em meio eletrônico ou ótico para qualquer dispositivo (portátil ou não) que possua uma tela".

A definição da International Encyclopedia of Information and Library Science, de 2003, diz que:

O resultado da combinação da estrutura clássica do livro, ou do conceito familiar de livro, com características que podem ser oferecidas em um ambiente eletrônico pode ser chamado de livro eletrônico, que é projetado como um documento interativo que pode ser criado ou lido em um computador (LANDONI, 2003, p. 168 apud VASSILIOU; ROWLEY, 2008, p. 2, tradução nossa).

O dicionário para bibliotecas e sistemas de informação da National Information Standards Organization (NISO) define os livros eletrônicos como:

[...] documentos digitais, licenciados ou não, onde prevalece o texto pesquisável, análogos ao livro impresso (monografia). O uso dos livros eletrônicos muitas vezes depende de um dispositivo próprio e/ou de um programa especial para leitura ou visualização (NISO, 2005 apud VASSILIOU; ROWLEY, 2008, p. 2, tradução nossa).

As definições da NISO e da International Encyclopedia of Information and Library Science levam em conta o livro impresso para definir o livro eletrônico. Apesar de existirem muitas diferenças entre os formatos, os livros eletrônicos foram criados com base nos livros em papel e muitos buscam manter a sua essência intacta. Exemplo disso são os aparelhos para leitura de livros eletrônicos, que desenvolveram uma tecnologia, conhecida como papel eletrônico, que faz com que a tela pareça uma folha de papel impresso.

Os livros eletrônicos costumam manter a aparência e a organização de um livro impresso, com capa, sumário, divisão em capítulos além de outras características (BARROS, 2014). Entretanto, alguns elementos, como os índices remissivos, podem ser ocultados já que é possível pesquisar diretamente em todo o texto (REIS; ROZADOS, 2014). Portanto a maior diferença entre um livro impresso e um eletrônico está no suporte. Um livro eletrônico pode aparecer com diferentes conteúdos, inclusive multimídia, como é sugerido na definição de Pinheiro (2011), e pode vir em diferentes formatos (por ex.: PDF, EPUB etc.), mas ele é caracterizado principalmente por ser um livro e não qualquer outra coisa. 
A definição de Velloso (2012 apud REIS; ROZADOS, 2014) também traz essa ideia:

Primeiro, o e-book constitui uma espécie do gênero livro, que não se singulariza pelo seu conteúdo, mas pela sua forma. É a versão digital dos tradicionais livros impressos, que pode ser adquirida em meio físico (sobretudo em CDs) ou digital, mediante download do seu conteúdo.

Vassiliou e Rowley (2008) propõem uma nova definição para livro eletrônico na conclusão de seu artigo. Essa definição é dividida em duas partes para exprimir tanto as características permanentes dos livros eletrônicos quanto a sua natureza dinâmica, guiada pelas tecnologias em constante mudança pelas quais eles são oferecidos e lidos. A definição de livro eletrônico de Vassiliou e Rowley diz que:

(1) Um livro eletrônico é um objeto digital com conteúdo textual e/ou de outro tipo, e surge como resultado da combinação do conceito familiar de livro com características que podem ser oferecidas em um ambiente eletrônico. (2) Os livros eletrônicos normalmente possuem recursos próprios de uso como funções de pesquisa e referência cruzada, links de hipertexto, marcadores, anotações, destaques no texto, objetos multimídia e ferramentas interativas (VASSILIOU; ROWLEY, 2008, p. 9, tradução nossa).

De acordo com a IFLA (2014) o livro eletrônico é a versão digital de um trabalho textual que está disponível publicamente (de forma paga ou gratuita) como um trabalho separado. Merece destaque o fato que versões digitais em áudio de trabalhos textuais podem ser consideradas como livros eletrônicos, enquanto as versões digitais de jornais e periódicos não são consideradas como livros.

A definição de livro eletrônico da IFLA (2014) é acompanhada por uma série de acepções para esclarecer o que pode ou não ser chamado de livro eletrônico, devido à complexidade desse objeto. De acordo com a IFLA (2014) o livro eletrônico pode:

- pertencer a um indivíduo ou à biblioteca, mas ele é normalmente licenciado por um editor ou vendedor;

- estar contido em uma coleção ou pacote de livros que são comercializados como um todo;

- ser aumentado ou suplementado por elementos audiovisuais ou de outro tipo, como por exemplo dados de GPS como parte do arquivo ou por links para arquivos diferentes;

- coexistir com a versão impressa em papel do mesmo texto ou não possuir nenhum equivalente físico;

- permitir que seja feito o seu download para um dispositivo ou ser transmitido por streaming, o que exige uma conexão com a Internet sempre que o trabalho é acessado; 
- ser produzido por uma editora ou auto publicado pelo autor para o público leitor (que são as possibilidades mais comuns), mas também pode ser uma monografia profissional ou acadêmica publicada por entidades tais como editoras universitárias ou organizações profissionais.

A definição da IFLA é bem completa por conter também os esclarecimentos adicionais, que ajudam a identificar não só o que é um livro eletrônico, mas também de onde ele surge e como ele pode ser consumido.

É possível perceber que a IFLA (2014) e Martínez de Sousa (2010) possuem opiniões divergentes no que se refere ao audiolivro e se ele pode ou não ser considerado como um livro eletrônico, apesar de ser uma tecnologia consolidada e amplamente utilizada em alguns países. Se o audiolivro já era reconhecido como livro antes da chegada do livro eletrônico, não há por que desconsiderá-lo como livro, até porque ele se encaixa nas definições de Landoni (2003 apud Vassiliou e Rowley, 2008) e de Vassiliou e Rowley (2008).

Sobre o que pode ser chamado ou não de livro eletrônico os limites ainda não são claros como os do livro impresso, que são facilmente identificados sejam eles para adultos ou para crianças, com ou sem ilustrações, ou até mesmo com efeitos tridimensionais como 3D ou com рор-ир.

Existem arquivos de vários formatos e com muitas características diferentes que são chamados de livros eletrônicos. Alguns possuem apenas a imagem do livro impresso (sem caracteres legíveis), outros que possuem apenas o texto, alguns com capa e sumário e outros que parecem jogos, que podem possuir partes para leitura, mas que também permitem a interação do leitor.

Os arquivos eletrônicos que possuem apenas a imagem do livro impresso digitalizada com uso de um aparelho de escaneamento, que não possuem caracteres legíveis, possuem texto não pesquisável, e tampouco possuem outras funções inerentes ao livro eletrônico como referência cruzada, links de hipertexto, marcadores, anotações, entre outras, não devem ser chamados de livros eletrônicos de acordo com as definições da NISO e de Vassiliou e Rowley (2008).

Outras questões polêmicas em relação ao livro eletrônico incluem a extensão do arquivo digital e a maneira como ele é apresentado. Há quem defenda que não são livros eletrônicos aqueles que são apresentados em formato PDF, já que esse é um formato rígido diferente do EPUB, que foi criado para a leitura de textos e que permite que o leitor modifique a fonte, o tamanho das letras, o tamanho das bordas, entre outras coisas, no momento da leitura. 


\subsection{FORMATOS DOS LIVROS ELETRÔNICOS}

O formato de arquivo é a "especificação de regras e padrões descritos formalmente para interpretação das cadeias de bits que formam os arquivos digitais" (TOUTAIN, 2006, p. 17). O formato de arquivo é a tecnologia usada para a sua criação que vai determinar a sua extensão (.txt, .pdf, .epub), as funcionalidades (texto ajustável ou fixo, inclusão de gráficos e tabelas) e a sua compatibilidade com os programas contidos nos aparelhos utilizados para leitura.

Os formatos de arquivos são classificados em abertos, quando suas especificações são de conhecimento público, em fechados quando as especificações não são divulgadas pelos proprietários, em proprietários quando uma organização detém os seus direitos e em padronizados quando são produzidos por órgão de normalização (TOUTAIN, 2006).

Não existe um formato único para os arquivos digitais que contém os livros eletrônicos. Os formatos de arquivo mais comuns para os livros eletrônicos são PDF e EPUB, mas também existem o MOBI, o AZW, o KF8, o HTML e o RTF. A seguir se tratará de cada um separadamente.

\section{- PDF (Portable Document Format)}

O formato PDF é um padrão aberto que conserva a formatação do documento (tipo e tamanho da fonte, espaçamento, cores, imagens, gráficos etc.) independente da sua plataforma de criação ou leitura (LEBERT, 2009 apud BARROS, 2014). Uma característica marcante do PDF é que ele mantém o layout do documento igual à sua versão impressa. O PDF também pode receber uma proteção contra cópias ou que evite a sua impressão (LINS, 2014).

A vantagem desse formato é a sua compatibilidade com vários aparelhos, sejam eles leitores de livros digitais, smatphones, tablets ou computadores de qualquer marca. Outra vantagem do PDF é a facilidade para criação de arquivos nesse formato, que é universal e tradicional (LINS, 2014).

Sua desvantagem é que o texto em formato PDF não se adapta ao tamanho da tela como o texto em EPUB: seu conteúdo é estático, o que significa que não pode ser alterado; o arquivo nesse formato é pesado e por isso ocupa mais espaço de memória; e é difícil transformar arquivos em PDF para outros formatos (LINS, 2014).

Apesar do PDF não ser o formato mais indicado para livros eletrônicos, ele é muito comum devido à sua ampla compatibilidade. 


\section{- EPUB (Electronic Publication)}

O formato EPUB é um padrão internacional aberto que foi criado especialmente para a leitura de livros digitais e é compatível com a maioria dos leitores de livros digitais. O EPUB foi definido pelo International Digital Publishing Forum (IDPF), consórcio de empresas que inclui a Microsoft, a Sony e a Adobe (BARROS, 2014). O EPUB é composto por um arquivo em XML (LINS, 2014) e permite a inclusão de uma proteção por DRM, o que é feito pelo programa Adobe Content Server (DOUCETTE; LEWONTIN, 2012).

As vantagens do EPUB são que ele permite que o leitor modifique vários aspectos do texto no momento da leitura, sem precisar salvar as alterações no arquivo, como o tipo e tamanho da fonte, as margens e o espaçamento entre as linhas, além de permitir que sejam feitas marcações e anotações. Outra vantagem é que esse é um formato universal, e que seu arquivo é simples e leve (LINS, 2014).

Sua desvantagem é que às vezes é necessária a instalação de um programa especialmente para a sua leitura (existem várias opções gratuitas como o Calibre para computadores e o Google Livros para smartphones e tablets com Android. Ver outros na seção 2.4). Outras desvantagens desse formato são: não funciona bem para a visualização de gráficos; a conversão automática de arquivos de outros formatos para EPUB é difícil, pois gera um arquivo com muitos erros; ele não mantém o projeto gráfico original; a formatação é simples e muda de acordo com o leitor, o que faz com que ele não seja indicado para livros de arte e fotografia (LINS, 2014).

Esse formato traz o texto de forma fluida e redimensionável, o que significa que é impossível existir uma identificação fixa das páginas já que "o texto muda de distribuição de acordo com o tamanho da tela em que está sendo apresentado" (TAVARES, 2012 apud BARROS, 2014). Isso pode ser um problema para pesquisadores que necessitam citar a página onde é possível encontrar determinado trecho de um livro.

Para resolver o problema da estruturação do texto surgiu uma evolução desse formato, o EPUB3, que possui layout fixo, mantendo assim páginas e imagens na mesma posição. O EPUB3 também permite a inclusão de fórmulas, tabelas, áudio, vídeo e animações no texto. Infelizmente, esse formato ainda não é amplamente compatível com softwares e dispositivos de leitura (BARROS, 2014). 
- HTML (HyperText Markup Language)

Esse é um formato muito utilizado para a criação de páginas da Internet que pode ser aberto por qualquer navegador de Internet como Internet Explorer, Google Chrome, Safari e Mozilla Firefox (BARROS, 2014). Sua desvantagem é que ele não foi criado para a apresentação de livros eletrônicos, apesar de muitos livros serem disponibilizados nesse formato, e por isso não armazena ou exibe a informação de modo eficiente, já que ocupa muito espaço e possui poucas funcionalidades de formatação de texto (BARROS, 2014).

- $\mathrm{MOBI}$

Esse é um formato proprietário criado pela empresa francesa Mobipocket e possui um software de leitura gratuito que pode ser instalado em computadores com os sistemas Windows, OS X (Apple) e Linux e em dispositivos como Palm, Blackberry, Windows Mobile e Symbian (BARROS, 2014).

- AZW

Esse é um formato proprietário que foi utilizado nas primeiras versões do leitor Kindle, da Amazon. Ele funciona como o EPUB, permitindo que o texto se ajuste ao tamanho da tela (BARROS, 2014).

- $\quad \mathrm{KF8}$ (Kindle Format 8)

Esse é um formato proprietário da Amazon que passou a ser utilizado a partir do lançamento do modelo Kindle Fire, em 2011. Esse novo formato trouxe novas possibilidades para os livros eletrônicos, já que permite a inclusão de vários recursos novos (BARROS, 2014). O KF8 oferece gráficos melhorados e recursos de formatação, além de suportar HTML5 e CSS3 (AMAZON, 2011 apud DOUCETTE; LEWONTIN, 2012).

- $\quad$ RTF (Rich Text Format)

Esse é um formato proprietário da Microsoft que não é muito utilizado e que é incompatível com a maioria dos leitores de livros eletrônicos, apesar de ser compatível com alguns editores de texto do mercado. O programa Microsoft Reader exige a sua conversão para o formato .lit para leitura (BARROS, 2014). Esse formato, assim como o HTML, não foi criado especialmente para a leitura de livros eletrônicos. 


\subsection{APARELHOS PARA LER OS LIVROS ELETRÔNICOS}

Quando se refere ao suporte de um livro isso significa o meio físico onde o livro se encontra e que permite a sua leitura. O livro tradicional existe normalmente no suporte de papel, mas esse suporte já foi também papiro, pergaminho, pedra e tábula de argila. Os livros eletrônicos também necessitam de um suporte que permita a sua leitura, que pode ser um computador, um notebook, um tablet, um e-reader ou um smartphone. E para cada um desses suportes também deve ser utilizado um programa (software) para a leitura desses livros. A seguir serão apresentados os principais suportes e programas.

\subsubsection{Aparelho leitor de livro eletrônico}

Os e-readers são aparelhos especialmente desenvolvidos para a leitura de livros eletrônicos. Eles costumam utilizar a tecnologia de papel eletrônico, também conhecida como papel virtual ou $e$-ink, que imita a aparência da tinta comum no papel. Diferente dos visores que possuem iluminação pela parte de trás da tela, o papel eletrônico reflete a luz como o papel comum, o que torna a leitura mais confortável aos olhos e aumenta o ângulo de visão, além de permitir que o texto seja lido sob o sol, como um papel normal (WIKIPEDIA, 2014c).

Além disso, esses aparelhos também costumam possuir funções que permitem que o leitor controle o tamanho da letra, o tamanho das margens, o espaçamento das linhas, faça marcações e anotações no livro.

O primeiro protótipo de um leitor de livros eletrônicos foi criado em 1968 por Alan Kay (HENKE, 2003, p. 22 apud KOH; HERRING, 2014). Ele era estudante de pós-graduação da Universidade de Utah e desenvolveu o conceito para um leitor de livros eletrônicos que ele chamou de Dynabook. O Dynabook seria um computador portátil e interativo, com um visor de tela plana e comunicação sem fio (ARDITO, 2000).

De acordo com Lambert et al. (2005, p. 84 apud KOH; HERRING, 2014) o primeiro leitor de livros eletrônicos a ser lançado foi o Data Discman da Sony, em 1990. Em 1998 a Gemstar lançou o Rocket e-book, que lembra um livro de papel por seu formato e por suas funções (HENKE, 2003 apud KOH; HERRING, 2014). O Rocket e-book podia armazenar de 4 até 360 mil páginas com expansão de memória (MARTÍNEZ DE SOUSA, 2010). Em 1998 também foi lançado o Softbook Reader, da Softbook Press. Cada dispositivo podia armazenar cerca de cinco mil páginas com textos, gráficos, ilustrações e figuras (PROCÓPIO, 2004).

Outros leitores dessa época citados por Martínez de Sousa (2010) e Procópio (2004) são: 
- AlphaBook,

- AONEPRO Reader,

- DEC Lectrice Virtual Book (conhecido por XLibris),

- $\quad$ EveryBook Dedicated Reader,

- GlassBook Reader,

- $\quad$ Go Reader,

- $\quad$ HanLin V3

- $\quad$ iLiad - fabricado por iRex e vendido na Espanha desde 2006

- $\quad$ Kindle da Amazon - lançado em 2007

- Librius [Millennium e-book]

- $\quad$ Papyre 6.1 - comercializado na Espanha e em Portugal por FactThor Innovación a partir de 2007

- Q-Reader,

- $\quad$ Sony Reader

- Victorian Laptop

De acordo com Reis e Rozados (2014) os aparelhos leitores de livros eletrônicos começaram a ser comercializados no Brasil em lojas físicas a partir de 2012, muitas vezes como resultado de parcerias de empresas estrangeiras com livrarias nacionais. Alguns nomes de aparelhos encontrados no país são:

- Positivo Alfa - Livraria Saraiva

- Kindle - Amazon (Vários modelos)

- Kobo - Livraria Cultura

- Lev - Saraiva

- COOL-ER

Além desses existem muitos outros modelos famosos no mercado internacional, como o Nook, da Livraria Barnes \& Noble e o Sony Reader, da Sony.

\subsubsection{Tablet}

O primeiro tablet a ser um sucesso de vendas foi o iPad da Apple. Depois eles viraram moda e vários outros modelos similares foram lançados por outras empresas. Os tablets possuem funções parecidas com as dos computadores e são compostos apenas de uma tela 
sensível ao toque. Eles são muito utilizados para navegar na Internet e também para jogos. Mas eles também permitem a leitura de livros, sendo que sua desvantagem em relação aos $e$-readers é que sua tela, por ser iluminada por trás, pode tornar a leitura desconfortável para os olhos. Entre as vantagens da leitura nos tablets está que eles, ao contrário dos e-readers, permitem a leitura de livros com imagens coloridas e de livros interativos, com várias funções inclusive vídeos ou livros que parecem jogos.

Por isso no momento da escolha entre a compra de um e-reader ou de um tablet devese levar em conta que eles possuem características próprias que precisam ser avaliadas. Se o objetivo é ler livros ou revistas com imagens coloridas, gráficos ou vídeos, e navegar na Internet a melhor opção é o tablet. Já se a pessoa deseja ler livros que possuem apenas o texto e deseja ter algumas funções como alterar o tamanho da letra, consultar um dicionário, ter uma tela que não cansa a vista e evitar a distração da Internet a melhor opção é um e-reader.

\subsubsection{Computador/Notebook}

O computador e o notebook, entre suas inúmeras funções, também permitem a leitura de livros eletrônicos. A experiência de leitura nesses dispositivos é similar à leitura nos tablets, devido à semelhança no funcionamento e às características das telas.

\subsubsection{Smartphone}

O uso de smartphones está amplamente disseminado no Brasil e no mundo. Eles funcionam como minicomputadores e fazem muito mais do que apenas telefonar como os seus antecessores. A leitura nesses dispositivos pode causar algum desconforto devido ao tamanho da tela, que pode ser muito pequena para a leitura, mesmo que as telas dos dispositivos comercializados atualmente variem muito de tamanho, indo de três a 6,4 polegadas.

Com a disseminação no uso dos smartphones surge uma importante possibilidade de aumento do público leitor de livros eletrônicos. Afinal, mais fácil que convencer as pessoas a adquirirem novos dispositivos é fazer com que algo que elas já possuem ganhe um novo uso. Essa é uma ótima oportunidade para as bibliotecas que não podem disponibilizar $e$-readers para os seus usuários. O uso dos smartphones para o empréstimo de livros eletrônicos deve ser utilizado pela biblioteca, trazendo também vantagens para os usuários, que podem carregar seus livros em um dispositivo que já está em seus bolsos. 


\subsection{PROGRAMAS PARA LER OS LIVROS ELETRÔNICOS}

A seguir serão apresentados os principais programas para leitura de livros eletrônicos em diversos tipos de dispositivos.

\subsubsection{Adobe Digital Editions}

O Adobe Digital Editions é um programa da empresa Adobe Systems, muito conhecida por ter desenvolvido o formato PDF. Ele permite a leitura de arquivos em PDF e em EPUB, incluindo o EPUB 3 (ADOBE, 2015). Esse programa pode ser utilizado para a leitura de livros comprados por pessoas físicas ou por bibliotecas que foram protegidos por DRM. Seu download pode ser feito gratuitamente pelo site da Adobe $^{3}$.

É esse programa que controla o acesso aos livros protegidos por DRM, autorizando a impressão, cópia ou empréstimo de acordo com as regras estabelecidas pelo autor ou editora (BARROS, 2014). Ele obtém essas informações a partir de um servidor de conteúdo ao qual ele está conectado, onde são armazenadas informações sobre o livro e os direitos designados a ele (BARROS, 2014).

Para utilizar o programa e acessar os livros protegidos por DRM é possível criar um cadastro com a empresa, que também é gratuito, chamado de Adobe ID (ADOBE, 2015). A Adobe permite que um mesmo ID seja utilizado em até seis diferentes dispositivos simultaneamente. Isso significa que um livro comprado ou emprestado pode ser lido, por exemplo, em um computador, um notebook, um tablet, um smartphone e um e-reader até que se alcance o máximo de seis dispositivos. Mesmo que o livro tenha sido comprado e todos os dispositivos sejam utilizados pela mesma pessoa, a tecnologia impõe o limite de seis usos simultâneos.

Se o programa é utilizado de maneira anônima, ou seja, sem estar associado a um cadastro, os livros protegidos por DRM ficam presos àquele dispositivo e não podem ser lidos em outro a não ser que seja feita uma nova compra ou empréstimo (ADOBE, 2015).

Esse programa está disponível para equipamentos com OS X (Apple) e Windows (BARROS, 2014).

\footnotetext{
${ }^{3}$ URL: http://www.adobe.com/br/solutions/ebook/digital-editions/download.html
} 


\subsection{2 iBooks}

O iBooks é o programa de leitura da Apple e já vem instalado no iPhone, iPad e iPod Touch. Ele não pode ser instalado no Windows.

Esse programa permite a leitura de livros comprados na loja da Apple (iTunes) e de arquivos em PDF sem DRM. Ele também permite a organização dessa coleção de livros, possui mecanismos de leitura como marcações e notas e compartilhamento de citações em redes sociais (APPLE, 2015).

O iBooks permite que a coleção de livros seja sincronizada nos dispositivos Apple do usuário. Assim, a pessoa pode começar a leitura em um dispositivo e se depois ela abre o mesmo livro em outro dispositivo, ele indica em qual página a leitura foi interrompida (BARROS, 2014).

Esse programa não é compatível com nenhum aparelho específico para a leitura de livros eletrônicos que utilize a tecnologia de papel eletrônico. $\mathrm{O}$ fato de ser compatível apenas com aparelhos de uma marca faz com que seu uso seja restrito.

\subsubsection{Kindle}

O Kindle é o programa que permite a leitura dos livros comprados na loja da Amazon. Com a instalação desse programa não é necessário possuir um e-reader Kindle para ler os livros da loja, permitindo que usuários de diversas plataformas possam comprar na Amazon.

Assim como o Adobe Digital Editions, esse programa permite que pelo uso de um cadastro de usuário seja possível sincronizar uma coleção pessoal em diversos dispositivos (BARROS, 2014).

Esse programa já vem instalado nos leitores Kindle e está disponível para Android, OS X (Apple), Windows e uso online sem instalação (BARROS, 2014).

\subsubsection{Google Play Livros}

O Google Play Livros é um aplicativo do Google para leitura de livros no sistema Android, presente em smartphones e tablets. Além da leitura é possível fazer ajustes no tamanho e tipo de letra, e acrescentar marcações e notas.

O Google Play Livros permite a leitura de livros comprados ou baixados gratuitamente da loja virtual Google Play. Nesse aplicativo também é possível ler arquivos em PDF e EPUB sem DRM. Mais versátil que o iBooks, ele também pode ser instalado em dispositivos da Apple. 


\subsubsection{Calibre}

O Calibre é um programa gratuito que permite a leitura e o gerenciamento da coleção de livros eletrônicos. Esse programa também pode ser utilizado para transferir os livros eletrônicos para outros dispositivos de leitura de qualquer marca. Também é possível alterar os metadados dos livros eletrônicos adicionados ao programa. O Calibre está disponível em português.

Ele permite a conversão de arquivos PDF sem DRM para outros formatos como EPUB ou AZW. Mas essa conversão muitas vezes apresenta problemas, dependendo da formatação original do PDF.

A vantagem do Calibre está na variedade de recursos que ele oferece quando comparado a outros programas. Sua desvantagem é que ele não é compatível com as lojas que vendem livros eletrônicos no Brasil e por isso pode ser utilizado apenas para gerenciar livros sem DRM.

Esse programa está disponível para OS X (Apple), Windows, Linux e autoinstalação em pen-drive (BARROS, 2014).

\subsection{AQUISIÇÃO ELETRÔNICA}

A aquisição de livros eletrônicos tem muitas características próprias, diferentes da compra de livros impressos. Além disso, a compra de livros eletrônicos para bibliotecas é diferente da compra para pessoas físicas.

\subsubsection{Comércio do livro eletrônico}

A comercialização de livros eletrônicos tem muitas diferenças quando comparada à comercialização de livros impressos. Primeiro porque ao comprar um livro impresso a pessoa possui o objeto, pode carregar consigo, ele é físico e palpável. Já na compra de um livro eletrônico é feito o download de um arquivo para um dispositivo, seja ele um computador, um celular, um aparelho leitor de livros eletrônicos ou qualquer outro dispositivo. Nesse caso não é possível tocar o livro. Existe a possibilidade de acessá-lo de qualquer lugar, bastando apenas abrir a página do vendedor, onde todas as suas aquisições estarão disponíveis para download.

Se o livro físico é molhado ou perdido não é possível recuperá-lo. Mas no caso do livro eletrônico, se o computador onde ele estava é danificado, perdido ou roubado, basta fazer um novo download para recuperar o livro igual ao que era antes. 
Devido às características do livro eletrônico, o mercado editorial exerce controle muito maior sobre eles (REIS; ROZADOS, 2014). O livro eletrônico não pertence ao comprador, que não possui controle sobre o produto adquirido. Quando o livro é eletrônico, ele pode apenas ser acessado nos aparelhos e programas autorizados pelo vendedor. Isso ocorre devido às proteções eletrônicas conhecidas como DRM (Digital Rights Management) que vêm embutidas no arquivo que contém o livro, permitindo o controle do seu uso.

É possível quebrar essa proteção, o que pode ser considerado um crime, mas as leis sobre crimes digitais não são claras. Mas, por regra, tudo o que pode ou não ser feito com um livro eletrônico é controlado pelo vendedor. Como exemplos podemos citar o número de dispositivos que podem ter acesso ao livro, a quantidade de páginas que podem ser impressas etc.

Esse controle pode chegar a extremos, e um caso real foi quando em julho de 2009 a Amazon apagou o livro "1984” de George Orwell dos aparelhos Kindle dos usuários, pois a editora que vendeu a edição eletrônica não possuía autorização do autor para vender o livro (PROCÓPIO, 2010 apud REIS; ROZADOS, 2014). Os compradores receberam seu dinheiro de volta, mas ficaram sem o livro. Isso prova o controle do vendedor sobre o conteúdo adquirido. Os livros já estavam nos aparelhos e foram removidos sem o consentimento dos compradores.

No Brasil, os livros eletrônicos são comercializados pelo mercado editorial desde 2009 (REIS; ROZADOS, 2014). Em 2012 a Apple e o Google Play abriram suas lojas virtuais no país.

Uma das vantagens inerentes ao livro eletrônico é que ele permite a auto publicação. Assim, os autores não são mais completamente dependentes das editoras para lançar seu trabalho. Pequenos autores que não seriam muito divulgados pelas editoras podem publicar seus livros por conta própria, associados a grandes empresas ou não, e podem ter uma porcentagem de lucro muito maior por cada exemplar vendido.

Algumas empresas oferecem auxílio a esses autores na publicação e comercialização de seus livros. A empresa Simplíssimo anuncia que os autores podem publicar com eles recebendo $70 \%$ de lucro. A Amazon também oferece um serviço de auto publicação.

Outra vantagem do comércio de livros eletrônicos é a rapidez para a publicação, já que ele necessita apenas do tempo necessário para edição, pois não há impressão e o envio é imediato. 


\subsubsection{Desenvolvimento de coleções eletrônicas}

O desenvolvimento de coleções é parte importante dos processos de uma biblioteca, pois decide e determina o que deve ou não fazer parte do seu acervo. Fazem parte do desenvolvimento de coleções a seleção, a aquisição por compra, permuta ou doação e o descarte e desbastamento de itens do acervo. A política de desenvolvimento de coleções é um documento norteador que ajuda na tomada de decisão nesse processo. É importante que esse processo seja organizado para que não haja desperdício dos recursos da biblioteca como a verba para compra. E, em caso de doação, os gastos com o processamento e armazenamento do material.

Uma questão que costuma preocupar os bibliotecários de aquisição é a decisão sobre a necessidade de duplicação do material, ou seja, se é necessário comprar a versão eletrônica e a impressa do mesmo material. Para ajudar nessa decisão, alguns pontos precisam ser avaliados. Se há período de embargo, a versão impressa é lançada antes da versão eletrônica. Quando não há embargo, o contrário pode ser verdade. É preciso analisar a urgência na utilização do material. O livro impresso só pode ser utilizado por um usuário de cada vez, enquanto o livro eletrônico, dependendo da modalidade de aquisição, pode ser lido por um número ilimitado de pessoas. Com a compra dos exemplares impressos pode ser mais fácil preservar as edições anteriores, já que elas não serão substituídas automaticamente pelas atuais como pode ocorrer com o exemplar eletrônico. Outra forma de driblar isso é se a própria biblioteca mantiver as cópias eletrônicas de todas as edições (DOUCETTE; LEWONTIN, 2012).

A aquisição "é o processo de localizar e adquirir materiais previamente identificados pelo processo de desenvolvimento de coleções” (GREGORY, 2011, p. 81, tradução nossa).

Um fator complicador para a aquisição de livros eletrônicos está no fato de que suas duas etapas, localização e compra, são difíceis. A localização é dificultada, pois os bibliotecários ainda não conhecem os vendedores. Além disso, as diferenças entre a compra a partir de agregadores, editoras e distribuidores ainda não é clara, principalmente por não ser comparável à compra de livros impressos.

O processo de compra dos livros eletrônicos envolve inúmeros fatores novos e decisões que não eram necessárias para a compra de livros impressos. Por exemplo, para comprar um livro eletrônico é necessário decidir se ele será utilizado por um usuário de cada vez ou por um número ilimitado de pessoas, e isso afeta o preço final do produto. A decisão do tempo que o usuário pode ficar com um livro que antes era parte da política de empréstimo da biblioteca agora deve ser feita no momento da aquisição, o que pode gerar confusão no processo. 
Sobre o departamento de aquisições, Wilkinson e Lewis (2003 apud GREGORY, 2011, p. 81, tradução nossa) dizem que ele:

é responsável por obter o material que os usuários necessitam, no formato mais apropriado e da maneira mais eficiente. Formatos e métodos podem mudar, mas a responsabilidade e as funções de aquisição de materiais de biblioteca continuam sendo o coração do departamento de aquisições.

Assim, o setor de aquisições busca adquirir o que a política de desenvolvimento de coleções decidir que é necessário para a biblioteca. E essa aquisição deve ser feita da maneira mais vantajosa para os usuários da biblioteca, o que inclui a compra de materiais em diversos formatos.

Sobre o que deve ser comprado, a necessidade e a urgência dos usuários foi definida em poucas palavras por Daniel Melcher (1971 apud GREGORY, 2011, p. 81, tradução nossa): "eles querem o que eles querem, agora".

Isso mostra o imediatismo da necessidade informacional, que já estava presente em 1971 (que é o mesmo ano em que surgiram os livros eletrônicos) e agora é muito maior, pois a velocidade e a facilidade com que as pessoas acessam a informação cresceram muito. E os usuários buscam ver em suas bibliotecas as mesmas tecnologias e facilidades de acesso que utilizam em seu dia-a-dia, através dos seus aparelhos eletrônicos.

Gregory (2011) afirma que os recursos de uma biblioteca podem ser divididos em três categorias:

1. Aqueles que a biblioteca possui.

2. Aqueles dos quais a biblioteca possui a licença.

3. Aqueles que são acessados eletronicamente pela biblioteca ou pelos usuários.

Os materiais que a biblioteca possui chegaram a ela por compra, troca ou foram obtidos de forma gratuita. Independente de como esses materiais chegaram, eles são de posse da biblioteca e estão sob seu controle, dentro dos limites impostos pela lei de direito autoral (GREGORY, 2011).

Os materiais licenciados ou alugados pela biblioteca estão fisicamente sob seu controle por um tempo limitado, e são obtidos por um acordo contratual com o dono do material (GREGORY, 2011).

Os materiais acessados pela biblioteca são aqueles que envolvem a compra do direito de leitura (e às vezes download ou impressão) por intermédio de um agregador (GREGORY, 2011). 
A já arraigada cultura de propriedade do material influencia o processo de compra de tal maneira que às vezes a biblioteca faz acordos com termos que não são vantajosos, especialmente pelo alto custo para compra dos itens (GREGORY, 2011).

Os bibliotecários de aquisição devem ter cuidado ao considerar o impacto das restrições de licença no uso futuro das coleções (SCHAFFNER, 2001 apud GREGORY, 2011). Um exemplo disso é que na compra de um pacote a biblioteca frequentemente deve pagar por itens menos interessantes para poder ter o que ela realmente deseja (GREGORY, 2011). Também existem restrições inesperadas que são conhecidas e aplicadas apenas depois da compra, sem conhecimento prévio do comprador, e que já foram tidas como legais pela justiça (GREGORY, 2011).

Na compra de livros eletrônicos seu preço inclui taxas e direitos autorais, e o material muitas vezes não pertence à biblioteca, o que gera uma perda de controle (GREGORY, 2011). Algumas bibliotecas usam a verba do desenvolvimento de coleções para licenciar esses materiais. Outras exigem que os usuários paguem algumas ou todas as taxas. Todas essas características criam um elemento de incerteza sobre qual parte do orçamento deve ser destinada para compras e para custos com o acesso eletrônico (GREGORY, 2011).

Acesso versus posse

Alguns autores discutem a diferença entre possuir apenas o direito ao acesso em contraposição à posse do material. Tammaro e Salarelli (2008) defendem o equilíbrio entre a coleção local, adequada às necessidades de informação mais frequentes dos usuários, e a coleção remota. Reed Scott (1989 apud TAMMARO; SALARELLI, 2008) previu que a criação da coleção deixaria de ser um processo estático de aquisição de recursos para um processo dinâmico, que se preocupa em prover o acesso à informação.

As primeiras bibliotecas digitais obedeciam à regra do "conteúdo acima de tudo", mas aos poucos o foco foi deslocado para os serviços, construindo uma infraestrutura para acesso integrado a recursos digitais distribuídos (TAMMARO; SALARELLI, 2008).

Para ilustrar melhor as diferenças entre o desenvolvimento de coleções impressas e eletrônicas o quadro 1 compara as duas modalidades: 
Quadro 1 - Diferenças na compra de livros impressos e eletrônicos

\begin{tabular}{|c|c|}
\hline IMPRESSO & ELETRÔNICOS \\
\hline $\begin{array}{l}\text { O livro chega à biblioteca por meio de } \\
\text { compra, doação ou permuta }\end{array}$ & $\begin{array}{l}\text { O livro chega à biblioteca por compra (pago, por } \\
\text { meio de vários modelos), o autor cede o direito } \\
\text { de acesso para a biblioteca (teses e dissertações), } \\
\text { a obra é de domínio público ou a obra é de } \\
\text { acesso livre (ex.: Creative Commons) }\end{array}$ \\
\hline O livro é comprado & $\begin{array}{l}\text { O livro pode ser comprado com acesso perpétuo, } \\
\text { assinado por um ano ou alugado apenas para um } \\
\text { empréstimo (completo ou por capítulos) }\end{array}$ \\
\hline $\begin{array}{l}\text { O livro comprado pertence fisicamente à } \\
\text { biblioteca }\end{array}$ & $\begin{array}{l}\text { O arquivo digital pode ficar na plataforma do } \\
\text { vendedor ou na biblioteca em um } \mathrm{HD}, \mathrm{CD}, \mathrm{DVD} \\
\text { ou em um servidor próprio }\end{array}$ \\
\hline $\begin{array}{l}\text { O conteúdo vem no suporte físico e é de } \\
\text { fácil acesso }\end{array}$ & $\begin{array}{l}\text { O conteúdo tem suporte digital, pode ter vários } \\
\text { formatos (epub, pdf) e necessita de um suporte } \\
\text { adicional para acesso (computador, tablet, } \\
\text { smartphone ou eReader) }\end{array}$ \\
\hline $\begin{array}{l}\text { O processo de compra e processamento } \\
\text { do material é lento, por isso ele demora a } \\
\text { chegar nas mãos do leitor }\end{array}$ & Logo após a compra o livro já está disponível \\
\hline $\begin{array}{l}\text { A biblioteca compra edições novas e } \\
\text { continua possuindo as antigas }\end{array}$ & $\begin{array}{l}\text { As edições mais recentes podem substituir as } \\
\text { antigas automaticamente, e a biblioteca perde } \\
\text { acesso às edições anteriores }\end{array}$ \\
\hline O livro possui um preço determinado & $\begin{array}{l}\text { O livro pode ser mais barato que a edição } \\
\text { impressa ou pode custar várias vezes mais }\end{array}$ \\
\hline $\begin{array}{l}\text { A biblioteca gera as suas próprias } \\
\text { estatísticas de uso através do software de } \\
\text { bibliotecas }\end{array}$ & $\begin{array}{l}\text { A biblioteca depende do fornecedor para acessar } \\
\text { as estatísticas de uso }\end{array}$ \\
\hline Política de descarte & Renovação/ Cancelamento \\
\hline
\end{tabular}

Fonte: Autoria própria.

\subsection{MODELOS DE COMERCIALIZAÇÃO DE LIVROS ELETRÔNICOS PARA BIBLIOTECAS}

Por esse ser um assunto recente e os aspectos terminológicos ainda não estarem consolidados, cada autor adota uma tipologia ou classificação diferente ao tratar dos modelos de negócios de venda de livros eletrônicos. Por isso, foi utilizada uma divisão própria, que é uma combinação das utilizadas por outros autores, para poder tratar do assunto com maior abrangência. Inicialmente são descritos os meios atuais através dos quais as bibliotecas podem comprar os livros eletrônicos, a saber: as editoras, os agregadores e os distribuidores. Depois, são analisados os principais modelos de seleção, dos quais os mais comuns são por título ou por pacote. Os modelos de negócios disponíveis atualmente para a biblioteca incluem o acesso perpétuo, a assinatura, o empréstimo de curto prazo e a aquisição orientada pelo usuário. 
Existem também algumas variações quando são tratados os modelos de acesso dos usuários, que podem ser restritivos, permitindo apenas o acesso de um usuário por vez, mais abrangentes, provendo o acesso a um número limitado de pessoas ou até ilimitado e simultâneo. Também existem variações sobre quem acessa e de onde os livros eletrônicos podem ser consultados. $\mathrm{Na}$ ocasião da compra é importante analisar com atenção a licença ou o contrato assinado no momento da venda, verificando as condições que são impostas à biblioteca, os deveres do vendedor e se ele permite ou não o empréstimo entre bibliotecas.

\subsubsection{Vendedores de livros eletrônicos}

O vendedor ou fornecedor é o canal através do qual a biblioteca pode comprar livros eletrônicos. Mas esse processo pode ser muito diferente da compra tradicional dos livros impressos, conforme já observado pela American Library Association (2012), pois nem todos os vendedores de livros eletrônicos aceitam vender para bibliotecas com medo da ampla divulgação e da pirataria que podem advir da disponibilização desse material em bibliotecas. As editoras Simon \& Schuster, Macmillan e Penguin, que junto com as editoras Hachette, HarperCollins e Random House fazem parte do grupo das seis editoras mais importantes dos Estados Unidos (Big Six), já se recusaram em algum momento a vender livros eletrônicos para bibliotecas (IFLA, 2014).

Com esse novo mercado surgem também novos termos, como agregador; ou novos significados para termos já existentes, como distribuidor. É importante destacar que apesar de agregador e distribuidor terem assumido significados diferentes, fornecedor e vendedor são comumente utilizados como sinônimos nos textos.

Apesar de ser um termo amplamente utilizado na literatura, não foi encontrada uma definição para o termo plataforma. Entretanto, a partir das leituras realizadas foi possível deduzir que uma plataforma de livros eletrônicos é o conjunto de soluções tecnológicas, que inclui a página da Internet, sua base de dados e tudo o que a acompanha, através da qual o vendedor oferece acesso ao material comprado.

As plataformas podem ser descritas e identificadas por algumas características: mercado de bibliotecas, tipo de plataforma, tipos de livros, assunto principal e modelos de negócios (RONCEVIC, 2013). Essas características foram utilizadas para identificar as plataformas apresentadas no artigo de Roncevic (2013).

Ao decidir pela compra de livros eletrônicos é importante ponderar como ela será feita, se diretamente de uma editora ou por meio de um agregador ou distribuidor. Essa decisão é 
importante já que posteriormente ela irá afetar como se dará o acesso dos usuários aos livros comprados, considerando que cada vendedor pode oferecer o acesso de uma maneira diferente.

Usar o mesmo fornecedor para a compra de livros impressos e eletrônicos pode trazer vantagens ao simplificar a administração dos pedidos, mas devido a limitações no conteúdo disponível para compra, talvez seja necessário trabalhar com vários fornecedores. Se um título em formato eletrônico ou se o conteúdo de uma determinada editora está disponível através de um único vendedor, esse pode ser um fator de decisão na escolha do fornecedor. Alguns livros eletrônicos podem estar disponíveis apenas por meio de agregadores, enquanto outros podem ser encontrados tanto com agregadores quanto na editora. É comum encontrar um livro eletrônico disponível para compra individual em um agregador e também integrando um pacote de uma editora. A situação se torna ainda mais complicada porque algumas empresas trabalham tanto como vendedoras de livros impressos quanto como agregadoras que fornecem livros eletrônicos, por exemplo. Mas devido às limitações de fornecimento dos agregadores, é possível que uma empresa venda o livro impresso, mas não tenha os direitos para vender a versão eletrônica do mesmo livro (GRIGSON, 2011, p. 7, tradução nossa).

No artigo de Grigson (2011) é possível encontrar muitas sugestões que podem ajudar no momento da escolha entre um vendedor e outro. A autora enumera os fatores que devem ser considerados na escolha de um novo vendedor para analisar o conteúdo que ele disponibiliza, para descobrir sobre a disponibilização de novos títulos e para analisar a qualidade do serviço oferecido. Ela também analisa os modelos de negócios de maneira didática, comparando a escolha entre títulos individuais ou pacotes, acesso perpétuo ou assinatura e número ilimitado de usos por ano ou número ilimitado de usuários simultâneos.

Roncevic (2013) destaca que nem sempre as diferenças entre editoras, agregadores e distribuidores são claras no mercado de livros eletrônicos. Alguns agregadores atuam também como editoras e distribuidores, enquanto algumas editoras optam por distribuir seus próprios livros eletrônicos e também os tornam amplamente disponíveis em outras plataformas. Devido a essa troca de papéis, os bibliotecários devem estar atentos para evitarem confusão e sobreposição de conteúdo.

\subsubsection{Editora}

Com o surgimento do mercado de livros eletrônicos algumas editoras que já trabalhavam com livros impressos decidiram participar também desse mercado. Assim como acontece com a compra por meio de agregadores e distribuidores, a compra feita diretamente com as editoras possui características próprias. Normalmente as editoras vendem livros agrupados em coleções e oferecem grandes descontos, se comparados com a versão impressa. 
A maioria dos livros eletrônicos disponíveis para compra é protegida por Digital Rights Management (DRM), que é um software que restringe o que o usuário pode fazer com o arquivo (como por exemplo, copiar ou imprimir) e que pode eliminar o acesso ao arquivo que contém o livro depois de um período determinado (DOUCETTE; LEWONTIN, 2012). O DRM das editoras pode ser mais aberto que o dos agregadores já que a própria editora monitora a atividade diretamente e pode identificar tentativas de pirataria com rapidez. As editoras se sentem mais seguras se as bibliotecas assinam um pacote de conteúdo completo. Algumas editoras, entretanto, não podem ou não querem vender títulos individuais para bibliotecas. Elas não oferecem planos de aprovação e a qualidade dos registros MARC varia muito de uma editora para outra (MORRIS; SIBERT, 2011).

Uma das vantagens para a biblioteca que compra diretamente da editora é a eliminação dos intermediários no processo de aquisição, o que economiza tempo e dinheiro. Além disso, as editoras são normalmente mais abertas a negociações do que os grandes agregadores e negociam com os bibliotecários para atender às suas necessidades específicas (RONCEVIC, 2013).

Algumas editoras grandes possuem suas próprias plataformas tecnológicas e vendem diretamente para bibliotecas, mas a desvantagem é que cada editora costuma oferecer apenas seus próprios títulos (GRIGSON, 2011). Isso é inconveniente quando comparado a agregadores e distribuidores que podem reunir o material de várias editoras, facilitando tanto a compra quanto o acesso aos livros por meio de uma única plataforma de informática.

As plataformas das editoras possuem uma aparência mais harmônica e são equipadas com melhorias como manutenção feita por editores e outros membros da equipe que conhecem o conteúdo. Suas plataformas, segundo Roncevic (2013), também podem apresentar conteúdos que não estão disponíveis nas versões dos livros oferecidas pelos agregadores, como funções multimídia.

Trabalhar simultaneamente com várias editoras é outra desvantagem, pois significa que há a coexistência de vários acordos, o que exige certo malabarismo e agilidade para lidar com negócios. Além disso, conforme bem observado por Roncevic (2013), aumenta o trabalho, já que bibliotecários e usuários precisam receber treinamento cada vez que uma nova plataforma de editora é contratada - infelizmente, ainda não existe um mínimo de padronização das interfaces desses sistemas.

Um bom lugar para começar a procurar por livros eletrônicos é com a mesma editora com a qual a biblioteca já está acostumada a comprar livros impressos. Muitas editoras possuem coleções de livros digitais organizadas por assunto. Os sites das editoras contêm as informações 
mais completas com listas de livros eletrônicos organizadas por assunto. Recomenda-se manter contato frequente com representantes de editoras, já que eles são muitas vezes a melhor fonte de informações sobre publicações a serem lançadas e a única fonte de preço institucional (DOUCETTE; LEWONTIN, 2012).

Seguem os nomes de algumas editoras que, no último trimestre de 2014, vendiam livros eletrônicos para bibliotecas brasileiras: Fórum, Cambridge (via EBSCO), IOP Publishing, Cengage, Wiley, Palgrave, Springer e Saraiva. Nessa categoria também se encontram a Minha Biblioteca e a Biblioteca Virtual Universitária, que são grupos de editoras que se uniram para facilitar o processo de venda (RESENDE, 2014). Os endereços dos sites dessas empresas se encontram no Apêndice A.

\subsubsection{Agregador}

Um agregador é uma organização que oferece livros eletrônicos por meio de uma plataforma tecnológica única. Ele pode oferecer títulos individuais ou coleções de livros eletrônicos de várias editoras (DOUCETTE; LEWONTIN, 2012). Os agregadores licenciam conteúdo das editoras e vendem diretamente para bibliotecas, hospedando os livros eletrônicos em uma plataforma computacional própria. Assim como os distribuidores, os agregadores costumam trabalhar com um grande número de editoras, incluindo as menores que não possuem plataformas próprias de livros eletrônicos. Entretanto, o conteúdo que pode ser disponibilizado pelos agregadores é limitado pelas licenças obtidas por eles. Segundo Grigson (2011), algumas editoras podem decidir não licenciar nenhum conteúdo por meio de agregadores, outras podem oferecer uma parte ou todo o seu conteúdo através de todos os principais agregadores, e algumas podem ter um contrato de exclusividade com um único agregador.

Os agregadores podem ajudar a simplificar o processo de compra, pois oferecem um ponto de acesso único em uma única licença, além de permitir a compra de livros de várias editoras em um único lugar. Tais características contribuem enormemente para reduzir o trabalho de uma biblioteca na busca e seleção de conteúdo para aquisição. Entretanto, algumas editoras não disponibilizam seus principais títulos por meio de agregadores ou não permitem a venda única de livros de séries. Algumas editoras, como apontam Morris e Sibert (2011), sequer utilizam agregadores na esperança de cortar o intermediário nesse fluxo comercial.

Os agregadores devem equilibrar as necessidades das bibliotecas para quem vendem com as preocupações das editoras que eles representam. Eles gostariam de oferecer às bibliotecas um acesso com o mínimo de restrições possível, mas uma política mais aberta 
poderia afastar as editoras. Além disso, se o modelo de negócios de um agregador não oferece um lucro significativo para as editoras, ele pode ter dificuldade em atrair novos conteúdos (MORRIS; SIBERT, 2011).

As vantagens dos livros eletrônicos disponíveis nas plataformas dos agregadores é que geralmente eles são pesquisáveis e também permitem buscas avançadas. Eles podem ser adquiridos de diversas maneiras já que cada agregador possui seu próprio modelo de negócios. Os bibliotecários devem conhecer as particularidades de cada agregador antes de realizar a compra (RONCEVIC, 2013).

Como os agregadores foram os primeiros a entrar no mercado dos livros eletrônicos, eles costumam ser pioneiros em funcionalidades técnicas e opções de compra. A vantagem de comprar de um agregador é que é necessário lidar apenas com uma licença de compra e a entrega é mais simples já que eles estão completamente integrados ao sistema de distribuição. Outra vantagem é que agregadores oferecem muitos títulos em um único lugar (RONCEVIC, 2013).

A desvantagem do agregador é que nem todos os títulos das editoras estão disponíveis, e muitos sofrem períodos de embargo previamente determinados pelas editoras antes do lançamento de sua versão eletrônica. Apesar de oferecerem acesso a uma grande quantidade de títulos, as plataformas de agregadores normalmente são caras, impõem limites mínimos de compra e não permitem a negociação já que os preços, assim como os períodos de embargo, são determinados pelas editoras (RONCEVIC, 2013).

EBSCO, Ebrary (Proquest), ACLS Humanities Ebook, Biblioteca Xeriph, Árvore de Livros e Nuvem de Livros são exemplos de agregadores que, no último trimestre de 2014, vendiam para bibliotecas brasileiras (RESENDE, 2014).

\subsubsection{Distribuidor}

Os distribuidores, que também podem ser conhecidos como representantes, vendem livros eletrônicos em nome das editoras e oferecem tanto ofertas de editoras individualmente quanto de coleções agregadas (DOUCETTE; LEWONTIN, 2012). O papel do distribuidor é fornecer apoio no momento da venda e quando a compra é concluída o acesso é fornecido através da página da editora. Assim como os distribuidores de livros impressos, eles oferecem obras de várias editoras. Mas enquanto um distribuidor de livros impressos oferece livros das principais editoras, o número de editoras oferecidas por um distribuidor de livros eletrônicos é 
mais limitado, porque algumas editoras vendem apenas diretamente, especialmente se os livros forem vendidos apenas por pacotes e não por títulos individuais (GRIGSON, 2011).

Apesar de distribuírem somente para editoras e agregadores, os distribuidores oferecem a vantagem de facilidade na aquisição, já que a compra do livro eletrônico pode ocorrer simultaneamente com a compra do livro impresso. Os livros eletrônicos podem ser comprados por meio de seus planos de aprovação, e eles possuem sistemas para notificar as bibliotecas sobre novos títulos eletrônicos que atendam as suas especificações. Eles também oferecem uma linha única para cobrança e para o recebimento dos registros MARC, que normalmente tem qualidade maior do que os oferecidos pelas editoras (MORRIS; SIBERT, 2011).

Alguns distribuidores que, no último trimestre de 2014, vendiam livros eletrônicos para bibliotecas brasileiras eram: ITMS Group, De Gruyter, DotLib, ACCUMON e Mienciclo Ebooks (RESENDE, 2014).

\subsubsection{Modelos de seleção}

A seleção de livros eletrônicos para compra pode ser feita por título de forma unitária, por pacotes ou por meio de planos de aprovação, onde os títulos são primeiramente enviados e depois selecionados. Nenhuma dessas formas de seleção é melhor que a outra, já que tudo depende das necessidades específicas de cada biblioteca. A seleção feita por título normalmente não provê descontos como os oferecidos para pacotes, mas o valor do pacote pode ser muito alto para uma biblioteca que necessita de apenas um livro contido nele.

Os pacotes podem ser organizados por assunto ou por data de publicação, e podem reunir livros de editoras diferentes. A escolha dos títulos inclusos no pacote pode ser feita completamente pelo vendedor ou ele pode oferecer à biblioteca alguma influência na seleção dos títulos. Na compra de um pacote o custo de cada título costuma ser menor e se os títulos são selecionados pelo vendedor, isso poupa tempo dos bibliotecários de seleção. Por isso a compra de pacotes pode ser uma maneira rápida e barata de desenvolver a coleção. Uma desvantagem da compra por pacote, segundo Grigson (2011), é que a biblioteca paga por conteúdo que pode não ser utilizado, o que representa um desperdício de recursos valiosos. Para estimar o valor dessas coleções é pertinente que a biblioteca veja o custo por uso e não o custo por título (GRIGSON, 2009 apud MORRIS; SIBERT, 2011).

Outras vantagens na compra de uma coleção estão na variedade de livros sobre diversos assuntos e na economia. A desvantagem é que os usuários podem acabar ficando com uma edição desatualizada de um livro, perdendo informação atual que pode estar disponível através 
de outro fornecedor ou da cópia impressa. É importante que o bibliotecário esteja atento no momento da seleção, pois algumas coleções de agregadores podem conter edições mais antigas dos livros. Basta dar uma olhada rápida nas datas de publicação de algumas coleções para constatar a falta de livros do ano atual. Deve-se perguntar ao fornecedor se as limitações na atualização dos livros da coleção se devem à disponibilidade da editora ou a acordos contratuais (DOUCETTE; LEWONTIN, 2012).

Se existe uma preocupação com a atualidade do material, uma conversa com o fornecedor pode oferecer uma estimativa do espaço de tempo entre a publicação impressa e do seu equivalente digital. Como sempre, o custo de manutenção de uma coleção atualizada influencia na quantidade de livros que podem ser comprados (DOUCETTE; LEWONTIN, 2012).

Se, entretanto, houver necessidade de possuir as edições anteriores de um título além da edição atualizada, é conveniente adquirir o acesso perpétuo a tais edições. Algumas editoras simplesmente atualizam a informação anualmente e não possuem um modelo que provê o acesso a edições antigas. Nesse caso, talvez seja necessário comprar cópias impressas para garantir o acesso. $\mathrm{O}$ apoio de terceiros está disponível para acessar edições antigas de livros eletrônicos mesmo quando as editoras já não existem mais. Para uma biblioteca universitária que mantém várias edições do mesmo título, investigar as ofertas de editoras e os direitos de acesso em longo prazo pode ser essencial (DOUCETTE; LEWONTIN, 2012).

O quadro 2 resume os pontos principais a serem levados em conta na escolha do modelo de seleção.

Quadro 2 - Comparação dos modelos de seleção.

\begin{tabular}{|l|l|l|}
\hline Título & Pacote & Comentários \\
\hline Mais caro. & O preço por título é menor. & \\
\hline $\begin{array}{l}\text { Controle da edição comprada, } \\
\text { que pode ficar desatualizada. }\end{array}$ & $\begin{array}{l}\text { As edições podem ser } \\
\text { atualizadas automaticamente, } \\
\text { sem controle sobre edições } \\
\text { antigas. }\end{array}$ & $\begin{array}{l}\text { O pacote pode ser mais barato } \\
\text { por conter apenas edições } \\
\text { antigas. }\end{array}$ \\
\hline $\begin{array}{l}\text { O comprador escolhe e paga } \\
\text { apenas o que quer. }\end{array}$ & $\begin{array}{l}\text { Os títulos são escolhidos pelo } \\
\text { vendedor (principalmente se for } \\
\text { uma base completa). }\end{array}$ & $\begin{array}{l}\text { Alguns vendedores permitem } \\
\text { que a biblioteca escolha quais } \\
\text { livros irão compor o pacote. }\end{array}$ \\
\hline Exige seleção. & $\begin{array}{l}\text { Os livros são previamente } \\
\text { selecionados por assunto. }\end{array}$ & $\begin{array}{l}\text { A seleção prévia pode trazer } \\
\text { títulos que não interessam. }\end{array}$ \\
\hline Só vem o que é selecionado. & $\begin{array}{l}\text { Variedade de títulos e assuntos. } \\
\text { Os usuários podem se interessar } \\
\text { por títulos desconhecidos pelos } \\
\text { bibliotecários. }\end{array}$ \\
\hline $\begin{array}{l}\text { Só paga o que vai utilizar (custo } \\
\text { por título). }\end{array}$ & $\begin{array}{l}\text { Paga por itens desnecessários, é } \\
\text { preciso avaliar se o custo } \\
\text { compensa (custo por uso). }\end{array}$ & \\
\hline
\end{tabular}

Fonte: Autoria própria. 
Outra opção para a seleção de livros eletrônicos é o uso de planos de aprovação. Nesse modelo os livros são primeiramente "enviados" para a biblioteca, que então decide se quer comprá-los ou não (MORRIS; SIBERT, 2011). Alguns distribuidores de livros eletrônicos oferecem a possibilidade de criar um plano de aprovação utilizando os mesmos critérios usados para os livros em papel: assunto, público, editora e preço. Todos os livros selecionados para aprovação serão adicionados ao site do distribuidor onde os responsáveis pela seleção podem avaliar e aprovar, rejeitar ou adicionar o livro à lista de desejos. Alguns distribuidores possuem aprovação de compra automática, a não ser que o livro seja rejeitado (DOUCETTE; LEWONTIN, 2012).

É importante que essas aprovações sejam revisadas a tempo de impedir que títulos não desejados sejam comprados. É preferível que o vendedor ofereça o texto completo para ser aprovado em um período determinado para que quem selecione possa ver o que está sendo comprado em lugar de apenas uma descrição ou algumas páginas do livro. A pré-visualização do texto completo desses livros oferece mais informações do que o que era disponibilizado anteriormente para os bibliotecários. Alguns planos de aprovação permitem que as bibliotecas recebam notificações sobre novos livros eletrônicos que são lançados que preenchem os critérios identificados (DOUCETTE; LEWONTIN, 2012).

Outros modelos de seleção citados por Morris e Sibert (2011) são o "firm order", que é um pedido que se não for cancelado no prazo de 30 dias se torna válido, e o "standing order", que é uma encomenda permanente.

\subsubsection{Modelos de negócio}

Os modelos de negócio existentes para a compra de livros eletrônicos para bibliotecas são bem variados e incluem o acesso perpétuo, a assinatura, o empréstimo de curto prazo e a aquisição orientada pelo usuário.

O tipo de compra escolhido pela biblioteca, seja ele o acesso perpétuo ou a assinatura anual, deve ser adequado às necessidades informacionais dos usuários. Se a necessidade é de possuir a edição mais recente, a assinatura é o modelo adequado, principalmente se novas edições são publicadas com frequência e atualizadas ao longo do ano. O custo da assinatura é um gasto anual. Mas quando um livro tem um valor mais duradouro ou é publicado com pouca frequência, o acesso perpétuo é o modelo ideal. As grandes bibliotecas podem decidir ter uma coleção mais completa de livros eletrônicos e por isso se beneficiam do acesso perpétuo. Em 
bibliotecas onde os usuários desejam principalmente livros novos ou edições recentes, a combinação de acesso perpétuo e assinatura anual pode ser mais vantajosa (DOUCETTE; LEWONTIN, 2012).

É necessário decidir se o orçamento deve ser usado em uma coleção frequentemente atualizada ou para aumentar o número de títulos de livros eletrônicos disponíveis aos usuários. Dependendo da estrutura do orçamento, é possível fazer uma compra de fim de ano. Os vendedores de livros eletrônicos frequentemente vão às bibliotecas nessa época do ano oferecendo grandes descontos. Aproveitar essas ofertas pode ser a alternativa para expandir a coleção a um custo reduzido. No fim das contas, ambos os modelos devem ser estudados para garantir a seleção dos títulos desejados com uma otimização dos gastos (DOUCETTE; LEWONTIN, 2012).

\subsubsection{Acesso perpétuo}

Nesse modelo a biblioteca paga para ter acesso perpétuo ao título escolhido. O modelo de acesso perpétuo está mais alinhado com o desenvolvimento de coleções em papel, onde a biblioteca não se preocupa apenas com o acesso atual, mas também com o futuro. Segundo Morris e Sibert (2011), o preço de cada exemplar do livro eletrônico para acesso perpétuo é normalmente maior que o do livro impresso. Além disso, nem todos os exemplares que podem ser assinados estarão disponíveis para aquisição perpétua, já que essa é uma decisão da editora. Para evitar gastos desnecessários a biblioteca deve analisar com cuidado se o modelo mais adequado de aquisição é o acesso perpétuo ou a assinatura.

Depois de adquirir o acesso perpétuo a livros eletrônicos a biblioteca deve se preocupar em oferecer o acesso a esses livros. Esse acesso normalmente ocorre por meio de uma plataforma online que pode ser própria da biblioteca ou contratada do mesmo vendedor dos livros por uma taxa. Assim, mesmo que a biblioteca já tenha pagado pelo direito ao acesso, também é necessário que exista uma plataforma online que é onde os usuários vão efetivamente acessar o material adquirido. Para usar a plataforma online do vendedor, que pode oferecer um software personalizado e atualizado, é necessário pagar uma taxa anual (DOUCETTE; LEWONTIN, 2012).

Entretanto, a biblioteca pode decidir não pagar pela plataforma do vendedor e se tornar ela mesma responsável pela disponibilização do material. Essa escolha deve ser feita com cuidado, pois a hospedagem e disponibilização dos livros eletrônicos envolvem muitos fatores, que incluem a preservação do arquivo que contém o livro e a manutenção de servidores. Esse 
processo pode ser muito caro para algumas bibliotecas e exige o emprego de profissionais de informática além de outros custos adicionais.

Um exemplo de biblioteca, citado por Roncevic (2013), que optou pela aquisição perpétua, mas decidiu hospedar seus próprios livros e não pagar pela plataforma do vendedor é a Douglas County Libraries, nos Estados Unidos. Eles compraram os livros diretamente das editoras e hospedam esse conteúdo no Adobe Content Server, que é um programa específico para lidar com esse tipo de material. Assim, eles compram livros com desconto de centenas de editoras. Nesse caso a biblioteca possui os livros, assim como seria com os livros impressos. Esse modelo onde a biblioteca compra, possui e distribui ela mesma os livros já foi copiado por diversas bibliotecas públicas nos Estados Unidos e, de acordo com Roncevic (2013), promete ganhar mais seguidores no futuro.

Mesmo que a biblioteca decida hospedar seus livros na plataforma do fornecedor é necessário tomar alguns cuidados para criar uma estrutura para assegurar o acesso contínuo no caso de falência do fornecedor já que o arquivamento é atualmente um problema para bibliotecas e vendedores que desejam oferecer acesso perpétuo aos livros eletrônicos. Por isso muitas bibliotecas relutam em colecionar livros eletrônicos antes que seja encontrada uma solução segura e definitiva (MORRIS; SIBERT, 2011).

O Quadro 3 a seguir compara as características da escolha entre a plataforma do vendedor e uma plataforma própria.

Quadro 3 - Plataformas

\begin{tabular}{|l|l|}
\hline Plataforma do vendedor & Plataforma própria \\
\hline $\begin{array}{l}\text { Quem se preocupa com a preservação digital } \\
\text { é o vendedor. }\end{array}$ & $\begin{array}{l}\text { Preocupação com a preservação digital dos } \\
\text { arquivos. }\end{array}$ \\
\hline A manutenção é feita pelo vendedor. & $\begin{array}{l}\text { Exigência de profissionais de informática } \\
\text { para manutenção da plataforma. }\end{array}$ \\
\hline $\begin{array}{l}\text { O custo com a manutenção é determinado } \\
\text { pelo vendedor e deve sofrer aumentos anuais. }\end{array}$ & $\begin{array}{l}\text { Os custos com a manutenção da plataforma } \\
\text { podem variar. Eles são maiores no início, } \\
\text { quando é necessário investir em } \\
\text { equipamentos e quando estes precisarem ser } \\
\text { trocados. }\end{array}$ \\
\hline $\begin{array}{l}\text { O vendedor define como será a interface e as } \\
\text { funcionalidades. }\end{array}$ & $\begin{array}{l}\text { A própria biblioteca define como será a } \\
\text { interface e as funcionalidades de empréstimo. }\end{array}$ \\
\hline $\begin{array}{l}\text { O vendedor define a tecnologia utilizada na } \\
\text { construção da plataforma. }\end{array}$ & $\begin{array}{l}\text { A biblioteca escolhe qual será a tecnologia } \\
\text { utilizada na construção da plataforma. }\end{array}$ \\
\hline $\begin{array}{l}\text { A biblioteca pode possuir login e senha para } \\
\text { acessar as estatísticas ou pode depender que } \\
\text { elas sejam enviadas pelo fornecedor. }\end{array}$ & $\begin{array}{l}\text { A biblioteca possui controle total sobre as } \\
\text { estatísticas de uso do material. }\end{array}$ \\
\hline
\end{tabular}

Fonte: Autoria própria. 
Quando a biblioteca adquire um livro por meio do acesso perpétuo o arquivo digital que contém o livro não vai necessariamente ser enviado para a biblioteca. Isso depende do acordo de venda. Por isso, depois de tanta energia gasta na seleção e na negociação, é importante entender quais são os direitos da biblioteca caso os livros eletrônicos se tornem indisponíveis. O que significa acesso perpétuo a um livro eletrônico se a biblioteca deixa de comprar de um fornecedor ou se ele sai do mercado? Os livros serão hospedados num site de arquivamento eletrônico de terceiros, como Portico, ou serão recebidos em CD-ROM por correio? Autores como Doucette e Lewontin (2012) sugerem que sejam esclarecidos quais são os planos de contingência do fornecedor, e incluídos detalhes dos planos na licença para que seja possível manter os livros eletrônicos em uma plataforma acessível e não em uma pilha inacessível de CD.

Se o vendedor é um agregador e trabalha com várias editoras diferentes, investigue seus direitos sobre os títulos da coleção que está sendo comprada. O acesso é garantido caso a editora deixe de oferecer seus títulos na plataforma do agregador? Apesar do pagamento de taxas anuais para livros comprados ser necessário, deve-se tentar limitar a perda de títulos selecionados investigando sobre os direitos de quem compra e de quem distribui em relação a editoras oferecidas antes da compra (DOUCETTE; LEWONTIN, 2012).

Garantir o acesso a recursos que foram pagos com dinheiro da biblioteca é uma preocupação fundamental. No mundo do papel, isso envolve a preservação física do material para uso futuro. Por outro lado, no mundo digital, a preservação é um pouco mais complicada. A infraestrutura existente para garantir o acesso a periódicos eletrônicos - através de Portico e LOCKSS, por exemplo - está sendo adaptada para acomodar livros eletrônicos para preservação. Bibliotecas, fornecedores e editoras vão precisar trabalhar juntos para desenvolver métodos através dos quais as bibliotecas possam preservar o conteúdo dos livros eletrônicos dos quais ela tenha direito de acesso perpétuo (MORRIS; SIBERT, 2011).

\subsubsection{Assinatura}

No modelo de assinatura a biblioteca adquire apenas o direito de acesso aos livros por um período determinado, que geralmente é de um ano. Quando termina o contrato, é necessário que ele seja renovado ou os usuários já não terão mais acesso aos livros. Esse modelo é mais adequado quando a biblioteca não tem interesse em ter os livros em seu acervo para sempre. Como em toda assinatura, o custo de renovação anual pode ser problemático para as bibliotecas (MORRIS; SIBERT, 2011). 
Um modelo diferenciado de assinatura foi criado pela editora americana Simon \& Schuster em parceria com as bibliotecas públicas dos Estados Unidos. Nesse modelo, a editora disponibiliza todo o seu catálogo, sem restrições e sem períodos de embargo, para as bibliotecas. A assinatura tem a duração de um ano e não há um limite no número de empréstimos de cada título. $\mathrm{O}$ acesso simultâneo, entretanto, é limitado a apenas um usuário por vez. O diferencial desse modelo é que os usuários que não desejarem esperar para ler o livro podem realizar a compra através desse mesmo sistema e parte dos lucros é revertida para a biblioteca (INOUYE, 2014).

\section{- Troca de títulos}

Depois de selecionar uma coleção de livros eletrônicos, a biblioteca pode descobrir, a partir das estatísticas de uso, que os usuários estão muito satisfeitos com alguns livros e desinteressados em outros. A possibilidade de trocar livros eletrônicos de uma coleção é uma segunda chance para fazer uma seleção ou um acervo mais útil. Atualmente, algumas editoras oferecem coleções onde os livros estão disponíveis por certo período, e depois podem ser trocados por títulos diferentes. A ProQuest está trabalhando atualmente com a Safari, uma vendedora de livros eletrônicos de computação e negócios. No modelo da Safari, a biblioteca compra certo número de vagas. No site da Safari é possível acessar informações de uso e fazer a troca dos livros. Depois de um período de seis meses, é possível começar a avaliar o uso dos livros eletrônicos. Alguns títulos serão muito utilizados e outros não. Ao invés de deixar livros pouco ou nunca usados na plataforma, deve-se considerar a remoção desses títulos e a escolha de outros. O modelo de troca requer trabalho por parte do catalogador, que deve manter o catálogo atualizado para garantir que nenhum usuário tente acessar um livro que já não está mais disponível (DOUCETTE; LEWONTIN, 2012).

- Limite de número de acessos por título

Nesse modelo a biblioteca adquire o direito a um número determinado de acessos a um exemplar. Depois que o livro for acessado por esse número determinado de vezes ele se torna indisponível para os usuários e a biblioteca deve então pagar mais uma vez para que esse acesso possa ser renovado. Esse modelo é indicado para livros que serão pouco acessados durante o período em que durar o contrato, ou que serão muito utilizados durante um curto período por usuários diferentes. A desvantagem desse modelo é que o bibliotecário deve estar atento para renovar a assinatura dos títulos que já atingiram o limite de acessos, para evitar que os usuários tenham seu acesso negado. 
O quadro 4 a seguir compara os dois principais modelos de negócios disponíveis no Brasil.

Quadro 4 - Modelos de negócios

\begin{tabular}{|c|c|c|}
\hline Acesso perpétuo & Assinatura & Comentários \\
\hline $\begin{array}{lll}\text { Acesso } & \text { por } & \text { período } \\
\text { ilimitado. } & & \end{array}$ & $\begin{array}{l}\text { Acesso por um período } \\
\text { determinado, geralmente por } \\
\text { um ano. }\end{array}$ & $\begin{array}{l}\text { Há quem entenda que se a } \\
\text { biblioteca pagou pela } \\
\text { assinatura em um ano e não } \\
\text { renovou o contrato, pode } \\
\text { continuar acessando o } \\
\text { conteúdo que estava } \\
\text { disponível no ano em que } \\
\text { pagou. }\end{array}$ \\
\hline $\begin{array}{l}\text { A edição comprada pode não } \\
\text { ser } \quad \text { atualizada } \\
\text { automaticamente. }\end{array}$ & $\begin{array}{l}\text { A edição mais recente } \\
\text { sempre está disponível, e } \\
\text { pode ser atualizada ao longo } \\
\text { do ano. }\end{array}$ & \\
\hline O livro é pago de uma vez. & $\begin{array}{l}\text { A assinatura precisa ser } \\
\text { renovada todos os anos. }\end{array}$ & $\begin{array}{l}\text { Mesmo com a compra } \\
\text { perpétua pode ser necessário } \\
\text { pagar uma taxa de acesso à } \\
\text { base. }\end{array}$ \\
\hline $\begin{array}{l}\text { Bom para livros com valor } \\
\text { duradouro, cujo conteúdo } \\
\text { não envelhece. }\end{array}$ & $\begin{array}{l}\text { Bom para livros que } \\
\text { precisam estar sempre } \\
\text { atualizados. }\end{array}$ & \\
\hline Garante o acesso futuro. & O aceso é apenas temporário. & \\
\hline $\begin{array}{l}\text { Preço mais elevado por } \\
\text { título. }\end{array}$ & O custo por título é menor. & \\
\hline $\begin{array}{l}\text { Nem todos os exemplares } \\
\text { disponíveis para assinatura } \\
\text { podem ser adquiridos por } \\
\text { acesso perpétuo. }\end{array}$ & $\begin{array}{l}\text { Todos os exemplares } \\
\text { costumam estar disponíveis } \\
\text { nessa modalidade. }\end{array}$ & \\
\hline $\begin{array}{l}\text { A biblioteca pode ou não ter } \\
\text { acesso ao arquivo que } \\
\text { contém o livro. }\end{array}$ & $\begin{array}{l}\text { A biblioteca pode ou não ter } \\
\text { acesso ao arquivo que } \\
\text { contém o livro. }\end{array}$ & $\begin{array}{l}\text { A posse do arquivo digital } \\
\text { depende do acordo feito com } \\
\text { o vendedor. }\end{array}$ \\
\hline Não permite a troca de livros. & $\begin{array}{l}\text { Pode permitir a troca de } \\
\text { livros pouco utilizados. }\end{array}$ & \\
\hline
\end{tabular}

Fonte: Autoria própria.

\subsubsection{Empréstimo de curto prazo}

Também conhecido como pay-per-view ou short term loan, é um aluguel de curto prazo onde a biblioteca paga apenas pelos títulos que são visualizados. A cobrança pode ser feita de diversas maneiras: por capítulo, por livro ou por seção visualizada. Talvez seja a maneira mais eficiente em termos de custo para oferecer acesso aos livros eletrônicos. A biblioteca deve pagar algumas taxas fixas, mas em relação aos livros, paga apenas por aqueles que são efetivamente 
utilizados. Em 2007, o preço por esse tipo de aluguel variava entre $10 \%$ e $15 \%$ do valor total do livro. A EBL oferece um método de aquisição que combina o pay-per-view com a aquisição orientada pelo usuário, onde a biblioteca paga uma taxa limitada por uso e, uma vez alcançado o limite de acessos predeterminado, a biblioteca compra o livro automaticamente (MORRIS; SIBERT, 2011).

Vale a pena estudar o modelo pay-per-view porque ele oferece uma grande coleção de livros eletrônicos aos usuários sem o custo da compra ou da assinatura da coleção completa. Assim como no modelo de aquisição orientada pelo usuário é importante limitar a parte do orçamento a ser destinada para esse tipo de compra (DOUCETTE; LEWONTIN, 2012).

\subsubsection{Aquisição orientada pelo usuário}

A aquisição orientada pelo usuário (em inglês, também conhecida como patron-driven acquisition (PDA), patron-driven selection ou demand-driven acquisition (DDA)), é um modelo de compra no qual os usuários selecionam os livros eletrônicos escolhendo a partir do catálogo online da biblioteca. Nesse caso, a biblioteca e o vendedor determinam a quantidade e o tipo de uso que acionam a compra (DOUCETTE; LEWONTIN, 2012). O vendedor fornece acesso a todos os títulos de livros eletrônicos (ou a um grupo de títulos selecionado, dependendo de como a biblioteca quer que a coleção seja). A biblioteca incorpora os registros MARC ao seu catálogo, criando assim um ponto de descoberta dos títulos. E o usuário encontra e acessa o livro eletrônico na plataforma do vendedor. Depois de um número predeterminado de visitas, a biblioteca é cobrada pelo título e passa a possuir acesso a ele (MORRIS; SIBERT, 2011).

A biblioteca deve trabalhar com o vendedor para determinar os limites de compra, que podem incluir a quantidade de recursos financeiros que vai dedicar ao programa durante certo período, qual o valor máximo que um livro pode custar para ser incluído e os assuntos e disciplinas inclusas (MORRIS; SIBERT, 2011).

Separar uma parte do orçamento para experimentar esse tipo de aquisição garante que alguns livros eletrônicos comprados estão sendo usados e garante também a coleta de estatísticas sobre os desejos dos usuários (DOUCETTE; LEWONTIN, 2012).

As vantagens desse tipo de compra incluem a garantia de acesso aos títulos comprados, fluxo de aquisição automatizado e acesso instantâneo. As desvantagens são que um número menor de títulos é disponibilizado para esse tipo de compra, a resistência em mudar práticas consagradas de desenvolvimento de coleções e a falta de controle na seleção dos títulos (MORRIS; SIBERT, 2011). 
Um exemplo do uso deste modelo está no que aconteceu na Universidade do Texas em Austin, no ano fiscal de 2007/8. A Universidade optou por pagar por três visualizações no sistema pay-per-view, e a quarta visualização acionava a compra do livro. De um total de 300 mil dólares que foram disponibilizados, 2/3 foram gastos com aluguel dos títulos e o restante com compras. É interessante notar que todos os títulos selecionados para esse estudo eram de editoras que constituíam menos de 3\% do plano de aprovação para compra de livros impressos e cujos títulos tinham circulação abaixo da média com os exemplares impressos (MACICAK;

SCHELL, 2009 apud MORRIS; SIBERT, 2011).

\subsubsection{Modelo de acesso}

O modelo de acesso ao livro eletrônico também é importante, pois:

Ao contrário do que acontece com a coleção impressa, os livros selecionados nunca estarão fora da estante. Os usuários vão presumir que o livro eletrônico estará disponível para eles a qualquer momento. Infelizmente, esse não é sempre o caso. Como parte do processo de seleção, é importante entender como o acesso é fornecido aos usuários e então selecionar um modelo que atenda às necessidades da comunidade (DOUCETTE; LEWONTIN, 2012, p. 62, tradução nossa).

Os primeiros produtos relacionados aos livros eletrônicos simulavam os fluxos e estruturas dos livros impressos, em parte porque convencer as editoras a disponibilizar seu conteúdo de qualquer outra maneira era inconcebível. Conforme as editoras perceberam a vantagem financeira de oferecer livros eletrônicos para bibliotecas, passaram a aceitar os pedidos das bibliotecas de prover acesso a múltiplos usuários. Entretanto, elas não querem que a biblioteca substitua a compra de vários exemplares pela compra de um livro digital. A maioria das editoras permite o uso simultâneo dentro dos limites do uso ocasional. Os padrões de uso que refletem a utilização por uma grande comunidade de usuários da biblioteca exigem maiores taxas de acesso (MORRIS; SIBERT, 2011).

No momento do acesso, os vendedores normalmente tratam os livros eletrônicos como se cada livro comprado fosse similar a um volume físico. Assim, para que mais usuários possam acessar o mesmo livro ao mesmo tempo, a biblioteca deve adquirir mais exemplares digitais.

Para avaliar se o modelo de acesso escolhido está de acordo com as necessidades dos usuários, é importante avaliar as estatísticas de uso dos livros eletrônicos e, especialmente, o número de usuários com acesso negado. Um usuário com acesso negado indica que ele tentou utilizar um livro eletrônico, mas o seu acesso foi negado porque excedia o número fixo descrito na licença de usuários que podem acessar o livro ou a coleção simultaneamente. Se for 
observado um grande número de acessos negados a um livro eletrônico deve-se considerar a compra de mais cópias ou o aumento de usuários simultâneos (DOUCETTE; LEWONTIN, 2012).

\subsubsection{Um por vez}

Nesse modelo apenas um usuário pode ter acesso ao livro de cada vez. Se outros usuários tentam acessar o mesmo livro eles têm o seu acesso negado (MORRIS; SIBERT, 2011). Essa é a forma mais limitada de acesso. Essa forma não é recomendada para livros populares ou que serão requisitados por muitos usuários (DOUCETTE; LEWONTIN, 2012).

\subsubsection{Usuários múltiplos}

O modelo de usuários múltiplos permite que um número limitado de usuários (que geralmente é de três pessoas) acesse um mesmo livro simultaneamente. Normalmente custa um pouco mais que o modelo que permite o acesso único. Por exemplo, o sistema ebrary cobra $50 \%$ a mais pelo acesso multiusuário. É importante que a biblioteca considere as necessidades dos seus usuários ao decidir entre modelos de acesso simultâneo (MORRIS; SIBERT, 2011).

\subsubsection{Número ilimitado de usuários}

Permite que um número ilimitado de usuários acesse um mesmo livro simultaneamente. Apesar de ser mais caro, esse modelo é o ideal já que o usuário jamais será rejeitado por exceder o número permitido de acessos simultâneos.

\subsubsection{Meio de acesso e uso}

De acordo com Doucette e Lewontin (2012) os livros eletrônicos adquiridos pelas bibliotecas podem ser acessados de duas maneiras diferentes: online ou por meio de download. A diferença entre esses dois meios de acesso é tênue, já que ambos têm início na plataforma online do fornecedor. A diferença é que no acesso online o arquivo que contém o livro eletrônico é acessado diretamente e permanece durante todo o tempo na plataforma do fornecedor, que normalmente é paga periodicamente pela biblioteca (MORRIS; SIBERT, 2011). Quando é permitido o download o arquivo é transferido para o equipamento utilizado pelo usuário, que pode ser um computador, um smartphone ou um tablet, e apenas pode ser 
acessado por meio de um programa fornecido pelo vendedor que deve ser instalado no dispositivo. O programa da plataforma controla o que o usuário pode fazer com o livro, se é possível fazer o download, imprimir, enviar seções por e-mail ou adicionar notas e marcações (DOUCETTE; LEWONTIN, 2012).

O acesso à plataforma do fornecedor é controlado, já que esse é um serviço pago que não está aberto a qualquer um na Internet. Então, como controlar quem tem acesso à página? $\mathrm{O}$ fornecedor pode fazer isso limitando o acesso aos computadores da biblioteca, que devem ser previamente cadastrados ou permitindo o acesso remoto aos usuários através de login e senha.

Apesar de existir a possibilidade de acesso remoto que permite que os usuários tenham acesso aos livros quando e onde quiserem desde que haja uma conexão com a Internet, alguns vendedores apenas permitem que o download do livro seja feito na área da biblioteca, impondo uma limitação para algo que a tecnologia já permite (IFLA, 2014).

Alguns fornecedores de livros eletrônicos lidam com o acesso de maneira muito similar ao empréstimo de livros impressos, de maneira que o usuário faz um empréstimo do livro por um tempo determinado. Depois desse período, que é similar ao de empréstimo de livros impressos, o usuário não tem mais acesso ao livro (MORRIS; SIBERT, 2011).

O download de livros de uma biblioteca normalmente funciona de duas maneiras. Bibliotecas públicas e algumas universitárias oferecem livros eletrônicos que podem ser emprestados por um período fixo, e depois o acesso é removido pelo DRM. A maioria dos livros eletrônicos em bibliotecas universitárias funciona mais como um periódico, que oferece capítulos que podem ser baixados e guardados permanentemente pelo usuário (DOUCETTE; LEWONTIN, 2012).

\subsubsection{Licença de venda}

A compra de livros eletrônicos deve ser acompanhada por uma licença formal, que deve definir quem, onde e como os livros podem ser utilizados (GRIGSON, 2011). É importante que os termos dessa licença sejam analisados com atenção, já que ela é quem vai definir detalhes importantes sobre o uso do material comprado. Nessa licença, também devem constar as responsabilidades do vendedor, como por exemplo, a provisão de suporte técnico, treinamento para os funcionários da biblioteca, fornecimento de estatísticas de uso e garantias de acesso ao material comprado (GRIGSON, 2011).

Se os termos da licença não estiverem claros e forem ambíguos ou contraditórios eles devem ser esclarecidos pelo vendedor e se necessário deve-se buscar a ajuda de um advogado. 
Se os termos forem inaceitáveis devem ser renegociados e, se isso não for possível, deve-se buscar outra fonte para a compra do material (GRIGSON, 2011).

É importante que a biblioteca negocie todos os detalhes no momento da compra. Os principais pontos de discussão são a negociação dos preços, o uso simultâneo de usuários múltiplos, o uso apenas por usuários autorizados, a inflação, as taxas das plataformas de acesso, a forma como o acesso é oferecido, a qualidade dos registros MARC oferecidos, restrições de DRM e acesso dentro e fora do campus. $\mathrm{O}$ arquivamento, a garantia de acesso e a preservação digital do material adquirido também são pontos importantes que devem constar na licença de venda (VASILEIOU; ROWLEY; HARTLEY, 2012).

Um exemplo da volatilidade do mercado é o fato de que a editora Penguin deixou de oferecer livros por meio do OverDrive em 2012 (REID, 2012) e voltou a oferecê-los em 2013 (ALBANESE, 2013). As bibliotecas que já haviam adquirido os livros continuaram podendo emprestá-los (REID, 2012). Entretanto, para evitar desentendimentos é melhor que esse tipo de situação seja prevista na licença de venda.

Como a venda de livros eletrônicos para bibliotecas ainda não é expressiva, as editoras se sentem confiantes para impor preços e termos de licença (ALGENIO; THOMPSON YOUNG'S, 2005 apud VASILEIOU; ROWLEY; HARTLEY, 2012). O preço dos livros oferecidos às bibliotecas pode apresentar variações absurdas que vão do preço de varejo até três vezes mais e às vezes mais que isso. Assim, um mesmo livro pode custar 7,50 dólares na Amazon e 90 dólares para as bibliotecas no OverDrive (IFLA, 2014). Cabe aos bibliotecários desenvolverem estratégias para lidar com os vendedores e garantir que todos os contratos negociados reflitam os princípios de acesso e reforcem sua importância na academia (CANADIAN ASSOCIATION OF RESEARCH LIBRARIES, 2008 apud VASILEIOU; ROWLEY; HARTLEY, 2012).

Quando a compra é realizada por um órgão público o processo não é tão simples, pois não se pode simplesmente escolher algo e depois comprá-lo diretamente com o vendedor escolhido. Primeiro, a biblioteca deve elaborar o termo de referência ou o projeto básico, dependendo da modalidade de licitação, onde devem constar claramente as especificações do produto ou serviço a ser contratado (FERNANDES, 2015). Um termo de referência bem elaborado pode garantir o sucesso de uma compra, pois é nele que devem constar as exigências dos especialistas no assunto, daqueles que entendem sobre o produto que será adquirido (RUBEL, 2007). 
O edital da licitação, que é a fase seguinte, é elaborado por advogados que são auxiliados pelo termo de referência nessa etapa. Assim, o termo de referência "representa a forma com que os técnicos especialistas podem auxiliar os advogados" (RUBEL, 2007, p. 6). O edital é o documento que convoca os interessados na venda do produto ou serviço descrito por ele a se apresentarem, e deve incluir o termo de referência e outras especificações exigidas pela lei de licitações, Lei $\mathrm{n}^{\circ}$ 8.666/1993 (FERNANDES, 2015). Aquele que apresentar a oferta mais vantajosa para a administração pública dentro dos parâmetros estabelecidos pelo edital será o vencedor.

Depois que o vencedor é eleito o próximo passo é a elaboração do contrato, que é feito com base no termo de referência e no edital (FERNANDES, 2015). O contrato é um acordo entre as duas partes, o comprador e o vendedor, e estabelece regras para o relacionamento entre eles. $\mathrm{O}$ contrato é onde constam e são formalizados os termos da licença (FERNANDES, 2015). Os termos da licença determinam como será o uso do material, a parte de como será o suporte é parte do contrato (FERNANDES, 2015).

Muitas bibliotecas compraram os livros eletrônicos de vendedores que possuem cartas de exclusividade que comprovam que o produto vendido por eles é único. Nesse caso, diz-se que há inexigibilidade de licitação (GRANJEIRO; CARDOSO, 2013). A carta de exclusividade tem sido apresentada para um conjunto único de livros. Nesse caso, o problema é que se um autor deixa de fazer parte da base o produto já não é mais o mesmo, e talvez não haja mais a carta de exclusividade e consequentemente a inexigibilidade para a próxima compra (FERNANDES, 2015).

\subsubsection{Renovação e cancelamento}

Quando se trata da compra de livros eletrônicos não é comum se falar em descarte já que esse material não sofre com o desgaste físico como o livro impresso. Apesar disso, esse suporte possui características próprias que levam à necessidade de algo similar à uma "política de descarte". Isso porque os livros que não são adquiridos de forma perpétua devem ser renovados ou necessitam que sua assinatura seja cancelada.

Quando chega o momento de decidir entre a renovação e o cancelamento da assinatura muitos fatores devem ser levados em conta e os principais são uso e custo. A avaliação do custo envolve orçamento, preços de mercado e termos de licença (ANSON; CONNELL'S, 2009 apud VASILEIOU; ROWLEY; HARTLEY, 2012). A avaliação do uso é mais complicada, pois 
costuma envolver as estatísticas de uso oferecidas pelos vendedores, que podem ser de baixa qualidade, inconsistentes, inadequadas ou incompletas (VASILEIOU; ROWLEY; HARTLEY, 2012).

Além disso, atualidade e relevância do conteúdo, modelos de aquisição e licenciamento, acessibilidade e mudanças na plataforma de acesso também devem ser levados em conta nessa decisão (VASILEIOU; ROWLEY; HARTLEY, 2012).

\subsubsection{Modelos inovadores}

Em alguns lugares os bibliotecários já perceberam que quando estão unidos aumentam o seu poder de negociação com as editoras. As bibliotecas podem se beneficiar da negociação feita através de consórcios, já que eles podem trazer algumas vantagens como: melhores acordos do que se a biblioteca negociasse sozinha, redução de esforços ao negociar separadamente com cada editora, descontos nas taxas das plataformas de acesso e uma equipe experiente para negociar em nome dos membros do consórcio (VASILEIOU; ROWLEY; HARTLEY, 2012).

Na Europa o European Bureau of Library Information and Documentation Associations (EBLIDA) criou a campanha "The Right to E-read" que busca defender os direitos das bibliotecas de toda a Europa de comprar e oferecer livros eletrônicos para seus usuários assim como eles sempre fizeram com os livros impressos.

Na Dinamarca o próprio governo negociou diretamente com as editoras para criar a sua própria plataforma de livros eletrônicos para as bibliotecas públicas. Essa plataforma se chama eReolen e foi criada em 2011. O pagamento aos detentores dos direitos autorais é feito de acordo com o uso (IFLA, 2014).

A Holanda utiliza um sistema, chamado de Bibliotheek ${ }^{4}$, que foi criado em 2014 e é similar ao da Dinamarca. No sistema holandês o acesso aos livros de domínio público será gratuito e os usuários das bibliotecas públicas deverão pagar uma taxa extra para acessar os livros eletrônicos mais recentes. Além disso, no sistema holandês o acesso simultâneo é ilimitado (IFLA, 2014).

Na Alemanha foi criada a plataforma Onleihe $e^{5}$ que empresta livros eletrônicos, arquivos de áudio e vídeo, jornais e revistas eletrônicas (IFLA, 2014). Essa plataforma atende bibliotecas da Alemanha, Áustria, Suíça e Itália, além dos institutos Goethe espalhados pelo mundo. Cada

\footnotetext{
${ }^{4}$ URL: www.bibliotheek.nl

${ }^{5}$ URL: http://www.onleihe.net/
} 
usuário deve ser associado à uma biblioteca física e, portanto, se a biblioteca possui apenas um exemplar do livro digital, esse exemplar pode ser lido apenas por um usuário por vez. O tempo de empréstimo é estipulado por cada biblioteca e a devolução é controlada por DRM. Esse serviço não possui nenhum custo adicional além da taxa anual da biblioteca (ONLEIHE, 2014).

As bibliotecas públicas de Quebec, no Canadá, se uniram para formar a plataforma Pretnumerique.ca. Os livros adquiridos para esta plataforma possuem um limite total de 55 empréstimos sem um limite anual. A leitura dentro da biblioteca não conta para o limite de empréstimos. As bibliotecas definem a sua própria política de empréstimo, incluindo quantos livros um usuário pode pegar, o período de empréstimo etc. (IFLA, 2014).

$\mathrm{Na}$ Espanha, o governo criou o projeto eBiblio, que oferece o empréstimo de livros eletrônicos em todas as bibliotecas públicas do país. Foram disponibilizados 1.500 títulos que podem ser acessados pelos usuários das bibliotecas públicas. A plataforma escolhida para o gerenciamento dos livros se chama Libranda, e cada comunidade autônoma (região) gerencia sua plataforma, com exceção do País Basco, que possui uma plataforma própria (CORROTO, 2014).

Apesar de ter sido lançado recentemente, em 2014, já existem muitas críticas ao eBiblio. Existem reclamações sobre a imposição de uma plataforma única, a Libranda, às comunidades autônomas, que não puderam decidir qual plataforma preferiam ou se gostariam de utilizar mais de uma plataforma. O uso de uma única plataforma limita a quantidade de títulos disponíveis ao catálogo da Libranda. Além disso, o contrato com a Libranda é de um ano e não se sabe se ele será renovado pelo próprio Ministério da Educação, Cultura e Esportes ou se a renovação deverá ser paga pelas prefeituras (ayuntamientos) (CORROTO, 2014).

É destacado o fato de que foram compradas 200 mil licenças, que são os direitos autorais que permitem o uso dos livros e que é pago às editoras, e cada licença permite uma média de 28 usos ou leituras. Assim, o governo comprou, nessa fase inicial, 5,6 milhões de usos ou acessos aos livros (CORROTO, 2014).

A plataforma Libranda é compatível com iOS e Android, apenas os dispositivos Kindle não são compatíveis por problemas tecnológicos e legais. Uma vantagem dessa plataforma é que cada biblioteca pode complementar o acervo disponível como desejar, o que não é possível fazer nos Estados Unidos com o Overdrive (CORROTO, 2014). 


\subsection{DIREITOS AUTORAIS}

A legislação que rege os direitos autorais no Brasil é a lei no 9.610 de 19 de fevereiro de 1998. Essa lei prevê dois tipos de direito de autor: o moral e o patrimonial. O direito moral é o direito de criação da obra que não pode ser renunciado pelo autor. Já o direito patrimonial está ligado aos lucros obtidos com a obra. As obras em domínio público são aquelas que já não são mais protegidas pelo direito patrimonial, de acordo com as regras previstas na lei (BRASIL, 1998). Esses livros podem ser livremente reproduzidos e disponibilizados pela biblioteca aos seus usuários. Muitos dos livros em domínio público no Brasil podem ser encontrados na página do Portal Domínio Público ${ }^{6}$ do Governo brasileiro. Esses livros podem ter sua versão digital copiada e distribuída para leitura.

A lei de direito autoral brasileira, diferente de outros países como Espanha, não prevê limitação para bibliotecas. Diz-se limitação porque, quando ela existe, o autor não tem poder de decidir se seu livro vai ou não para as bibliotecas, já que essa é uma exceção prevista em lei.

A lei de direito autoral espanhola prevê o "derecho de explotación", que pode ser exclusivo (patrimonial) ou de remuneração, que é o direito de receber pelo trabalho que foi feito. Além disso, na Espanha, a lei prevê limitações para bibliotecas, museus, arquivos, fonotecas, hemerotecas e filmotecas. Essas instituições podem reproduzir obras para fins de investigação e conservação. A lei determina que podem ser realizados empréstimos, sem necessidade de autorização prévia, em instituições com fim educativo, cultural ou científico, e que para cada empréstimo realizado uma taxa deve ser paga ao autor (ESPANHA, 1996).

O copyright foi criado pela legislação de direitos autorais dos Estados Unidos e em contrapartida a ele surgiram os movimentos do copyleft e do Creative Commons. Essas são alternativas ao copyright que reconhecem o direito moral do autor, mas também permitem que ele decida se e como sua obra pode ser copiada e alterada por outra pessoa, e se isso pode ser feito apenas para fins não comerciais e se o uso comercial é permitido (WIKIPEDIA, 2014a e b).

Nos Estados Unidos a lei de direito autoral prevê o que eles chamam de "First sale doctrine" (direito de primeira venda) ou "princípio de exaustão". O detentor do direito autoral possui o direito exclusivo sobre a publicação ou a não publicação de uma obra, mas depois da primeira venda o seu direito de distribuição é exaurido (CHARTERED INSTITUTE OF LIBRARY AND INFORMATION PROFESSIONALS, 2014). Em outras palavras, o direito

\footnotetext{
${ }^{6}$ URL: http://www.dominiopublico.gov.br
} 
de exaustão determina que a pessoa que compra um livro pela primeira vez é dona daquele objeto (cópia impressa do livro) e pode emprestá-lo ou revendê-lo para outra pessoa, mas não copiá-lo (IFLA, 2014). É esse princípio que permite que as bibliotecas determinem como será o empréstimo dos materiais comprados por ela (IFLA, 2014).

Mas ainda há divergências sobre como, e se, esse princípio pode ser aplicado aos livros eletrônicos e a outros documentos digitais. A IFLA (2014) destaca dois casos importantes relacionados a essa questão. No primeiro caso, o Tribunal de Justiça da União Europeia decidiu em 03 de julho 2012, no litígio da Oracle versus UsedSoftware (C-128/11), que o princípio da exaustão após a primeira venda pode ser aplicado aos programas de computador, mas não necessariamente isso acontecerá com outros trabalhos protegidos pelo direito autoral. Quando um trabalho é apenas licenciado pelo detentor dos seus direitos não há transferência de propriedade e, portanto, a exaustão não se aplica. Mas se o arquivo digital é vendido e o comprador tem posse desse arquivo, o princípio da exaustão se aplica e o documento pode ser emprestado, revendido ou doado sem necessidade de autorização prévia do detentor dos direitos. Entretanto, mudanças na legislação podem alterar esse entendimento (IFLA, 2014).

O segundo caso é de uma corte do distrito sul de Nova Iorque, nos Estados Unidos. O caso buscava verificar a legalidade do sistema ReDigi para revenda de arquivos de música digital. Esse sistema funcionava de maneira que existia apenas um arquivo com a música. Então se a música estava no sistema ela não existia mais no computador de quem a enviou. O juiz decidiu que essa revenda não estava de acordo com a "First Sale Doctrine" já que ela é limitada a objetos materiais e esse sistema revendia o código do arquivo digital, e não o meio físico onde ele foi obtido originalmente (o HD do computador). Nesse caso, a questão chave é decidir sobre a legalidade de distribuir uma nova cópia de um arquivo quando o original é destruído. Para tanto, é necessária uma mudança na lei de direito autoral (IFLA, 2014).

Sobre outro caso, o Tribunal Alemão do Distrito de Bielefeld decidiu, em abril de 2013, que os livros eletrônicos e os audiolivros não podem ser revendidos porque, diferentemente dos trabalhos físicos, eles não estão sujeitos à exaustão dos direitos autorais (CHARTERED INSTITUTE OF LIBRARY AND INFORMATION PROFESSIONALS, 2014).

É possível perceber que ainda existem muitas divergências no direito internacional sobre o que pode ser feito com os livros eletrônicos depois da sua compra. Por isso, é necessário que haja uma legislação específica e atualizada sobre o assunto, que deve ser extremamente clara, e deve levar em conta os aspectos inerentes aos arquivos digitais. 
As bibliotecas, assim como os sebos, não foram formalmente legalizadas no Brasil. O que legaliza o seu funcionamento nos Estados Unidos é a "First Sale Doctrine”, que não existe aqui.

Apesar de ainda não possuir legislação específica de direito autoral para as bibliotecas, o Brasil assinou em 2013 o Tratado de Marrakech ${ }^{7}$, que permite que livros sejam adaptados para Braille e áudio sem necessidade de autorização prévia, permitindo a sua acessibilidade para deficientes. Esse tratado é válido no Brasil, pois tratados possuem força de lei depois de serem aprovados pelo Congresso Nacional.

No âmbito internacional, a Organização Mundial de Propriedade Intelectual (OMPI, ou WIPO em inglês), começou a trabalhar formalmente em uma proposta de tratado de limitações e exceções para bibliotecas e arquivos (TLIB) em novembro de 2011. Se algumas dessas cláusulas forem incorporadas a um tratado internacional da OMPI elas terão o potencial de influenciar os acordos das licenças de livros eletrônicos (CHARTERED INSTITUTE OF LIBRARY AND INFORMATION PROFESSIONALS, 2014). A IFLA está envolvida nessa iniciativa e mais informações podem ser encontradas em sua página na Internet ${ }^{8}$. Em março de 2015 ainda não se havia chegado a nenhuma conclusão sobre o tratado.

A questão da legalidade e respeito às normas relativas ao direito autoral sempre esteve presente nas bibliotecas. Antes, a preocupação era com as cópias, por exemplo, com a quantidade de páginas que poderiam ser copiadas pelos usuários e com os documentos que os bibliotecários poderiam enviar por correio quando solicitados. Hoje, juntam-se a essas preocupações outras relativas ao conteúdo digital, principalmente quando se leva em conta a facilidade de cópia e disseminação de arquivos completos por esse meio.

Por isso foi criada a Gestão de Direitos Digitais (GDD), mais conhecida pela sigla em inglês DRM (Digital Rights Management). O DRM impõe o respeito às leis de direito autoral por meio de artifícios tecnológicos que impedem a cópia dos arquivos. A nosso ver ele é condenável, pois normalmente quem comete um crime é punido depois de cometê-lo, e não antes. Além disso, as restrições do DRM podem ir além do que é exigido pela lei, colocando a vontade do vendedor antes daquela do cliente e impedindo que se faça o que quiser com o material adquirido, ainda que dentro da lei.

Na prática, o DRM supervisiona o que o usuário pode fazer com o arquivo do livro eletrônico. Ele é um software que controla se é possível fazer cópias, a permissão para fazer

\footnotetext{
${ }^{7}$ Disponível aqui em espanhol: http://www.wipo.int/treaties/es/text.jsp?file_id=302979

${ }^{8}$ URL: http://www.ifla.org/copyright-tlib
} 
mudanças e o fim do acesso ao arquivo depois de um tempo determinado, função muito utilizada por bibliotecas. As limitações variam de acordo com quem produziu o livro eletrônico, o programa e o aparelho utilizado para leitura (DOUCETTE; LEWONTIN, 2012).

O DRM também limita quantas páginas de uma obra podem ser impressas pelo leitor. Essa quantidade de páginas é uma decisão arbitrária de quem programa o DRM já que a lei de direitos autorais não determina exatamente quantas páginas podem ser copiadas ou impressas por livro. Além disso, a biblioteca não possui controle sobre o DRM do vendedor e por isso deve analisar as limitações colocadas na licença de venda, já que o DRM é parte dela, para avaliar se essas limitações permitem ou não o uso satisfatório da obra (ALBITZ; BRENNAN, 2012).

\subsection{EXPERIÊNCIAS DE OUTRAS BIBLIOTECAS COM LIVROS ELETRÔNICOS}

O Instituto Cervantes é uma instituição pública criada pela Espanha em 1991 para promover o ensino, o estudo e o uso do espanhol, e difundir a cultura hispânica. O Instituto Cervantes conta com 76 centros distribuídos por 33 países em quatro continentes, e a sua rede de bibliotecas (RBIC) possui 61 unidades (COLMENERO NIÑO, 2013).

A seleção, aquisição, gestão e manutenção dos livros eletrônicos são feitas de forma centralizada, pelo Departamento de Bibliotecas y Documentación, que fica em Madri. A compra dos livros eletrônicos segue a mesma política de desenvolvimento de coleções que já existia (COLMENERO NIÑO, 2013).

A seleção dos livros é feita diretamente com livreiros e editoras, e a escolha dos livros não é feita por pacotes (COLMENERO NIÑO, 2013). Além disso, os livros são comprados, e não assinados. São adquiridos os direitos de exploração, protegendo o conteúdo no caso de livros com direito de autor, administrando e gerenciando diretamente os arquivos (COLMENERO NIÑO, 2013).

A biblioteca digital do Instituto Cervantes é composta por recursos informacionais, audiolivros e livros eletrônicos que estão disponíveis para qualquer usuário com carteirinha pela sua página da Internet (COLMENERO NIÑO, 2013).

Existem três modalidades de acesso ao material:

a) Download livre de materiais publicados pela instituição e títulos livres de direitos autorais: o usuário pode fazer o download de tantos títulos quantos desejar para o seu dispositivo. 
b) Empréstimo de livros protegidos pelo direito autoral, com proteção anticópia com DRM, que permite o download em diferentes dispositivos, emprestar um livro por um período determinado e fazer reservas.

c) Leitura e visualização em streaming para obras que podem ser lidas ou vistas online, como os contos em vídeo, e também possuem um prazo limitado de empréstimo.

Para os materiais com direito autoral vigente é utilizado o DRM da Adobe Content Server e o streaming. A leitura por streaming exige que a pessoa esteja sempre conectada à Internet, já que o material vai sendo carregado conforme é visualizado. Colmenero Niño (2013) defende que o streaming é mais seguro, pois o usuário não faz download do conteúdo, e assim o sistema protege os direitos autorais e outros direitos do titular do conteúdo, controla os acessos e mantém um controle contínuo da obra, regula o tempo de empréstimo e facilita a leitura do conteúdo protegido.

O empréstimo dos livros eletrônicos é feito através da plataforma Odilo TK, da empresa OdiloTID, desenvolvida com a tecnologia Google Web Toolkit (GWT) em um sistema similar ao Overdrive, que é muito utilizado em bibliotecas dos EUA. Esse sistema funciona na nuvem (cloud computing) e para seu uso é necessário ter um dispositivo com um aplicativo para leitura instalado e uma conexão com a Internet. A plataforma é compatível com a maioria dos dispositivos disponíveis no mercado, sejam eles computadores, tablets, e-readers ou smartphones, funciona com qualquer navegador de Internet e não necessita de plugins adicionais (COLMENERO NIÑO, 2013).

\subsection{CONCLUSÕES DA REVISÃO DE LITERATURA}

A partir da literatura analisada foi possível observar a grande variedade de modelos de negócios disponíveis para as bibliotecas para a aquisição de livros em formato eletrônico. Cada um desses modelos possui características próprias que fazem com que eles não sejam melhores ou piores que os outros, mas apenas mais ou menos adequados às necessidades de cada biblioteca.

Cada uma das características e modelos apresentados podem ser livremente combinados com outros, dependendo apenas da disponibilidade do fornecedor. Assim, uma biblioteca pode comprar seus livros de um agregador, selecionando por pacote, com uma assinatura anual que permite o acesso de um número ilimitado de usuários enquanto outra compra de uma editora, selecionando por título, com acesso perpétuo para apenas um usuário por vez para cada livro. 
Essa flexibilidade permite que bibliotecas grandes e pequenas, com altos ou baixos orçamentos, possam adquirir livros digitais de acordo com as suas necessidades.

$\mathrm{Na}$ escolha do vendedor é possível escolher entre editoras, que podem oferecer maiores descontos e flexibilidade no acesso, mas possuem a desvantagem de oferecerem apenas os livros da própria editora; entre agregadores, que reúnem editoras em uma única plataforma de acesso com um custo um pouco maior e com menor possibilidade de negociação. Também é possível escolher os distribuidores, que reúnem editoras e agregadores, unificando o processo de compra, mas que podem não oferecer todos os títulos das editoras.

É provável que um único vendedor não consiga oferecer tudo o que a biblioteca necessita. Nesse caso será necessário comprar de diferentes vendedores. Na pesquisa realizada por Vasileiou, Rowley e Hartley (2012) com bibliotecas universitárias, houve bibliotecas que compraram de 26 vendedores diferentes, e todas as sete bibliotecas da pesquisa compraram tanto de editoras quanto de agregadores. Além disso, todas as sete bibliotecas da pesquisa (VASILEIOU; ROWLEY; HARTLEY, 2012) usaram simultaneamente a seleção por título e por pacote para a compra de livros completos (e não de capítulos).

A seleção dos livros para compra pode ser feita por título, o que exige mais trabalho do bibliotecário, ou por pacotes que são divididos por assuntos e que incluem títulos previamente selecionados pelo vendedor. A compra por pacotes costuma oferecer maiores descontos, mas pode incluir títulos desatualizados ou de menor interesse para a biblioteca. Outra facilidade oferecida para as bibliotecas no momento da seleção são os planos de aprovação, modelo no qual os livros são primeiramente disponibilizados para a biblioteca que então decide se quer comprá-los ou não, mas que exige atenção para evitar a compra de títulos indesejados.

Os modelos de negócio incluem o acesso perpétuo, que é o mais similar à compra de livros em papel, pois garante que a biblioteca sempre terá acesso ao livro comprado. A desvantagem desse modelo é que depois da compra a biblioteca sempre terá gastos com a manutenção do material adquirido, caso ela decida pagar pela plataforma do vendedor ou caso ela decida ela mesma cuidar da preservação e disponibilização do material.

Outro modelo de negócio muito comum é a assinatura, onde a biblioteca apenas paga pelo direito de acesso ao livro por um período determinado. Sua vantagem é que o preço por título é menor que o do acesso perpétuo, sendo indicado para livros que a biblioteca não pretende ter para sempre em seu acervo. A assinatura também pode oferecer a troca de títulos, onde depois de certo período existe a possibilidade de trocar títulos pouco utilizados por outros que serão mais úteis. $\mathrm{E}$ a assinatura também pode ser acompanhada por um limite de número 
de acessos por título, que determina que um título apenas possa ser acessado certo número de vezes antes de se tornar indisponível para o usuário, e fica indisponível até que a biblioteca pague uma nova taxa de acesso.

O empréstimo de curto prazo é um modelo de negócio no qual a biblioteca deixa certa quantia disponível e os usuários, através do uso, decidem quais títulos serão alugados pela biblioteca. Ao escolher esse modelo a biblioteca pode impor certos limites, como um valor máximo para o aluguel dos livros. A sua principal vantagem é que a escolha do aluguel dos títulos cabe a quem realmente vai utilizá-los.

A aquisição orientada pelo usuário é um modelo similar ao empréstimo de curto prazo. A diferença é que ao atingir um número de acessos determinado pela biblioteca, o título é automaticamente adquirido. A vantagem desse modelo é que os títulos mais utilizados são automaticamente adquiridos, evitando que os gastos com o aluguel ultrapassem o valor da compra.

Os modelos de acesso definem como será na prática o acesso dos usuários aos livros. Se apenas um usuário pode acessar o livro por vez, isso significa que outros podem ser frustrados por terem o acesso ao material adquirido negado. $\mathrm{O}$ acesso de usuários múltiplos pode resolver esse problema, mas se existe dificuldade para calcular quantos usuários acessam o exemplar por vez o ideal é o acesso ilimitado, que permite que todos visualizem o mesmo livro ao mesmo tempo.

O meio de acesso define se o livro pode ser consultado apenas online, o que exige uma conexão constante com a Internet, ou se o download do livro será permitido, possibilitando assim a sua leitura off-line. Quando o download do livro é permitido seu empréstimo costuma ser controlado por DRM, que é um programa que controla, entre outras coisas, o período durante o qual o arquivo pode ser acessado.

A licença de venda é a parte mais importante da compra do ponto de vista legal. Nela devem constar os termos definidos durante a compra, os direitos da biblioteca e os deveres do vendedor.

Apesar de não sofrerem com o desgaste físico e por isso não precisarem ser descartados, quando os livros eletrônicos são adquiridos por meio de assinatura é necessário decidir se eles serão renovados ou cancelados, o que exige uma política parecida com a de descarte.

Para buscar uma união que leve à economia de recursos das bibliotecas surgiram várias alternativas diferentes pelo mundo: no Canadá as bibliotecas decidiram se unir em um consórcio para criar a sua própria plataforma; na Europa as bibliotecas se uniram em uma campanha para 
reivindicar seus direitos e na Dinamarca, na Holanda e na Alemanha a solução encontrada foi o governo criar a sua própria plataforma de livros eletrônicos.

O gerenciamento de livros eletrônicos em bibliotecas é um processo complexo e precisa evoluir principalmente na negociação das licenças, no marketing e promoção, no treinamento de usuários, na monitoração e avaliação do uso e nas práticas de renovação e cancelamento (VASILEIOU; ROWLEY; HARTLEY, 2012).

A aquisição de livros eletrônicos para uma biblioteca brasileira ainda é algo confuso e com inúmeros detalhes técnicos (hardware, software, financeiros e direitos autorais). Similar aos contextos dos países desenvolvidos, a biblioteca brasileira também passará por enormes avanços no fornecimento desse tipo de conteúdo aos seus usuários. Ressalta-se também que vemos a necessidade das nossas entidades bibliotecárias buscarem a modernização e simplificação dos processos de aquisição na área pública - as normas contábil e financeira ainda estão voltadas para o contexto do livro impresso. Também é necessária a modernização dos órgãos que fiscalizam as bibliotecas, como o Ministério da Educação, que ainda não possui uma política clara para aceitar os exemplares eletrônicos como parte do acervo na avaliação para dar nota aos cursos. O livro eletrônico é irreversível, portanto, os bibliotecários precisam conhecer todas as facetas envolvidas na aquisição desse novo tipo de formato bibliográfico. 


\section{METODOLOGIA}

Esta pesquisa possui natureza descritiva. A pesquisa descritiva é aquela onde se tenta descrever características do fenômeno central da pesquisa. Ela é feita para determinar e descrever as características das variáveis de interesse de uma situação. O objetivo da pesquisa descritiva é descrever aspectos relevantes do fenômeno central da pesquisa. Pesquisas descritivas que apresentam seus dados de maneira significativa nos ajudam a entender as características de um grupo em uma dada situação, pensar sistematicamente sobre aspectos de uma situação, oferecer ideias para serem examinadas posteriormente e ajudar a tomar decisões simples (SEKARAN, 2003, p. 119).

O fenômeno central a ser descrito nessa pesquisa são os modelos de venda de livros eletrônicos para bibliotecas. Foram determinadas e descritas as características e os aspectos relevantes que cercam esse processo. Seus dados foram apresentados de maneira significativa para ajudar a pensar sistematicamente sobre esse fenômeno e colaborar na tomada de decisão relacionada a esse assunto.

A abordagem metodológica da pesquisa foi qualitativa. De acordo com Creswell (2010) os procedimentos da pesquisa qualitativa se baseiam em dados de texto. Inicialmente, foi feita uma revisão de literatura para delimitar o marco teórico. Além disso, a pesquisa qualitativa segue as seguintes características: é feita em ambiente natural, pois os dados são coletados por meio de conversas diretas, sem nenhum controle sobre o ambiente, e no local em que os participantes vivenciam o problema que está sendo estudado. $\mathrm{O}$ local de coleta dos dados foram as bibliotecas que adquiriram livros eletrônicos. O pesquisador foi instrumento fundamental da pesquisa, já que as entrevistas foram feitas individualmente. Os dados foram extraídos de múltiplas fontes, como entrevistas e documentos, e depois foram examinados. A análise de dados foi indutiva, já que foram criados padrões e categorias próprios para organizar os dados. O processo de pesquisa foi emergente, já que o plano inicial não era rígido e mudou de acordo com a coleta de dados. O objetivo principal foi aprender sobre o problema, e por isso a pesquisa se moldou para obter essas informações. A pesquisa foi uma investigação interpretativa, pois o pesquisador fez uma interpretação do que enxergou, ouviu e entendeu. E essas interpretações estão diretamente ligadas ao conhecimento prévio do pesquisador. E o relato foi amplo, abrangendo várias perspectivas do problema.

Esta pesquisa possui natureza básica ou fundamental, pois busca gerar um corpo de conhecimento ao tentar entender como o problema pode ser solucionado. Suas descobertas contribuem para a construção do conhecimento que depois pode ser utilizado para a solução de 
problemas organizacionais. No caso, os problemas de bibliotecas que pretendem comprar livros eletrônicos. O objetivo principal da pesquisa básica é gerar mais conhecimento e entendimento sobre a questão de interesse, e construir teorias baseadas nos resultados. Consequentemente, essas teorias são a base para outros estudos sobre os vários aspectos do fenômeno (SEKARAN, 2003). O relatório final da pesquisa inclui uma análise dos modelos de comercialização de livros eletrônicos para bibliotecas.

O método de pesquisa utilizado foi o levantamento. O levantamento é utilizado para determinar o estado atual de um fenômeno. Ele parte do princípio que, ao se seguir cuidadosamente certos procedimentos científicos, é possível fazer inferências sobre um grupo estudando apenas uma parte dele. O grupo completo é conhecido como população, e deve ser cuidadosamente escolhido e claramente definido e delimitado. A parte do grupo que é efetivamente estudada é conhecida como amostra. As observações feitas durante a pesquisa de levantamento geram dados ou informações (CONNAWAY; POWELL, 2010).

Neste estudo o levantamento foi utilizado para determinar o estado atual dos modelos de comercialização de livros eletrônicos para bibliotecas. A população nesse caso é formada pelas bibliotecas do Distrito Federal que compraram livros eletrônicos.

Babbie (1999) afirma que levantamentos são muito semelhantes a censos, com a diferença de que os censos examinam toda a população enquanto o levantamento examina apenas uma amostra. A pesquisa de levantamento é utilizada para entender não somente a amostra, mas toda a população maior de onde a amostra foi selecionada.

Para esse estudo foram escolhidas as bibliotecas do Distrito Federal devido à proximidade geográfica com a Universidade onde a pesquisa é realizada. O DF tem características únicas e especiais por reunir muitos órgãos públicos federais na mesma cidade. Mesmo que essa realidade não seja replicada em outros estados, os aspectos gerais da aquisição dos livros eletrônicos serão os mesmos em qualquer lugar.

O tipo de amostragem foi intencional já que existem poucas bibliotecas no DF que compraram livros eletrônicos e que por isso considerou-se como teoricamente possível que a pesquisa fosse realizada em todas elas. Então, de acordo com Connaway e Powell (2010, p. 128) que consideram que o tamanho ideal da amostra é "quanto maior melhor", o objetivo foi entrevistar o maior número possível de bibliotecas do DF que se sabia que haviam comprado livros eletrônicos.

Apesar da amostragem intencional não ser ideal em casos onde a população é grande, nesse caso, como o universo é limitado e claramente identificável, ela se mostra como o método de amostragem ideal para essa pesquisa. De acordo com Babbie (1999, p. 153) é possível 
"selecionar a amostra baseado no conhecimento da população e dos seus elementos, e da natureza das metas de pesquisa".

A técnica a utilizada para a coleta de dados foi a entrevista, para obter informações singulares dos entrevistados, coletar informações de muitas pessoas e descobrir o que não pode ser observado pelos pesquisadores (STAKE, 2011). Assim foi possível conhecer as experiências de pessoas que já participaram do processo de aquisição de livros eletrônicos para bibliotecas no Distrito Federal. A entrevista é a melhor técnica para a coleta desses dados já que a experiência, as dificuldades e as soluções encontradas nesse processo não podem ser observadas, pois ocorreram num momento anterior à pesquisa.

As entrevistas foram realizadas face a face, pessoalmente, um a um. Essa técnica permite controlar a linha de questionamento para que sejam obtidas as repostas desejadas de cada entrevistado. Uma desvantagem dessa técnica é que as respostas são diretamente influenciadas pelo ponto de vista do entrevistado. Além disso, cada entrevistado é diferente e pode ser bem articulado ou não ao expor suas ideias e opiniões (CRESWELL, 2010).

A principal vantagem da entrevista face a face é que o pesquisador pode adaptar as perguntas quando necessário, esclarecendo dúvidas e garantindo que as respostas foram entendidas corretamente, repetindo e reformulando as perguntas. O pesquisador também pode observar sinais não verbais do respondente. A desvantagem desse tipo de entrevista é que o respondente pode se sentir inseguro sobre o anonimato de suas respostas ao interagir cara a cara com o entrevistador (SEKARAN, 2003).

No momento da entrevista foram seguidas as recomendações de Sekaran (2003) que diz que os pesquisadores devem estabelecer uma conexão com os respondentes e motivá-los a dar respostas livres de influências, reduzindo qualquer suspeita, medo, ansiedade e preocupação que eles possam ter sobre a pesquisa e suas consequências. Isso pode ser alcançado se o pesquisador for sincero, agradável e se não fizer julgamentos. Ao entrevistar, o pesquisador deve começar com perguntas mais gerais e depois fazer perguntas específicas, fazer perguntas neutras, oferecer esclarecimentos quando necessário, e ajudar os respondentes com assuntos complexos. As respostas devem ser anotadas imediatamente e não confiadas apenas à memória. As entrevistas foram gravadas depois da assinatura da autorização dos respondentes para possibilitar a sua transcrição e facilitar a análise posterior dos dados.

A estratégia de entrevista utilizada é a semiestruturada, que permite enxergar o ponto de vista do entrevistado, além de permitir a improvisação e a flexibilidade (SILVERMAN, 2009). A estrutura feita previamente evita que assuntos importantes sejam esquecidos durante a entrevista. A experiência do entrevistador permite que as perguntas sejam adaptadas à 
entrevista e que surjam novas perguntas de acordo com a necessidade, para que as informações necessárias possam ser obtidas.

Entrevistas estruturadas são realizadas quando já se sabe quais informações se deseja obter no final. Baseado nas exigências da situação o pesquisador experiente pode se aproveitar de uma resposta para fazer outras perguntas relevantes que não estejam no formulário da entrevista. Nesse processo, podem ser identificados novos fatores, resultando em um maior entendimento (SEKARAN, 2003).

As entrevistas foram feitas com bibliotecários responsáveis pela compra de livros eletrônicos. Eles foram escolhidos por serem os principais interessados no assunto. A pesquisa não foi feita com os vendedores pois busca examinar a questão do ponto de vista dos compradores. Além disso, os vendedores não possuem disponibilidade para fornecer informações quando essa atenção não resultará em uma compra. A entrevista com os bibliotecários permite observar as condições reais de compra colocadas pelos vendedores, inclusive os detalhes que não são revelados em um primeiro momento e as percepções que se tem apenas depois da compra.

O pesquisador deve parar de fazer entrevistas quando um número suficiente de entrevistas já foi feito e foi obtida informação adequada para entender e descrever os fatores importantes da situação. A informação deve ser então tabulada e os dados analisados. Isso ajuda o pesquisador a alcançar os objetivos propostos, que no caso envolvem a descrição de um fenômeno (SEKARAN, 2003, p. 225).

A análise dos dados foi feita com uso do senso comum, analisando e sintetizando as informações (STAKE, 2011). A partir das transcrições das gravações das entrevistas os dados foram codificados e separados de acordo com critérios que foram estabelecidos durante a pesquisa pelo pesquisador, de acordo com a necessidade da pesquisa (CRESWELL, 2014). Depois, os dados foram reunidos de maneira que pudessem ser compreendidos, ganhando um novo significado. Sempre que possível foram feitos gráficos para facilitar a visualização dos resultados. Então, na interpretação dos dados, foram utilizados fragmentos, acompanhados por citações e reflexões sobre eles (STAKE, 2011). Além das transcrições, a análise dos dados também utilizou as anotações feitas durante a entrevista. Na interpretação também foram feitos contrastes e comparações dos dados obtidos (CRESWELL, 2014).

Esta pesquisa foi realizada de acordo com as questões éticas de pesquisa. Como defendem Israel e Hay (2006 apud CRESWELL, 2010, p. 116):

Os pesquisadores precisam proteger os participantes de sua pesquisa, desenvolver uma relação de confiança, promover a integridade da pesquisa, 
proteger-se contra conduta inadequada e impropriedades que possam refletir em suas organizações ou instituições, e enfrentar problemas novos e desafiadores.

De acordo com as recomendações de Creswell (2010), os participantes assinaram um formulário de consentimento informado antes das entrevistas. Esse formulário deve incluir os seguintes elementos de acordo com Sarantakos (2005 apud CRESWELL, 2010): identificar o pesquisador, a instituição patrocinadora, a forma de seleção dos participantes, o propósito da pesquisa, os benefícios da participação, o nível e tipo de envolvimento dos participantes, informação dos riscos aos participantes, garantia de confidencialidade e de que o participante pode se retirar da pesquisa a qualquer momento e fornecimento de nomes para contato caso surjam problemas. Assim, foi feita uma autorização por escrito para a gravação das entrevistas. O formulário utilizado nesta pesquisa consta do Apêndice D.

O propósito do estudo foi descrito com cuidado para os participantes para melhorar a colaboração e para estabelecer uma relação de confiança entre entrevistador e entrevistado (SARANTAKOS, 2005 apud CRESWELL, 2010). O patrocínio do estudo também foi esclarecido para estabelecer confiança e credibilidade ao instrumento de pesquisa (CRESWELL, 2010).

No processo de codificação dos dados os nomes dos indivíduos foram dissociados das suas respostas para proteger o anonimato (CRESWELL, 2010). O áudio das entrevistas, quando solicitado, foi enviado aos entrevistados para assegurar que eles concordam com o que foi dito e que não existem erros.

\subsection{UNIVERSO E AMOSTRA DA PESQUISA}

Para determinar o universo da pesquisa primeiro foi necessário identificar quais bibliotecas do DF já haviam comprado livros eletrônicos. Para encontrar essas bibliotecas foi utilizado o Guia de Bibliotecas da $1^{a}$ Região do Conselho Regional de Biblioteconomia (MARCIAL; GUIMARÃES, 2008). Desse documento foram retiradas diversas informações sobre as bibliotecas do DF, incluindo o número de instituições de cada tipo e os seus endereços de correio eletrônico. Por esse ser um documento de 2008, muitos endereços de correio eletrônico estavam desatualizados, algumas instituições podem ter deixado de existir e outras foram criadas. Entretanto, esse foi o documento mais completo encontrado sobre as bibliotecas 
do DF. Algumas informações foram obtidas em outras fontes, como, por exemplo, em páginas da Internet ou em conversas informais com outros bibliotecários. Todas as informações adicionais foram acrescentadas à pesquisa.

Para descobrir quais bibliotecas haviam comprado livros eletrônicos foi enviada uma mensagem para todos os correios eletrônicos de bibliotecas do DF que estavam no guia. Os $e$ mails foram enviados no dia 7 de maio de 2014 com as seguintes perguntas:

1. A sua biblioteca tem acesso a livros digitais?

2. Eles foram comprados?

3. Se não possui livros digitais, pretende comprar nos próximos 12 meses?

Essas perguntas foram feitas na intenção de descobrir se a biblioteca oferecia livros eletrônicos aos seus usuários, se eles haviam sido comprados ou obtidos de forma gratuita, e se a biblioteca pretendia comprar livros eletrônicos no período da pesquisa, se tornando objeto de estudo.

A pergunta número 1 era propositalmente ambígua, já que qualquer biblioteca que possua acesso à Internet através de um computador também possui acesso aos livros eletrônicos oferecidos de forma aberta e gratuita por sites como o Domínio Público. Essa possibilidade foi percebida apenas por três dos respondentes, que citaram os livros gratuitos.

Além desses, também existe a possibilidade de a biblioteca oferecer livros eletrônicos que foram produzidos pela própria instituição ou que foram recebidos por doação. Algumas instituições não consideraram os livros que fazem parte das bases de dados assinadas pela biblioteca como uma coleção de livros eletrônicos, já que essas coleções também incluem outros tipos de materiais.

As respostas começaram a chegar imediatamente e a última foi recebida em 25 de julho de 2014. Todas as outras respostas (menos a última) foram recebidas até 13 de maio de 2014, ou seja, em um período de seis dias.

A pesquisa encontrou um total 317 bibliotecas no DF, que podem ser vistas divididas de acordo com a sua classificação na tabela 1. 
Tabela 1 - Bibliotecas do DF

\begin{tabular}{|c|c|c|c|c|c|c|c|}
\hline Tipo & Quantidade & Sem e-mail & Com e-mail & $\begin{array}{c}\text { E-mail } \\
\text { inexistente }\end{array}$ & $\begin{array}{c}\text { E-mail } \\
\text { válido }\end{array}$ & Respondeu & $\begin{array}{c}\text { Não } \\
\text { respondeu }\end{array}$ \\
\hline $\begin{array}{c}\text { Escolar } \\
\text { Pública }\end{array}$ & 15 & 9 & 6 & 4 & 2 & 1 & 1 \\
\hline $\begin{array}{c}\text { Escolar } \\
\text { Privada }\end{array}$ & 58 & 11 & 47 & 21 & 26 & 1 & 25 \\
\hline $\begin{array}{c}\text { Universitária } \\
\text { Pública }\end{array}$ & 12 & 0 & 12 & 8 & 4 & 2 & 2 \\
\hline $\begin{array}{c}\text { Universitária } \\
\text { Privada }\end{array}$ & 47 & 4 & 43 & 21 & 22 & 4 & 18 \\
\hline Executivo & 88 & 5 & 83 & 19 & 64 & 26 & 38 \\
\hline Judiciário & 17 & 0 & 17 & 5 & 12 & 10 & 2 \\
\hline Legislativo & 6 & 0 & 6 & 0 & 6 & 3 & 3 \\
\hline ONGs & 31 & 3 & 28 & 6 & 22 & 8 & 14 \\
\hline Pública & 43 & 21 & 22 & 8 & 14 & 2 & 12 \\
\hline & 317 & 53 & 264 & 92 & 172 & 57 & 115 \\
\hline TOTAL & & & & & & & \\
\hline
\end{tabular}

Fonte: Autoria própria.

Desse total de 317 bibliotecas, não foram encontrados os endereços de correio eletrônico de 53 instituições. Dos 264 e-mails enviados, 92 retornaram uma mensagem de endereço inexistente. Esses números podem ser vistos no gráfico 1 a seguir.

Gráfico 1 - Total de bibliotecas encontradas

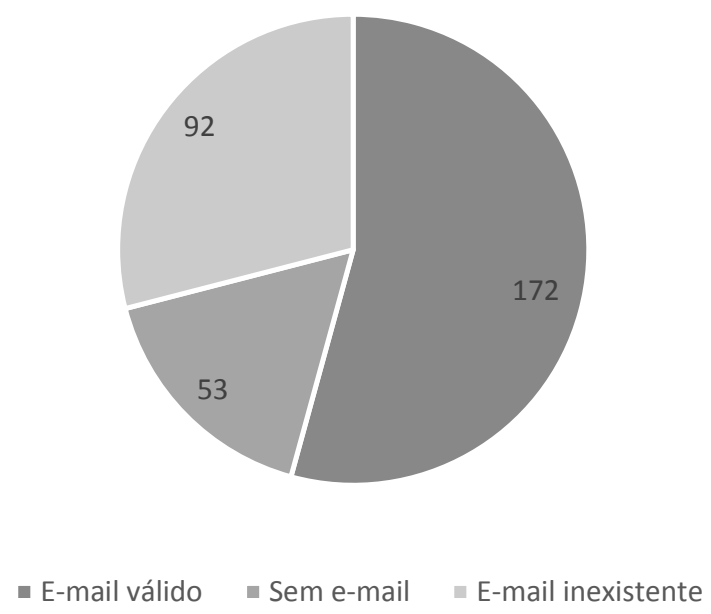

Fonte: Autoria própria. 
De um total de 172 e-mails enviados para endereços válidos, foram obtidas respostas de 57 instituições. O índice de resposta das mensagens enviadas para endereços válidos foi de apenas $33 \%$.

Com as respostas das três perguntas foi possível elaborar o quadro 5 a seguir, com a quantidade inicial de bibliotecas que já possuem e as que pretendem comprar livros eletrônicos.

Quadro 5-Respostas dos e-mails.

\begin{tabular}{|c|c|c|c|c|c|c|c|c|}
\hline & Tipo & Possui & Não possui & Comprou & Não comprou & Vai comprar & $\begin{array}{l}\text { Não vai } \\
\text { comprar }\end{array}$ & $\begin{array}{c}\text { Universo da } \\
\text { pesquisa }\end{array}$ \\
\hline 1 & Escola Pública & & $\mathrm{X}$ & & & & $\mathrm{X}$ & \\
\hline 2 & Escola Privada & $\mathrm{X}$ & & & $\mathrm{X}$ & $\mathrm{X}$ & & 1 \\
\hline 3 & Univ. Pública & & $\mathrm{X}$ & & & & $\mathrm{X}$ & \\
\hline 4 & Univ. Pública & & $\mathrm{X}$ & & & $\mathrm{X}$ & & 2 \\
\hline 5 & Univ. Privada & $\mathrm{X}$ & & $\mathrm{X}$ & & & & 3 \\
\hline 6 & Univ. Privada & $\mathrm{X}$ & & $\mathrm{X}$ & & & & 4 \\
\hline 7 & Univ. Privada & $\mathrm{X}$ & & $\mathrm{X}$ & & & & 5 \\
\hline 8 & Univ. Privada & & $\mathrm{X}$ & & & $\mathrm{X}$ & & 6 \\
\hline 9 & Executivo & & $\mathrm{X}$ & & & & $\mathrm{X}$ & \\
\hline 10 & Executivo & $\mathrm{X}$ & & $\mathrm{X}$ & & $\mathrm{X}$ & & 7 \\
\hline 11 & Executivo & & $\mathrm{X}$ & & & & $\mathrm{X}$ & \\
\hline 12 & Executivo & & $\mathrm{X}$ & & & & $\mathrm{X}$ & \\
\hline 13 & Executivo & $\mathrm{X}$ & & & $\mathrm{X}$ & & $\mathrm{X}$ & \\
\hline 14 & Executivo & $\mathrm{X}$ & & $\mathrm{X}$ & & & & 8 \\
\hline 15 & Executivo & & $\mathrm{X}$ & & & & $\mathrm{X}$ & \\
\hline 16 & Executivo & & $\mathrm{X}$ & & & & $\mathrm{X}$ & \\
\hline 17 & Executivo & $\mathrm{X}$ & & & $\mathrm{X}$ & & $\mathrm{X}$ & \\
\hline 18 & Executivo & & $\mathrm{X}$ & & & & $\mathrm{X}$ & \\
\hline 19 & Executivo & & $\mathrm{X}$ & & & & $\mathrm{X}$ & \\
\hline 20 & Executivo & $\mathrm{X}$ & & & $\mathrm{X}$ & & $\mathrm{X}$ & \\
\hline 21 & Executivo & & $\mathrm{X}$ & & & & $\mathrm{X}$ & \\
\hline 22 & Executivo & & $\mathrm{X}$ & & & & $\mathrm{X}$ & \\
\hline 23 & Executivo & & $\mathrm{X}$ & & & & $\mathrm{X}$ & \\
\hline 24 & Executivo & & $\mathrm{X}$ & & & & $\mathrm{X}$ & \\
\hline 25 & Executivo & & $\mathrm{X}$ & & & & $\mathrm{X}$ & \\
\hline 26 & Executivo & $\mathrm{X}$ & & & $\mathrm{X}$ & & $\mathrm{X}$ & \\
\hline 27 & Executivo & & $\mathrm{X}$ & & & & $\mathrm{X}$ & \\
\hline 28 & Executivo & & $\mathrm{X}$ & & & & $\mathrm{X}$ & \\
\hline 29 & Executivo & $\mathrm{X}$ & & & $\mathrm{X}$ & & $\mathrm{X}$ & \\
\hline 30 & Executivo & & $\mathrm{X}$ & & & $\mathrm{X}$ & & 9 \\
\hline 31 & Executivo & & $\mathrm{X}$ & & & & $\mathrm{X}$ & \\
\hline 32 & Executivo & & $\mathrm{X}$ & & & & $\mathrm{X}$ & \\
\hline 33 & Executivo & & $\mathrm{X}$ & & & & $\mathrm{X}$ & \\
\hline 34 & Executivo & $X$ & & & $\mathrm{X}$ & & $\mathrm{X}$ & \\
\hline 35 & Judiciário & & $\mathrm{X}$ & & & & $\mathrm{X}$ & \\
\hline 36 & Judiciário & $\mathrm{X}$ & & & $\mathrm{X}$ & $\mathrm{X}$ & & 10 \\
\hline 37 & Judiciário & & $\mathrm{X}$ & & & $\mathrm{X}$ & & 11 \\
\hline
\end{tabular}




\begin{tabular}{|c|c|c|c|c|c|c|c|c|}
\hline & Tipo & Possui & Não possui & Comprou & Não comprou & Vai comprar & $\begin{array}{c}\text { Não vai } \\
\text { comprar }\end{array}$ & $\begin{array}{c}\text { Universo da } \\
\text { pesquisa }\end{array}$ \\
\hline 38 & Judiciário & $\mathrm{X}$ & & $\mathrm{X}$ & & $\mathrm{X}$ & & 12 \\
\hline 39 & Judiciário & & $\mathrm{X}$ & & & & $\mathrm{X}$ & \\
\hline 40 & Judiciário & $\mathrm{X}$ & & $\mathrm{X}$ & & & & 13 \\
\hline 41 & Judiciário & & $\mathrm{X}$ & & & $\mathrm{X}$ & & 14 \\
\hline 42 & Judiciário & & $\mathrm{X}$ & & & $\mathrm{X}$ & & 15 \\
\hline 43 & Judiciário & $\mathrm{X}$ & & $\mathrm{X}$ & & & & 16 \\
\hline 44 & Judiciário & & $\mathrm{X}$ & & & & $\mathrm{X}$ & \\
\hline 45 & Legislativo & $\mathrm{X}$ & & & $\mathrm{X}$ & $\mathrm{X}$ & & 17 \\
\hline 46 & Legislativo & $X$ & & $\mathrm{X}$ & & & & 18 \\
\hline 47 & Legislativo & $\mathrm{X}$ & & $\mathrm{X}$ & & $\mathrm{X}$ & & 19 \\
\hline 48 & ONGs & & $\mathrm{X}$ & & & & $\mathrm{X}$ & \\
\hline 49 & ONGs & $\mathrm{X}$ & & $\mathrm{X}$ & & & & 20 \\
\hline 50 & ONGs & & $\mathrm{X}$ & & & & $\mathrm{X}$ & \\
\hline 51 & ONGs & $\mathrm{X}$ & & $\mathrm{X}$ & & & & 21 \\
\hline 52 & ONGs & & $\mathrm{X}$ & & & & $\mathrm{X}$ & \\
\hline 53 & ONGs & $\mathrm{X}$ & & & $\mathrm{X}$ & & $\mathrm{X}$ & \\
\hline 54 & ONGs & $\mathrm{X}$ & & $\mathrm{X}$ & & & & 22 \\
\hline 55 & ONGs & $\mathrm{X}$ & & $\mathrm{X}$ & & & & 23 \\
\hline 56 & Pública & & $X$ & & & & $\mathrm{X}$ & \\
\hline 57 & Pública & & $\mathrm{X}$ & & & & $\mathrm{X}$ & \\
\hline & TOTAL & 24 & 33 & 14 & 10 & 12 & 34 & \\
\hline
\end{tabular}

Fonte: Autoria própria.

A relação entre as bibliotecas respondentes que possuem e que não possuem livros eletrônicos pode ser vista no gráfico 2 a seguir:

Gráfico 2 - Bibliotecas que têm livros eletrônicos

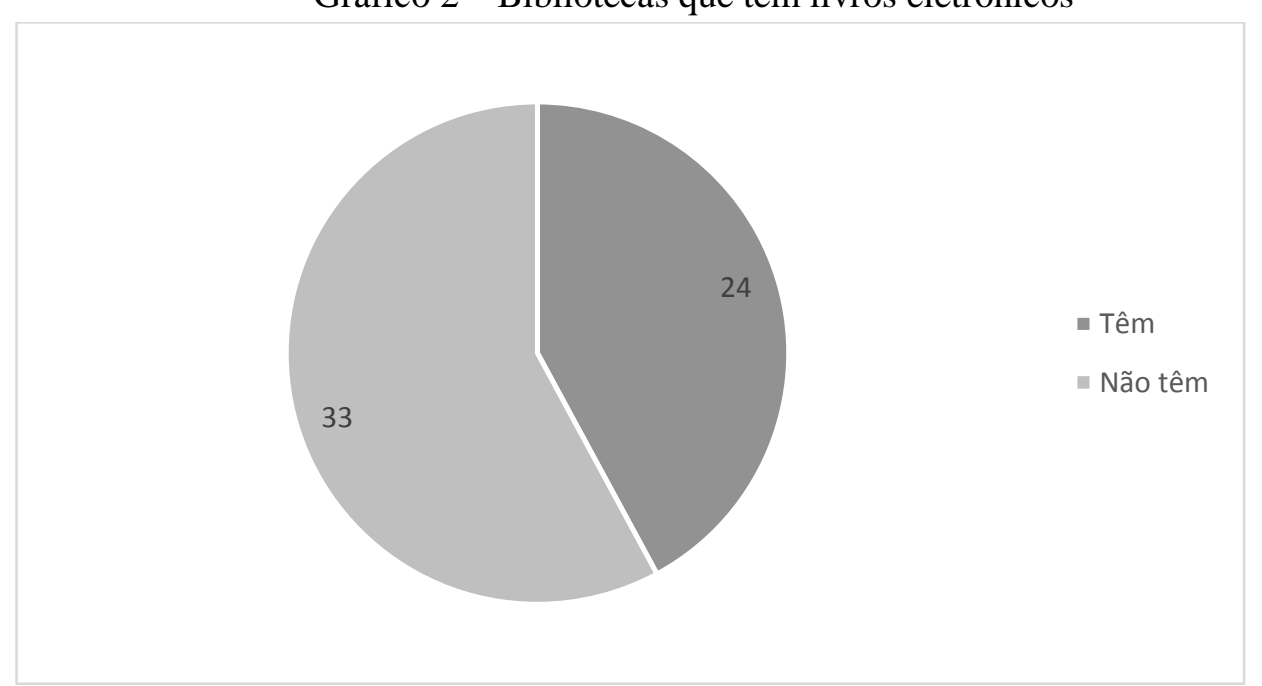

Fonte: Autoria própria. 
Dentre as 24 bibliotecas que possuem livros eletrônicos, a maioria possui livros que foram comprados, como consta no gráfico 3:

Gráfico 3 - Bibliotecas compraram livros eletrônicos

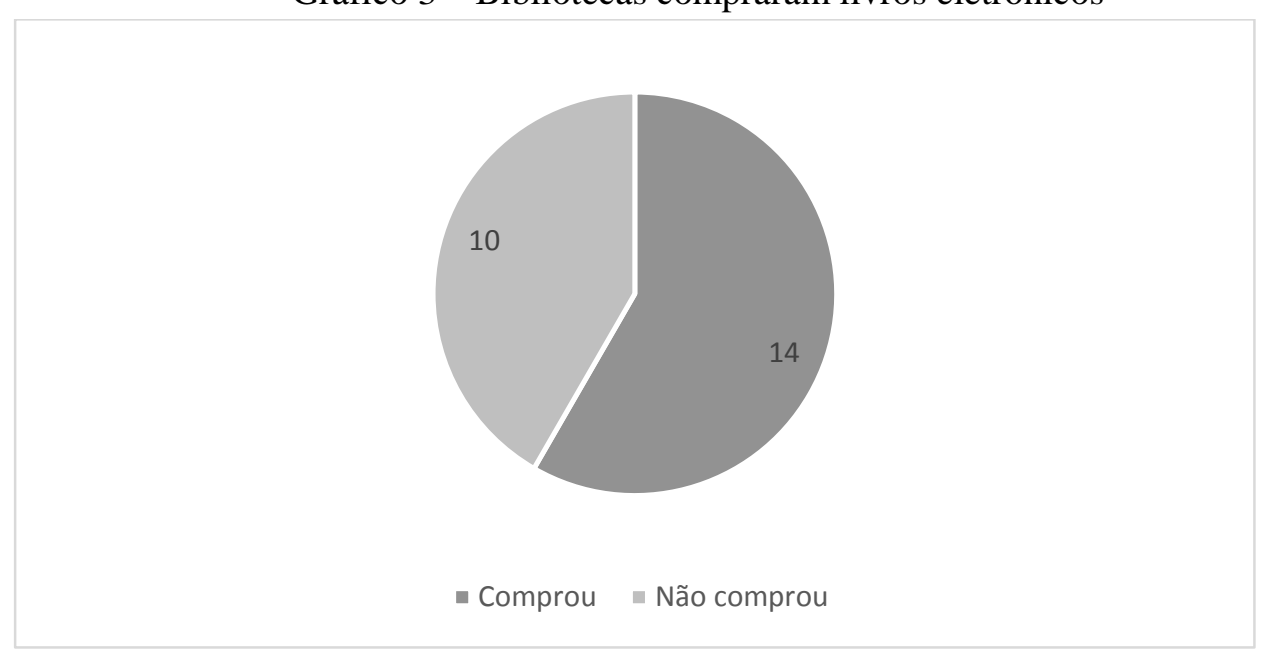

Fonte: Autoria própria.

A coleta de dados para a pesquisa começou em maio de 2014, com o levantamento por e-mail, para identificar quais bibliotecas já haviam comprado livros eletrônicos. A primeira entrevista nas bibliotecas foi feita em 31 de julho de 2014, e a última em 18 de setembro de 2015. O universo esperado para a pesquisa depois do levantamento feito por $e$-mail era de 23 bibliotecas. Uma outra biblioteca, que não respondeu a pesquisa por $e$-mail, já havia comprado livros eletrônicos e foi incluída na pesquisa, somando, assim, 24 bibliotecas. Mas o universo foi menor que o previsto pois muitas que tinham a intenção de comprar livros eletrônicos acabaram desistindo. A lista dessas bibliotecas consta no Apêndice E.

Antes de cada entrevista foi feito contato por telefone para confirmar a compra dos livros e agendar um horário. As bibliotecas apresentadas no quadro 6 são aquelas que haviam informado na pesquisa prévia realizada por e-mail que pretendiam comprar livros eletrônicos no período de um ano, mas, por alguma razão, não compraram. Como os e-mails foram enviados em maio de 2014, esse período seria entre maio de 2014 e maio de 2015.

No quadro 6 também é possível observar um breve resumo dos motivos informados pelas bibliotecas para não terem comprado livros eletrônicos. As respostas do quadro 6 foram obtidas por telefone. 
Quadro 6-Bibliotecas que desistiram de comprar livros eletrônicos

\begin{tabular}{|c|c|c|}
\hline & Tipo de biblioteca & Motivo da desistência \\
\hline 1 & Escola privada & $\begin{array}{l}\text { Só comprou Kindle e não comprou nenhum } \\
\text { livro. }\end{array}$ \\
\hline 2 & Universidade pública & Ainda não comprou por falta de verba. \\
\hline 3 & Especializada (executivo público) & $\begin{array}{l}\text { Tem um processo aberto, mas ainda não } \\
\text { comprou. }\end{array}$ \\
\hline 4 & Especializada (judiciário público) & $\begin{array}{l}\text { O mercado está incipiente, não atende às } \\
\text { necessidades informacionais dos usuários. } \\
\text { Por isso ainda não comprou e não pretende } \\
\text { comprar no ano que vem. }\end{array}$ \\
\hline 5 & Especializada (Legislativo público) & Só comprou bases de periódicos. \\
\hline 6 & Especializada (Legislativo público) & Só comprou bases de periódicos. \\
\hline 7 & Especializada (judiciário público) & $\begin{array}{l}\text { Ainda não comprou porque o orçamento está } \\
\text { reduzido e porque não tem uma biblioteca } \\
\text { digital. }\end{array}$ \\
\hline 8 & Especializada (judiciário público) & $\begin{array}{l}\text { A biblioteca tem a intenção de comprar, mas } \\
\text { o gestor do órgão ainda não autorizou que seja } \\
\text { feito o levantamento para a compra. }\end{array}$ \\
\hline 9 & Especializada (judiciário público) & Não foi informado. \\
\hline
\end{tabular}

Fonte: Autoria própria.

As bibliotecas 2 e 7 não puderam comprar por falta de verba. Esse foi um problema mencionado também por outros respondentes. O reflexo do atual cenário econômico do país pode ser visto claramente nas bibliotecas, que sofreram cortes em seus orçamentos.

A biblioteca 1 comprou apenas o aparelho Kindle, mas ainda não adquiriu nenhum livro eletrônico. O caso da biblioteca A, que será descrito ao longo da análise de dados, é similar, pois ela comprou um aparelho leitor de livros eletrônicos antes de comprar os livros.

A biblioteca 3 já tem um processo aberto, mas ainda não comprou nenhum livro eletrônico. A biblioteca 8 tem a intenção de comprar, mas antes precisa da autorização do gestor do órgão para fazer o levantamento.

A biblioteca 4 informou que ainda não comprou, pois, as opções disponíveis no mercado não pareceram satisfatórias para ela.

Além das nove bibliotecas do quadro 6, outras três bibliotecas possuem livros eletrônicos que foram comprados, mas a aquisição foi feita por uma sede que não está localizada em Brasília e, por isso a biblioteca daqui não possui informações suficientes sobre a compra. Uma dessas três bibliotecas foi visitada pela pesquisadora, mas por falta de informações não foi possível fazer a entrevista de acordo com o formulário e, finalmente foi decidido que a melhor opção seria não inclui-las na pesquisa por falta de informações sobre o tema.

Em outras duas bibliotecas, mesmo depois de muitas tentativas, não foi possível entrar em contato com o responsável pela aquisição para marcar a entrevista. Assim, de um total de 
24 bibliotecas do universo imaginado inicialmente para a pesquisa, restaram dez. Esses dados podem ser visualizados no quadro 7.

Quadro 7 - Universo da pesquisa

\begin{tabular}{|l|l|}
\hline Universo inicial & 24 \\
\hline Bibliotecas que não compraram & 9 \\
\hline Bibliotecas onde a compra é feita em outra cidade. & 3 \\
\hline Bibliotecas onde não foi possível marcar a entrevista & 2 \\
\hline Total de bibliotecas onde foram feitas entrevistas & 10 \\
\hline
\end{tabular}

Fonte: Autoria própria.

\subsubsection{Pré-teste}

Faziam parte do universo da pesquisa as bibliotecas que haviam comprado ou que pretendiam comprar livros eletrônicos. Depois de identificado o universo da pesquisa foi possível prosseguir para a fase seguinte, que são entrevistas feitas pessoalmente seguindo um formulário. Para o pré-teste foram realizadas entrevistas seguindo um formulário em quatro instituições com perfis e tamanhos diferentes. O quadro 8 a seguir apresenta alguns dados das bibliotecas onde foram feitas entrevistas.

Quadro 8 - Tamanho das bibliotecas.

\begin{tabular}{|c|c|c|c|c|}
\hline Biblioteca & $\mathbf{A}$ & B & $\mathbf{C}$ & D \\
\hline Tipo & Especializada & Universitária & Especializada & Especializada \\
\hline Funcionários & 4 & 250 & 8 & 50 \\
\hline Bibliotecários & 1 & 42 & 4 & 28 \\
\hline Acervo & 5 mil itens. & $\begin{array}{l}\text { 1,5 milhão de } \\
\text { itens. }\end{array}$ & $\begin{array}{lr}15 \text { mil livros e } \\
\text { de } 300 \text { a } 350 \\
\text { títulos } & \text { de } \\
\text { periódicos. }\end{array}$ & $\begin{array}{l}163 \text { mil e } 653 \\
\text { itens. }\end{array}$ \\
\hline $\begin{array}{ll}\text { Sistema } & \text { de } \\
\text { automação } & \\
\end{array}$ & Sophia & Pergamum & EOS & Aleph e DSpace \\
\hline Tem OPAC? & Sim. & Sim. & Sim. & Sim. \\
\hline Orçamento & Não informado. & $\begin{array}{l}1 \text { milhão de } \\
\text { reais } \\
\text { material } \\
\text { impresso. }\end{array}$ & $\begin{array}{l}\text { Não tem } \\
\text { orçamento fixo. }\end{array}$ & 897 mil reais. \\
\hline
\end{tabular}

Fonte: Autoria própria.

Essa variedade nos locais onde o pré-teste foi realizado se repetiu em outras instituições onde foi feita coleta de dados, já que não existe um único perfil para as bibliotecas que compram livros eletrônicos. A realização de entrevistas em locais diferentes também foi importante para 
a adequação do formulário às necessidades da pesquisa. A evolução do formulário pode ser observada na seção seguinte.

Durante o pré-teste também foi realizada uma entrevista sem formulário com a bibliotecária do setor de aquisição da $\mathrm{BCE} / \mathrm{UnB}$ responsável por estudar as ofertas dos vendedores. Essa entrevista foi realizada devido ao notório saber da funcionária sobre o assunto da dissertação e foi muito importante para a obtenção de informações e para a solução de dúvidas. Nessa entrevista não foi utilizado o formulário pois a bibliotecária não possuía informações sobre compras anteriores da biblioteca, já que sua atribuição era conhecer as ofertas dos vendedores para a realização de uma nova compra. Foram obtidas informações sobre vendedores do mercado brasileiro que possuem foco em bibliotecas universitárias e sobre seus modelos de negócios.

A partir das entrevistas já realizadas foi possível observar que a realidade da aquisição de livros eletrônicos no Brasil corresponde ao o que é dito na literatura mundial. Também foi observada a necessidade de disponibilização de mais informações organizadas sobre o assunto a fim de facilitar o trabalho e o aprendizado dos bibliotecários. Os bibliotecários entrevistados se mostraram dispostos e contentes em poderem contribuir com a pesquisa sobre o assunto. Foi possível observar sua preocupação com diferentes aspectos da aquisição de livros eletrônicos para bibliotecas, como a falta de ofertas para instituições menores e o efeito a longo prazo da aquisição de materiais apenas em formato eletrônico para a preservação do conhecimento de uma área.

\subsection{FORMULÁRIO DA ENTREVISTA}

Na primeira instituição a entrevista foi feita com base em um extenso formulário com 83 questões. Esse primeiro formulário era muito abrangente, abordando todo o ciclo do livro eletrônico dentro da biblioteca e indo além do foco da pesquisa. A primeira versão do formulário pode ser vista no apêndice B. Logo esse formulário foi reformulado e reduzido para 66 questões. A segunda versão do formulário foi utilizada para as entrevistas nas três bibliotecas seguintes e pode ser vista no Apêndice C. As questões da segunda versão abordam o conteúdo da pesquisa divididas de acordo com o que aparece no Quadro 9: 
Quadro 9 - Organização do formulário de entrevista.

\begin{tabular}{|c|c|c|c|c|c|c|c|}
\hline $\begin{array}{c}\mathrm{N}^{\mathbf{o}} \text { das } \\
\text { perguntas }\end{array}$ & $\begin{array}{l}\text { Dados da } \\
\text { biblioteca }\end{array}$ & Vendedores & $\begin{array}{c}\text { Modelos } \\
\text { de } \\
\text { negócios }\end{array}$ & $\begin{array}{l}\text { Modelos } \\
\text { de seleção }\end{array}$ & $\begin{array}{c}\text { Meio de } \\
\text { acesso e } \\
\text { uso }\end{array}$ & $\begin{array}{c}\text { Modelos } \\
\text { de acesso } \\
\text { dos } \\
\text { usuários }\end{array}$ & $\begin{array}{l}\text { Licença } \\
\text { de venda }\end{array}$ \\
\hline 1 a 9 & & & & & & & \\
\hline 10 a 24 & & & & & & & \\
\hline 25 a 28 & & & & & & & \\
\hline 29 a 37 & & & & & & & \\
\hline 38 a 52 & & & & & & & \\
\hline 53 a 55 & & & & & & & \\
\hline 56 a 66 & & & & & & & \\
\hline
\end{tabular}

Fonte: Autoria própria.

O formulário da entrevista foi elaborado com base na revisão de literatura, buscando levantar dados sobre os mesmos tópicos mencionados pelos autores, permitindo assim uma comparação da realidade com os textos.

O formulário da entrevista também utilizou perguntas elaboradas por Doucette e Lewontin (2012, p. 71), Vasileiou, Rowley e Hartley (2012, Apêndice A) e Barros (2014, Módulo 3, Aula 2). As perguntas dos autores citados aparecem em seus textos como sugestões de questionamentos que as bibliotecas devem fazer no momento de decisão sobre a compra de livros eletrônicos.

As perguntas foram divididas em blocos que correspondem à divisão da revisão de literatura.

O primeiro bloco vai da pergunta 1 a 9, e busca levantar dados da biblioteca para que seja possível traçar seu perfil e definir o seu tamanho sem identificar a instituição.

A pergunta 1 é o nome da biblioteca, para permitir sua identificação pelo pesquisador, sem que essa informação seja necessariamente incluída na pesquisa por questões de identificação do respondente.

A pergunta 2 identifica o órgão ao qual a biblioteca está vinculada, já que muitas surgem por uma necessidade informacional da instituição.

A pergunta 3 identifica o número de funcionários, para melhor determinar o tamanho da biblioteca.

A pergunta 4 verifica quantos desses funcionários são bibliotecários.

A pergunta 5 identifica o tipo de biblioteca, determinando assim qual é o foco da sua coleção.

A pergunta 6 busca saber o tamanho aproximado do acervo, o que ajuda a determinar o tamanho da biblioteca. 
A pergunta 7 identifica qual é o sistema de automação utilizado pela biblioteca.

A pergunta 8 verifica se a biblioteca possui um catálogo online.

A pergunta 9 busca saber qual é o orçamento anual disponível para a biblioteca, e junto com as perguntas 3, 4 e 6, ajuda a determinar melhor o tamanho da biblioteca sem identificar diretamente de qual instituição se trata. Essa pergunta provavelmente não foi respondida por todas as instituições, mas quando esse dado é fornecido contribui muito para a pesquisa.

O segundo bloco compreende as perguntas de 10 a 24 e busca entender por que a biblioteca decidiu comprar livros eletrônicos, se esse material está previsto em sua política, busca identificar como a biblioteca encontrou os vendedores, quem são os vendedores, por que foram escolhidos, o que eles oferecem, as dificuldades para encontrar material que a biblioteca necessita, e como é o apoio do vendedor depois da compra.

A pergunta 10 busca saber se a política de desenvolvimento de coleções da biblioteca, caso ela exista, já prevê claramente a compra de livros eletrônicos ou de qualquer material digital.

A pergunta 11 busca saber qual é o entendimento do entrevistado sobre as diferenças na compra de livros impressos e eletrônicos.

A pergunta 12 identifica de onde surgiu o interesse da biblioteca pelos livros eletrônicos.

A pergunta 13 procura saber como foi o processo de escolha do vendedor.

A pergunta 14 identifica qual foi o vendedor escolhido pela biblioteca.

A pergunta 15 busca saber se o vendedor de livros eletrônicos é o mesmo que já vendia livros impressos para a biblioteca.

A pergunta 16 busca identificar qual foi o tipo de vendedor escolhido. Além disso, sua resposta permite avaliar o nível de conhecimento do entrevistado sobre o fornecedor dos livros e sobre o mercado de livros eletrônicos.

A pergunta 17 busca identificar quais foram os critérios decisivos para a escolha do fornecedor.

A pergunta 18 avalia se houve um período de teste antes de aquisição para melhor conhecimento do produto.

A pergunta 19 quais são os formatos dos arquivos que contém os livros eletrônicos disponíveis para compra.

A pergunta 20 busca saber se a biblioteca já teve algum problema com livros eletrônicos que não estão disponíveis para compra por bibliotecas.

A pergunta 21 busca saber se o vendedor oferece suporte local em português, já que a língua pode ser uma barreira importante para o diálogo entre a biblioteca e o vendedor. 
A pergunta 22 investiga se existe treinamento para funcionários e usuários. $\mathrm{O}$ treinamento é fundamental para o uso pleno de todas as funcionalidades da plataforma adquirida.

A pergunta 23 busca identificar se o vendedor envia material de treinamento para a biblioteca, e se esse material está em português.

A pergunta 24 busca saber se a biblioteca pode obter estatísticas de uso dos livros, já que a plataforma não é controlada e administrada pela biblioteca. Essas estatísticas são fundamentais para controle de uso do material comprado, para que a biblioteca possa avaliar se a compra valeu a pena e se a assinatura deve ser mantida.

O terceiro bloco de perguntas, que vai da 25 a 28, trata dos modelos de negócios, buscando identificar o modelo escolhido pela biblioteca, as possibilidades do modelo e a razão da sua escolha.

A pergunta 25 busca saber quais são os modelos de negócios praticados pelo vendedor. Ao fazer essa pergunta ao comprador, e não ao vendedor, busca-se identificar quanto o entrevistado conhece sobre os modelos de negócios.

A pergunta 26 busca saber qual foi o modelo escolhido e razão da sua escolha. Assim é possível conhecer como ocorreu a tomada de decisão na compra.

A pergunta 27 busca identificar uma característica específica da assinatura de pacotes, que é a troca de títulos, que quando disponível garante um melhor uso dos recursos da biblioteca.

A pergunta 28 busca saber se existe um limite de número de acessos por título.

O quarto bloco, com as perguntas 29 a 37, procura saber mais sobre os modelos de seleção: qual foi o escolhido, porque foi escolhido e como será a feita a decisão pela renovação ou cancelamento dos títulos.

A pergunta 29 identifica qual foi o modelo escolhido para a seleção dos livros.

A pergunta 30 busca saber por que esse foi o modelo escolhido, analisando assim como foi feita a decisão da biblioteca.

A pergunta 31 busca saber se há desconto para a compra de pacotes, o que ressalta a preferência do vendedor por essa compra.

A pergunta 32 também é relacionada à compra por pacotes, e busca saber qual foi o poder de decisão oferecido para a biblioteca, já que a escolha dos títulos do pacote também é um fator que demonstra maior poder da biblioteca sobre o que é comprado. 
A pergunta 33, ainda sobre pacotes, os vê por outro lado, analisando se os títulos não desejados pela biblioteca, que mesmo com a escolha e a troca acabaram sendo incluídos no pacote, compensaram o gasto total com o pacote.

A pergunta 34 busca saber qual é o acordo para atualização das edições dos livros comprados.

A pergunta 35 busca saber se mesmo com as atualizações é possível acessar edições anteriores. $\mathrm{O}$ acesso às edições recentes é uma vantagem, mas alguns usuários podem necessitar o acesso a edições antigas do mesmo livro.

A pergunta 36 busca saber se existe um período de embargo, no qual o livro já se encontra disponível para compra por outras pessoas, mas não pela biblioteca.

A pergunta 37 busca saber quais são os critérios utilizados para decidir sobre a renovação ou o cancelamento em caso de assinatura dos livros.

O quinto bloco é formado pelas perguntas 38 a 52 e busca saber como o acesso ao material comprado é oferecido aos usuários: qual é a plataforma utilizada, se é necessário o uso de um software, quem tem acesso ao material, se o acesso é online ou por download, qual o prazo de empréstimo, em quais dispositivos o material pode ser acessado e quais são as funcionalidades da plataforma.

A pergunta 38 busca saber se a plataforma de acesso aos livros é própria da biblioteca ou se foi contratada do vendedor.

A pergunta 39 busca saber se é necessário pagar uma taxa de acesso à plataforma do vendedor, o que seria mais um item a ser pesado e incluído no orçamento da compra.

A pergunta 40 busca saber se existe e qual o software usado para acessar os livros.

A pergunta 41 busca saber para quem os livros adquiridos estão disponíveis. Essa pergunta foi feita porque o acesso aos livros costuma ser controlado, já que o número de possíveis usuários pode influenciar no preço dos livros.

A pergunta 42 busca saber como é o acesso, se é online ou por download. Essa pergunta também permite observar o nível de conhecimento do entrevistado sobre a plataforma tecnológica.

A pergunta 43 questiona se é possível ler os livros off-line, confirmando a informação dada na questão anterior.

A pergunta 44 busca saber qual é o período de empréstimo estipulado pela biblioteca, e se é possível renovar.

A pergunta 45 busca saber como se dá o acesso aos livros dentro da biblioteca.

A pergunta 46 busca saber como é o acesso aos livros fora da biblioteca. 
A pergunta 47 busca saber com quais dispositivos os livros comprados são compatíveis. Essa pergunta também avalia o nível de conhecimento do entrevistado sobre a tecnologia utilizada.

A pergunta 48 busca saber se a interface de acesso aos livros está em português, o que facilitaria o acesso dos usuários ao material.

A pergunta 49 identifica se existe a possibilidade de fazer buscas no texto completo, o que é uma qualidade inerente ao livro eletrônico que proporciona uma grande vantagem no seu uso.

A pergunta 50 identifica se a plataforma oferece algumas funcionalidades básicas, presentes na maioria dos softwares utilizados para leitura de livros eletrônicos.

A pergunta 51 busca saber se é possível copiar e imprimir conteúdo, que são restrições que o direito autoral impõe ao material eletrônico.

A pergunta 52 busca saber da integração dos livros eletrônicos com o resto do acervo da biblioteca. Essa integração facilita a descoberta do material eletrônico como parte integrante do acervo.

O sexto bloco com as perguntas 53 a 55 busca saber qual é o modelo de acesso dos usuários, quantas pessoas podem ler o mesmo livro ou utilizar a plataforma ao mesmo tempo e o porquê da escolha de determinado modelo.

A pergunta 53 busca saber qual foi o modelo de acesso adquirido pela biblioteca.

A pergunta 54 investiga o motivo pelo qual esse foi o modelo escolhido.

A pergunta 55 busca saber se há um limite máximo de acessos simultâneos à plataforma, o que restringiria o acesso a um número determinado de pessoas. Isso pode ser preocupante em grandes bibliotecas que possuem um elevado número de acessos, além de negar o acesso quando ele é mais necessário.

O último bloco de perguntas é o sétimo (56 a 66) e busca informações sobre a licença de venda, o que está ou não claramente determinado por ela e quais são os direitos e deveres da biblioteca e do vendedor.

A pergunta 56 busca saber quem é o responsável pela negociação com os vendedores. A negociação é um processo multidisciplinar que exige conhecimentos sobre a biblioteca e o produto a ser comprado, além de noções de direito relativas ao contrato e de informática para compreender o material eletrônico. A partir dessa resposta será possível perceber a qual profissional tem sido atribuída essa tarefa.

A pergunta 57 busca saber se a licença esclarece as formas de acesso e uso do material. 
A pergunta 58 busca saber se a licença esclarece quem são as pessoas autorizadas a acessar o conteúdo.

A pergunta 59 busca saber se as restrições relativas aos livros constam na licença.

A pergunta 60 busca saber quais serviços estão incluídos no contrato.

A pergunta 61 busca saber quais direitos da biblioteca constam no contrato.

A pergunta 62 busca saber se a biblioteca está protegida legalmente caso os usuários façam uso não autorizado do material.

A pergunta 63 busca saber quem é o responsável pelo armazenamento e preservação dos arquivos eletrônicos dos livros.

A pergunta 64 busca saber se a biblioteca possui garantia de acesso aos livros de uma editora se essa editora sair da plataforma.

A pergunta 65 busca saber se a biblioteca possui a garantia de receber os arquivos dos livros comprados caso a plataforma encerre seus negócios.

A pergunta 66 busca saber quais foram as principais dificuldades legais para a compra dos livros eletrônicos.

\subsection{PLANEJAMENTO DA ANÁLISE DE DADOS}

A análise de dados foi feita qualitativamente, comparando as respostas das bibliotecas entre si e com a literatura. Todas as entrevistas foram gravadas e transcritas, o que permitiu a sua análise. A partir das respostas das bibliotecas foi possível identificar quais modelos de negócios são utilizados pelas bibliotecas do DF e quais são as dificuldades enfrentadas pelas bibliotecas no processo de compra e negociação. 


\section{ANÁLISE DE DADOS}

$\mathrm{Na}$ análise de dados cada biblioteca será identificada por uma letra do alfabeto seguindo a ordem cronológica na qual as entrevistas foram realizadas. Será utilizada a recomendação de Cresswell (2010), citada anteriormente na metodologia, de dissociar os indivíduos de suas respostas para proteger o anonimato. Cada pergunta do formulário será identificada por seu número correspondente; a lista das bibliotecas participantes da coleta de dados consta no Apêndice E.

$\mathrm{Na}$ biblioteca $\mathrm{A}$ foi feita uma entrevista com a primeira versão do formulário, que consta no Apêndice B. Muitas perguntas, tanto do formulário de entrevista antigo quanto do novo, não se enquadram na realidade dessa biblioteca e por isso serão identificadas com a expressão "não se aplica". Como a maioria das perguntas dos dois formulários eram as mesmas e estavam apenas em uma ordem diferente, não foi necessário fazer uma nova entrevista nessa biblioteca. A segunda versão do formulário de entrevista está no Apêndice C.

A biblioteca A comprou um aparelho leitor de livros eletrônicos da marca Kobo e apenas, a partir disso, começou a comprar os livros. Então, para essa biblioteca o ponto de partida foi o aparelho e não os livros. Além disso, por essa ser uma biblioteca pequena, ela não possui recursos para adquirir uma plataforma, e essa foi a solução encontrada para oferecer livros eletrônicos aos usuários.

O formulário foi dividido em blocos agrupados de acordo com o assunto das perguntas. O primeiro bloco vai da pergunta 1 à 9 , e apresenta dados que permitem identificar o perfil de cada biblioteca. No quadro 10 é possível observar dados de cada uma das dez bibliotecas onde foram feitas entrevistas. Esse quadro inclui: tipo de biblioteca, número de funcionários, quantidade de bibliotecários, tamanho do acervo, quantidade de livros eletrônicos, sistema de automação, existência de OPAC e orçamento. Esses dados permitem verificar o perfil de cada biblioteca, o seu tamanho e outras informações que influenciam todas as respostas seguintes. 
Quadro 10 - Dados das bibliotecas

\begin{tabular}{|c|c|c|c|c|c|c|c|c|c|c|}
\hline $\begin{array}{l}\text { Bibliotec } \\
\text { a }\end{array}$ & $\mathbf{A}$ & B & $\mathrm{C}$ & D & $\mathbf{E}$ & $\mathbf{F}$ & $\mathbf{G}$ & $\mathbf{H}$ & I & $\mathbf{J}$ \\
\hline 5. Tipo & $\begin{array}{l}\text { Especia- } \\
\text { lizada }\end{array}$ & $\begin{array}{l}\text { Universit } \\
\text { á-ria }\end{array}$ & $\begin{array}{l}\text { Especia- } \\
\text { lizada }\end{array}$ & $\begin{array}{l}\text { Especia- } \\
\text { lizada }\end{array}$ & $\begin{array}{l}\text { Especia- } \\
\text { lizada }\end{array}$ & $\begin{array}{l}\text { Universit } \\
\text { á-ria }\end{array}$ & $\begin{array}{l}\text { Especia- } \\
\text { lizada }\end{array}$ & $\begin{array}{l}\text { Especia- } \\
\text { lizada }\end{array}$ & $\begin{array}{l}\text { Especia- } \\
\text { lizada }\end{array}$ & $\begin{array}{l}\text { Universit } \\
\text { á-ria }\end{array}$ \\
\hline $\begin{array}{l}\text { 3.Funcio } \\
\text { nários }\end{array}$ & 4 & 250 & 8 & 50 & 8 & 40 & 12 & 11 & $\begin{array}{l}\text { Mais de } \\
20\end{array}$ & 7 \\
\hline $\begin{array}{l}\text { 4.Bibliot } \\
\text { ecários }\end{array}$ & 1 & 42 & 4 & 28 & 4 & 9 & 3 & 4 & & 1 \\
\hline $\begin{array}{l}6 . \\
\text { Acervo }\end{array}$ & $\begin{array}{ll}5 & \text { mil } \\
\text { itens } & \end{array}$ & $\begin{array}{l}1,5 \\
\text { milhão } \\
\text { de itens }\end{array}$ & $\begin{array}{l}15 \text { mil } \\
\text { livros e } \\
\text { de } 300 \text { a } \\
350 \\
\text { títulos de } \\
\text { periódico } \\
\text { s }\end{array}$ & $\begin{array}{l}163.653 \\
\text { itens }\end{array}$ & $\begin{array}{l}49 \text { mil } \\
\text { itens } \\
\text { (impress } \\
\text { o e } \\
\text { digital, e } \\
\text { periódico } \\
\text { s) }\end{array}$ & $\begin{array}{l}240 \mathrm{mil} \\
\text { livros }\end{array}$ & $\begin{array}{l}20 \text { mil } \\
\text { títulos }\end{array}$ & $\begin{array}{l}\text { Geral: } 13 \\
\text { mil } \\
\text { títulos e } \\
25 \text { mil } \\
\text { exemplar } \\
\text { es. }\end{array}$ & $\begin{array}{l}\text { Livros: } \\
45.932\end{array}$ & $\begin{array}{l}120 \text { mil } \\
\text { exemplar } \\
\text { es }\end{array}$ \\
\hline $\begin{array}{l}\text { Acervo } \\
\text { (apenas } \\
\text { livros } \\
\text { eletrônic } \\
\text { os) }\end{array}$ & 12 livros & $\begin{array}{l}\text { Mais de } \\
70 \text { mil } \\
\text { (entrevist } \\
\text { a. No site } \\
\text { diz que } \\
\text { são mais } \\
\text { de } \\
\text { 199.046 } \\
\text { livros) }\end{array}$ & $\begin{array}{l}\text { Não é } \\
\text { possível } \\
\text { dizer } \\
\text { exatame } \\
\text { nte o } \\
\text { tamanho } \\
\text { do } \\
\text { acervo } \\
\text { porque a } \\
\text { compra é } \\
\text { feita por } \\
\text { pacotes. }\end{array}$ & 46 livros & $\begin{array}{l}4.994 \\
\text { (Acesso } \\
\text { perpétuo } \\
\text { ) }\end{array}$ & $\begin{array}{l}4.605 \\
\text { ebooks }\end{array}$ & $\begin{array}{l}\text { Menos } \\
\text { de } 10\end{array}$ & $\begin{array}{l}\text { Ebooks: } \\
17.550 \\
\text { títulos. } \\
\text { Ebrary: } \\
13 \text { mil; } \\
\text { Safari } \\
\text { books: } \\
4.500 ; \\
\text { Fórum: } \\
50 \text { títulos }\end{array}$ & $\begin{array}{l}\text { Mais ou } \\
\text { menos } 50\end{array}$ & 6.000 \\
\hline $\begin{array}{l}7 . \\
\text { Sistema } \\
\text { de } \\
\text { automaç } \\
\text { ão }\end{array}$ & Sophia & $\begin{array}{l}\text { Pergamu } \\
\mathrm{m}\end{array}$ & EOS & $\begin{array}{l}\text { Aleph e } \\
\text { DSpace }\end{array}$ & Ainfo & $\begin{array}{l}\text { Thesauru } \\
\text { s }\end{array}$ & $\begin{array}{l}\text { Pergamu } \\
\mathrm{m}\end{array}$ & Sophia & Aleph & SCB \\
\hline $\begin{array}{l}\text { 8. Tem } \\
\text { OPAC? }\end{array}$ & Sim. & Sim. & Sim. & Sim. & Sim. & Sim. & Sim. & Sim. & Sim. & Sim. \\
\hline $\begin{array}{l}9 . \\
\text { Orçame } \\
\text { nto }\end{array}$ & $\begin{array}{l}\text { Não } \\
\text { informad } \\
\text { o. }\end{array}$ & $\begin{array}{l}1 \text { milhão } \\
\text { de reais } \\
\text { para } \\
\text { material } \\
\text { impresso } \\
\text {. }\end{array}$ & $\begin{array}{l}\text { Não tem } \\
\text { orçament } \\
\text { o fixo. }\end{array}$ & $\begin{array}{l}897 \text { mil } \\
\text { reais. }\end{array}$ & $\begin{array}{l}\text { Não tem } \\
\text { orçament } \\
\text { o fixo. }\end{array}$ & $\begin{array}{l}\text { Não } \\
\text { informad } \\
\text { o. }\end{array}$ & $\begin{array}{l}\text { Total: } \\
\text { R\$1.333. } \\
000 \\
\text { Livros: } \\
\text { R\$ } 80 \\
\text { mil. } \\
\text { Periódic } \\
\text { os: R\$ } \\
40 \text { mil. } \\
\text { Bases: } \\
\text { R\$ } 60 \\
\text { mil. }\end{array}$ & $\begin{array}{l}\text { Não tem } \\
\text { orçament } \\
\text { o fixo. }\end{array}$ & $\begin{array}{l}\text { Não } \\
\text { informad } \\
\text { o. }\end{array}$ & $\begin{array}{l}\text { Mais de } \\
1 \text { milhão } \\
\text { de reais. }\end{array}$ \\
\hline
\end{tabular}

Fonte: Autoria própria.

Foram feitas entrevistas em sete bibliotecas especializadas em áreas diferentes, três delas em Direito. As outras são especializadas em áreas diversas, como Medicina e Agropecuária. Observa-se que as bibliotecas públicas e escolares são os únicos dois tipos de bibliotecas que, à época, não fizeram parte do universo da pesquisa.

De acordo com o número de funcionários, a maior biblioteca é a $\mathrm{B}$ e a menor é a $\mathrm{A}$. A biblioteca $\mathrm{B}$ possui um número de funcionários 62,5 vezes maior, e 41 bibliotecários a mais que a biblioteca A. Enquanto a biblioteca A comprou doze livros eletrônicos, a biblioteca B 
oferece mais de 70 mil. Essa diferença enriquece a pesquisa, que teve a oportunidade de observar a compra de livros eletrônicos em realidades muito distintas.

Os softwares de automação de bibliotecas mais utilizados, que estão cada um em duas bibliotecas, são o Aleph, o Pergamum e o Sophia. Os três são softwares proprietários, o que significa que essas bibliotecas possuem condições de pagar por eles.

Seis bibliotecas não informaram o seu orçamento (A, C, E, F, H e I). As bibliotecas C, E e H não puderam informar um valor pois o orçamento não é fixo e varia de acordo com a necessidade da biblioteca.

Um fato que não estava no formulário, mas que pôde ser observado e que chamou a atenção foi que seis bibliotecas (B, C, E, F, I e J) disponibilizavam os livros eletrônicos para outras bibliotecas da rede. Essas bibliotecas se distribuem por espaços físicos distintos e por isso viram nos livros eletrônicos uma vantagem adicional. Com o uso de livros eletrônicos elas não precisam mais comprar um exemplar para cada unidade da biblioteca.

O segundo bloco de perguntas vai da 10 à 24, e trata do vendedor e do suporte técnico. A pergunta “10. A política de desenvolvimento de coleções da biblioteca inclui livros eletrônicos ou outros recursos digitais?" busca saber se a política de desenvolvimento de coleções da biblioteca inclui os documentos eletrônicos.

Entre o universo de dez bibliotecas pesquisado, nove possuem uma política de desenvolvimento de coleções (todas menos a biblioteca $\mathrm{C}$ ), mas apenas um terço dessas políticas incluem os documentos eletrônicos (bibliotecas D, F e J). Isso corresponde ao que acontece com o estágio atual da literatura brasileira de desenvolvimento de coleções, que ainda não está preparada para os materiais eletrônicos. Os critérios utilizados na seleção de livros eletrônicos são os mesmos utilizados na seleção dos impressos. A seleção também é tratada nas questões 17 e 29.

A decisão de comprar materiais eletrônicos antes mesmo que eles estejam previstos na política de seleção reflete a necessidade imediatista dos usuários, já tendo sido mencionada por Gregory (2011).

A biblioteca $C$ não possui uma política escrita pois esse é o perfil da instituição da qual ela faz parte, que prioriza não perder tempo com o meio. "Como a instituição é pequena é fácil controlar o que deve ou não ser comprado, e se uma nova área deve ser inserida no acervo" (BIBLIOTECA C).

A questão do quadro 11 é intencionalmente ampla, para avaliar a percepção geral dos entrevistados sobre a compra. Além disso, assim como as questões anteriores, serve como introdução ao tema, que vai sendo aprofundado e ficando cada vez mais técnico com o 
desenrolar da entrevista. Cada biblioteca destaca uma questão diferente, mas todas elas são importantes.

Quadro 11 - Diferenças entre a compra de livros impressos e eletrônicos

\section{Quais são as principais diferenças entre a compra de livros impressos e} eletrônicos?

A A falta de oferta de um modelo específico para bibliotecas com empréstimo, reserva e prazo para devolução. E a falta de informações sobre o assunto.

B Os livros impressos são comprados de acordo com as indicações de professores e alunos. "O processo de compra de livros eletrônicos é diferente. As editoras entram em contato com os bibliotecários e apresentam a base, que é colocada à disposição da comunidade universitária para avaliação. Depois da avaliação, se o número de acessos tiver sido bom e houver dotação orçamentária é feita a aquisição. "

C "O que mais me incomoda na política de livro eletrônico é a impossibilidade de escolha". A biblioteca não pode selecionar por título, é obrigada a comprar o pacote.

D "A nossa negociação passa a ser direto com a editora e não mais com o fornecedor".

E O impresso é selecionado por título e o eletrônico por pacote, de acordo com as áreas de interesse.

F $\quad$ A diferença está no tempo que demora para o usuário final ter acesso ao livro. "O principal motivo para a aquisição de livros eletrônicos é o acesso rápido para o usuário final".

G Assinatura (continuidade de acesso).

H $\quad$ Disponibilidade (livros importados).

I Modelos novos e diferentes.

J Facilidade. Vantagens: é mais fácil comprar livros eletrônicos, eles não esgotam. Desvantagens: Se a Internet cair ou der um problema no servidor, não tem mais acesso ao livro eletrônico. É preciso verificar constantemente se as bases estão funcionando. Se não renovar o contrato o ebook some. As pessoas ainda não têm o hábito de ler o livro eletrônico, então é necessário divulgar bastante.

Fonte: Autoria própria.

A biblioteca A teve muita dificuldade para encontrar a oferta de um modelo específico de venda de livros eletrônicos para bibliotecas que fosse similar ao OverDrive, com empréstimo, reserva e devolução automática com prazo. O entrevistado buscou informações com especialistas, professores e grupos de discussão e "ninguém sabia dizer o que estava acontecendo na época no Brasil em relação às bibliotecas”.

A biblioteca B destaca a inversão que acontece no processo de compra. Antes, os compradores buscavam os vendedores, mas na venda de livros eletrônicos o movimento contrário parece ser maior. As empresas oferecem seus produtos novos para as bibliotecas e disponibilizam períodos de teste. Mas o interesse parte do vendedor, que agora busca uma boa base de clientes, principalmente os mais importantes e com mais visibilidade, para ganhar credibilidade e então conquistar outros. 
Muitas editoras já são reconhecidas no mercado de livros impressos e isso é levado em conta pelos bibliotecários da aquisição. Mas, mesmo que o conteúdo da base de uma editora seja bom, se a sua plataforma de acesso não for estável, com bom funcionamento, o cliente pode desistir da compra. A biblioteca $\mathbf{J}$ relatou ter desistido por duas vezes de comprar do mesmo fornecedor (cujo nome não foi citado) porque a sua plataforma tinha muitos problemas e passava muito tempo indisponível. Isso se reflete na resposta dessa biblioteca para a pergunta 11, que diz que é importante verificar constantemente o funcionamento da base.

As bibliotecas C e E decidiram destacar os entraves colocados pelos vendedores, que oferecem apenas a seleção por pacotes, e não disponibilizam a opção de escolha apenas dos títulos desejados. Esse problema será discutido mais a fundo nas questões 29 e 30.

A biblioteca $\mathrm{D}$ destaca o fato de que a venda muitas vezes é realizada de forma exclusiva pela editora, e por isso a biblioteca negocia diretamente com a fonte, sem intermediários. Isso pode garantir maiores descontos e exigências diferenciadas, como o pedido da posse dos arquivos dos livros adquiridos. Roncevic (2013) diz que as editoras são mais abertas a negociações que os fornecedores, e foi possível observar isso nessa pesquisa.

A biblioteca $\mathrm{F}$ destacou uma vantagem dos livros eletrônicos, que é a rapidez na entrega do material comprado. Os livros importados podem demorar meses para serem entregues, e mesmo no Brasil os grandes estoques ficam em São Paulo, como foi citado na entrevista F. Para os livros eletrônicos, basta efetuar o pagamento e ele já estará disponível para o usuário final, economizando também o tempo necessário para o processamento técnico, como também foi mencionado na entrevista $\mathrm{H}$.

Para a biblioteca $\mathrm{G}$ a principal diferença está na continuidade do acesso, na garantia de acessar o material pago no caso de assinaturas. Em tempos de cortes de recursos para as bibliotecas é muito arriscado apenas assinar um material que irá desaparecer caso a biblioteca não possua recursos para fazer a renovação.

Para a biblioteca I a principal diferença na compra de livros eletrônicos está nos modelos de negócios: "Cada editora trabalha com um modelo diferente, principalmente as nacionais, que são diferentes entre si e das estrangeiras. Além disso, os vendedores não cumprem o que prometem e falta qualidade nos produtos oferecidos" (BIBLIOTECA I).

A biblioteca $\mathrm{J}$ destacou a facilidade como a principal característica da compra de livros eletrônicos, mas sem esquecer das suas desvantagens, e terminou a sua observação com uma crítica: "Quando o novo é bom e melhor, a transição é mais fácil. Esse formato online é pouco maleável, dificultando o uso" (BIBLIOTECA J). 
As diferenças na compra de livros impressos e eletrônicos foram mencionadas no quadro 1, do tópico 2.6. Nesse quadro estão presentes apenas os aspectos mencionados pelas bibliotecas F e H. O quadro 12 faz a comparação dos aspectos mencionados pelas outras bibliotecas com algumas observações, pois a realidade de uma biblioteca nem sempre se aplica a todas.

Quadro 12 - Diferenças na compra de livros impressos e eletrônicos II

\begin{tabular}{|c|c|c|c|}
\hline \multicolumn{4}{|c|}{ 11. Quais são as principais diferenças entre a compra de livros impressos e eletrônicos? } \\
\hline $\begin{array}{c}\text { Biblio- } \\
\text { teca }\end{array}$ & IMPRESSO & ELETRÔNICO & COMENTÁRIOS \\
\hline A & $\begin{array}{l}\text { A biblioteca compra o livro e } \\
\text { decide como será o } \\
\text { empréstimo. }\end{array}$ & $\begin{array}{l}\text { Faltam modelos específicos para } \\
\text { bibliotecas. }\end{array}$ & $\begin{array}{l}\text { Quando decidiu comprar livros } \\
\text { eletrônicos essa biblioteca não } \\
\text { encontrou informações sobre o } \\
\text { assunto e nem outras bibliotecas } \\
\text { que já comprassem. }\end{array}$ \\
\hline B & $\begin{array}{l}\text { As indicações para compra } \\
\text { são feitas pelos professores e } \\
\text { alunos. }\end{array}$ & $\begin{array}{l}\text { As editoras entram em contato } \\
\text { com a biblioteca e oferecem um } \\
\text { período de teste para a base. Ela } \\
\text { é avaliada e depois é decidido se } \\
\text { a compra será feita. }\end{array}$ & \\
\hline $\mathrm{CeE}$ & $\begin{array}{l}\text { Os livros são selecionados } \\
\text { por título. }\end{array}$ & $\begin{array}{l}\text { As bibliotecas são obrigadas a } \\
\text { fazer a seleção por pacote. }\end{array}$ & $\begin{array}{l}\text { Os livros eletrônicos também } \\
\text { podem ser selecionados por } \\
\text { título, mas apenas quando o } \\
\text { vendedor oferece essa opção. }\end{array}$ \\
\hline $\mathrm{D}$ & $\begin{array}{l}\text { As negociações são feitas } \\
\text { com o fornecedor. }\end{array}$ & $\begin{array}{l}\text { A negociação é feita diretamente } \\
\text { com a editora, sem um } \\
\text { intermediário. }\end{array}$ & $\begin{array}{l}\text { A compra também pode ser feita } \\
\text { com distribuidores } \\
\text { agregadores, que } \\
\text { intermediários. }\end{array}$ \\
\hline G & $\begin{array}{l}\text { O material comprado fica } \\
\text { para sempre com a } \\
\text { biblioteca. }\end{array}$ & $\begin{array}{l}\text { Quando a biblioteca não tem } \\
\text { condições de renovar a } \\
\text { assinatura, perde o acesso ao } \\
\text { material. }\end{array}$ & $\begin{array}{l}\text { Algumas bibliotecas já } \\
\text { conseguem ter acesso ao período } \\
\text { que foi pago, mesmo que não } \\
\text { possam renovar. }\end{array}$ \\
\hline I & $\begin{array}{l}\text { A compra é igual com } \\
\text { qualquer vendedor. }\end{array}$ & $\begin{array}{l}\text { Os modelos são diferentes para } \\
\text { cada editora. }\end{array}$ & $\begin{array}{l}\text { A variedade de modelos } \\
\text { confunde bibliotecários e } \\
\text { usuários. }\end{array}$ \\
\hline $\mathbf{J}$ & Os exemplares se esgotam. & $\begin{array}{l}\text { Os exemplares não se esgotam, } \\
\text { sempre é possível comprar. }\end{array}$ & \\
\hline $\mathbf{J}$ & $\begin{array}{l}\text { O livro não depende de } \\
\text { Internet. }\end{array}$ & $\begin{array}{l}\text { Quando a Internet cai, não tem } \\
\text { mais acesso ao livro. }\end{array}$ & \\
\hline
\end{tabular}

Fonte: Autoria própria.

O quadro 12 complementa as informações do quadro 1. A compra de livros eletrônicos envolve muitos aspectos que podem ser analisados sob inúmeros ângulos diferentes. A opinião dos entrevistados complementa os aspectos mencionados na revisão de literatura.

A questão "12. Por que a biblioteca decidiu comprar livros eletrônicos?”, do quadro 13, busca identificar o motivo que levou à busca por esse novo formato, além das principais vantagens dos livros eletrônicos. 
Quadro 13 - Motivo para a compra de livros eletrônicos

\begin{tabular}{|l|l|}
\hline \multicolumn{2}{|l|}{ 12. Por que a biblioteca decidiu comprar livros eletrônicos? } \\
\hline A & $\begin{array}{l}\text { "Esse é um diferencial que essa biblioteca queria proporcionar para o usuário, de } \\
\text { trazer uma novidade para o público e dizer: pra [sic]você que não gosta de ler no } \\
\text { computador, essa leitura é diferente". }\end{array}$ \\
\hline B & $\begin{array}{l}\text { Facilidade de acesso para as outras unidades, o número de acessos simultâneos, a } \\
\text { economia de espaço. }\end{array}$ \\
\hline C & $\begin{array}{l}\text { Para atender às várias unidades espalhadas pelo Brasil. Quando existia apenas o } \\
\text { livro impresso, várias obras eram duplicadas para as unidades, ou o capítulo era } \\
\text { escaneado ou o livro era enviado por malote. }\end{array}$ \\
\hline D & $\begin{array}{l}\text { Economia, pois não precisa comprar vários exemplares; diminui o gasto com } \\
\text { fotocópias; reduz o impacto ambiental pois deixa de usar papel e produzir resíduos. }\end{array}$ \\
\hline E & $\begin{array}{l}\text { Acesso a 47 unidades da rede com uma única compra, reduzindo custos e otimizando } \\
\text { o acesso. }\end{array}$ \\
\hline F & $\begin{array}{l}\text { "Na minha opinião é um caminho que deve ser seguido por causa da tecnologia"... } \\
\text { Como o acesso é simultâneo e ilimitado, existe um exemplar do livro eletrônico para } \\
\text { cada aluno da universidade. }\end{array}$ \\
\hline G & Os usuários pediram. \\
\hline H & Porque existia uma demanda, comprou para atrair os usuários. \\
\hline I & Acesso - unidades espalhadas. \\
\hline J & $\begin{array}{l}\text { "O centro de informação em geral tem que acompanhar a evolução das coisas. O livro } \\
\text { eletrônico faz parte da evolução do centro de documentação. E um problema muito } \\
\text { grave que temos é espaço". }\end{array}$ \\
\hline Fon
\end{tabular}

Fonte: Autoria própria.

O item mais citado foi a possibilidade do acesso em rede, que foi mencionado por B, C,

E e I. As vantagens do acesso em rede são descritas pela biblioteca E:

Antes, comprávamos periódicos e livros para mais de uma unidade, alguns periódicos eram comprados para todas as unidades. Hoje, com apenas uma assinatura eletrônica é possível dar acesso para todos. Da mesma forma ocorre com o livro. Então vimos uma oportunidade de reduzir custos e otimizar o acesso (BIBLIOTECA E).

A biblioteca $\mathrm{C}$ destacou que as unidades de Belém e Macapá da instituição da qual ela faz parte foram muito beneficiadas com a compra de livros eletrônicos. Essas unidades são muito pequenas e não possuem espaços para uma biblioteca física, mas agora têm acesso imediato para vários usuários ao mesmo tempo, e Brasília presta o serviço de levantamento bibliográfico a distância.

O segundo item mais citado foi a questão da evolução tecnológica (A, F e J), que precisa ser acompanhada pelas bibliotecas, para que elas possam atender melhor às necessidades de seus usuários, sem ficar para trás no tempo.

Empatados no terceiro lugar tendo sido citados por duas bibliotecas cada um estão a economia de espaço (B e J) e a demanda dos usuários ( $\mathrm{G}$ e H). Muitas bibliotecas que fazem parte de instituições tiveram seus espaços reduzidos, mas mesmo perdendo em espaço físico 
elas podem ganhar em qualidade e quantidade de documentos com um bom acervo eletrônico. Além disso, os livros eletrônicos também são a melhor opção para bibliotecas pequenas, como a biblioteca A, que não tem espaço para crescer e por isso adota a política de crescimento zero, comprando apenas um exemplar por título. A biblioteca $\mathbf{J}$ mencionou a questão do espaço em outro momento da entrevista, e disse que por isso dá preferência ao que é digital, usando os livros eletrônicos para dar mais opções aos alunos além da bibliografia básica.

A demanda dos usuários foi mencionada pelas bibliotecas $\mathrm{G}$ e $\mathrm{H}$, sendo que na primeira a iniciativa partiu dos usuários e na segunda, foi utilizada pela biblioteca para atraí-los. Os livros eletrônicos já fazem parte do dia-a-dia de alguns usuários, e suas vantagens podem atrair aqueles que ainda não o conhecem.

A biblioteca D citou dois fatores diferentes: a economia e a redução do impacto ambiental. A economia é um fator intrínseco às bibliotecas que compraram os livros para serem disponibilizados em rede, atendendo assim a várias unidades com apenas uma compra. E mesmo na biblioteca que não trabalha em rede, dependendo do modelo de acesso, um mesmo livro eletrônico pode atender a um número ilimitado de usuários sem que seja necessário comprar vários exemplares.

A redução do impacto ambiental é outra vantagem dos livros eletrônicos citada pela biblioteca D. Com a compra do eletrônico não existe gasto de papel e consequentemente corte de árvores, e os exemplares impressos podem ser doados para outras bibliotecas com menos recursos, contribuindo também para a sustentabilidade (BIBLIOTECA D). Isso sem falar que os livros eletrônicos não precisam ser transportados (a não ser digitalmente, claro) e por isso não há poluição gerada pela queima de combustível dos meios de transporte como navio e caminhão, que levariam toneladas de papel pelo mundo. Os livros eletrônicos são sustentáveis e promovem a eficiência econômica, a prudência ecológica e a justiça social (BIBLIOTECA D).

A questão 13 indagou "Como foi feita a escolha do vendedor/fornecedor", para obter mais informações sobre o processo de escolha do vendedor. As respostas das bibliotecas constam do quadro 14. 
Quadro 14 - Escolha do vendedor/fornecedor

\begin{tabular}{|l|l|}
\hline 13. Como foi feita a escolha do vendedor/fornecedor? \\
\hline A & $\begin{array}{l}\text { A biblioteca deu preferência para a compra de um aparelho vendido e com suporte no Brasil. } \\
\text { "Foi o único vendedor que foi encontrado no Brasil. O que tira a burocracia do processo. O } \\
\text { aparelho já vem com a rede, é só colocar o login e senha e comprar os livros. A parte de } \\
\text { compras da empresa faz a compra. A biblioteca fez o teste da Proquest, mas o conteúdo não } \\
\text { era adequado por estar todo em inglês, além de ser muito caro". }\end{array}$ \\
\hline B & $\begin{array}{l}\text { "Quem decide aquisição e compra são os professores". As editoras entram em contato com a } \\
\text { biblioteca, que pede um trial que varia de um a seis meses. Depois, isso é divulgado na página } \\
\text { da Internet, na Intranet e no Facebook para ser avaliado pela comunidade universitária. Mas } \\
\text { o peso maior é do professor. A Ebrary foi escolhida pela multidisciplinaridade, pela facilidade } \\
\text { de uso e por oferecer treinamentos. }\end{array}$ \\
\hline C & "A escolha é feita pela obra, e não pelo fornecedor. O fornecedor está no fim da linha". \\
\hline D & $\begin{array}{l}\text { "Inicialmente nós buscamos as editoras renomadas, nós ainda não pegamos as pequenas e } \\
\text { médias editoras." }\end{array}$ \\
\hline E & $\begin{array}{l}\text { "Já eram comprados livros impressos com essas editoras e elas ofereceram o livro } \\
\text { eletrônico". }\end{array}$ \\
\hline F & $\begin{array}{l}\text { "O primeiro teste foi feito com a Pearson, que veio vinculado junto com a base de dados que } \\
\text { nós temos da EBSCO"... }\end{array}$ \\
\hline G & $\begin{array}{l}\text { Mesmo do livro impresso. A biblioteca possui um contrato de fornecimento de livros que } \\
\text { prevê a aquisição de livros eletrônicos. }\end{array}$ \\
\hline H & Pelo Google, por indicação de um servidor e um fornecedor de materiais impressos. \\
\hline I & Análise dos produtos. \\
\hline J & O vendedor geralmente procura a gente e oferece um trial. \\
\hline
\end{tabular}

Fonte: Autoria própria.

A inspiração para a pergunta 13 surgiu a partir de Grigson (2011), que afirmou que as informações sobre a disponibilidade de um livro em formato eletrônico e com qual vendedor ele pode ser comprado não são encontradas facilmente. A maioria das bibliotecas sequer teve essa dificuldade para encontrar o vendedor, pois foram eles que ofereceram seus produtos para elas.

A biblioteca A, onde o processo de compra começou pela escolha do aparelho, preferiu comprar de um vendedor brasileiro, para facilitar o atendimento e diminuir a burocracia da compra.

Nas bibliotecas B, E e J os vendedores buscaram as bibliotecas, e não o contrário. É interessante perceber esse movimento onde a inovação vem de fora para dentro, e não a partir de uma iniciativa consciente da própria biblioteca, como foi o caso das outras. Isso também aconteceu com a biblioteca $\mathrm{F}$, que escolheu o vendedor a partir do teste de uma base que era vinculada à outra assinatura da biblioteca.

A biblioteca C priorizou a seleção por título para todo o processo de compra. Se a biblioteca precisava de um título fazia o que era necessário para comprá-lo, mesmo que isso significasse a aquisição de um pacote completo. Diferentemente de outras bibliotecas, que aceitavam a compra de obras similares que tratassem do mesmo assunto. 
Já a biblioteca D decidiu começar a comprar os livros eletrônicos pelas editoras grandes, renomadas. Essa é uma maneira de tentar garantir a qualidade do material comprado e do sucesso da compra como um todo. Como já possuem a confiança dos bibliotecários por seus materiais impressos, essas editoras também são priorizadas na compra de materiais eletrônicos. Além disso, a biblioteca $\mathrm{D}$ também decidiu selecionar os vendedores de acordo com o modelo de negócios oferecido: "Então deixamos de comprar só o acesso e passamos a comprar o conteúdo. Isso inclusive está previsto na nossa próxima política. Só vamos comprar livros eletrônicos das editoras que nos permitem comprar o conteúdo" (BIBLIOTECA D). Isso expressa uma exigência não apenas de comprar um material de qualidade, mas também de garantir o acesso a esse material.

As bibliotecas E, G e H citaram os vendedores de livros impressos como fonte para a compra de livros eletrônicos também. Doucette e Lewontin (2012) afirmam que as editoras com as quais a biblioteca compra livros impressos são a melhor fonte de informações sobre publicações a serem lançadas, além de serem a única fonte de preço institucional.

Morris e Sibert (2011) mencionam a facilidade na aquisição de livros eletrônicos com um distribuidor, já que essa compra pode ocorrer simultaneamente com a do livro impresso. No caso da biblioteca $\mathrm{G}$, onde a aquisição de livros eletrônicos está em caráter experimental, quem fornece os livros eletrônicos é o mesmo livreiro dos impressos, em um formato pouco funcional. A biblioteca $\mathrm{G}$ apenas informa quais são os títulos que deseja, o livreiro então os compra por acesso perpétuo e repassa para a biblioteca. Como existe o intermédio de terceiros, o único aspecto da compra decidido pela biblioteca é o título a ser adquirido.

A biblioteca $\mathrm{H}$ foi mais criativa na busca dos fornecedores e utilizou o Google para tentar descobrir quais eram os vendedores de livros eletrônicos. Uma das bases adquiridas foi indicada por um servidor e outra foi apresentada por um fornecedor de quem já comprava material impresso.

A biblioteca I analisou todos os produtos que eram oferecidos, e desses apenas dois não estavam em fase de elaboração. Segundo o entrevistado, as plataformas que surgem primeiro são as das editoras maiores, seguidas pelas editoras menores.

$\mathrm{O}$ entrevistado da biblioteca $\mathrm{J}$ recomendou que antes da compra os bibliotecários devem entrar em contato com os seus colegas para saber se usam o mesmo produto e qual é a opinião deles, se vale a pena ou não. O primeiro critério para avaliar a compra é a qualidade do material da plataforma, e depois é muito importante que seja feito um teste da plataforma. 
A pergunta 14 indagou "De quais vendedores você compra livros eletrônicos". No quadro 15 constam todos os vendedores dos quais as bibliotecas da pesquisa compraram livros eletrônicos e as classificações dos tipos de vendedores de acordo com os entrevistados.

Quadro 15 - Vendedores de livros eletrônicos

\begin{tabular}{|l|l|l|}
\hline 14. De quais vendedores você compra livros eletrônicos? \\
\hline Empresas nacionais & Biblioteca & $\mathbf{1 6}$. Tipo de vendedor \\
\hline Fórum & D, H, I & Editora \\
\hline Livraria Cultura & A & Livraria (Distribuidor) \\
\hline Livreiro & G & Distribuidor \\
\hline Minha Biblioteca & F & Agregador \\
\hline Revista dos Tribunais & H & Editora \\
\hline Saraiva & J & Editora \\
\hline & & \\
\hline Empresas estrangeiras & & \\
\hline CABI & E & Editora \\
\hline \multirow{2}{*}{ Ebrary } & B & Editora \\
\cline { 2 - 3 } & H & Agregador \\
\hline Elsevier & C, E & Editora \\
\hline McGraw-Hill & C & Editora \\
\hline Pearson (EBSCO) & F & Agregador \\
\cline { 2 - 3 } & J & Editora \\
\hline Safari Books & H & Agregador \\
\hline Springer & E & Editora \\
\hline V-lex & J & Agregador \\
\hline
\end{tabular}

Fonte: Autoria própria.

Foram identificados seis vendedores nacionais e oito estrangeiros, num total de 14 vendedores diferentes. É interessante observar que em alguns casos um mesmo vendedor foi classificado de maneira diferente por dois entrevistados. Isso comprova a afirmação de Roncevic (2013) que diz que nem sempre as diferenças entre editoras, agregadores e distribuidores são claras no mercado de livros eletrônicos. Além disso, por terem sido classificadas pelos respondentes, as classificações podem não ser exatas.

A Minha Biblioteca, que foi vista pela biblioteca F como um agregador, foi classificada por Resende (2014) como uma editora, por ser um grupo de editoras que se uniram para facilitar o processo de venda. A Minha Biblioteca não seria um agregador por não ser uma empresa formada por terceiros que licencia o conteúdo das editoras, mas sim a própria reunião das editoras.

A Pearson recebeu classificações diferentes devido às suas características. Ela foi classificada pela biblioteca J como editora, e pela biblioteca F e por Resende (2014) como agregador. Essa confusão foi explicada pelo entrevistado da biblioteca F: 
São agregadores porque eles juntam vários selos editoriais em um só. A Pearson a gente pensa logo na editora, mas tem a Intersaber, a Papyrus, outros selos dentro da Pearson. São livros que tem versão eletrônica que estão lá. São outros títulos que eles recebem autorização para divulgar dentro da biblioteca deles (BIBLIOTECA F).

Ao se observarem as divergências nas classificações da Pearson e da Minha Biblioteca é possível ver que as diferenças são tênues. Apesar da Pearson também reunir várias editoras, ela seria um agregador pois nesse caso uma editora maior recebe autorização das menores para oferecer o seu conteúdo. Diferente da Minha Biblioteca, onde as próprias editoras se uniram e possuem a mesma força no grupo.

Outra empresa onde houve divergência foi a Ebrary, que foi classificada pela biblioteca B como editora, e por Resende (2014) e pela biblioteca H como agregador. Essas divergências mostram que a classificação dos vendedores em editoras, distribuidores e agregadores não é simples e nem clara. Esses são conceitos novos que ainda não estão bem definidos, como afirma Roncevic (2013).

A questão "15. Esse é o mesmo vendedor do qual a biblioteca compra livros impressos?" dá mais informações sobre o perfil do vendedor de livros eletrônicos. Em quatro bibliotecas (D, E, G e H) ele é o mesmo vendedor dos livros impressos.

As bibliotecas de órgãos públicos adquirem seus materiais por licitação, e por isso a maior parte do material impresso é adquirida com livreiros que não são escolhidos diretamente pela biblioteca. Já a compra de livros eletrônicos na maioria das vezes é acompanhada por uma carta de exclusividade, o que significa que a biblioteca escolhe diretamente de quem vai comprar, de acordo com o material que pretende adquirir. Nesse caso existe a inexigibilidade de licitação, que só ocorre por não haver outra empresa que venda os mesmos livros que interessam à biblioteca. Se houver outra empresa que possa fornecer os mesmos livros, o processo de licitação deverá ser feito normalmente (MARINS, 2015).

Devido a essas diferenças no processo de compra de livros impressos e eletrônicos em muitos casos a biblioteca pode possuir o mesmo livro nesses dois formatos, mas cada um é comprado de um vendedor diferente. Assim, as respostas para essa pergunta também dependem da interpretação do entrevistado, que pode entender que o vendedor é o mesmo apenas se o pagamento foi feito para a mesma empresa ou que ele é o mesmo se a biblioteca possuir livros da mesma editora em formatos diferentes.

Por causa das particularidades da aquisição por licitação de livros impressos e eletrônicos, dificilmente o pagamento será realizado para a mesma empresa nos dois casos. A compra de livros impressos por licitação costuma ser feita por meio de um livreiro. E no caso 
do livro eletrônico, nessa pesquisa, a maior parte das compras é feita com as editoras, seguidas pelos agregadores e distribuidores.

A resposta da biblioteca D ilustra bem essa questão:

Sim, compramos livros impressos dessa editora, mas a negociação não é feita diretamente com eles. Compramos os livros dessa editora com o fornecedor que nos dá desconto. Agora o livro digital em si, é importante deixar bem claro que os fornecedores nacionais em sua maioria vendem livros digitais de forma exclusiva. É tanto que eu não caio nem na regra da licitação de fazer por maior desconto, porque não tem fornecedor, eu faço sempre por inexigibilidade (BIBLIOTECA D).

A questão “16. O vendedor é um distribuidor, agregador ou editora?" busca identificar qual foi o tipo de vendedor escolhido.

As bibliotecas A e G, que compraram de distribuidores, adquiriram poucos livros eletrônicos. Elas parecem estar testando o funcionamento desses livros em suas bibliotecas. Assim, pelo menos dentro do universo dessa pesquisa, os distribuidores foram escolhidos para uma compra inicial, de teste, pois permitiam que fossem comprados poucos livros, escolhidos por título. Nesse caso, eles foram a melhor escolha para bibliotecas com pouco orçamento para a compra de livros eletrônicos, e não ofereciam modelos de compra flexíveis.

Prevendo a solicitação de livros eletrônicos a biblioteca $\mathrm{G}$ decidiu incluí-los no contrato feito com o livreiro. A vantagem da compra simultânea de livros impressos e eletrônicos com distribuidores foi citada por Morris e Sibert (2011). Mas essa é uma situação provisória e a biblioteca pretende fazer um estudo sobre as bases para fazer uma assinatura, que ainda não foi feita devido a cortes no orçamento.

A maioria das compras, que foi o caso de sete bibliotecas (B, C, D, E, H, I e J), foi feita diretamente com as editoras. O que pôde ser observado nessa pesquisa foi que, aparentemente, quando uma editora decide entrar no mercado de livros eletrônicos, ela monta a sua própria plataforma e começa a comercializá-la ainda no período de teste, antes que o seu desenvolvimento seja concluído. Esse foi o caso de muitas editoras brasileiras, e a biblioteca D relata que na área do Direito são sempre as editoras que vendem os seus próprios livros. Cada uma dessas editoras possui o seu próprio modelo de venda que costuma ser bem diferente das outras. Morris e Sibert (2011) afirmam que muitas editoras não utilizam agregadores para cortar o intermediário no fluxo comercial.

Não seria melhor se todas entrassem em um consenso e se unissem em uma plataforma única, maior e com mais recursos? Assim seria possível oferecer um produto mais completo e mais coeso para a biblioteca, que não precisaria lidar com tantos vendedores, modelos de 
negócios e compras diferentes. Como afirma Grigson (2011), a desvantagem das editoras é que cada uma costuma oferecer apenas os seus próprios títulos.

Apenas três bibliotecas compraram de agregadores (F, H e J), e cinco vendedores foram classificados dessa maneira, sendo que apenas um agregador é internacional. Os agregadores reúnem grandes editoras em uma única plataforma. Mesmo que eles não reúnam todos os livros eletrônicos que a biblioteca necessita, possuem a vantagem de agregar muitos deles, evitando que o usuário necessite pesquisar ou navegar em várias plataformas, e que a biblioteca precise lidar com vários contratos de compra (RONCEVIC, 2013).

Levando-se em conta que as bibliotecas A e G estão em fase experimental com os livros eletrônicos, cinco das oito bibliotecas (C, E, F, H e J) que não estão em fase experimental precisaram comprar de dois ou mais vendedores para terem os livros eletrônicos que necessitavam. A biblioteca I, que atualmente compra de apenas um vendedor, já estava estudando seriamente a proposta da Editora Revista dos Tribunais. A biblioteca G que até o momento da entrevista havia comprado menos de dez livros eletrônicos também estava analisando, desde 2013, a proposta de outras empresas para a aquisição de uma quantidade maior de livros, e ainda não havia realizado a compra por cortes no orçamento.

Devido à exclusividade do conteúdo oferecido cada vendedor possui uma base que inclui materiais que não estão disponíveis nas outras. Por isso as bibliotecas precisam comprar de vários vendedores diferentes para ter o que necessitam (GRIGSON, 2011). Levando-se em conta a preferência da maioria das bibliotecas entrevistadas em manter os livros nas plataformas dos vendedores (apenas duas possuem plataformas próprias, e ainda assim sem abrir mão das plataformas dos vendedores), o acesso ao material comprado é difuso, pois obriga o usuário a acessar e, na maioria das vezes, pesquisar em bases diferentes para encontrar o material. Isso é uma barreira na utilização desse material, pois dificulta que ele seja encontrado pelos usuários. Por estarem em bases separadas, apenas encontrarão os livros eletrônicos aqueles usuários que já estiverem procurando por eles e que já tiverem conhecimento de suas plataformas. Isso acaba com a serendipidade, a descoberta de materiais diferentes, não esperados, que não foram diretamente pesquisados, mas que poderiam ser encontrados em uma busca por assunto em uma pesquisa única.

Nesse ponto as ferramentas ou serviços de descoberta, que prometem integrar o conteúdo do catálogo da biblioteca com outros produtos adquiridos separadamente e que se encontram em plataformas distintas, podem ser extremamente úteis no processo de descoberta. Entretanto, na hora de acessar o material o usuário ainda deverá lidar com plataformas que 
possuem interfaces diferentes, o que pode ser muito confuso, principalmente para os menos experientes, causando certo desconforto na experiência de uso desse material.

As ferramentas ou serviços de descoberta facilitam a pesquisa dos usuários em plataformas diferentes, quando os livros eletrônicos não estão integrados ao catálogo, ou quando a biblioteca assina mais de uma plataforma. Eles são a evolução dos metabuscadores, e a diferença entre eles é que enquanto o metabuscador vai em busca da informação indexada nas outras bases, o serviço de descoberta inclui as indexações em seu serviço antes da pesquisa (MARINS, 2015). Ou seja, o serviço de descoberta faz uma pré-indexação.

Para isso, a empresa que oferece o serviço de descoberta necessita que as outras empresas das quais a biblioteca compra livros eletrônicos ou outros produtos que ela queira incluir na busca forneçam os dados das indexações antecipadamente (MARINS, 2015). Por isso já surgiram alguns atritos com a Editora Revista dos Tribunais, que aparentemente já se recusou a oferecer esses dados.

A vantagem da pré-indexação dos serviços de descoberta é que são oferecidas mais possibilidades de busca com diferentes tipos de ligações, incluindo o FRBR, com a ideia de unir diferentes expressões da mesma obra, como por exemplo um livro, a sua tradução e o seu filme (MARINS, 2015).

De acordo com Marins (2015), alguns exemplos de serviços de descoberta que podem ser adquiridos pelas bibliotecas são o EDS (EBSCO), o Primo (Ex Libris) e o Summon (Proquest). Também existe o VuFind, que é um software livre de código aberto apoiado pelo IBICT. A composição de preço dos serviços de descoberta é confusa, assim como a dos livros eletrônicos. O preço é calculado de acordo com o número de bases mais o número de registros. Entretanto, existe algo chamado de "resolvedor" de links, que é fundamental para o serviço pois indica onde o conteúdo pode ser encontrado, que tem sido vendido separadamente pelas empresas (MARINS, 2015).

A pergunta 17 indagou "Quais critérios foram levados em conta na hora da compra". As respostas constam no quadro 16. 
Quadro 16 - Critérios levados em conta na hora da compra

\begin{tabular}{|l|l|}
\hline \multicolumn{2}{|l|}{ 17. Quais critérios foram levados em conta na hora da compra? } \\
\hline A & $\begin{array}{l}\text { Foram os mesmos critérios de seleção normais. A biblioteca procura comprar livros } \\
\text { digitais mais atrativos, e não livros de referência, pois isso dificultaria a consulta. }\end{array}$ \\
\hline B & $\begin{array}{l}\text { Avaliação da comunidade universitária: primeiro os professores, depois os alunos } \\
\text { de mestrado e doutorado, estudantes de graduação e funcionários. }\end{array}$ \\
\hline C & A qualidade do livro, independente do vendedor. \\
\hline D & O renome da editora. \\
\hline E & $\begin{array}{l}\text { A editora, a qualidade dos trabalhos, a credibilidade da editora. Principalmente a } \\
\text { editora. }\end{array}$ \\
\hline F & O assunto. \\
\hline G & A solicitação do usuário de determinado título em formato eletrônico. \\
\hline H & A rapidez na disponibilização (não passa por processo técnico). \\
\hline I & O acesso, o interesse dos servidores e a qualidade do material. \\
\hline J & Qualidade de funcionamento e de produto. \\
\hline
\end{tabular}

Fonte: Autoria própria.

Para Vergueiro (2010) existem quatro considerações abrangentes para o início do processo de seleção: o assunto, o usuário, o documento e o preço. Além desses existem também outros critérios que podem ser divididos em três grupos (VERGUEIRO, 2010):

1. Critérios que abordam o conteúdo dos documentos: autoridade, precisão, imparcialidade, atualidade e cobertura/tratamento;

2. Critérios que abordam a adequação ao usuário: conveniência, idioma, relevância, interesse e estilo;

3. Critérios relativos a aspectos adicionais do documento: características físicas, aspectos especiais, contribuição potencial e custo.

É possível observar que as considerações e os critérios se confundem nas respostas. O critério mais importante, pois foi citado por quatro bibliotecas (A, B, G e I), foi a relevância do material para o usuário. E, no caso da biblioteca B, os usuários participam ativamente dessa seleção por meio do período de testes. Na biblioteca $\mathrm{G}$ a aquisição dos livros eletrônicos apenas é feita quando solicitada por um usuário. Nesse caso, a seleção vai além do conhecimento do usuário proposto por Vergueiro (2010), e é feita diretamente por ele. Isso acontece de maneira mais direta no modelo de aquisição orientada pelo usuário (PDA), que não foi utilizado por nenhuma biblioteca da pesquisa.

Três bibliotecas (C, I e J) mencionaram a qualidade, se referindo ao conteúdo dos documentos presentes nas plataformas. A qualidade abrange a autoridade das editoras citadas pelas bibliotecas D e E. Essas são as mesmas editoras nas quais o bibliotecário já confia pela qualidade de seus livros impressos. Entretanto, surge um fator novo que foi mencionado pela biblioteca $\mathrm{J}$, que é a qualidade de funcionamento da plataforma. Pouco adianta assinar uma 
plataforma cujo conteúdo é de reconhecida qualidade e relevância se o acesso é precário, se a plataforma passa muitas horas fora do ar, inacessível, ou se o suporte técnico deixa a desejar. Esse é um novo aspecto que surge devido às caraterísticas particulares dos livros eletrônicos.

Outro aspecto novo mencionado pela biblioteca $\mathrm{H}$ é a rapidez na disponibilização do material. Quando os livros eletrônicos são acessados pelas plataformas dos vendedores, basta realizar o pagamento e eles já estarão disponíveis. Assim, existe uma economia de tempo na entrega e no processamento técnico desse material, que fica imediatamente disponível na base.

Uma outra característica da rapidez relacionada aos livros eletrônicos é mencionada pela biblioteca $\mathrm{C}$, que disse que no campo da Medicina a atualidade da informação é muito importante e por isso a fonte principal não são os livros, mas sim os periódicos, que são mais dinâmicos. Além disso, a informação quase sempre está em inglês já que as traduções são demoradas e o seu custo acaba não compensando para as editoras. A publicação de livros eletrônicos, por ser mais ágil, valoriza mais o produto na Medicina, área onde a atualidade e a rapidez são importantes.

Por fim, a biblioteca $\mathrm{F}$ deu prioridade à seleção pelo assunto dos documentos. Essa é uma consideração abrangente, muito utilizada por bibliotecas especializadas.

No quadro 17 constam as respostas da pergunta "18. Foi solicitado um período de teste antes da aquisição? Quem participou dele?", que procurou identificar se houve um período de teste antes da aquisição, e quem participou dele.

Quadro 17 - Período de teste

\begin{tabular}{|l|l|l|}
\hline 18 & Teste? & Quem participou? \\
\hline A & Não. & $\begin{array}{l}\text { "Não, a compra é feita no escuro. O livro é selecionado por assunto, a } \\
\text { opinião de outros leitores é levada em conta, a importância do autor. Mas } \\
\text { não é disponibilizada uma prévia do arquivo digital." }\end{array}$ \\
\hline B & Sim. & Toda a comunidade universitária: professores, alunos e funcionários. \\
\hline C & Sim. & Usuários e bibliotecários. \\
\hline D & Sim. & Bibliotecários. \\
\hline E & Sim. & Bibliotecários e pesquisadores. \\
\hline F & Sim. & Bibliotecários, professores e alunos. \\
\hline G & Não. & \\
\hline H & Sim. & Usuários e bibliotecários. \\
\hline I & Sim. & Funcionários da instituição e pessoal do atendimento. \\
\hline J & Sim. & Alunos, professores e bibliotecários, inclusive das outras unidades. \\
\hline
\end{tabular}

Fonte: Autoria própria.

O teste é mais uma novidade que o material eletrônico, seja ele livro ou periódico, traz para as bibliotecas. Conforme mencionado anteriormente, é o teste que irá permitir que usuários e bibliotecários avaliem na prática se os vendedores cumprem com o que é prometido. No teste é possível avaliar a qualidade do conteúdo disponível e do funcionamento da plataforma. A 
biblioteca D destaca a importância do teste para a compra: "Não há como fazer uma seleção sem fazer o pré-teste" (BIBLIOTECA D).

O teste para escolha da aquisição não precisa ser feito apenas pelos bibliotecários, eles podem ter ajuda nesse processo. Os usuários são aqueles para quem a compra é feita e por isso faz todo o sentido incluí-los nesse processo. Como especialistas no assunto, eles podem avaliar a qualidade do material além de observar extensivamente, em termos de horários e de exploração do conteúdo, o funcionamento da base em uma situação real. É possível observar nas questões sobre o uso (38 a 52) que os bibliotecários não fazem o mesmo uso da base que os usuários, e por isso não conhecem o produto tão bem quanto aqueles que realmente precisam dele. Oito das dez bibliotecas (B, C, D, E, F, H, I e J) tiveram um período de testes, e dessas oito apenas em uma os usuários não participaram (D).

As bibliotecas A e $\mathrm{G}$ não tiveram um período de teste devido ao modelo de aquisição, que nos dois casos foi feita com um distribuidor e com a seleção de títulos individuais. A biblioteca A relatou que foi possível manusear o aparelho leitor de livros eletrônicos e fazer perguntas a um vendedor especializado na livraria, mas não existia visualização prévia dos livros. A biblioteca $\mathrm{G}$ relatou que chegou a avaliar um serviço da EBSCO, mas os usuários não gostaram nem da relevância nem da atualidade da base, e por isso ela não foi assinada.

Então pelo valor e pela qualidade da base eles não tiveram interesse na
aquisição. Eles praticam as duas formas, aquisição perpétua ou assinatura por
determinado período, mas não houve interesse pra [sic] nossa área. A seleção
era por pacote. Os livros eram sobre TI, Tecnologia da Informação e
Comunicação. Eles tinham outras áreas, mas só avaliamos a de TI. Nós só
compraríamos esse pacote. Inclusive existia a possibilidade de acrescentar
outros títulos, de fazer aquisições individuais, acrescentar à nossa própria
coleção, mas não houve muito interesse (BIBLIOTECA G).

Na biblioteca B foi solicitado um período de teste para a Minha Biblioteca, mas este era disponibilizado apenas para os bibliotecários. Nessa biblioteca a prioridade na decisão é dos professores e dos alunos, por isso essa plataforma foi desconsiderada. A plataforma perdeu um cliente por não disponibilizar um período de teste de acordo com as exigências da biblioteca, por não se adaptar às necessidades do cliente. Em outro teste da biblioteca $\mathrm{B}$ o acesso era permitido a qualquer um dentro do IP da universidade. $\mathrm{O}$ teste foi divulgado por $e$-mail, na página da Internet e no Facebook.

$\mathrm{Na}$ biblioteca $\mathrm{C}$ quando há um período de teste ele é divulgado no catálogo online. A bibliotecária também liga para alguns usuários pedindo que avaliem a base, e quando não há retorno ela não é adquirida. 
Para incluir os usuários na avaliação não basta que o teste seja disponibilizado, é importante também que ele seja amplamente divulgado em vários canais diferentes como fizeram as bibliotecas B e C, que utilizaram o catálogo, o e-mail, a página da Internet, o Facebook e o telefone. Além desses, outros meios também podem ser utilizados para que a divulgação do período de testes alcance os usuários, como por exemplo o Twitter e o Instagram.

A biblioteca $\mathrm{J}$ relatou que uma vez comprou uma base sem antes realizar o teste. $\mathrm{O}$ resultado foi que o conteúdo era bom, mas a base não funcionava adequadamente e a biblioteca se recusou a renovar o contrato. Além disso, o entrevistado afirmou que também é necessário perguntar a outros bibliotecários sobre os produtos.

O quadro 18 traz as respostas da pergunta "19. Quais os formatos de livros eletrônicos disponíveis?", que buscou identificar os formatos dos livros eletrônicos comprados.

Quadro 18 - Formatos dos livros eletrônicos

\begin{tabular}{|l|l|}
\hline \multicolumn{2}{|l|}{ 19. Quais os formatos de livros eletrônicos disponíveis? } \\
\hline A & EPUB (livros comprados) e PDF (livros gratuitos). \\
\hline B & PDF e EPUB. \\
\hline C & PDF. \\
\hline D & PDF. \\
\hline E & PDF. \\
\hline F & PDF e EPUB. \\
\hline G & PDF e EPUB. \\
\hline H & PDF e EPUB. \\
\hline I & EPUB e HTML. \\
\hline J & EPUB (formato de livro aberto). \\
\hline
\end{tabular}

Fonte: Autoria própria.

Sete bibliotecas (A, B, F, G, H, I e J) declararam que os livros estão no formato EPUB, oito no formato PDF (A, B, C, D, E, F, G e H) e apenas uma citou o formato HTML (I). Conforme indicado no item 2.2, que trata dos formatos, o EPUB e o PDF são os mais comuns. Quando o acesso aos livros é apenas online, talvez o formato informado pelos entrevistados não seja o real. Isso porque quando esse acesso é online a página consultada apenas transmite as informações retiradas do servidor, e por isso o livro não está necessariamente em PDF ou em EPUB, e provavelmente naquele momento ele existe em alguma linguagem de programação para páginas da Internet, como JAVA ou HTML.

O relato da biblioteca $\mathrm{C}$ mostra que nem o bibliotecário nem o usuário estão satisfeitos, nesse caso, com o formato de acesso online dos livros. Mesmo que algumas plataformas possuam funcionalidades como fazer destaques e adicionar comentários, ainda existem problemas. Por exemplo, no caso da biblioteca C o livro apenas pode ser visualizado capítulo por capítulo, e para seguir com a leitura é necessário clicar no link que leva a cada um dos 
capítulos. Essa navegação não permite uma boa interação do leitor com o livro. Além disso, dentro de um mesmo pacote existem diferentes formas de apresentação dos livros. Isso dificulta a interação do leitor, que precisa aprender como funcionará a leitura para cada livro que é aberto.

\begin{abstract}
A maioria em PDF. Ainda. Isso também é um problema. Porque ele em PDF foi pensado para ser lido em papel, às vezes ele é ruim de ler. [...] Eu acho que ainda estamos longe de chegar em um formato ideal pro livro eletrônico. Para abrir esse capítulo em papel a visualização é muito melhor. Isso para quando você está dando uma folheada no livro. Quando você quer uma coisa muito pontual, aí claro, ele é melhor. Isso aqui [a visualização do livro] é muito variável, depende do livro. Dentro de um mesmo pacote às vezes você tem formas diferentes de apresentação. Você tem que ficar abrindo. Tem muito usuário inclusive que não gosta (BIBLIOTECA C).
\end{abstract}

A partir das respostas é possível observar claramente que ainda não existe um consenso sobre o formato, algumas bibliotecas preferem o EPUB e outras o PDF. A biblioteca D comprará apenas livros em PDF, que podem ser convertidos no formato de preservação PDF/A, pois está preocupada com a preservação digital a longo prazo desses livros. Isso combina com a decisão da biblioteca de comprar apenas por acesso perpétuo. Essas decisões pensadas em conjunto demonstram a preocupação com a continuidade do conteúdo adquirido.

A preservação digital é uma questão atual e de extrema relevância não só por questões de acesso, mas também por motivos econômicos. Os livros em papel não desaparecem das estantes como os livros eletrônicos cujas assinaturas não podem ser renovadas. Assim, esse é um aspecto importante que deve ser levado em conta na hora da compra. E sob o aspecto econômico, é importante garantir que os recursos da biblioteca, que muitas vezes são escassos, não irão desaparecer de um ano para o outro, sendo esse mais um problema que não existe com o acervo físico.

Quando o acesso aos livros da biblioteca D é feito pela plataforma do vendedor, os livros estão em HTML e quando é gerado um PDF, ele não tem a mesma formatação do livro. Assim, a biblioteca exigiu que os arquivos que foram enviados pela editora diretamente para a biblioteca fossem iguais aos que vão para a gráfica, com paginação, para que eles possam ser citados em processos. Como foi mencionado por Lins (2014), o PDF tem conteúdo estático, o que garante que a sua paginação seja a mesma para qualquer dispositivo de leitura.

A pergunta "20. A biblioteca já teve interesse em comprar algum livro eletrônico que não era oferecido para bibliotecas?" busca identificar casos em que os livros já existem em formato eletrônico mas o vendedor se recusa a vender para bibliotecas. 
Em um documento da IFLA para as bibliotecas (IFLA, 2014) eles mencionam que duas grandes editoras dos Estados Unidos já se recusaram a vender livros eletrônicos para as bibliotecas. Isso não parece ser parte da realidade brasileira já que apenas uma biblioteca respondeu "sim" a essa pergunta. Isso é um bom sinal, porque por mais que os modelos sejam restritos, os vendedores não se recusaram a fazer negócios com as bibliotecas.

As bibliotecas A, B, D, E, H, I e J não tiveram problemas com vendedores que se recusaram a fazer negócios com bibliotecas. A biblioteca $\mathrm{F}$ foi a única que respondeu sim a essa pergunta. No caso dessa biblioteca, que assina o Minha Biblioteca, alguns títulos da Editora Atlas já existem em formato eletrônico, mas não estão disponíveis no Minha Biblioteca. $\mathrm{O}$ entrevistado acredita que isso acontece porque o autor não autorizou a publicação do livro nessa base. Nesse caso, se o livro for importante para a biblioteca ele é comprado em formato físico, pois o livro eletrônico:

... gera uma série de problemas que eu acho que vão dificultar mais ainda o acesso. Porque no caso do ebook teríamos que criar uma biblioteca própria digital para deixarmos o ebook lá, para vários alunos terem acesso àquele ebook. E geralmente o ebook tem o acesso restrito também, não é multiusuário, você tem que fazer o download, tem todo esse processo. O livro eletrônico que está sendo adotado hoje pelas bibliotecas não requer download nenhum dele, requer um acesso à página com URL e senha (BIBLIOTECA F).

Nesse caso, por haver uma diferença no formato de compra entre os livros eletrônicos que já foram comprados e aqueles que não foram inseridos na base, a biblioteca optou por desistir de adquirir os livros que não foram incluídos na base em formato eletrônico, optando pela compra em papel, o que gera menos problemas para a biblioteca. Existe a vontade da biblioteca em adquirir esses livros em formato eletrônico, mas devido às dificuldades para compra, a biblioteca opta por não fazê-la.

O problema que a biblioteca $\mathrm{C}$ teve não foi que o livro não era vendido para bibliotecas, mas que ele estava disponível para acesso apenas para uma máquina ou computador específico e não para toda a rede. Essa biblioteca compra livros eletrônicos exatamente por essa necessidade de disponibilizar material em diferentes Estados, então para eles não faz sentido comprar um livro que não funcione em rede. Nesse caso o problema está na falta de adaptação do vendedor à necessidade da biblioteca.

Certa vez a biblioteca $\mathrm{G}$ quis comprar livros da Casa do Código mas isso não foi possível pois eles não fornecem livros eletrônicos para terceiros. O livreiro não podia comprar e repassar para a biblioteca, que comprou apenas a versão impressa do livro por causa dessa limitação 
ocorrida devido à compra ser feita com um distribuidor. Mas a biblioteca poderia ter adquirido o livro eletrônico se tivesse comprado diretamente da editora.

Nos relatos das bibliotecas $\mathrm{C}, \mathrm{F}$ e G é possível perceber que mesmo que o vendedor não tenha se recusado diretamente a vender para bibliotecas, as condições impostas por eles as levaram a desistir da compra.

A pergunta "21. Existe suporte técnico local com atendimento em português?", cujas respostas estão no quadro 19, procurou obter mais informações sobre o suporte técnico oferecido pelos vendedores.

Quadro 19 - Suporte técnico

\begin{tabular}{|l|c|c|c|}
\hline \multicolumn{4}{|c|}{ 21. Existe suporte técnico local com atendimento em português? } \\
\hline Empresas nacionais & Biblioteca & Sim & Não \\
\hline \multirow{2}{*}{ Fórum } & D & X & \\
\cline { 2 - 4 } & H & X & \\
\cline { 2 - 4 } & I & X & \\
\hline Livraria Cultura & A & X & \\
\hline Livreiro & G & & X \\
\hline Minha Biblioteca & F & X & \\
\hline Revista dos Tribunais & H & X & \\
\hline Saraiva & J & X & \\
\hline & & & \\
\hline Empresas estrangeiras & & & \\
\hline CABI & E & X & \\
\hline Ebrary & B & X & \\
\cline { 2 - 4 } & H & & X \\
\hline Elsevier & C & & X \\
\cline { 2 - 4 } & E & X & \\
\hline McGraw-Hill & C & & X \\
\hline Pearson (EBSCO) & F & X & \\
\cline { 2 - 4 } & J & X & \\
\hline Safari Books & H & & X \\
\hline Springer & E & X & \\
\hline V-lex & J & X & \\
\hline
\end{tabular}

Fonte: Autoria própria.

Das empresas nacionais, apenas o livreiro fornecedor da biblioteca $G$ não oferece suporte técnico. Entre as empresas estrangeiras, a CABI, a Pearson, a Springer e a V-lex oferecem suporte técnico local com atendimento em português. Houveram divergências nos casos da Ebrary e da Elsevier. A McGraw-Hill e a Safari Books não oferecem suporte local em português.

O suporte técnico é o canal de comunicação, depois da compra, entre o vendedor e a biblioteca. Quando surgem problemas com as plataformas as reclamações são direcionadas ao suporte. Um bom suporte pode garantir a satisfação do cliente e, consequentemente a renovação da base. Como muitas empresas são estrangeiras, surge a questão de se os suportes delas no 
país são satisfatórios e se esse serviço é oferecido na língua local ou apenas em inglês, o que poderia gerar falhas na comunicação.

O suporte da biblioteca A é com a empresa Kobo, fabricante do aparelho leitor, mas nunca precisaram entrar em contato com eles e resolvem seus problemas por telefone com a Livraria Cultura.

O suporte da Ebrary para a biblioteca B possui atendimento em português e fica no Rio de Janeiro. Apesar da distância, a biblioteca entra em contato com eles por telefone e e-mail e os problemas são resolvidos imediatamente. $\mathrm{O}$ contato da biblioteca $\mathrm{C}$ com o seu suporte é feito por $e$-mail em inglês.

A biblioteca D declarou que um bom suporte técnico faz parte dos seus critérios de compra. A biblioteca compra apenas de vendedores que oferecem atendimento 24 horas por dia nos sete dias da semana, e de bases que se mantenham no ar pelo menos $95 \%$ do tempo.

A biblioteca $\mathrm{G}$ compra livros eletrônicos apenas ocasionalmente e não possui nenhum tipo de suporte, apenas recebe as orientações para baixar os livros. Apesar disso, não tiveram nenhum problema e nem sentiram necessidade de solicitar um suporte anterior ou posterior à compra.

A biblioteca J relatou ter tido dificuldade com a distância física do suporte da Saraiva, que fica em São Paulo. A resolução do problema foi demorada e a biblioteca sentiu falta da presença física de alguém para ajudar.

A pergunta “22. É oferecido treinamento presencial e/ou virtual para a equipe da biblioteca e para os usuários?”, do quadro 20, identifica se o vendedor oferece treinamento para bibliotecários e usuários. 
Quadro 20 - Treinamento

\begin{tabular}{|c|c|c|c|c|c|}
\hline \multicolumn{6}{|c|}{$\begin{array}{l}\text { 22. É oferecido treinamento presencial e/ou virtual para a equipe da biblioteca e para os } \\
\text { usuários? }\end{array}$} \\
\hline Empresas nacionais & Biblioteca & Presencial & Virtual & $\begin{array}{l}\text { Bibliotecár } \\
\text { ios }\end{array}$ & Usuários \\
\hline \multirow[t]{3}{*}{ Fórum } & $\mathrm{D}$ & $\mathrm{X}$ & $\mathrm{X}$ & $\mathrm{X}$ & \\
\hline & $\mathrm{H}$ & & $\mathrm{X}$ & $\mathrm{X}$ & \\
\hline & I & $\bar{X}$ & & $\bar{X}$ & \\
\hline Livraria Cultura & $\mathrm{A}$ & - & - & - & - \\
\hline Livreiro & $\mathrm{G}$ & - & - & - & - \\
\hline Minha Biblioteca & $\mathrm{F}$ & $\mathrm{X}$ & $\mathrm{X}$ & $\mathrm{X}$ & $\mathrm{X}$ \\
\hline Revista dos Tribunais & $\mathrm{H}$ & & $\mathrm{X}$ & $X$ & \\
\hline Saraiva & $\mathrm{J}$ & & $\mathrm{X}$ & $\mathrm{X}$ & $\mathrm{X}$ \\
\hline \multicolumn{6}{|l|}{ Empresas estrangeiras } \\
\hline CABI & $\mathrm{E}$ & $\mathrm{X}$ & $\mathrm{X}$ & $\mathrm{X}$ & $\mathrm{X}$ \\
\hline \multirow[t]{2}{*}{ Ebrary } & $\mathrm{B}$ & $X$ & $\mathrm{X}$ & $\mathrm{X}$ & $\mathrm{X}$ \\
\hline & $\mathrm{H}$ & $\mathrm{X}$ & & $\mathrm{X}$ & \\
\hline \multirow[t]{2}{*}{ Elsevier } & $\mathrm{C}$ & $\mathrm{X}$ & $X$ & $\mathrm{X}$ & \\
\hline & $\mathrm{E}$ & $\mathrm{X}$ & $\mathrm{X}$ & $\mathrm{X}$ & $\mathrm{X}$ \\
\hline McGraw-Hill & $\mathrm{C}$ & $\mathrm{X}$ & $\mathrm{X}$ & $\mathrm{X}$ & \\
\hline \multirow{2}{*}{ Pearson (EBSCO) } & $\mathrm{F}$ & $\mathrm{X}$ & $\mathrm{X}$ & $\mathrm{X}$ & $\mathrm{X}$ \\
\hline & $\mathrm{J}$ & & $\mathrm{X}$ & $\mathrm{X}$ & $\mathrm{X}$ \\
\hline Safari Books & $\mathrm{H}$ & & $\mathrm{X}$ & $X$ & \\
\hline Springer & $\mathrm{E}$ & $X$ & $X$ & $X$ & $\mathrm{X}$ \\
\hline V-lex & $\mathrm{J}$ & & $X$ & $X$ & $X$ \\
\hline
\end{tabular}

Fonte: Autoria própria.

Na biblioteca A não existe treinamento. Os usuários são orientados pelos funcionários sobre como utilizar o aparelho Kobo quando fazem o empréstimo. Na biblioteca G, como os aparelhos não ficam na biblioteca, mas sim nas áreas, não há treinamento algum.

Na maioria das bibliotecas, com exceção apenas de A, G e I, o treinamento virtual está disponível. Esse treinamento é mais conveniente para as empresas, pois fica sempre acessível na plataforma e não há necessidade de enviar um representante até a biblioteca. $\mathrm{O}$ treinamento presencial é oferecido em menos lugares que o virtual, e é realizado nas bibliotecas B, C, D, E, F, H e I.

O treinamento apenas não é oferecido para os bibliotecários nas bibliotecas $\mathrm{A}$ e $\mathrm{G}$, estando presente em todas as outras. Apenas as bibliotecas B, E, F e J declararam oferecer treinamento para os usuários.

O treinamento é fundamental para o uso pleno de todas as funcionalidades da plataforma adquirida. Entretanto, a biblioteca $\mathrm{C}$ relatou que não vê necessidade em fazer treinamentos para os usuários das plataformas de livros eletrônicos, pois elas são muito intuitivas. Na biblioteca F o treinamento é feito apenas com os funcionários da biblioteca, e depois eles mesmos treinam os alunos. 
A biblioteca $\mathrm{J}$ reconhece a importância do treinamento ao dizer que: "Se você quer que o negócio funcione, seja efetivo, você tem que fazer a sua população utilizar. A pessoa só utiliza o que sabe mexer" (BIBLIOTECA J).

O quadro 21 traz as respostas da pergunta "23. Existe material de apoio para treinamento (manuais, guias de referência, tutoriais, vídeos)? O material está em português?”, que indaga se o vendedor oferece material de apoio para treinamento.

Quadro 21 - Material de apoio para treinamento

\begin{tabular}{|l|l|}
\hline $\begin{array}{l}\text { 23. Existe material de apoio para treinamento (manuais, guias de referência, } \\
\text { tutoriais, vídeos)? O material está em português? }\end{array}$ \\
\hline A & $\begin{array}{l}\text { Não, o uso foi intuitivo. "O aparelho vem apenas com uma mini cartilha que mostra } \\
\text { apenas alguns dados básicos". }\end{array}$ \\
\hline B & $\begin{array}{l}\text { "Eles sempre têm tutoriais e cartazes. Pedi inclusive para trazerem mais para } \\
\text { divulgarmos. Eles têm um tutorial que podemos colocar na página, mas também tem } \\
\text { cartazes e outros materiais de consulta". }\end{array}$ \\
\hline C & $\begin{array}{l}\text { "Oferecem tutoriais e cartões com o passo a passo para os usuários que nós não } \\
\text { distribuímos". }\end{array}$ \\
\hline D & Sim, em português. \\
\hline E & Sim, em português. \\
\hline F & Sim, em português. \\
\hline G & Não se aplica. \\
\hline H & $\begin{array}{l}\text { "Tem material de apoio. Da Ebrary tem um folder, um resumo em português. Da } \\
\text { Safari não. Mas é tão intuitivo o vídeo que dá para reconhecer bem". }\end{array}$ \\
\hline I & $\begin{array}{l}\text { "Eles fizeram a apresentação comercial da ferramenta, não é bem um treinamento, é } \\
\text { mais uma explicação da ferramenta em si". }\end{array}$ \\
\hline J & O treinamento virtual fica disponível na base. \\
\hline
\end{tabular}

Fonte: Autoria própria.

O material de apoio auxilia no treinamento e, pode ser utilizado a qualquer momento, além de também auxiliar na divulgação da plataforma. Na biblioteca $\mathrm{A}$, como material de treinamento, existe apenas a cartilha que veio com o aparelho Kobo. A biblioteca G não possui nenhum material de treinamento.

As bibliotecas D, E e F informaram que possuem material de treinamento em português. Na biblioteca I existe apenas a apresentação comercial da ferramenta, que não é exatamente igual a um treinamento.

As bibliotecas B, C, H e J mencionaram os tutoriais, que podem ser textos ou vídeos, que estão sempre disponíveis na plataforma para ensinar sobre o seu funcionamento geral. A vantagem dos tutoriais é que eles podem ser vistos apenas por aqueles que possuem interesse no treinamento, e no momento em que a pessoa mais precisa de ajuda, sem a necessidade da presença física em um determinado lugar em um determinado horário. Ainda assim, é 
importante lembrar que para alguns, como a biblioteca $\mathbf{J}$ mencionou, também é vital que haja um treinamento presencial, onde as pessoas podem interagir e fazer perguntas diretamente ao especialista.

O quadro 22 traz as respostas da pergunta 24, que busca saber se a biblioteca pode obter estatísticas de uso dos livros, e como ela obtém acesso a essas estatísticas.

Quadro 22 - Estatísticas de uso

\begin{tabular}{|c|c|c|c|c|}
\hline \multicolumn{5}{|c|}{$\begin{array}{l}\text { 24. É possível obter estatísticas de uso dos livros eletrônicos? Que tipo de estatísticas estão } \\
\text { disponíveis? }\end{array}$} \\
\hline $\begin{array}{l}\text { Empresas } \\
\text { nacionais }\end{array}$ & $\begin{array}{l}\text { Biblio- } \\
\text { teca }\end{array}$ & Sim & Não & Comentários \\
\hline \multirow[t]{3}{*}{ Fórum } & $\mathrm{D}$ & $\mathrm{X}$ & & $\begin{array}{l}\text { A estatística da plataforma da empresa é enviada por ela, } \\
\text { e a biblioteca tem livre aceso às estatísticas da plataforma } \\
\text { própria. }\end{array}$ \\
\hline & $\mathrm{H}$ & $\mathrm{X}$ & & Estatística enviada pela empresa. \\
\hline & I & $X$ & & $\begin{array}{l}\text { Precisamos solicitar as estatísticas e então eles enviam. } \\
\text { As estatísticas não são detalhadas por livro, informam } \\
\text { apenas os acessos registrados à base naquele período. }\end{array}$ \\
\hline Livraria Cultura & $\mathrm{A}$ & & $\mathrm{X}$ & \\
\hline Livreiro & $\mathrm{G}$ & & & Não se aplica. \\
\hline $\begin{array}{l}\text { Minha } \\
\text { Biblioteca }\end{array}$ & $\mathrm{F}$ & $\mathrm{X}$ & & \\
\hline $\begin{array}{l}\text { Revista dos } \\
\text { Tribunais }\end{array}$ & $\mathrm{H}$ & $\mathrm{X}$ & & Estatística enviada pela empresa. \\
\hline Saraiva & $\mathrm{J}$ & & $\mathrm{X}$ & \\
\hline \multicolumn{5}{|l|}{$\begin{array}{l}\text { Empresas } \\
\text { estrangeiras }\end{array}$} \\
\hline CABI & $\mathrm{E}$ & $\mathrm{X}$ & & \\
\hline \multirow[t]{2}{*}{ Ebrary } & B & $\mathrm{X}$ & & $\begin{array}{l}\text { A própria biblioteca emite os relatórios na plataforma, } \\
\text { com informações sobre livros lidos, downloads feitos, } \\
\text { pesquisas e downloads por área. }\end{array}$ \\
\hline & $\mathrm{H}$ & $\mathrm{X}$ & & $\begin{array}{l}\text { A própria biblioteca emite a estatística no módulo de } \\
\text { administração. Eles fornecem um relatório com o número } \\
\text { de sessões, que é o momento que o usuário entra no } \\
\text { sistema até o momento em que ele termina, mostra os } \\
\text { livros que cada usuário utilizou, quantas vezes ele abriu, } \\
\text { e se ele baixou o livro. Também em que suporte aquele } \\
\text { livro foi lido: se foi no celular, no desktop... }\end{array}$ \\
\hline \multirow[t]{2}{*}{ Elsevier } & $\mathrm{C}$ & $X$ & & \\
\hline & $\mathrm{E}$ & $\mathrm{X}$ & & \\
\hline McGraw-Hill & $\mathrm{C}$ & $\mathrm{X}$ & & \\
\hline \multirow{2}{*}{$\begin{array}{l}\text { Pearson } \\
\text { (EBSCO) }\end{array}$} & $\mathrm{F}$ & $\mathrm{X}$ & & \\
\hline & $\mathrm{J}$ & & $\mathrm{X}$ & \\
\hline Safari Books & $\mathrm{H}$ & $\mathrm{X}$ & & Igual a Ebrary $(\mathrm{H})$. \\
\hline Springer & E & $X$ & & \\
\hline V-lex & $\mathrm{J}$ & & $\mathrm{X}$ & \\
\hline
\end{tabular}

Fonte: Autoria própria. 
As estatísticas estão diretamente ligadas à decisão de renovar ou cancelar a assinatura de um produto. Quando a plataforma é do vendedor, as estatísticas podem ser enviadas por eles periodicamente ou quando solicitado, ou os relatórios podem ser gerados na plataforma pela própria biblioteca. É melhor quando a própria biblioteca emite suas estatísticas. Assim, não é necessário esperar e diminui o risco de manipulação dos dados. As estatísticas mais detalhadas também dão mais segurança ao bibliotecário e facilitam o processo decisório na renovação das assinaturas.

Quase todas as bibliotecas, menos A e J, têm acesso às estatísticas de uso dos livros eletrônicos. A biblioteca $\mathrm{J}$ declarou já ter tido problemas com estatísticas enviadas por uma empresa cujo nome não foi citado. O entrevistado sabia que a utilização era baixa e quando pedia que a empresa enviasse as estatísticas, perto do período de renovação, a utilização era alta. O entrevistado entrou em contato com o vendedor para reclamar, e esse então disponibilizou um meio para que a própria biblioteca emitisse as estatísticas. A partir de então a própria biblioteca passou a emitir as estatísticas e verificou que elas eram totalmente diferentes das que eram enviadas. Essa experiência confirma o que foi dito por Vasileiou, Rowley e Hartley em 2012, quando escreveram que as estatísticas de uso oferecidas pelos vendedores podem ser de baixa qualidade, inconsistentes, inadequadas ou incompletas.

Mesmo que as estatísticas estejam ligadas à decisão de renovação ou cancelamento de um produto, esse não pode ser o único fator que é levado em conta, principalmente se a biblioteca não confia nessas estatísticas. O bibliotecário também deve observar a opinião dos usuários sobre o conteúdo da base e sobre o seu funcionamento.

A pergunta 37 , do quadro 23 , busca descobrir como cada biblioteca decide se as assinaturas serão renovadas ou canceladas. Ela foi deslocada da ordem das perguntas para se encaixar melhor no contexto da análise dos dados. 
Quadro 23 - Critérios de renovação e cancelamento

\begin{tabular}{|l|l|}
\hline $\begin{array}{l}\text { 37. Quais são os critérios utilizados para decidir se a assinatura dos livros será renovada ou } \\
\text { cancelada? }\end{array}$ \\
\hline A & Não se aplica. O acesso é perpétuo. \\
\hline B & "O número de acessos que é feito anualmente". \\
\hline C & $\begin{array}{l}\text { "Existem aquelas assinaturas tradicionais que a gente já assina há muito tempo. Por } \\
\text { exemplo, o principal periódico da área de ortopedia não vai ser cortado mesmo que o uso } \\
\text { naquele ano tenha sido pequeno, o que é raro, porque ele é um periódico importante. Mas eu } \\
\text { tenho estatística de uso, então a gente corta se for o caso". }\end{array}$ \\
\hline D & $\begin{array}{l}\text { São os mesmos critérios da compra, como por exemplo: nível de assunto da matriz, } \\
\text { importância do assunto, estatística de uso, data da última edição, diferença da edição anterior } \\
\text { etc. }\end{array}$ \\
\hline E & $\begin{array}{l}\text { "No caso de assinatura, se tiver recursos, verificamos se está sendo usado, a estatística de } \\
\text { uso". }\end{array}$ \\
\hline F & O uso e acesso. \\
\hline G & Não se aplica. \\
\hline H & Uso e qualidade. \\
\hline I & Uso, preço e qualidade. \\
\hline J & Funcionamento e treinamento. \\
\hline
\end{tabular}

Fonte: Autoria própria.

Sete bibliotecas (B, C, D, E, F, H e I) mencionaram que o uso é um dos fatores, senão o fator principal, na decisão de renovação. Mas, como foi observado na resposta da questão 24, e principalmente no depoimento da biblioteca J, nem sempre essas estatísticas são confiáveis.

Para a biblioteca $\mathrm{D}$, os critérios utilizados na renovação são os mesmos da compra. Assim, todos os fatores são avaliados novamente para que haja a renovação.

Apesar de utilizarem o uso como fator para a renovação, as bibliotecas não utilizam um dado pré-determinado para dizer se o uso é alto. Cada caso é analisado separadamente. A biblioteca $\mathrm{C}$ ressalta que, em alguns casos, mesmo que o uso tenha sido um pouco mais baixo, se a biblioteca considerar que o material sobre aquele tema é relevante para seus usuários a assinatura é mantida.

Três bibliotecas ( $\mathrm{H}, \mathrm{I}$ e $\mathrm{J})$ também mencionaram a qualidade do funcionamento da base de dados como um fator importante. Essa é uma diferença entre uma nova compra e a renovação, já que na renovação a biblioteca também avalia a experiência que já teve com a plataforma e se ela for ruim, como já aconteceu com a biblioteca $\mathbf{J}$, ela pode decidir pelo cancelamento.

O terceiro bloco de perguntas vai da 25 à 28 e trata dos modelos de negócios. A pergunta 25, do quadro 24, busca saber quais são os modelos de negócios praticados pelos vendedores. 
Quadro 24 - Modelos de negócio dos vendedores

\begin{tabular}{|l|l|l|l|}
\hline 25. Que modelos de negócio são praticados pelo fornecedor? \\
\hline Empresas nacionais & Biblioteca & Tipo de vendedor & Modelos \\
\hline Fórum & D, H, I & Editora & $\begin{array}{l}\text { Acesso perpétuo, } \\
\text { Assinatura }\end{array}$ \\
\hline Livraria Cultura & A & $\begin{array}{l}\text { Livraria } \\
\text { (Distribuidor) }\end{array}$ & Acesso perpétuo \\
\hline Livreiro & G & Distribuidor & Acesso perpétuo \\
\hline Minha Biblioteca & F & Agregador & Assinatura anual \\
\hline Revista dos Tribunais & H & Editora & Assinatura anual \\
\hline Saraiva & J & Editora & Assinatura semestral \\
\hline & & & \\
\hline Empresas estrangeiras & & & $\begin{array}{l}\text { Acesso perpétuo, } \\
\text { Assinatura }\end{array}$ \\
\hline CABI & E & Editora & $\begin{array}{l}\text { Acesso perpétuo, } \\
\text { Assinatura }\end{array}$ \\
\hline Ebrary & B & Editora & Assinatura \\
\cline { 2 - 4 } & H & Agregador & Assinatura \\
\hline Elsevier & C, E & Editora & Assinatura \\
\hline McGraw-Hill & C & Editora & Assinatura anual \\
\hline Pearson (EBSCO) & F & Agregador & Assinatura anual \\
\cline { 2 - 4 } & J & Editora & Assinatura \\
\hline Safari Books & H & Agregador & $\begin{array}{l}\text { Acesso perpétuo, } \\
\text { Assinatura }\end{array}$ \\
\hline Springer & E & Editora & Assinatura \\
\hline V-lex & J & Agregador & \\
\hline
\end{tabular}

Fonte: Autoria própria.

$\mathrm{Na}$ análise dos modelos de negócios fica claro que a realidade das bibliotecas entrevistadas está longe da literatura internacional, já que aqui apenas são oferecidos o acesso perpétuo e a assinatura. Santana (2015) mencionou que os modelos de empréstimo de curto prazo e aquisição orientada pelo usuário ainda não foram adotados no Brasil.

Apenas os distribuidores das bibliotecas A e G trabalhavam só com o acesso perpétuo. As empresas Fórum, CABI, Ebrary e Springer ofereciam tanto o acesso perpétuo como a assinatura. Todas as outras empresas ofereciam apenas a assinatura, como pode ser visto no quadro 24.

No caso da biblioteca A, todo o modelo de aquisição não é apropriado para uma biblioteca. A biblioteca comprou o aparelho e os livros da mesma maneira que eles seriam vendidos para uma pessoa física, o que gera muitas limitações no acesso. Os livros podem ser lidos no aparelho da biblioteca e a própria biblioteca coloca a sua senha, que é única, para habilitar o download nos aparelhos de alguns usuários.

"Os usuários acessam o livro pelo Kobo e em aparelhos próprios, mas isso não é divulgado porque a biblioteca tem medo de espalhar algo que ainda está mal definido. A senha de login é a mesma para a compra, o que dificulta para a biblioteca" (BIBLIOTECA A). 
A biblioteca $\mathrm{C}$ disse que a Wiley oferece a aquisição orientada pelo usuário, mas é necessário comprar um pacote de no mínimo 25 títulos. Esse foi o único caso onde a aquisição orientada pelo usuário foi citada. Além disso, das editoras da área da saúde, apenas a Wiley oferecia o acesso perpétuo, todas as outras trabalhavam apenas com a assinatura.

A biblioteca I reconhece que modelos diferenciados ainda não são oferecidos, existem apenas a assinatura e a aquisição. A falta de uma opção como o empréstimo de curto prazo que poderia gerar uma eficiência de custo faz com que bibliotecas e usuários percam no desperdício de recursos e também na relevância do acervo, que poderia ser mais utilizado se pudesse ser selecionado diretamente pelos usuários.

A pergunta “26. Qual foi o modelo escolhido? Por que esse modelo foi escolhido?”, do quadro 25, busca saber o motivo que levou cada biblioteca a optar por um determinado modelo de negócio.

Quadro 25 - Motivo para escolha dos modelos

\begin{tabular}{|l|l|l|}
\hline 26 & Qual foi o modelo escolhido? & Por que esse modelo foi escolhido? \\
\hline A & Acesso perpétuo. & Único. \\
\hline B & Assinatura. & $\begin{array}{l}\text { Porque é o mais barato. O acesso perpétuo é } \\
\text { interessante, mas é muito mais caro. Então por um } \\
\text { ano, a política é de sempre renovar. A escolha foi } \\
\text { mais pelo custo. }\end{array}$ \\
\hline C & Assinatura e acesso perpétuo. & $\begin{array}{l}\text { Poucos livros foram comprados por acesso } \\
\text { perpétuo. A Elsevier possui uma base de Medicina } \\
\text { e apenas os livros que não estão nela podem ser } \\
\text { comprados individualmente. }\end{array}$ \\
\hline D & Acesso perpétuo. & A biblioteca exigiu esse modelo. \\
\hline E & Assinatura e acesso perpétuo. & $\begin{array}{l}\text { Porque a assinatura, quando acaba, você perde o } \\
\text { acesso, então temos preferência por ficar com o } \\
\text { arquivo. }\end{array}$ \\
\hline F & Assinatura. & Único. \\
\hline G & Acesso perpétuo. & Único. \\
\hline H & Assinatura. & Único. \\
\hline I & Assinatura. & Único. \\
\hline J & Assinatura. & Único. \\
\hline
\end{tabular}

Fonte: Autoria própria.

O entrevistado da biblioteca $\mathrm{D}$ explicou que o que nesse trabalho foi descrito como acesso perpétuo ele entende como compra do conteúdo, e a assinatura seria a compra do acesso. É interessante perceber como esses são nomes diferentes que explicam a mesma ideia. Como esses ainda não são conceitos consolidados, é importante apresentar todas as variantes disponíveis que permitem facilitar o entendimento de um assunto tão complexo.

De acordo com o entrevistado da biblioteca $\mathrm{D}$ as empresas não querem fazer o que ele chama de venda do conteúdo, talvez por medo de serem prejudicados por questão de direito 
autoral. Ainda de acordo com ele, a maioria trabalha com assinatura para acesso apenas durante o período de vigência da assinatura. A biblioteca insistiu em assinar apenas se tivesse o conteúdo, e para receber as novas edições durante o período de vigência da assinatura.

Em seis das dez bibliotecas (A, F, G, H, I e J) o modelo de negócio apresentado era a única opção disponível para compra. Duas bibliotecas (C e E) compraram tanto por assinatura quanto por acesso perpétuo, três (A, D e G) compraram apenas por acesso perpétuo e cinco (B, F, H, I e J) apenas por assinatura. Entretanto, das três que compraram por acesso perpétuo, duas estão em fase experimental e compraram menos de quinze livros eletrônicos. Isso leva à reflexão sobre a afirmação anterior da biblioteca $\mathrm{D}$, de que as empresas preferem vender a assinatura. Talvez essa também seja a maneira encontrada por elas de receber mais por um mesmo conteúdo, já que todos os anos a biblioteca precisaria pagar novamente pelos mesmos livros, sem que eles sejam parte do seu acervo por um período indeterminado.

A biblioteca E começou a comprar livros eletrônicos em 2007, mas hoje possui apenas os livros adquiridos por acesso perpétuo, pois desde 2012 não tem condições de renovar a assinatura. A biblioteca D também já perdeu acesso a alguns livros por não renovar uma assinatura. Isso ainda não é algo comum a muitas bibliotecas, já que a maioria ainda está começando a fazer as suas primeiras assinaturas. Entretanto, esses são casos reais onde a opção pela compra por assinatura já fez com que a biblioteca perdesse acesso por decidir cancelar ou não poder renovar o contrato. Como afirmaram Morris e Sibert (2011), o custo de renovação anual pode ser problemático para as bibliotecas.

A biblioteca $\mathrm{C}$, depois de muita luta e pressão sobre os fornecedores, conseguiu garantir o seu direito de acesso ao material pago, mesmo em caso de assinatura. Nesse caso, se a biblioteca não puder renovar continuará tendo acesso ao material que já estava na base no período em que assinou, mas sem as atualizações. Isso é uma revolução pois trata do problema da assinatura mencionado em muitas entrevistas. Mas parece apenas justo que a biblioteca possa usufruir daquilo que foi pago, mesmo que ela não tenha condições de adquirir novos materiais.

A pergunta "27. Em caso de assinatura de pacotes, é possível trocar os títulos que não são utilizados?", busca saber se uma característica específica da compra por pacotes, que é a troca de títulos, está disponível.

Em apenas uma biblioteca (B) havia a opção de trocar os títulos do pacote, e ainda assim ela não era utilizada na prática pois o acervo é muito extenso e a biblioteca não tem condições de controlar e selecionar os livros. Doucette e Lewontin (2012) alertam que quando há troca de títulos o catalogador deve ficar atento para manter o catálogo atualizado e garantir que nenhum 
usuário tente acessar um título que já não está mais disponível. Entretanto, a integração não é tão comum e foi feita por apenas três bibliotecas dessa pesquisa (A, E e F).

Em sete das oito bibliotecas que selecionaram por pacote (C, D, E, F, H, I e J), ele é fechado, sem possibilidade de troca. A biblioteca $E$ ressaltou que o contrato é feito com aqueles títulos, e por isso não tem a flexibilidade de troca. A troca seria mais uma ferramenta de otimização do dinheiro, permitindo que a biblioteca substitua títulos não utilizados por outros com maior potencial.

A questão “28. Existe um limite fixo de número de acessos por título?” busca analisar se o livro expira depois de um certo número de acessos, e não deve ser confundida com a questão 55, que trata do limite de acessos simultâneos à plataforma. Esse modelo onde há um limite de empréstimos para um título não foi adotado por nenhuma das bibliotecas entrevistadas. Isso é uma boa notícia já que esse modelo foi criado para simular a utilização de um livro impresso, que teoricamente se torna inutilizável depois de um número determinado de empréstimos. Assim, quando é adotado, é como se os livros gastos da biblioteca desaparecessem da estante.

As respostas das questões 28 e " 53 . O acesso é de apenas um usuário por vez, múltiplo (2, 3 pessoas) ou ilimitado por livro?" foram mescladas, e podem ser vistas no quadro 27 , já que em nenhum caso as bibliotecas tiveram que lidar com limites por livro, eles são apenas para a base como um todo.

A biblioteca $\mathrm{F}$ nunca teve problemas com os vendedores por causa de livros que são muito utilizados. Mas na biblioteca $\mathrm{E}$ o vendedor entrou em contato com eles porque uma unidade da biblioteca começou a baixar muitos livros que interessavam a ela com medo que eles saíssem do ar. A biblioteca sede entrou em contato com eles para explicar que o download não pode ser realizado indiscriminadamente.

As perguntas 53 a 55, que são o bloco que trata dos modelos de acesso dos usuários, foram retiradas da sua ordem numérica para se encaixarem melhor na análise. A pergunta 55, que consta no quadro 26, procurou saber se existe um limite de acessos simultâneos à plataforma, e qual é esse limite. 
Quadro 26 - Limite de acessos simultâneos à plataforma

\begin{tabular}{|c|c|c|c|}
\hline \multicolumn{4}{|c|}{ 55. Há um limite máximo de acessos simultâneos à plataforma? } \\
\hline & Não & Sim & Qual? \\
\hline A & - & - & Não se aplica. O acesso depende do aparelho onde o livro foi baixado. \\
\hline B & $\mathrm{X}$ & & \\
\hline $\mathrm{C}$ & & $\mathrm{X}$ & $\begin{array}{l}\text { Para a McGraw Hill eles possuem um limite de } 15 \text { acessos simultâneos à } \\
\text { plataforma. }\end{array}$ \\
\hline $\mathrm{D}$ & $\mathrm{X}$ & & \\
\hline $\mathrm{E}$ & $\mathrm{X}$ & & \\
\hline $\mathrm{F}$ & $\mathrm{X}$ & & \\
\hline $\mathrm{G}$ & - & - & Não se aplica. $\mathrm{O}$ acesso depende do aparelho onde o livro foi baixado. \\
\hline $\mathrm{H}$ & & $\mathrm{X}$ & Só 120 usuários (licenças) podem utilizar a base Safari simultaneamente. \\
\hline $\mathrm{I}$ & $\mathrm{X}$ & & \\
\hline $\mathbf{J}$ & & $\mathrm{X}$ & $\begin{array}{l}\text { Saraiva - "Tem um número de usuários, mas o acesso não é limitado. Então } \\
\text { assim, o meu contrato com a Saraiva eu acho que foi de } 3.600 \text { usuários } \\
\text { simultâneos, só pra [sic] cá. Na verdade, sempre pedimos um número de } \\
\text { acessos alto para poder atender a todo mundo." O número de acessos foi } \\
\text { escolhido livremente pelo comprador (não é por faixas), e é diferente para cada } \\
\text { unidade da rede pois foi feito de acordo com o número de alunos. }\end{array}$ \\
\hline
\end{tabular}

Fonte: Autoria própria.

Essa pergunta não se aplica às bibliotecas A e G, onde o acesso não é feito por plataforma. As plataformas das bibliotecas B, D, E, F e I não possuem um limite de acessos simultâneos.

Apesar de não terem relatado limites de acesso por título, o limite de acessos simultâneos às plataformas faz parte da realidade de três bibliotecas $(\mathrm{C}, \mathrm{He} \mathrm{J})$. Em alguns casos, o limite é simultâneo para quaisquer usuários. Mas uma novidade que não havia aparecido na revisão de literatura é a venda de licenças. Dessa maneira, o vendedor limita o número de usuários totais da biblioteca que podem utilizar a plataforma, e essa limitação é a qualquer hora, e não simultânea. Nesse caso, apenas um número limitado de usuários pode se cadastrar para utilizar a plataforma. E apenas os usuários cadastrados, que são em número pré-determinado, poderão utilizar a plataforma.

$\mathrm{O}$ entrevistado da biblioteca $\mathrm{C}$ explicou que o preço do acesso à McGraw Hill é dividido por faixas de 1, 5, 10, 15, 20 acessos em diante. Primeiro a biblioteca comprou 5 acessos para testar e como teve problemas foi aumentando até chegar a 15, que foi considerado razoável pois a cada novo nível de 5 usuários o preço aumenta muito.

É interessante observar o caso específico da Editora Revista dos Tribunais mencionado pela biblioteca I. De acordo com eles, para esse vendedor, o acesso por IP é ilimitado. Mas quando o acesso é por usuário e senha, a base é limitada ao número de usuários comprados. Aparentemente, por IP o risco de utilização indiscriminada dos livros é menor, pois o IP é ligado à instituição que fez a compra, e por isso o acesso é ilimitado. Entretanto, o acesso por usuário 
e senha pode ter sido considerado mais perigoso pelo vendedor, e por isso é limitado a um número determinado de usuários. Essas são apenas suposições feitas na tentativa de entender a lógica utilizada pelo vendedor ao atrelar o limite à forma de acesso.

Quando a venda é por número de licenças ou acessos simultâneos à base, os vendedores oferecem um número extra de acessos "grátis". Assim, mais usuários da biblioteca passam a conhecer o produto. No ano seguinte, o vendedor começa a cobrar por esses acessos que eram grátis pois os usuários já possuem esse acesso e já estão fidelizados à empresa. Além disso, muitos usuários fazem o cadastro e só utilizam a base por um curto período de tempo, ocupando o lugar que poderia ser de outro. É como se a biblioteca tivesse um número limitado não de livros, mas de cadeiras. Na biblioteca $\mathrm{H}$, o bibliotecário se sentiu obrigado a cortar os usuários que não utilizaram a base em um período de 90 dias. Dessa maneira o vendedor limita os usuários, e não os livros. Alguém é expulso da biblioteca se passar muito tempo sem ir? Isso é o que acontece quando existe um número limitado de cadastros de usuários.

É importante atentar que o uso de várias bases com modelos de acesso diferentes pode confundir muito o usuário sobre quais são as regras e limites de uso para cada uma. Em algumas bases, o acesso simultâneo é ilimitado. Já em outras, ele é limitado aos acessos comprados pela biblioteca. Em outros casos, apenas podem acessar a base aqueles usuários que estão dentro das licenças compradas pela biblioteca. Nem sempre o usuário saberá como funciona o acesso para cada plataforma, e depois de ter o acesso negado sem entender o motivo pelo qual isso aconteceu, o usuário pode desistir de acessar a base.

Por serem complementares, as perguntas 53 e 54 estão no quadro 27. Juntas, elas identificam qual é o modelo de acesso e porque ele foi escolhido.

Quadro 27 - Modelo de acesso

\begin{tabular}{|l|l|l|}
\hline \multicolumn{2}{|l|}{$\mathbf{5 3}$ Acesso } & 54. Por que esse modelo foi escolhido? \\
\hline A & Múltiplo. & Só tinha esse modelo. \\
\hline B & Ilimitado. & $\begin{array}{l}\text { Para que todos possam ler ao mesmo tempo, já que a universidade tem muitos } \\
\text { alunos e usuários externos. }\end{array}$ \\
\hline C & Ilimitado. & $\begin{array}{l}\text { "Na verdade, a gente não escolhe o modelo, a gente escolhe a obra. E a partir } \\
\text { disso a gente tem que se adaptar ao modelo sob o qual a obra é comercializada". }\end{array}$ \\
\hline D & Ilimitado. & "Para que todos os funcionários possam ter acesso". \\
\hline E & Ilimitado. & Só tinha esse modelo. \\
\hline F & Ilimitado. & $\begin{array}{l}\text { Só tinha esse modelo. Isso foi usado como peso favorável para escolha das duas } \\
\text { bases, ser multiusuário, para todos poderem usar ao mesmo tempo. }\end{array}$ \\
\hline G & $\begin{array}{l}\text { Um por } \\
\text { vez. }\end{array}$ & Único devido ao vendedor. \\
\hline H & Ilimitado. & Não foi informado. \\
\hline I & Ilimitado. & Só tinha esse modelo. \\
\hline J & Ilimitado. & Só tinha esse modelo. \\
\hline
\end{tabular}

Fonte: Autoria própria. 
Em oito bibliotecas (B, C, D, E, F, H, I e J) o modelo de acesso aos livros eletrônicos é ilimitado. Na biblioteca A o acesso é múltiplo pois o download do livro pode ser feito em mais de um aparelho. Na biblioteca G o acesso é limitado a um usuário por vez, pois, devido ao modelo de compra, para cada livro é feito um download único no tablet da área.

A questão 54, que complementava a 53, mudou de foco, pois como não havia nenhum limite por livro ela foi respondida como a 55, que trata dos limites por plataforma. Ainda assim, a partir dela é possível entender porque os limites para as plataformas foram escolhidos. Seis bibliotecas (A, E, F, G, I e J) declararam que o modelo escolhido era o único disponível. Mais uma vez, uma série de respostas mostra que as bibliotecas não têm opções para a compra já que os modelos são únicos. Entretanto, para as bibliotecas B, C e F, apesar dos modelos únicos, estes eram a melhor opção para atender às suas necessidades.

Na biblioteca E, a aquisição foi feita por acesso perpétuo e o entrevistado informou que não precisou pagar nada além do preço dos livros para fornecer o acesso a todas as unidades da biblioteca.

A biblioteca B escolheu o modelo de acesso ilimitado para que todos os usuários, inclusive os externos, pudessem ler os livros simultaneamente. A biblioteca D também escolheu o modelo ilimitado para que todos os funcionários tenham acesso. A biblioteca $\mathrm{C}$ foca a sua seleção nos títulos, e então se adapta ao modelo como o título é comercializado. A biblioteca $\mathrm{H}$ não informou o motivo para escolha do modelo ilimitado.

O bloco das perguntas 29 a 37 trata dos aspectos relacionados ao modelo de seleção. Por questão de similaridade, as questões 29 e 30 foram unidas no quadro 28. Elas identificam qual é o modelo de seleção adotado pela biblioteca e porque ele foi escolhido.

Quadro 28 - Modelo de seleção

\begin{tabular}{|l|l|l|}
\hline \multicolumn{2}{|l|}{ 29. Modelo de seleção } & 30. Por que escolheu esse modelo? \\
\hline A & Título. & Única opção. \\
\hline B & Pacote. & Única opção. \\
\hline C & Pacote e título. & Única opção disponível de acordo com o vendedor. \\
\hline D & Pacote. & Única opção. \\
\hline E & Pacote. & Única opção. \\
\hline F & Pacote. & Única opção. \\
\hline G & Título. & Única opção. \\
\hline H & Pacote. & Única opção. \\
\hline I & Pacote. & Única opção. \\
\hline J & Pacote. & Única opção. \\
\hline
\end{tabular}

Fonte: Autoria própria.

Assim como na questão 26, as questões 29 e 30 mostram que as bibliotecas não têm escolha, os modelos disponíveis para aquisição são únicos. Parece que, no contexto brasileiro, o mercado de livros eletrônicos não é regido pela clientela nem pela concorrência, mas 
unicamente pela vontade dos vendedores. Isso já foi percebido pelos bibliotecários e é algo que os desagrada profundamente, como foi destacado pela biblioteca $\mathrm{C}$ : "O que mudou foi a imposição da editora na forma de compra, que a gente realmente teve que se render, por mais que isso me desagrade. E realmente me desagrada".

A biblioteca D comentou sobre uma reunião que foi feita com algumas bibliotecas de Brasília para exigir algumas condições do vendedor. As bibliotecas que queriam algo em comum se uniram, aumentando o seu poder de negociação com os vendedores.

A biblioteca não pode ser passiva nesse ponto. A gente tem que passar a exigir
o que a gente quer, e não só o que a empresa quer. Porque se deixar... pinta e
borda. Não, a biblioteca tem que exigir. Até porque estamos montando um
acervo digital. Temos que pensar em acervos digitais, em acervamento digital,
não estamos pensando em só ter acesso. Que graça tem só ter acesso? Daqui
a um ano pode cair e eu perdi todo o conteúdo? (BIBLIOTECA D)

Das dez bibliotecas, três selecionaram os livros por título (A, C e G) e em oito a seleção foi feita por pacote (B, C, D, E, F, H, I e J). Apesar de terem aparecido dois modelos de seleção diferentes, cada um dos vendedores costuma oferecer apenas uma opção, com exceção do caso da biblioteca $\mathrm{C}$.

No que concerne à seleção, é interessante observar a declaração da biblioteca $\mathrm{C}$ sobre a base ClinicalKey da Elsevier. A empresa escolhe quais títulos fazem parte da base, e apenas podem ser adquiridos individualmente aqueles livros que não estão na base. Apesar de existirem as duas formas de seleção, quem decide como cada título pode ser adquirido é o vendedor.

Para lidar com seleção de livros eletrônicos o entrevistado da biblioteca $\mathrm{C}$ disse que a biblioteca continua selecionando seus livros por título, e se ele estiver dentro de um pacote, a biblioteca compra o pacote.

Então, por exemplo, por que compramos esse pacote? Porque esse aqui é um livro fundamental. Ele continua impresso, mas teria de comprar no mínimo 11 exemplares porque ele é um livro importante que sempre foi repetido [para todas as unidades da rede]. A editora não vende esses livros (de uns 5, 3 eram importantes) individualmente. Para comprar esses eu preciso comprar o pacote. Junto com o pacote vêm coisas que não me interessam, como livros de psiquiatria, dermatologia, emergência. Não é que eles nunca tenham sido acessados. Eventualmente um paciente pode ter um problema dermatológico e então a obra é acessada. Mas não é uma obra que eu compraria. Eu teria outras formas de atender a demanda eventual de um problema dermatológico em um paciente com um artigo de periódico ou algo assim (BIBLIOTECA C).

Mesmo que a biblioteca $\mathrm{C}$ precise comprar todo um pacote apenas por causa de um título ainda vale a pena, pois se fosse comprar a versão impressa seriam necessários muitos exemplares. Mas o ideal seria que a seleção pudesse ser feita por título. 
Às vezes não há seleção alguma, nem pacotes divididos por assuntos. Ou a biblioteca compra a base completa ou não compra nada. Como foi mencionado pela biblioteca J, esse é o caso da Pearson, que vende apenas o bloco de biblioteca completo.

De acordo com Morris e Sibert (2011) os pacotes podem ser montados de acordo com vários critérios, como assunto ou disciplina, ano de publicação ou outros determinados pelo vendedor ou pela biblioteca. Nessa pesquisa a divisão por assunto era a mais comum, mas no caso da editora Fórum a divisão dos pacotes foi feita de maneira diferente. Eles dividiram os livros no que eles chamam de séries, e cada série inclui títulos diferentes que são atualizados automaticamente. Os títulos novos são incluídos nas novas séries. Então, nesse caso, a divisão parece ter sido feita pelo ano de publicação dos livros.

A pergunta “31. O vendedor oferece desconto para a compra de pacotes?" busca saber se há desconto na compra por pacote. Essa questão não se aplica às bibliotecas A e G. para as bibliotecas B, C, E, F, H e J esse desconto existe, e para as bibliotecas D e I não.

A maioria dos vendedores oferece o pacote como a única opção, então essa resposta, assim como a número 39, depende muito da percepção do entrevistado. Afinal, apenas existiria um desconto real se houvesse a opção de seleção por título. O entrevistado da biblioteca C percebeu isso: “Oferece. Apesar de não oferecer o título individual”.

A biblioteca $\mathrm{C}$ só conseguiu assinar apenas os dez periódicos da Wiley que interessavam a ela, ao invés dos 35 que pagavam, quando ameaçou cancelar todas as assinaturas. "A verdade hoje é que as bibliotecas ficam muito presas ao que a editora dita" (Biblioteca C). Apesar de esse ser um caso com periódicos, ele ilustra bem a luta que as bibliotecas precisam travar com os vendedores para adquirir apenas o que interessa a elas. Mais do que o desconto em pacotes caríssimos, muitas bibliotecas preferem a possibilidade de pagar apenas pelo que interessa a elas, selecionando os livros título a título. No mercado dos livros impressos é ilegal que um vendedor apenas te venda um livro se você também comprar outro, então porque isso é aceito no mercado de livros eletrônicos? Isto é denominado "venda casada" e é proibido legalmente pelo art. 39, inciso I, do Código de Defesa do Consumidor (BRASIL, 1990). Ainda não existem leis específicas para o mercado de livros eletrônicos, mesmo assim é importante que as leis que existem sejam interpretadas corretamente, e que se evite que os maus hábitos se tornem a regra.

$\mathrm{Na}$ biblioteca $\mathrm{B}$, que é uma biblioteca grande, todo o processo de compra é bem dividido entre os seus setores. O setor de referência justifica o porquê da assinatura e a negociação é feita pelo setor de compras. Esse modelo parece pouco funcional para a aquisição de livros eletrônicos, onde todos os detalhes da seleção estão profundamente ligados à composição do valor final do produto. 
A seleção de livros eletrônicos envolve muito mais do que apenas decidir quais títulos devem ser comprados e depois adquiri-los com quem oferecer o menor preço. Por isso, a lei de licitações (Lei 8.666/93) existente, juntamente com as cartas de exclusividade apresentadas pelas plataformas, precisam ser analisadas cuidadosamente para serem reformadas com urgência.

A biblioteca $\mathrm{F}$ relata outra situação recorrente na compra de materiais eletrônicos, que é a prática das empresas de oferecerem um desconto apenas na primeira compra ou no primeiro ano de assinatura. Depois, mesmo que a biblioteca continue comprando por pacotes, o preço aumenta, e com isso aumenta também o risco de ela não ter condições para renovar a assinatura.

Para a biblioteca J, o desconto nos pacotes da Saraiva foi relacionado com o número de acessos adquiridos. A biblioteca pegou um número maior de acessos e por isso comprou a base inteira pelo preço do menor pacote, que é de 200 livros.

A questão “32. A biblioteca podia selecionar os títulos do pacote?” busca saber se a biblioteca teve a opção de escolher quais títulos iriam compor o pacote, ou se ele foi montado pelo vendedor.

Essa questão não se aplica às bibliotecas $\mathrm{A}$ e $\mathrm{G}$, que não compraram por pacote. Fora a biblioteca $\mathrm{J}$, todas as outras (B, C, D, E, F, H e I) não puderam escolher os títulos que iam compor o pacote.

A única plataforma que permitia selecionar os títulos dos pacotes era a Saraiva e, de acordo com a biblioteca J, o preço é dado em blocos de 200 livros. Mesmo assim a biblioteca decidiu comprar a base completa, pois cada biblioteca da rede possui necessidades diferentes e a seleção seria parcial. "Para nós é melhor pegar o montante total que atende todas, sem deixar ninguém de fora" (BIBLIOTECA J).

A seleção dos títulos que vão compor um pacote é uma maneira de permitir que a biblioteca escolha quais títulos ela vai levar, ao mesmo tempo em que permite a venda em bloco, com o oferecimento de descontos quando comparado com o preço de cada título. Assim, esse parece ser um modelo bom para vendedores e compradores, pois permite que o vendedor lucre com mais livros sem tirar o poder de escolha das bibliotecas.

O quadro 29 mostra as respostas da questão 33, que busca saber se mesmo com os títulos não desejados a biblioteca julga que o valor do pacote vale a pena. 
Quadro 29 - O valor do pacote compensa os títulos não desejados?

\begin{tabular}{|c|c|c|c|}
\hline \multicolumn{4}{|c|}{ 33. O valor do pacote compensava os títulos não desejados? } \\
\hline & Sim & Não & Comentários \\
\hline A & - & - & Não se aplica. \\
\hline $\mathrm{B}$ & $\mathrm{X}$ & & "Por isso o pacote foi adquirido." \\
\hline $\mathrm{C}$ & $\mathrm{X}$ & & $\begin{array}{l}\text { "Vale a pena porque eu teria de comprar } 11 \text { exemplares. Esses têm } \\
\text { [a possibilidade de] acesso de várias pessoas ao mesmo tempo, o } \\
\text { que não acontece com o livro impresso. Apesar do preço, mesmo } \\
\text { que a compra em papel possa sair mais barata, eu não tenho esse } \\
\text { acesso imediato nem de vários usuários ao mesmo tempo". }\end{array}$ \\
\hline $\mathrm{D}$ & $\mathrm{X}$ & & $\begin{array}{l}\text { A biblioteca comprou um pacote fechado, mas avaliou os livros do } \\
\text { pacote um a um para ver quantos interessavam. }\end{array}$ \\
\hline $\mathrm{E}$ & $\mathrm{X}$ & & $\begin{array}{l}\text { "Pela quantidade de livros e pela avaliação dos pesquisadores } \\
\text { achamos que sim". }\end{array}$ \\
\hline $\mathrm{F}$ & $\mathrm{X}$ & & $\begin{array}{l}\text { "Sim, compensa muito, mesmo com muitos livros que não } \\
\text { interessam". }\end{array}$ \\
\hline $\mathrm{G}$ & - & - & Não se aplica. \\
\hline $\mathrm{H}$ & $\mathrm{X}$ & & $\begin{array}{l}\text { Vale a pena porque economizamos no processamento e temos a } \\
\text { possibilidade de ofertar o livro mais rapidamente. }\end{array}$ \\
\hline I & & $\mathrm{X}$ & O ideal seria que a seleção fosse por título. \\
\hline $\mathbf{J}$ & $\mathrm{X}$ & & $\begin{array}{l}\text { Compensa porque na verdade não tem título que não é desejado, } \\
\text { pelo motivo que fizemos a assinatura. }\end{array}$ \\
\hline
\end{tabular}

Fonte: Autoria própria.

Essa pergunta não se aplica às bibliotecas A e G, que selecionaram seus livros por título. O valor do pacote compensava os títulos não desejados para as bibliotecas B, C, D, E, F, H e J, e não compensava na opinião da biblioteca I.

Essa pergunta vai direto ao ponto, questionando o entrevistado para saber se na opinião dele a compra do pacote foi uma boa maneira de investir os recursos. Em muitas entrevistas essa pergunta já havia sido respondida junto com as anteriores, pois a justificativa da escolha por um pacote envolve a sua vantagem econômica. De acordo com Grigson (2011) uma desvantagem da compra por pacote é que a biblioteca paga por conteúdo que pode não ser utilizado, o que representa um desperdício de recursos valiosos. Para contornar esse problema, Grigson (2009 apud MORRIS; SIBERT, 2011) sugere que a biblioteca avalie o custo por uso, e não o custo por título.

A biblioteca B foi direta em sua resposta, e disse que se o valor do pacote não valesse a pena ele não teria sido adquirido. Já a biblioteca $\mathrm{D}$ foi mais detalhista ao explicar que todos os títulos do pacote foram analisados um a um e que, pelo alto valor, se mais da metade não fosse do interesse da biblioteca ele não seria adquirido. Essa é uma visão diferente da adotada pela biblioteca C, para a qual é importante que certos títulos sejam adquiridos, mesmo que isso signifique que a biblioteca precisa comprar um pacote inteiro. Isso está de acordo com a visão 
de Gregory (2011), que afirma que na compra de um pacote é comum que a biblioteca precise pagar por itens menos interessantes para ter o que ela realmente deseja. Para a biblioteca $\mathrm{C}$ a compra dos pacotes é vantajosa pois há economia quando comparada com a compra de vários exemplares impressos.

A biblioteca E levou em conta a opinião dos usuários na decisão sobre o pacote, e disse que a compra valia a pena também por causa da quantidade de livros.

A biblioteca $\mathrm{F}$ disse que o valor do pacote compensa mesmo que seja necessário pagar por títulos que não interessam, mas a maior parte dos livros do pacote interessa a eles: "Por um pequeno levantamento que fizemos de um curso, em torno de $50 \%$ dos livros do plano de ensino do curso inteiro estão na biblioteca digital. Então a grande maioria interessa" (BIBLIOTECA F).

A economia feita por não haver necessidade de processamento técnico, o que leva também a uma rápida disponibilização dos livros, foram os fatores destacados pela biblioteca H.

Para a biblioteca $\mathbf{J}$ todos os títulos valem a pena pelo motivo que ela faz a assinatura, que é exatamente para oferecer uma variedade maior de títulos aos alunos além da bibliografia básica dos cursos. A única objeção é que o entrevistado tem a impressão de que os livros eletrônicos são mais utilizados por ex-alunos e professores, e os alunos só os procuram quando esgota o número de exemplares na estante.

A biblioteca I foi a única a afirmar que o valor do pacote não compensava os títulos não desejados. Para eles, o ideal seria que essa seleção fosse feita por título. Depois de ver, nas respostas anteriores, que a seleção de pacotes era uma opção única de seleção, é intrigante que apenas uma biblioteca tenha declarado que o seu preço não vale a pena. Durante as entrevistas, muitos problemas dos modelos de aquisição foram mencionados, mas as bibliotecas foram se adaptando ao que é oferecido. Existem alguns pontos de resistência, como a biblioteca C, que se declarou insatisfeita com a imposição da editora na forma de compra, e a biblioteca $\mathrm{D}$, que junto com outras, reuniu os vendedores para reivindicar o seu direito à posse do conteúdo adquirido. Apesar disso, no final das contas, a maioria fica satisfeita com os pacotes oferecidos.

O quadro 30 traz as respostas da pergunta 34 , que busca saber se a plataforma oferece a atualização automática das edições. 
Quadro 30 - Atualização automática das edições

\begin{tabular}{|l|c|c|l|}
\hline \multicolumn{3}{|l|}{ 34. As edições são atualizadas automaticamente? } \\
\hline & Sim & Não & Comentários \\
\hline A & - & - & Não se aplica. \\
\hline B & X & & \\
\hline C & X & & \\
\hline D & X & & $\begin{array}{l}\text { São atualizadas durante o período do contrato, e a biblioteca possui } \\
\text { acesso perpétuo às edições adquiridas. }\end{array}$ \\
\hline E & - & - & Não se aplica. A biblioteca não possui assinaturas. \\
\hline F & X & & $\begin{array}{l}\text { "A base é atualizada constantemente na medida em que vão surgindo } \\
\text { títulos novos, então esse número varia. Na verdade, nós compramos } \\
\text { o acesso à plataforma. Nunca me atentei à quantidade de livros } \\
\text { eletrônicos. Ficamos muito voltados para o livro físico e a partir dele } \\
\text { é que observamos se temos o digital ou não para poder apoiar". }\end{array}$ \\
\hline G & - & - & Não se aplica. \\
\hline H & X & & $\begin{array}{l}\text { A Fórum lança produtos novos logo depois do período de renovação } \\
\text { da biblioteca, então o material comprado está sempre defasado em } \\
\text { um ano. }\end{array}$ \\
\hline I & X & & $\begin{array}{l}\text { "Conforme vão saindo as atualizações eles já modificam na base. E } \\
\text { eles fazem isso mesmo, não é só promessa". }\end{array}$ \\
\hline J & X & &
\end{tabular}

Fonte: Autoria própria.

Essa questão não se aplica às bibliotecas $\mathrm{A}, \mathrm{E}$ e $\mathrm{G}$, que não possuem assinaturas. Em todas as outras bibliotecas (B, C, D, F, H, I e J) as edições são atualizadas automaticamente.

Quando a compra é feita por assinatura, é comum que o vendedor ofereça a atualização automática dos títulos durante esse período. Mas quando a compra é feita por acesso perpétuo isso não é comum, pois a biblioteca adquire aquela edição para sempre. Outra prática comum nas assinaturas é a inserção de novos títulos na plataforma, que é o caso citado pela biblioteca F com a Pearson e com a Minha Biblioteca. Quando a biblioteca assina uma plataforma completa, não apenas os títulos que já existem são atualizados, como os novos também são adicionados, dependendo da plataforma.

Esse é um ponto interessante e que não havia sido mencionado na revisão de literatura. A inserção automática de títulos é benéfica ao agregar material sem nenhuma cobrança extra, e é um reflexo da falta de possibilidade de seleção que está muito presente na aquisição de livros eletrônicos. Para os bibliotecários, a seleção é uma parte muito importante do seu serviço, e o fato de não escolher os títulos que vão compor o seu acervo causa muito estranhamento. A nãoseleção dos livros eletrônicos é negativa quando a biblioteca é obrigada a pagar por um material que ela julga não ser interessante para ela, e também pode ser prejudicial, no caso da inserção automática, quando algum material considerado como não apropriado passa a integrar o seu acervo sem conhecimento do bibliotecário. Isso pode ser especialmente problemático nos casos 
das bibliotecas escolares e públicas onde, historicamente, alguns temas costumam causar muito furor e revolta por parte dos pais que não querem que seus filhos tenham acesso a alguns conteúdos.

A seleção dos títulos é um assunto delicado que sempre encontra muitas divergências nas bibliotecas, até mesmo dentro das equipes que cuidam dela, por isso a compra de um produto com uma seleção geral apenas de qual base é comprada, ou apenas de pacotes de assuntos, pode trazer muitas consequências inesperadas e ainda desconhecidas para a Biblioteconomia.

Entretanto, a inclusão automática dos títulos pode ser boa ao oferecer material novo e de interesse para o usuário sem a necessidade de interferência do bibliotecário ou de um complexo e demorado processo de compra. Cabe à cada biblioteca avaliar, para o seu caso, se as vantagens compensam as desvantagens.

A questão 35 procura saber se a biblioteca tem acesso às edições anteriores dos livros. As respostas para essa pergunta estão no quadro 31.

Quadro 31 - Acesso às edições anteriores

\begin{tabular}{|c|c|c|c|c|}
\hline \multicolumn{5}{|c|}{ 35. Tem acesso às edições anteriores? } \\
\hline Empresas nacionais & $\begin{array}{l}\text { Biblio- } \\
\text { teca }\end{array}$ & Sim & Não & Comentários \\
\hline \multirow[t]{3}{*}{ Fórum } & $\mathrm{D}$ & $\mathrm{X}$ & & \\
\hline & $\mathrm{H}$ & $\mathrm{X}$ & & $\begin{array}{l}\text { "Com a Fórum vai ter, porque eles deixam a primeira série } \\
\text { bem separada. A nova série de livros eletrônicos são novos } \\
\text { títulos". }\end{array}$ \\
\hline & I & $\mathrm{X}$ & & \\
\hline Livraria Cultura & $\mathrm{A}$ & & $\mathrm{X}$ & \\
\hline Livreiro & $\mathrm{G}$ & & $\mathrm{X}$ & \\
\hline Minha Biblioteca & $\mathrm{F}$ & $\mathrm{X}$ & & \\
\hline Revista dos Tribunais & $\mathrm{H}$ & & & \\
\hline Saraiva & $\mathrm{J}$ & $\mathrm{X}$ & & \\
\hline \multicolumn{5}{|l|}{$\begin{array}{l}\text { Empresas } \\
\text { estrangeiras }\end{array}$} \\
\hline CABI & $\mathrm{E}$ & & $\mathrm{X}$ & \\
\hline \multirow[t]{2}{*}{ Ebrary } & $\mathrm{B}$ & $\mathrm{X}$ & & $\begin{array}{l}\text { "Sim, mas é necessário pedir. Mas ninguém gosta de anterior, } \\
\text { todo mundo gosta de atual". }\end{array}$ \\
\hline & $\mathrm{H}$ & $\mathrm{X}$ & & $\begin{array}{l}\text { "Da Ebrary tem bastante, mas tem mais título antigo do que } \\
\text { atual". }\end{array}$ \\
\hline \multirow[t]{2}{*}{ Elsevier } & $\mathrm{C}$ & & $\mathrm{X}$ & \\
\hline & $\mathrm{E}$ & & $\mathrm{X}$ & \\
\hline McGraw-Hill & $\mathrm{C}$ & & $\mathrm{X}$ & \\
\hline \multirow[t]{2}{*}{ Pearson (EBSCO) } & $\mathrm{F}$ & $\mathrm{X}$ & & \\
\hline & $\mathrm{J}$ & $\mathrm{X}$ & & \\
\hline Safari Books & $\mathrm{H}$ & & $\mathrm{X}$ & $\begin{array}{l}\text { "Com a Safari books eu acho que não porque pra [sic] não } \\
\text { ficar muito pesado eles acabam excluindo". }\end{array}$ \\
\hline Springer & $\mathrm{E}$ & & $\mathrm{X}$ & \\
\hline V-lex & $\mathrm{J}$ & $X$ & & \\
\hline
\end{tabular}

Fonte: Autoria própria. 
As bibliotecas B, D, F, H, I e J têm acesso às edições anteriores, e as bibliotecas A, C, D, E e G não têm acesso.

Outra questão nova trazida pelos livros eletrônicos é a disponibilidade das edições anteriores de um título. Quando a biblioteca compra livros impressos, eles apenas deixam de fazer parte do acervo quando a biblioteca decide que eles devem ser descartados. Mas quando a biblioteca assina uma plataforma, pode acontecer de os livros desaparecerem sem o seu consentimento, ou de as edições anteriores nunca serem disponibilizadas. Quando os livros eletrônicos são comprados por acesso perpétuo, a continuidade depende da preservação digital dos arquivos, que pode ser feita pela biblioteca ou pelo vendedor.

Para a preservação de uma grande quantidade de materiais eletrônicos existem os dark archives, que são sistemas de acesso seguro a conteúdos (SANTANA, 2015). Eles permitem armazenar dados de maneira que eles estejam seguros, mas não sejam facilmente acessados por qualquer um (WEBOPEDIA, 2015). O acesso pode ser limitado a alguns indivíduos ou até mesmo ser completamente restrito (WEBOPEDIA, 2015). O dark archive é criado para ser um repositório à prova de falhas quando algum desastre impede o acesso aos arquivos originais (WEBOPEDIA, 2015). De acordo com Santana (2015) eles apenas podem ser acionados para uso em alguns casos: se alguma coleção não estiver mais disponível na plataforma, se o editor encerrar as atividades, para acesso pós cancelamento, se houver indisponibilidade das coleções antigas ou se houver uma falha catastrófica que torne o conteúdo do editor indisponível por mais de 90 dias. As iniciativas internacionais Portico, HathiTrust, LOCKSS e CLOCKSS e a nacional Rede Cariniana são exemplos de serviços de preservação digital.

Quando a biblioteca paga apenas pelo acesso a livros eletrônicos que ficam na plataforma do vendedor, o acesso às edições anteriores depende da plataforma. A biblioteca $\mathrm{H}$ disse que não encontra edições anteriores na Safari, e imagina que isso acontece por essa ser uma plataforma muito grande, e por isso a presença das edições anteriores poderia deixá-la muito pesada. Já a plataforma Ebrary costuma oferecer as edições anteriores dos livros, e a reclamação é ao contrário, de que ela não possui muitos títulos atuais e as edições novas demoram a ser inseridas.

Para o entrevistado da biblioteca $\mathrm{C}$, a falta de acesso às edições anteriores é um problema de preservação da memória, um problema histórico para a humanidade. Os livros têm um papel importante no relato da história. Os livros eletrônicos, assim como qualquer material nesse suporte, também são voláteis e podem desaparecer com facilidade. A longo prazo, principalmente se muitos livros forem publicados apenas em formato eletrônico, se não houver uma preservação adequada desse material nossa história pode simplesmente desaparecer. 
De acordo com a biblioteca $\mathrm{F}$ a disponibilização das edições anteriores é diferente para cada título. Os livros que sofrem muitas alterações costumam ter as edições anteriores retiradas. A biblioteca precisa negociar com o vendedor e deixar claro se ela tem interesse no acesso às edições anteriores, notadamente na área de Direito onde é importante visualizar as mudanças ocorridas ao longo do tempo. Para plataformas muito grandes essa disponibilização pode ser problemática por ocupar muito espaço nos servidores ou contribuir para que a base fique lenta. As bibliotecas devem negociar as suas necessidades com o vendedor, e esses devem ser honestos e claros sobre o que será ou não disponibilizado, informando à biblioteca antecipadamente quando algo precisar ser retirado da plataforma, ou quando novos títulos forem incluídos.

Doucette e Lewontin (2012) sugerem que quando a biblioteca precisa ter acesso às edições anteriores, talvez a melhor opção para garantir o acesso seja a compra das cópias impressas. Entretanto, caso a biblioteca prefira ter esses livros em formato eletrônico, ela pode combinar o acesso perpétuo com uma boa estratégia de preservação digital.

A pergunta “36. Os livros sofrem algum período de embargo?" procura saber se há um período de embargo para que os livros sejam incluídos na plataforma.

Quando a biblioteca compra uma plataforma, muitas vezes o acordo diz que novos títulos e novas edições serão incluídos automaticamente. Mas às vezes os livros sofrem um período de embargo, ou seja, o vendedor espera um certo período antes que eles sejam incluídos. O problema é que muitas vezes esse período não é comunicado pelo vendedor. Ao assinar uma plataforma, dificilmente a biblioteca terá como controlar a atualização de todos os títulos presentes nela. Ainda assim, às vezes, acontece de a biblioteca descobrir por acaso que algo que deveria estar ali não está.

Essa pergunta não se aplica às bibliotecas $A$ e $G$, que não possuem atualizações automáticas dos títulos. As bibliotecas B, C, D, F, H e J declararam que os livros sofrem algum período de embargo, e as bibliotecas E, I disseram que não há embargo.

A resposta da biblioteca $\mathrm{C}$ é curta mas diz muito sobre o assunto: "Não que eu saiba". Quer dizer que pode ser que ele exista, mas, se existir, não foi comunicado pelo vendedor, não está previsto no contrato e nem foi observado pela biblioteca. Mas, como não há confiança, pode ser que sim, ele exista.

Doucette e Lewontin (2012) orientam as bibliotecas a perguntarem diretamente aos fornecedores sobre os motivos das limitações na atualização. A biblioteca B questionou o Ebrary diretamente sobre isso, e a resposta foi vaga, dizendo que os livros nem sempre sofrem embargos e que isso depende do contrato firmado com a editora. Faltou dizer qual é o período 
de embargo que consta nos contratos. É conhecido que esse período de embargo existe, mas ele ainda não está claro para os compradores. A biblioteca $\mathrm{J}$ acredita que esse período existe, mesmo que não esteja previsto no contrato.

A biblioteca H compra pacotes da Ebrary, com títulos que são escolhidos por eles. Mas existem alguns títulos que fazem parte da plataforma, mas não fazem parte da coleção. Esses são títulos mais atuais que devem ser comprados separadamente pela biblioteca. Assim, devese pagar mais para ter acesso aos títulos novos. Essa é uma maneira diferente de realizar o embargo, que nesse caso é feito por título e não por edição.

A biblioteca F já percebeu que alguns títulos da editora Atlas, que faz parte do Minha Biblioteca, já estavam disponíveis em formato eletrônico para aquisição, mas ainda não haviam sido inseridos na plataforma. A biblioteca imagina que essa demora na disponibilização deve acontecer porque ou a editora ou o autor ainda não autorizaram a inclusão, mas nunca questionou isso para esclarecer essa questão com o vendedor. Nesse caso, o embargo não seria feito propositalmente pela plataforma, mas seria apenas um resultado da burocracia necessária para a disponibilização.

A biblioteca $\mathbf{J}$ passou por uma situação curiosa com a editora Saraiva. A área do direito está passando por uma transição do antigo para o novo Código de Processo Civil. O entrevistado já havia visto que esse material estava disponível na plataforma, então quando lhe foi oferecido, ele optou por não adquirir a versão impressa. Mas qual não foi a sua surpresa ao perceber que 15 dias depois o material já não estava disponível na plataforma. O entrevistado entrou em contato com a Saraiva para reclamar, pois se o material já estava disponível na plataforma não podia desaparecer, tinha que voltar para a base. O fornecedor aproveitou que o controle da base é feito por ele para manipular o seu conteúdo e tentar vender o mesmo produto duas vezes para a biblioteca, que felizmente estava atenta e percebeu o que estava acontecendo. Esse caso é similar ao relatado por Procópio (2010 apud REIS; ROZADOS, 2014), no qual o livro "1984" foi apagado de aparelhos Kindle sem o consentimento dos compradores.

Muitas bibliotecas não têm como acompanhar tudo o que é alterado nas plataformas, mas é importante que sempre que alguma situação inadequada seja percebida, isso seja comunicado imediatamente para que a biblioteca faça valer os seus direitos.

A pergunta 37 foi comentada anteriormente, logo depois da 24. O bloco das perguntas 38 a 52 traz questões sobre o meio de acesso e o uso dos livros eletrônicos. A pergunta “38. $\mathbf{O}$ acesso é oferecido pela plataforma do vendedor ou em uma plataforma própria?" procura saber em qual plataforma os livros são acessados. 
As bibliotecas D e I, nas quais o acesso é oferecido em uma plataforma própria da biblioteca, também podem acessar os livros na plataforma do vendedor pois ela estaria disponível de qualquer maneira e provavelmente já está inclusa no preço dos livros.

É interessante observar que a maioria das bibliotecas oferece o acesso apenas na plataforma do vendedor (B, C, E, F, H e J). Isso traz uma certa comodidade para a biblioteca, que não precisa se preocupar com questões de disponibilização do acesso ou preservação digital. Quando há algum problema no acesso basta entrar em contato com o vendedor.

Cada modelo de comercialização do livro eletrônico tem as suas vantagens e desvantagens. Quando o acesso é reponsabilidade do vendedor a biblioteca perde o controle sobre os títulos disponíveis na base. Quando a plataforma é muito grande não há como a biblioteca verificar se todos os títulos adquiridos estão disponíveis. A vantagem nesse caso é que da mesma maneira que os títulos podem ser retirados, eles podem ser atualizados automaticamente sem interferência da biblioteca. Quando o acesso está disponível apenas na plataforma da biblioteca ela deve se preocupar com o funcionamento correto dessa plataforma e com a preservação digital desses arquivos, que não é uma tarefa fácil principalmente se a quantidade de livros adquiridos for grande.

Nas bibliotecas A e G o acesso aos livros é atrelado aos aparelhos nos quais os livros foram baixados, e só é possível ler esses livros neles. Sendo assim, o acesso dos usuários não é feito por uma plataforma já que está diretamente ligado ao suporte. Essas duas bibliotecas compraram de distribuidores e, de acordo com o que diz Grigson (2011), quando a compra é feita com distribuidores o acesso aos livros é feito pela plataforma da editora. Para essas bibliotecas, a plataforma da editora foi utilizada apenas para o download do livro para os aparelhos.

A biblioteca $\mathrm{H}$ destacou que a pesquisa das diferentes plataformas não é unificada. Esse é um problema para as bibliotecas nas quais o acesso é feito pela plataforma do vendedor, que, nessa pesquisa, foram oito, que são todas menos aquelas onde o acesso é ligado ao suporte. Mesmo as que possuem plataforma própria também tem o aceso pelo vendedor. Esse problema também afeta as bibliotecas que assinam uma plataforma única, pois mesmo nesse caso a pesquisa do catálogo online da biblioteca fica separada da pesquisa da plataforma.

As bibliotecas podem utilizar um serviço de descoberta, como mencionado na questão 16, para unificar a busca. Ainda assim, o usuário terá que acessar a interface de cada plataforma para ter acesso aos livros. Outra opção para unir tudo seria se a biblioteca comprasse apenas livros de acesso perpétuo que fossem disponibilizados por ela numa plataforma própria 
integrada com o catálogo. Mas, dada a realidade dessa pesquisa, onde apenas duas bibliotecas possuem plataformas próprias, essa opção parece estar bem distante.

O quadro 32 traz as respostas da questão 52, que busca saber se é possível integrar os livros eletrônicos ao catálogo da biblioteca.

Quadro 32 - Integração dos livros eletrônicos com o catálogo

\begin{tabular}{|l|c|c|l|l|}
\hline \multicolumn{5}{|c|}{ 52. É possível integrar os livros ao catálogo da biblioteca? } \\
\hline A & X X & Não & $\begin{array}{l}\text { Comentários } \\
\text { "Sim, estão todos no Sophia e é feito um link dizendo que o livro está } \\
\text { disponível para leitura no Kobo." }\end{array}$ \\
\hline B & X & & $\begin{array}{l}\text { Sim, eles são integrados. Temos um metabuscador chamado SUMMON, } \\
\text { que é a pesquisa integrada, em que eles estão disponibilizados lá. Ao fazer } \\
\text { a pesquisa é possível ver que ele está dentro da pesquisa integrada. }\end{array}$ \\
\hline C & X & X & $\begin{array}{l}\text { Apenas os livros mais importantes foram inseridos no catálogo. } \\
\text { "Se temos o livro apenas em formato eletrônico ele também é catalogado". }\end{array}$ \\
\hline E & X & X & & $\begin{array}{l}\text { Já estão integrados. Os metadados foram enviados pela editora e o pessoal } \\
\text { responsável pelo sistema inseriu. }\end{array}$ \\
\hline F & X & & $\begin{array}{l}\text { Os registros estão no catálogo, que indica em qual base está o livro, mas não } \\
\text { tem links. }\end{array}$ \\
\hline G & & X & $\begin{array}{l}\text { Não. Eles não são parte do acervo e não podem ser emprestados. É uma } \\
\text { aquisição feita para o acervo particular e permanente da área. }\end{array}$ \\
\hline H & X & & $\begin{array}{l}\text { É possível integrar o Ebrary ao software de biblioteca, mas isso não foi feito } \\
\text { por falta de pessoal. }\end{array}$ \\
\hline I & $\mathrm{X}$ & & Os links podem ser inseridos manualmente no software. \\
\hline J & & X & "Não, fica tudo separado". \\
\hline
\end{tabular}

Fonte: Autoria própria.

Ao responder a questão 38, sobre a plataforma de acesso, muitas bibliotecas mencionaram a integração do catálogo. Essa integração não resolve o problema da utilização de interfaces distintas para o acesso, mas, resolve o problema da descoberta, permitindo que os usuários saibam que o livro está disponível para a sua biblioteca, mesmo que o acesso seja em outro lugar.

A integração dos livros eletrônicos com o catálogo é facilitada quando o vendedor envia os registros MARC para a biblioteca, mas isso não acontece sempre. Além disso, com as constantes mudanças de títulos nas plataformas, ou por causa da grande quantidade de títulos, algumas bibliotecas preferem não fazer essa integração.

Nas bibliotecas A e D a integração com o catálogo já foi feita, e inclui um link que informa onde o livro está disponível para leitura. Nas bibliotecas G e J não é possível integrar os livros ao catálogo.

Na biblioteca $\mathrm{E}$ os metadados foram enviados pela editora e inseridos pelos responsáveis pelo sistema. Mas o entrevistado destaca que: "quando o usuário entra o acesso é pela base da editora". A biblioteca F também recebeu os registros MARC, e a partir do catálogo é possível saber em qual plataforma o livro se encontra, mas não há um link direto para cada título. 
$\mathrm{Na}$ biblioteca $\mathrm{C}$ apenas os livros mais importantes foram inseridos no catálogo, mas o acesso a todos os livros é feito pela plataforma do vendedor. Se o livro não estiver no catálogo da biblioteca o usuário precisa pesquisar em cada uma das duas plataformas de livros eletrônicos. Assim, para realizar uma pesquisa completa de livros é necessário pesquisar em três plataformas diferentes, o que faz os usuários perderem tempo.

$\mathrm{Na}$ biblioteca $\mathrm{H}$ a integração com o Ebrary não foi feita por falta de pessoal para fazer esse serviço, e na biblioteca I a integração poderia ser feita manualmente. A biblioteca $\mathrm{H}$ mencionou em sua entrevista que uma vantagem dos livros eletrônicos era a rapidez na sua disponibilização, o que inclui a falta de necessidade de processamento. Quando compram livros eletrônicos as bibliotecas pensam na sua rapidez e na possibilidade de oferecer um acervo imenso, que elas jamais poderiam oferecer se fosse impresso, aos seus usuários. A integração pode consumir o tempo dos funcionários da biblioteca, que às vezes já estão em número reduzido, e por isso acaba sendo relegada.

Apenas a biblioteca B disse que utiliza um serviço de descoberta, que no caso é o Summon, para integração. Apesar de úteis, os serviços de descoberta são caros, o que inviabiliza a sua aquisição para a maioria das bibliotecas, principalmente as menores e aquelas que possuem poucos recursos financeiros.

A pergunta “39. É necessário pagar uma taxa anual de acesso à plataforma? Em caso afirmativo, qual o período mínimo/máximo durante o qual a taxa deverá ser paga?" procura saber se, além do valor dos livros, a biblioteca precisa pagar alguma taxa pelo acesso à plataforma. Doucette e Lewontin (2012) mencionam que é necessário pagar uma taxa para usar a plataforma online do vendedor.

A resposta para essa pergunta depende da percepção do comprador. Se a compra foi por assinatura, sempre que ela é renovada o valor de acesso à plataforma já está embutido no preço, mesmo que não seja discriminado, que não conste separadamente. As bibliotecas B, D e F perceberam a contradição na pergunta, e disseram que o valor da plataforma está embutido no valor da assinatura.

As bibliotecas C, E, H, I e J disseram que não é necessário pagar nenhuma taxa a mais, e essa pergunta não se aplica às bibliotecas A e G.

Se a biblioteca $\mathrm{C}$, no caso da Elsevier, não tiver uma assinatura, ela precisa pagar uma taxa para acesso aos livros adquiridos de forma perpétua. Isso é uma contradição desse modelo, já que em teoria a biblioteca pagou para ter acesso ao livro para sempre, mas se não pagar também pelo acesso à plataforma não terá acesso aos livros. Por isso o ponto de vista da biblioteca $\mathrm{D}$ de compra do conteúdo é tão importante, exigindo que a biblioteca possua a cópia 
dos livros. Já que a biblioteca $\mathrm{C}$, a princípio, comprou o conteúdo, mas ele continua apenas nas mãos do vendedor.

As bibliotecas $\mathrm{C}, \mathrm{H}$ e $\mathrm{J}$ declararam não pagar um valor extra pelo acesso à plataforma. Há uma contradição nisso, pois na questão 55 elas declararam que o valor da plataforma varia de acordo com o número de acessos. A taxa para acesso à plataforma existe, e é tão importante que é explicitamente incluída na composição do preço, juntamente à seleção dos títulos ou pacotes.

A pergunta 40, do quadro 33, procura saber quais programas devem ser utilizados pelos usuários para que eles possam ter acesso ao livro eletrônico.

Quadro 33 - Programas para ler os livros eletrônicos

\begin{tabular}{|l|l|}
\hline $\begin{array}{l}\text { 40. É necessário o uso de algum programa (software) em especial para acesso aos } \\
\text { livros? Qual? }\end{array}$ \\
\hline A & Aplicativo Kobo. \\
\hline B & $\begin{array}{l}\text { Adobe Reader (para laptop e desktop) e Bluefire (para smartphones e tablets, iOS ou } \\
\text { Android) }\end{array}$ \\
\hline C & Não. \\
\hline D & Não. O PDF é normal, possui apenas uma marca d'água. \\
\hline E & "Não, é um PDF normal. É só entrar e baixar, sem bloqueios". \\
\hline F & $\begin{array}{l}\text { "Se for baixar um capítulo é necessário usar um aplicativo para poder utilizar o que } \\
\text { baixou. Tanto no Minha Biblioteca quanto na Pearson". }\end{array}$ \\
\hline G & $\begin{array}{l}\text { Eu acredito que sim porque o livreiro acaba comprando de fornecedores diferentes } \\
\text { então cada um, dependendo do lugar onde se compra, tem um editor diferente. Por } \\
\text { exemplo na realidade particular, se eu vou comprar um livro na Cultura tem um editor } \\
\text { próprio que é o Kobo, o da Saraiva tem o deles. }\end{array}$ \\
\hline H & Na Ebrary, só quando faz o download. \\
\hline I & Só precisa ter acesso à Internet e uns plug-ins, para o acesso online. \\
\hline J & Não tem plataforma, não precisa baixar um programa, é tudo online. \\
\hline
\end{tabular}

Fonte: Autoria própria.

As bibliotecas A, B, F, G e H informaram que é necessário utilizar algum programa para ler os livros. Dessas, apenas as bibliotecas A e B informaram os nomes dos programas, e no caso da biblioteca B essa resposta foi dada posteriormente. Nas bibliotecas C, D, E, I e J não é necessário utilizar nenhum programa específico para ler os livros. As bibliotecas I e J destacaram que o acesso é apenas online.

Essa pergunta foi crucial na observação de que os bibliotecários não utilizam os livros como usuários. Na maioria das entrevistas eles tiveram dificuldade para descrever como é o acesso, se é necessário utilizar algum programa para ler os livros quando é feito o download e qual é o programa que deve ser utilizado. Poucos souberam dizer o nome dos programas sozinhos ou sem consultarem a plataforma. Isso mostra como o acesso aos livros é complexo, principalmente por ser diferente para cada plataforma. 
Os vendedores costumam exigir a utilização de programas específicos para fazer o controle dos direitos de autor (DRM) quando o download dos livros é permitido. Muitos sequer permitem que os livros sejam abertos fora de suas plataformas, ou permitem que seja feito o download de apenas algumas partes ou capítulos dos livros.

\begin{abstract}
Algumas bases já estão oferecendo isso. Por exemplo a Revista dos Tribunais tem um formato próprio deles chamado Proview. Eles querem que seja instalado em todas as máquinas do tribunal. Já nós estamos batendo o pé que a gente quer em pdf. Então ainda estamos em uma certa negociação. Mas por isso, como todos os computadores do tribunal vão ter leitores de pdf, porque é que eu não vou colocar pdf? Vou fazer todo mundo instalar o software? Eles querem mudar a nossa cultura (BIBLIOTECA D).
\end{abstract}

O quadro 34 traz as respostas da pergunta 41, que busca saber para quem os livros eletrônicos adquiridos estão disponíveis.

Quadro 34 - Acesso ao livro eletrônico

\begin{tabular}{|l|l|}
\hline 41. Quem tem acesso ao livro eletrônico? \\
\hline A & $\begin{array}{l}\text { "Todos os funcionários da empresa, desde que registrados na biblioteca." Os terceirizados e } \\
\text { estagiários não têm acesso aos livros eletrônicos. }\end{array}$ \\
\hline B & $\begin{array}{l}\text { "Toda a comunidade universitária e a comunidade externa quando está dentro da biblioteca. } \\
\text { Porque dentro da biblioteca o IP é liberado para todos. Se um estudante de fora entra aqui no } \\
\text { nosso site na base de dados da Ebrary ele pode baixar e ler o livro. Isso não trouxe problemas } \\
\text { com o vendedor pois no momento da assinatura foram fornecidos os números de IP, que } \\
\text { englobam toda a biblioteca". }\end{array}$ \\
\hline C & $\begin{array}{l}\text { Todos os usuários da instituição. O acesso é institucional e local, as pessoas não têm acesso } \\
\text { de casa. Qualquer um que esteja dentro da instituição e abra a página da biblioteca tem acesso. } \\
\text { Por coisas do pessoal da informática, para alguns usuários a página da biblioteca não aparece. } \\
\text { Isso é variável de acordo com o perfil do usuário. Alguns não têm acesso à biblioteca e outros } \\
\text { nem ao computador. }\end{array}$ \\
\hline D & Todos os funcionários. \\
\hline E & Qualquer um na rede pode baixar os livros, não precisa de senha. \\
\hline F & Alunos, professores e funcionários. \\
\hline G & $\begin{array}{l}\text { Os tablets ficam sob responsabilidade do gestor do departamento ou da divisão, então todos } \\
\text { os subordinados dele têm acesso ao tablet. Os terceirizados e menores aprendizes não têm } \\
\text { acesso, só os funcionários. }\end{array}$ \\
\hline H & Apenas os funcionários, e na Safari apenas os funcionários cadastrados. \\
\hline I & Apenas os funcionários. \\
\hline J & Todo o corpo docente e discente da instituição, incluindo os ex-alunos. \\
\hline
\end{tabular}

Fonte: Autoria própria.

O acesso aos livros eletrônicos em oito (A, C, D, F, G, H, I e J) das dez bibliotecas está disponível apenas para os usuários internos, que são aqueles funcionários do órgão ao qual a biblioteca pertence. Como costuma ser política das bibliotecas, os terceirizados e estagiários não têm acesso ao acervo, e menos ainda os usuários externos. Em muitas bibliotecas, mesmo que os usuários externos não possam levar emprestados os livros do acervo físico, eles podem pelo menos consultá-los dentro da biblioteca. Isso é o que permite o trabalho de pesquisadores que não pertencem à instituição, mas que buscam uma informação especializada e de qualidade. 
Nessa pesquisa, apenas nas bibliotecas B e E os usuários externos tem acesso aos livros eletrônicos dentro do espaço físico da biblioteca. O acesso aos livros eletrônicos, ao contrário do que se pensa, pode ser mais limitado do que o livro físico para os usuários externos. $\mathrm{O}$ acesso ao livro eletrônico não é democrático.

Quando se fala em livros eletrônicos, muitos pensam que, devido à sua natureza, ele pode ser livremente copiado e distribuído. A intenção das bibliotecas não é quebrar as leis e ferir o direito autoral. Mas as regras do meio de acesso dos livros eletrônicos podem se mostrar muito prejudiciais a longo prazo, na medida em que esses livros, na maneira como têm sido apresentados, são excludentes, e não cumprem o seu papel social. Os livros eletrônicos comprados pelas bibliotecas apenas estão disponíveis para o público para o qual eles foram comprados, e não podem ser doados ou revendidos. Isso também se aplica aos livros eletrônicos comprados por indivíduos. Esse é um cenário ideal para quem vende os livros, que consegue cobrar não pelas cópias, mas pelo uso que será feito deles. Esses livros eletrônicos não poderão ser repassados a bibliotecas comunitárias, ou a outras ações sociais que sobrevivem apenas de doações, e não chegarão às mãos de pessoas carentes, que poderiam encontrar neles uma possibilidade de crescimento e mudança de vida. Da maneira como esses livros são comercializados hoje, eles contribuem para a manutenção da exclusão social.

Por serem muito similares, as respostas das perguntas 42 e 43 foram unidas e podem ser vistas no quadro 35. Elas procuram saber se o acesso aos livros é apenas online ou se é possível fazer o download.

Quadro 35 - Forma de acesso aos livros eletrônicos

\begin{tabular}{|l|l|c|c|l|}
\hline 42. O acesso é online ou por download? \\
\hline \multirow{2}{*}{ Empresas nacionais } & $\begin{array}{l}\text { Biblio- } \\
\text { teca }\end{array}$ & $\begin{array}{l}\text { On- } \\
\text { line }\end{array}$ & $\begin{array}{l}\text { Downl } \\
\text { oad }\end{array}$ & Comentários \\
\cline { 2 - 5 } & $\mathrm{D}$ & $\mathrm{X}$ & $\mathrm{X}$ & \\
\cline { 2 - 5 } & $\mathrm{H}$ & $\mathrm{X}$ & & \\
\hline Livraria Cultura & $\mathrm{A}$ & $\mathrm{X}$ & & Pode baixar no máximo um capítulo. \\
\hline Livreiro & $\mathrm{G}$ & & $\mathrm{X}$ & \\
\hline Minha Biblioteca & $\mathrm{F}$ & $\mathrm{X}$ & & Pode baixar apenas algumas páginas. \\
\hline Revista dos Tribunais & $\mathrm{H}$ & $\mathrm{X}$ & & \\
\hline Saraiva & $\mathrm{J}$ & $\mathrm{X}$ & & \\
\hline & & & & \\
\hline Empresas estrangeiras & & & & \\
\hline CABI & $\mathrm{E}$ & $\mathrm{X}$ & $\mathrm{X}$ & \\
\hline \multirow{2}{*}{ Ebrary } & $\mathrm{B}$ & $\mathrm{X}$ & $\mathrm{X}$ & \\
\hline & $\mathrm{H}$ & $\mathrm{X}$ & $\mathrm{X}$ & \\
\hline \multirow{2}{*}{ Elsevier } & $\mathrm{C}$ & $\mathrm{X}$ & & É possível baixar os capítulos separadamente sem um limite, mas é \\
& & necessário fazer um cadastro, o download não é anônimo. \\
\hline & $\mathrm{E}$ & $\mathrm{X}$ & $\mathrm{X}$ & \\
\hline McGraw-Hill & $\mathrm{C}$ & $\mathrm{X}$ & & \\
\hline \multirow{2}{*}{ Pearson (EBSCO) } & $\mathrm{F}$ & $\mathrm{X}$ & & \\
\hline & $\mathrm{J}$ & $\mathrm{X}$ & & \\
\hline Safari Books & $\mathrm{H}$ & $\mathrm{X}$ & $\mathrm{X}$ & \\
\hline Springer & $\mathrm{E}$ & $\mathrm{X}$ & $\mathrm{X}$ & \\
\hline V-lex & $\mathrm{J}$ & $\mathrm{X}$ & & \\
\hline
\end{tabular}

Fonte: Autoria própria. 
Essa é mais uma pergunta onde os resultados dependem da interpretação do entrevistado. Em muitos casos, mesmo quando o download dos livros é permitido, ele apenas pode ser feito por capítulos. A maior parte dos acessos é online. Essa é a maneira das empresas de tentar evitar a cópia ilegal dos livros. Poucas empresas adotaram o empréstimo digital, no qual o prazo de devolução é controlado por DRM ou outro sistema similar.

Nas bibliotecas A e G, onde foi comprado o acesso perpétuo aos livros, o acesso online não está disponível. Nas bibliotecas B, D, E e H os usuários possuem duas opções, pois o acesso pode ser tanto online como por download.

Nas bibliotecas C, F, H, I e J o acesso é apenas online. Nas bibliotecas F e I é possível fazer o download de apenas um capítulo ou de algumas páginas. A biblioteca $\mathrm{C}$ não tem um limite para download dos capítulos, mas os usuários devem fazer um cadastro.

A vantagem do acesso online é que ele pode permitir que haja um acesso remoto aos livros, destacando uma das grandes vantagens do livro eletrônico, pois para pegar um livro emprestado o usuário não precisaria estar perto da biblioteca. Ao mesmo tempo, quando o acesso é apenas online, nos lugares onde o acesso à Internet é intermitente e de má qualidade, a leitura pode ser prejudicada. Mas, de acordo com o entrevistado da biblioteca $\mathrm{F}$, quando o acesso é online o livro fica armazenado na memória temporária do computador. Então, mesmo que a Internet caia é possível prosseguir com a leitura. O ideal é que sejam oferecidos ambos os tipos de acesso: online e off-line. Ainda de acordo com a biblioteca F, os capítulos são baixados em um arquivo PDF com bloqueios, que apenas pode ser lido em um programa específico.

A pergunta 44, do quadro 36, busca saber se há um período de empréstimo dos livros quando o seu download é permitido, e qual é esse período.

\section{Quadro 36 - Período de empréstimo}

\begin{tabular}{|l|l|}
\hline \multicolumn{2}{|l|}{ 44. Qual é o período de empréstimo? É possível renovar? } \\
\hline A & $\begin{array}{l}\text { "O aparelho é emprestado por 10 dias e pode renovar. No momento do empréstimo deve } \\
\text { assinar um termo de responsabilidade. Se algo acontece com o aparelho o usuário deve pagar } \\
\text { em dinheiro ou o valor deve ser descontado na sua folha de pagamento". }\end{array}$ \\
\hline B & $\begin{array}{l}\text { Se a pessoa salvou no computador dela fica para o resto da vida. [Existe um período de } \\
\text { empréstimo de 14 dias]. }\end{array}$ \\
\hline C & $\begin{array}{l}\text { Não tem período pois não é possível baixar o livro completo, e os capítulos baixados não } \\
\text { expiram. }\end{array}$ \\
\hline D & Não tem período, não tem bloqueios. \\
\hline E & Não tem período, não tem bloqueios. \\
\hline F & Não tem período de empréstimo porque o acesso é online. \\
\hline G & Não tem período de empréstimo, é controlado pelo gestor do setor. \\
\hline H & 15 dias, para Safari e Ebrary. Sim, pode renovar. \\
\hline I & Não se aplica. \\
\hline J & Não tem empréstimo. \\
\hline
\end{tabular}

Fonte: Autoria própria. 
Reafirmando as conclusões das perguntas 42 e 43, aqui é possível verificar que apenas nas bibliotecas $\mathrm{B}$ e $\mathrm{H}$ os vendedores utilizam o DRM para realizar o empréstimo dos livros eletrônicos por um período determinado. Na biblioteca B o entrevistado informou que não há período de empréstimo, mas essa função é oferecida pela Ebrary e os programas necessários para leitura constam na pergunta 40 .

Nas bibliotecas A e G é feito o empréstimo dos aparelhos, que são um e-reader e um tablet, respectivamente. $\mathrm{Na}$ biblioteca A o empréstimo do aparelho é controlado por ela, tem um período de dez dias e permite a renovação. A biblioteca $\mathrm{G}$ cuida apenas da compra dos livros, e o empréstimo do tablet é controlado pelo setor da instituição que é responsável pelo aparelho.

Nas bibliotecas C, F, I e J não há um período de empréstimo pois o acesso é feito apenas online. $\mathrm{E}$ a biblioteca $\mathrm{C}$ acrescentou ainda que os capítulos que são baixados não possuem bloqueios e nem período de expiração, ficam permanentemente com o usuário.

Nas bibliotecas D e E o usuário pode baixar o livro completo, não existe um período de empréstimo e o arquivo não possui nenhum bloqueio. Nesse caso, o uso do livro eletrônico é mais simples, pois exige apenas um programa que seja compatível com o seu formato de arquivo. O usuário pode ficar à vontade para ler o livro onde (tablet, smartphone, notebook $\mathrm{e}$ e-reader) e quando bem entender, sem necessidade de acesso à Internet e sem interferência do vendedor. Entretanto, isso também facilita a pirataria dos livros, e nesse ponto a biblioteca D destaca a responsabilidade do usuário, que deve saber da sua responsabilidade como cidadão.

A pergunta 45, do quadro 37, busca identificar como os usuários podem acessar os livros localmente, dentro da instituição ou da área da biblioteca.

Quadro 37 - Formas de acesso local aos livros

\begin{tabular}{|l|l|}
\hline \multicolumn{2}{|l|}{ 45. Quais as formas de acesso local aos livros? } \\
\hline A & Pelo e-reader ou aparelho próprio com login e senha únicos para toda a biblioteca. \\
\hline B & Por IP. \\
\hline C & $\begin{array}{l}\text { Qualquer um que esteja dentro da instituição e abra a página da biblioteca tem acesso. } \\
\text { Por coisas do pessoal da informática, para alguns usuários a página da biblioteca não } \\
\text { aparece. Isso é variável de acordo com o perfil do usuário. }\end{array}$ \\
\hline D & Por IP. \\
\hline E & Por IP. \\
\hline F & Login e senha. \\
\hline G & Pelo tablet. \\
\hline H & $\begin{array}{l}\text { Fórum e RT - acesso por IP } \\
\text { Ebrary - acesso por IP - é mais caro pois não controla o número de usuários. } \\
\text { Safari - Por licenças - Mais barato pois diz exatamente quantos podem acessar. }\end{array}$ \\
\hline I & Por IP. \\
\hline J & Pela área do aluno. \\
\hline
\end{tabular}

Fonte: Autoria própria. 
Nas bibliotecas A e G o acesso aos livros é feito apenas nos aparelhos autorizados pelas bibliotecas. Nas bibliotecas B, C, D, E, H e I o acesso local é feito por IP. Isso significa que qualquer um com acesso à Internet dentro da instituição também terá acesso aos livros.

Quando comparamos essa reposta com a da questão 41 aparecem algumas divergências, por exemplo nas bibliotecas $\mathrm{D}, \mathrm{H}$ e I que haviam afirmado que o acesso aos livros era restrito aos servidores. Se o acesso é por IP, ele só será restrito aos servidores se apenas eles tiverem acesso à Internet nos endereços de IP autorizados para acesso aos livros dentro da instituição. Caso contrário, esse acesso é um pouco mais amplo que o informado.

Nas bibliotecas F e J o acesso é bem restrito e controlado, pois depende de login e senha. Nesse caso, é possível controlar o que cada usuário faz na base, as suas pesquisas, quais livros foram abertos e os downloads realizados.

A pergunta 46, do quadro 38, busca saber de qual maneira os usuários podem acessar os livros remotamente.

Quadro 38 - Formas de acesso remoto aos livros

\begin{tabular}{|c|c|}
\hline \multicolumn{2}{|r|}{$\begin{array}{l}\text { 46. Quais as formas de acesso remoto aos livros (autenticação de IP, usuário e senha, servidor } \\
\text { proxy, URL de referência)? }\end{array}$} \\
\hline A & Pelo e-reader ou aparelho próprio com login e senha únicos para toda a biblioteca. \\
\hline $\mathrm{B}$ & Identificação de IP. \\
\hline $\mathrm{C}$ & Não tem acesso remoto. \\
\hline $\mathrm{D}$ & Pela Intranet. \\
\hline $\mathrm{E}$ & $\begin{array}{l}\text { Tem acesso remoto por login e senha, os pesquisadores podem entrar de casa na Intranet e } \\
\text { tem acesso por aí. }\end{array}$ \\
\hline $\mathrm{F}$ & Login e senha. \\
\hline G & Não há acesso remoto. \\
\hline $\mathrm{H}$ & Login e senha, pelo portal do órgão. Mas o primeiro download deve ser feito lá. \\
\hline I & Não possui acesso remoto. \\
\hline $\mathrm{J}$ & Usuário e senha, pela área do aluno. \\
\hline
\end{tabular}

Fonte: Autoria própria.

Enquanto o acesso local normalmente é por IP, o acesso remoto precisa ser mais seguro, porque de outra maneira qualquer um com acesso à Internet teria acesso aos livros eletrônicos comprados pelas bibliotecas. Nas bibliotecas D, E, F, H e J o acesso remoto é feito por login e senha, muitas vezes pela Intranet da instituição ou pela área do aluno. Uma vantagem do acesso realizado diretamente pela Intranet é que o usuário não precisa ter um login para cada plataforma, facilitando o seu acesso.

Um detalhe interessante foi informado pela biblioteca $\mathrm{H}$, onde o acesso remoto exige também que o primeiro download seja realizado presencialmente. Aparentemente, essa é uma maneira de verificar se aquele login e senha são autênticos e pertencem a alguém que efetivamente trabalha nesse órgão. 
A biblioteca B é a única que utiliza a identificação de IP para acesso remoto aos livros eletrônicos. A identificação de IP é complexa e exige que o usuário faça um procedimento complicado, que pode fazer com que ele desista do acesso remoto. Em alguns sistemas, como, por exemplo, no Portal da Capes, é possível utilizar o proxy para que o browser simule o acesso como se ele estivesse ligado a um IP autorizado.

As bibliotecas A, C, G e I não oferecem acesso remoto aos livros eletrônicos. Esse é um número alarmante ao se levar em conta que o acesso remoto é uma das grandes vantagens dos livros eletrônicos. Nessas bibliotecas os livros eletrônicos continuam presos ao espaço físico da biblioteca.

A pergunta 47, do quadro 39, procura saber com quais dispositivos os livros eletrônicos são compatíveis. Isso afeta a interação dos usuários com os livros, já que cada aparelho possui as suas funcionalidades particulares.

Quadro 39 - Dispositivos para leitura dos livros eletrônicos

\begin{tabular}{|c|c|}
\hline \multicolumn{2}{|r|}{$\begin{array}{l}\text { 47. Os livros podem ser lidos em e-readers e outros dispositivos móveis? Em caso } \\
\text { afirmativo, quais dispositivos são compatíveis? }\end{array}$} \\
\hline A & Sim, no e-reader da biblioteca e nos dispositivos onde foi feito o login. \\
\hline $\mathrm{B}$ & Sim. Dispositivos com acesso à Internet: smartphones, tablets, laptops e desktops. \\
\hline $\mathrm{C}$ & $\begin{array}{l}\text { Não, eles apenas podem ser lidos nos computadores. Mas essa é uma limitação } \\
\text { institucional, não é do produto. O produto até oferece, mas o órgão institucionalmente } \\
\text { prefere que não. }\end{array}$ \\
\hline $\mathrm{D}$ & Sim. Os livros podem ser lidos em qualquer dispositivo com suporte ao formato PDF. \\
\hline $\mathrm{E}$ & Pode ler sem problema. \\
\hline $\mathrm{F}$ & É multiplataforma. Pode ser acessado no computador, celular ou tablet. \\
\hline $\mathrm{G}$ & Não se aplica. \\
\hline $\mathrm{H}$ & Sim. \\
\hline I & Não soube responder. \\
\hline $\mathrm{J}$ & $\begin{array}{l}\text { É possível ler em qualquer dispositivo com acesso à Internet. Por exemplo: e-reader } \\
\text { (Kobo), tablet e iPad. }\end{array}$ \\
\hline
\end{tabular}

Fonte: Autoria própria.

Nas bibliotecas B, D, E, F, H e J os usuários têm liberdade para escolher onde querem ler os livros. De acordo com as bibliotecas B e J o único pré-requisito é que o dispositivo tenha acesso à Internet, e para a biblioteca $\mathrm{D}$ é necessário ter suporte ao formato PDF.

Na biblioteca $\mathrm{G}$ a leitura pode ser feita apenas nos tablets. E na biblioteca A, além do e-reader da biblioteca, ela pode ser feita em alguns dispositivos que foram cadastrados com o login da biblioteca, mas não há possibilidade de trocar de dispositivo.

A biblioteca $\mathrm{C}$ disse que o vendedor até oferece outras opções de dispositivos, mas a biblioteca preferiu que o acesso fosse restrito aos computadores da instituição. Isso demonstra que a biblioteca $\mathrm{C}$ adota uma postura oposta à da biblioteca $\mathrm{D}$. Enquanto a biblioteca $\mathrm{D}$ deixa 
os livros livres e coloca o bom uso como uma decisão moral dos usuários, a biblioteca $\mathrm{C}$ prefere restringir o uso antecipadamente, provavelmente para prevenir o seu mau uso.

Esse é um dos poucos aspectos relativos aos livros eletrônicos que são de livre decisão da biblioteca, e em duas situações elas decidiram ir por lados diferentes. Cada instituição possui as suas políticas e o mais importante é que todas ajam de acordo com a lei. Os usuários, como em todos os outros aspectos da compra dos livros eletrônicos, ficam condicionados às decisões da biblioteca. Se a biblioteca decidir que o acesso será feito em um suporte único, o usuário não terá outra opção.

A pergunta 48 , do quadro 40 , busca saber se a interface da plataforma já foi traduzida para o português.

Quadro 40 - A interface tem opção de navegação em português?

\begin{tabular}{|l|l|l|l|l|}
\hline 48. A interface tem opção de navegação em português? \\
\hline $\begin{array}{l}\text { Empresas } \\
\text { nacionais }\end{array}$ & $\begin{array}{l}\text { Biblio- } \\
\text { teca }\end{array}$ & Sim & Não & Comentários \\
\hline \multirow{2}{*}{ Fórum } & $\mathrm{D}$ & $\mathrm{X}$ & & \\
\hline & $\mathrm{H}$ & $\mathrm{X}$ & & \\
\hline & $\mathrm{I}$ & $\mathrm{X}$ & & \\
\hline Livraria Cultura & $\mathrm{A}$ & $\mathrm{X}$ & & \\
\hline Livreiro & $\mathrm{G}$ & & & Não se aplica. \\
\hline Minha Biblioteca & $\mathrm{F}$ & $\mathrm{X}$ & & \\
\hline $\begin{array}{l}\text { Revista dos } \\
\text { Tribunais }\end{array}$ & $\mathrm{H}$ & $\mathrm{X}$ & & \\
\hline Saraiva & $\mathrm{J}$ & $\mathrm{X}$ & & \\
\hline & & & & \\
\hline \multirow{2}{*}{$\begin{array}{l}\text { Empresas } \\
\text { estrangeiras }\end{array}$} & & & & \\
\hline CABI & $\mathrm{E}$ & & $\mathrm{X}$ & \\
\hline Ebrary & $\mathrm{B}$ & & $\mathrm{X}$ & \\
\hline & $\mathrm{H}$ & $\mathrm{X}$ & & $\begin{array}{l}\text { A busca está em português, mas o resto não, é } \\
\text { misturado. }\end{array}$ \\
\hline Elsevier & $\mathrm{C}$ & & $\mathrm{X}$ & \\
\hline & $\mathrm{E}$ & & $\mathrm{X}$ & \\
\hline McGraw-Hill & $\mathrm{C}$ & & $\mathrm{X}$ & \\
\hline Pearson (EBSCO) & $\mathrm{F}$ & $\mathrm{X}$ & & \\
\hline & $\mathrm{J}$ & $\mathrm{X}$ & & \\
\hline Safari Books & $\mathrm{H}$ & & $\mathrm{X}$ & \\
\hline Springer & $\mathrm{E}$ & & $\mathrm{X}$ & \\
\hline V-lex & $\mathrm{J}$ & $\mathrm{X}$ & & \\
\hline
\end{tabular}

Fonte: Autoria própria.

Das plataformas estrangeiras, apenas a Pearson e a V-lex têm interface em português. Todas as outras seis plataformas estrangeiras estão em inglês. No caso do Ebrary, a parte da pesquisa da plataforma já foi traduzida, mas muita coisa ainda continua em inglês. Nas bases estrangeiras, além da interface, grande parte do conteúdo também está em inglês, língua que já 
é comum em áreas como a Medicina, onde o conteúdo tem que ser o mais atual possível e nem sempre o tempo utilizado para tradução vale a pena.

A pergunta 49 , do quadro 41 , procura saber se a plataforma oferece a funcionalidade de pesquisa no texto completo do livro.

Quadro 41 - Busca no texto completo

\begin{tabular}{|c|c|c|c|c|}
\hline \multicolumn{5}{|c|}{ 49. É possível fazer busca no texto completo? } \\
\hline $\begin{array}{l}\text { Empresas } \\
\text { nacionais }\end{array}$ & $\begin{array}{l}\text { Biblio- } \\
\text { teca }\end{array}$ & Sim & Não & Comentários \\
\hline \multirow[t]{3}{*}{ Fórum } & $\mathrm{D}$ & $\mathrm{X}$ & & \\
\hline & $\mathrm{H}$ & $\mathrm{X}$ & & \\
\hline & I I & $\mathrm{X}$ & & \\
\hline Livraria Cultura & A & $\mathrm{X}$ & & Por livro. \\
\hline Livreiro & G & $\mathrm{X}$ & & \\
\hline Minha Biblioteca & $\mathrm{F}$ & $\mathrm{X}$ & & \\
\hline $\begin{array}{l}\text { Revista dos } \\
\text { Tribunais }\end{array}$ & $\mathrm{H}$ & $\mathrm{X}$ & & \\
\hline Saraiva & $\mathrm{J}$ & $\mathrm{X}$ & & \\
\hline \multicolumn{5}{|l|}{$\begin{array}{l}\text { Empresas } \\
\text { estrangeiras }\end{array}$} \\
\hline CABI & $\mathrm{E}$ & & $\mathrm{X}$ & \\
\hline \multirow[t]{2}{*}{ Ebrary } & $\mathrm{B}$ & $\mathrm{X}$ & & \\
\hline & $\mathrm{H}$ & $\mathrm{X}$ & & \\
\hline \multirow[t]{2}{*}{ Elsevier } & $\mathrm{C}$ & $\mathrm{X}$ & & \\
\hline & $\mathrm{E}$ & & $\mathrm{X}$ & \\
\hline McGraw-Hill & $\mathrm{C}$ & $\mathrm{X}$ & & \\
\hline \multirow[t]{2}{*}{ Pearson (EBSCO) } & $\mathrm{F}$ & $\mathrm{X}$ & & \\
\hline & $\mathrm{J}$ & $\mathrm{X}$ & & \\
\hline Safari Books & $\mathrm{H}$ & $\mathrm{X}$ & & \\
\hline Springer & $E$ & & $\mathrm{X}$ & \\
\hline V-lex & $\mathrm{J}$ & $X$ & & \\
\hline
\end{tabular}

Fonte: Autoria própria.

Outra grande vantagem dos livros eletrônicos em relação aos livros impressos é que eles permitem que sejam feitas pesquisas por palavras ou trechos em todo o texto. Melhor ainda é quando a plataforma permite pesquisar dentro de todos os livros em uma única pesquisa, poupando o tempo do usuário.

A biblioteca A afirmou que apenas é possível fazer a pesquisa dentro de cada livro, e na biblioteca E apenas é possível pesquisar dentro dos capítulos, pois é assim que os livros estão divididos para o acesso. A biblioteca $\mathrm{E}$ foi a única que disse não ser possível fazer buscas no texto completo.

$\mathrm{O}$ quadro 42 traz as respostas da pergunta 50, que procura saber se as plataformas oferecem funcionalidades úteis como marcar, anotar e comentar o texto. 
Quadro 42 - Funcionalidades da plataforma

\begin{tabular}{|c|c|c|c|c|}
\hline \multicolumn{5}{|c|}{ 50. Possui funcionalidades para marcar, anotar e comentar o texto? } \\
\hline $\begin{array}{l}\text { Empresas } \\
\text { nacionais }\end{array}$ & $\begin{array}{l}\text { Biblio- } \\
\text { teca }\end{array}$ & Sim & Não & Comentários \\
\hline \multirow[t]{3}{*}{ Fórum } & $\mathrm{D}$ & $\mathrm{X}$ & & \\
\hline & $\mathrm{H}$ & & & Não soube informar. \\
\hline & I & $\mathrm{X}$ & & É um comentário único para toda a base. \\
\hline Livraria Cultura & A & $\mathrm{X}$ & & \\
\hline Livreiro & $\mathrm{G}$ & $\mathrm{X}$ & & Sim, mas é única para todos os usuários. \\
\hline Minha Biblioteca & $\mathrm{F}$ & $\mathrm{X}$ & & $\begin{array}{l}\text { Sim, e isso fica salvo dentro do login. E também é } \\
\text { possível fazer anotações compartilhadas. }\end{array}$ \\
\hline $\begin{array}{l}\text { Revista dos } \\
\text { Tribunais }\end{array}$ & $\mathrm{H}$ & & & Não soube informar. \\
\hline Saraiva & $\mathrm{J}$ & $\mathrm{X}$ & & \\
\hline \multicolumn{5}{|l|}{$\begin{array}{l}\text { Empresas } \\
\text { estrangeiras }\end{array}$} \\
\hline CABI & $\mathrm{E}$ & & $\mathrm{X}$ & \\
\hline \multirow[t]{2}{*}{ Ebrary } & $\mathrm{B}$ & $\mathrm{X}$ & & $\begin{array}{l}\text { É possível marcar, salvar livros e estratégias de busca. } \\
\text { Não permite salvar comentários. }\end{array}$ \\
\hline & $\mathrm{H}$ & $\mathrm{X}$ & & \\
\hline \multirow[t]{2}{*}{ Elsevier } & $\mathrm{C}$ & $\mathrm{X}$ & & \\
\hline & $\mathrm{E}$ & & $\mathrm{X}$ & \\
\hline McGraw-Hill & $\mathrm{C}$ & $\mathrm{X}$ & & \\
\hline \multirow[t]{2}{*}{ Pearson (EBSCO) } & $\mathrm{F}$ & $\mathrm{X}$ & & \\
\hline & $\mathrm{J}$ & $\mathrm{X}$ & & \\
\hline Safari Books & $\mathrm{H}$ & $\mathrm{X}$ & & \\
\hline Springer & E & & $\mathrm{X}$ & \\
\hline V-lex & $\mathrm{J}$ & $X$ & & $\begin{array}{l}\text { "A V-lex tem um dispositivo, que por exemplo, se eu } \\
\text { faço uma busca sobre direito digital e não encontro o } \\
\text { que eu quero, eu deixo programado"... }\end{array}$ \\
\hline
\end{tabular}

Fonte: Autoria própria.

Uma função interessante é a que permite fazer marcações, destaques e anotações no livro eletrônico. Para que essa função esteja disponível é necessário que a plataforma ofereça uma área dedicada para cada usuário. Assim, ele poderá salvar as suas anotações e consultá-las quando precisar. Quase todas as bibliotecas, com exceção apenas da biblioteca E, responderam que as plataformas possuem alguma dessas funcionalidades.

A biblioteca I relatou que a Fórum chegou a oferecer essa função, mas como não havia separação dos usuários, as marcações seriam únicas para toda a base. Assim, se um usuário adicionasse um comentário, todos os usuários que abrissem a base poderiam ver e alterar esse comentário. A biblioteca I preferiu então que essa função fosse desligada por não funcionar de acordo com as necessidades da biblioteca. Essa função funcionava de maneira adequada apenas para uma assinatura pessoal da plataforma, não foi pensada para uma biblioteca. 
A biblioteca E disse que a plataforma não tem essa função, mas ela está disponível em alguns leitores de PDF. Essa é uma opção para os usuários que podem fazer o download dos livros.

A biblioteca $\mathrm{J}$ se mostrou muito satisfeita com a base V-lex. De acordo com o entrevistado, quando se faz login nessa base aparece um histórico de pesquisas e é possível criar alertas para assuntos de interesse.

A pergunta 51, do quadro 43, busca saber se é possível copiar ou imprimir o livro completo ou partes dele

Quadro 43 - É possível copiar e imprimir conteúdo?

\begin{tabular}{|c|c|c|c|}
\hline \multicolumn{4}{|c|}{ 51. É possível copiar e imprimir conteúdo? } \\
\hline & Sim & Não & Comentários \\
\hline $\mathrm{A}$ & & $\mathrm{X}$ & É bloqueado. \\
\hline B & $\mathrm{X}$ & & O limite de impressão é de $20 \%$ do livro. \\
\hline $\mathrm{C}$ & $\mathrm{X}$ & & É possível imprimir o que foi baixado ou diretamente da página, sem limite. \\
\hline $\mathrm{D}$ & $\mathrm{X}$ & & Sim. \\
\hline $\mathrm{E}$ & $\mathrm{X}$ & & "Sim, pois o PDF é aberto". \\
\hline $\mathrm{F}$ & $\mathrm{X}$ & & $\begin{array}{l}\text { "A plataforma permite fazer impressões mediante pagamento, não existe um } \\
\text { limite gratuito, só é possível imprimir se pagar". }\end{array}$ \\
\hline G & $\mathrm{X}$ & & $\begin{array}{l}\text { Não é possível copiar. Mas sobre a impressão, como os livros foram comprados } \\
\text { de fornecedores diferentes, cada um pode ter uma política diferente. Eu acredito } \\
\text { que se puder imprimir não é o texto completo, deve ter algum limite, mas eu } \\
\text { desconheço. }\end{array}$ \\
\hline $\mathrm{H}$ & $\mathrm{X}$ & & Tem um limite de páginas. \\
\hline $\mathrm{I}$ & $\mathrm{X}$ & & É possível imprimir uma parte do conteúdo. \\
\hline $\mathrm{J}$ & $\mathrm{X}$ & & O limite de impressão é 30 cópias (páginas). \\
\hline
\end{tabular}

Fonte: Autoria própria.

Algumas plataformas oferecem aos usuários a possibilidade de copiar e imprimir os livros. Quando é possível imprimir o conteúdo geralmente é um limite que varia de acordo com cada base: 20\% do livro (B), 30 páginas (J) ou outros, que as bibliotecas G, H e I não souberam dizer quais eram exatamente. A biblioteca precisa saber esse tipo de informação para poder orientar os usuários em caso de dúvida.

Apenas na biblioteca A não existe nenhuma possibilidade de impressão ou cópia do conteúdo. Na biblioteca F, é preciso pagar para imprimir qualquer parte do livro, não há nenhum limite para impressão gratuita.

Na biblioteca C, não há limite de impressão para os livros da plataforma. Nas bibliotecas D e E os usuários também podem imprimir quantas páginas desejarem, pois ,os livros estão em arquivos PDF sem bloqueios.

Na biblioteca F os usuários apenas podem imprimir os livros se pagarem por isso, não há um limite para a impressão gratuita. Isso leva ao questionamento de que se ao adquirir um livro eletrônico a compra é de um determinado formato ou do direito à leitura do conteúdo. $\mathrm{O}$ 
livro eletrônico é diferente por ser flexível e se alguém paga para poder ler um livro, a escolha do suporte no qual a leitura será feita não deveria ser determinada pelo vendedor. Se o livro é impresso apenas para leitura e não para a sua comercialização ilegal, essa é apenas uma comodidade que pode ser oferecida aos leitores. Afinal, mesmo com tantas limitações para quem adquire os livros legalmente, aqueles que pretendem fazê-lo de maneira ilegal sempre encontrarão uma alternativa.

As perguntas 52 a 55 foram comentadas anteriormente por causa do seu contexto. $\mathrm{O}$ último bloco de perguntas vai da 56 a 66 e trata do contrato e da licença de venda. A maioria das perguntas desse bloco não foi respondida pelas bibliotecas A e G, que declararam não ter um contrato de compra de livros eletrônicos. A pergunta 56, do quadro 44, busca saber quem é o responsável pela negociação com os vendedores em cada uma das bibliotecas, e se ele é bibliotecário.

Quadro 44 - Responsável pela negociação com os vendedores

\begin{tabular}{|l|l|}
\hline 56. Quem é responsável pela negociação com os vendedores? \\
\hline A & Não se aplica. \\
\hline B & $\begin{array}{l}\text { Bibliotecário (setor de compras). "Eu apenas digo o que eu quero. Mas quem vê o valor, se } \\
\text { há desconto, pagamento [são eles]. Às vezes nós ainda não temos o dinheiro, mas eles dão } \\
\text { um tempo a mais de acesso à base, mesmo que a biblioteca não tenha pago. Depois } \\
\text { descontamos, de um ano, ficamos só com } 7 \text { meses porque eles já deram } 3 \text { meses. Eles sabem } \\
\text { que é órgão público e que demora. Mas quem faz essa parte é o setor de compras". }\end{array}$ \\
\hline C & $\begin{array}{l}\text { A negociação é intermediada pelo departamento de compras, que repassa a informação para } \\
\text { o bibliotecário entrevistado. }\end{array}$ \\
\hline D & $\begin{array}{l}\text { Bibliotecário (entrevistado). "Eu faço a negociação, essa questão de conteúdo, como vai ser } \\
\text { acessado, porque toda essa negociação ocorre antes de fazer o projeto básico da contratação. } \\
\text { Todas as regras do negócio têm que estar bem definidas antes". }\end{array}$ \\
\hline E & $\begin{array}{l}\text { Primeiro o bibliotecário, depois o contrato passa para o setor de compras e depois para a } \\
\text { assessoria jurídica. }\end{array}$ \\
\hline F & Bibliotecário (não foi a pessoa entrevistada). \\
\hline G & Bibliotecário (entrevistado). \\
\hline H & Bibliotecário (entrevistado). \\
\hline I & Supervisor formado em administração. O entrevistado era bibliotecário. \\
\hline J & Bibliotecário (entrevistado). \\
\hline
\end{tabular}

Fonte: Autoria própria.

A negociação com os vendedores dos livros eletrônicos pode mudar muitos aspectos do pós-compra, como o direito de acesso aos arquivos (biblioteca D), a negociação de mais licenças de acesso (biblioteca $\mathrm{H}$ ), ou o direito de acesso a mais títulos pelo mesmo preço de um número maior de licenças (biblioteca J). A negociação é, portanto, tão importante quanto qualquer outra decisão da compra. Por isso a biblioteca pode conseguir um bom desconto ou outras vantagens relacionadas à plataforma se o seu representante na negociação entender bem sobre o funcionamento dos modelos de comercialização de livros eletrônicos. 
Na biblioteca A, como a compra foi feita direto com o distribuidor, em um modelo fechado e pensado para pessoas físicas e não para bibliotecas, não houve negociação alguma.

Em alguns casos ( $\mathrm{C}$ e E) os bibliotecários apenas dizem o que querem e a compra é negociada pelo setor de compras e pelo departamento jurídico da instituição. A comunicação entre esses setores precisa ser boa para que a biblioteca não sofra perdas por causa de uma má negociação. A biblioteca B é uma exceção, pois o setor de compras fica dentro da própria biblioteca e é coordenado por bibliotecários.

$\mathrm{Na}$ maioria das bibliotecas (B, D, F, G, H e J) os próprios bibliotecários são os responsáveis pela negociação com os vendedores. Isso exige diferentes habilidades deles, como o conhecimento sobre contratos e questões legais.

Na biblioteca I foi a única com uma resposta diferente. Lá, o responsável pela negociação é um supervisor formado em administração que trabalha na biblioteca. Ter um profissional especializado dentro da biblioteca é uma boa opção, pois ele saberá lidar com os trâmites legais e também entenderá melhor as necessidades da biblioteca.

A pergunta 57 , do quadro 45 , busca saber se os aspectos de acesso e utilização foram descritos na licença de uso.

Quadro 45 - Acesso e utilização na licença

\begin{tabular}{|l|c|c|l|}
\hline \multicolumn{5}{|c|}{ 57. A licença estipula de que forma o conteúdo será acessado e utilizado? } \\
\hline & Sim & Não & Comentários \\
\hline A & & X & Não se aplica. \\
\hline B & $\mathrm{X}$ & & "Sim. Consta tudo de maneira bem explicada e clara." \\
\hline C & X & & "Ela diz quem é usuário, quem não é." \\
\hline D & $\mathrm{X}$ & & \\
\hline E & X & & \\
\hline F & X & & \\
\hline G & & X & "Não, não recebemos nenhuma documentação sobre licença." \\
\hline H & X & & "Temos o compromisso de disponibilizar apenas para os servidores." \\
\hline I & X & & "Está tudo especificado no contrato, que o uso é restrito aos servidores." \\
\hline J & $\mathrm{X}$ & & "Sim, tem tudo no contrato." \\
\hline
\end{tabular}

Fonte: Autoria própria.

Quando essas questões foram elaboradas houve uma confusão entre os termos licença e contrato, confusão essa causada por falta de conhecimento dos termos jurídicos e talvez também por uma falha na tradução do inglês. Qualquer que tenha sido a razão, essa diferença foi mencionada no momento da entrevista por muitos entrevistados, e foi esclarecida no item 2.6.6 dessa dissertação. $\mathrm{O}$ entrevistado da biblioteca $\mathrm{C}$ também fez a gentileza de explicar a diferença entre eles:

A licença é elaborada pelo vendedor, já vem pronta e diz: você está comprando esse produto, pode disponibilizar para os seus usuários, pode fazer isso e aquilo, não pode comercializar nem distribuir pra [sic] quem não é usuário, 
não pode enviar pelo COMUT. No contrato vem a parte de manutenção e suporte (BIBLIOTECA C).

À exceção das bibliotecas A e G, todas as outras possuem um contrato onde constam informações sobre o acesso e o uso do material. Durante as entrevistas foi possível observar que as questões sobre o contrato de venda foram as que mais causaram dúvidas nos entrevistados, seguidas daquelas que tratavam do uso dos livros eletrônicos. A impressão que se teve foi que muitos entrevistados não conheciam o contrato tão bem, ou haviam esquecido muitos detalhes dele.

Na compra dos livros impressos, bastava que o bibliotecário soubesse quais títulos deveriam ser adquiridos. Entretanto, na compra de livros eletrônicos, é necessário que os bibliotecários conheçam os termos do contrato para garantir os direitos da biblioteca e evitar infrações ao direito autoral.

As bibliotecas A e G, que compraram de distribuidores, não possuíam contrato de venda. A falta de um contrato poderá trazer problemas quando as mesmas precisarem exigir seus direitos sobre os livros, que foram comprados por acesso perpétuo.

"No momento da compra não foi apresentada nenhuma licença de uso. O aparelho vem apenas com uma mini cartilha que mostra apenas alguns dados básicos. A licença de uso dos livros não está clara" (BIBLIOTECA A).

A pergunta 58, do quadro 46, procura saber se a licença esclarece quais são as pessoas autorizadas a acessar os livros.

Quadro 46 - Usuários autorizados a acessar e utilizar no contrato

\begin{tabular}{|l|c|c|l|}
\hline \multicolumn{5}{|c|}{ 58. A licença determina quem são os usuários autorizados a acessar e utilizar o conteúdo? } \\
\hline & Sim & Não & Comentários \\
\hline A & & & Não se aplica. \\
\hline B & X & & "Sim. Consta a faixa de IP dos usuários autorizados, quem eles são". \\
\hline C & X & & \\
\hline D & X & & São os servidores e ministros. \\
\hline E & X & & "São os empregados. E fornecemos o número do IP de todas as unidades". \\
\hline F & X & & \\
\hline G & & & Não se aplica. \\
\hline H & X & & Funcionários. \\
\hline I & X & & \\
\hline J & & X & "Existe o número de acessos, quem vai acessar depende da biblioteca". \\
\hline
\end{tabular}

Fonte: Autoria própria.

Em quase todas as bibliotecas (exceto $\mathrm{A}, \mathrm{G}$ e J), a licença determina claramente quem são os usuários autorizados a acessar o conteúdo. Apenas a biblioteca $\mathrm{J}$, que paga por um determinado número de acessos, disse que quem determina quem pode acessar os livros eletrônicos é a própria biblioteca. 
No contrato também deve constar quem são os usuários autorizados a acessar e utilizar o conteúdo. Conforme já foi verificado na questão 41, na maioria dos casos o acesso está autorizado apenas para o público alvo da biblioteca, que são os alunos das universidades e os servidores, empregados ou funcionários das instituições.

A questão 59, do quadro 47, busca saber se os termos do DRM e as restrições para leitura, impressão, cópia, download e empréstimo entre bibliotecas constam no contrato.

Quadro 47 - DRM e restrições do contrato

\begin{tabular}{|c|c|c|c|}
\hline \multicolumn{4}{|c|}{$\begin{array}{l}\text { 59. A licença descreve os termos de DRM e as restrições existentes para leitura, impressão, } \\
\text { cópia, download e empréstimo entre bibliotecas? }\end{array}$} \\
\hline & Sim & Não & Comentários \\
\hline A & - & - & Não se aplica. \\
\hline B & $\mathrm{X}$ & & $\begin{array}{l}\text { No contrato constam essas informações. O empréstimo entre bibliotecas não é } \\
\text { permitido para o material eletrônico. }\end{array}$ \\
\hline $\mathrm{C}$ & & & "Não temos DRM." \\
\hline $\mathrm{D}$ & $\mathrm{X}$ & & $\begin{array}{l}\text { "Não tem DRM. As restrições são para usuários fora do tribunal, é a única } \\
\text { restrição." }\end{array}$ \\
\hline $\mathrm{E}$ & - & - & $\begin{array}{l}\text { Não tem DRM nem restrições. Eles têm determinado em contrato, de acordo } \\
\text { com a lei de direito autoral. }\end{array}$ \\
\hline $\mathrm{F}$ & $\mathrm{X}$ & & $\begin{array}{l}\text { O que não discutimos muito foi a impressão paga, descobrimos como funciona } \\
\text { e deixamos quieto. A qualquer momento podemos implementar isso aqui, mas } \\
\text { por enquanto não. Está lá disponível para o usuário, se ele quiser conversar e } \\
\text { tentar ver se a gente consegue a impressão. Mas até o momento não teve }\end{array}$ \\
\hline G & - & - & Não se aplica. \\
\hline $\mathrm{H}$ & $\mathrm{X}$ & & Da Ebrary sim. Nenhuma tem empréstimo entre bibliotecas. \\
\hline I & $\mathrm{X}$ & & $\begin{array}{l}\text { Pela base não é possível baixar os livros. Não há restrição para leitura, mas tem } \\
\text { para impressão, cópia (mas na BD deles é possível, PDF apenas para leitura, } \\
\text { tem uma marca d'agua entrelaçada no texto da página). O contrato não prevê } \\
\text { empréstimo entre bibliotecas. }\end{array}$ \\
\hline $\mathrm{J}$ & $\mathrm{X}$ & & $\begin{array}{l}\text { "No contrato fala, mas eu não... Download não existe, a questão da impressão } \\
\text { ele fala da limitação, mas eu não lembro. Até porque não é uma coisa que é } \\
\text { feita. Não tem empréstimo entre bibliotecas, mas a compra é feita para a rede." }\end{array}$ \\
\hline
\end{tabular}

Fonte: Autoria própria.

Todas as bibliotecas (menos A e G) informaram que as restrições de uso constam no contrato. Nas questões seguintes, foi possível observar que as especificações sobre suporte técnico, preservação dos arquivos e garantia de acesso e armazenamento não constam no contrato de algumas bibliotecas. A partir das respostas das perguntas sobre a licença, é possível observar que enquanto os direitos das bibliotecas na compra nem sempre estão claros, os seus deveres e restrições sempre estão muito bem determinados. Por isso, as bibliotecas precisam ficar atentas aos contratos para garantir os seus direitos.

Em nenhuma das bibliotecas existe a possibilidade do empréstimo entre bibliotecas. Essa, junto com a impossibilidade de doação dos livros eletrônicos e de acesso a usuários externos, é mais uma demonstração de como eles podem ser pouco democráticos e excludentes. O empréstimo entre bibliotecas é uma demonstração de cordialidade e cooperação entre as 
instituições, que optam por trabalhar em rede devido à impossibilidade dos centros informacionais de suprirem sozinhos todas as necessidades dos seus usuários. A falta de um empréstimo entre bibliotecas para os livros eletrônicos dificulta o trabalho em rede.

As bibliotecas C, D e E informaram que os seus livros eletrônicos não possuem bloqueios por DRM. A ausência desses bloqueios oferece mais possibilidades no uso dos livros eletrônicos.

Os aspectos sobre a impressão foram respondidos na questão 51, e o download foi tratado na questão 42.

O quadro 48 traz as respostas da pergunta 60, que indagou sobre o serviço contratado, principalmente sobre o suporte técnico.

Quadro 48 - O que o serviço contratado inclui

\begin{tabular}{|l|l|}
\hline $\begin{array}{l}\text { 60. Qual o nível de serviço contratado e o que ele inclui (suporte técnico local e remoto, } \\
\text { atendimento em idioma local, prazo para atendimento de solicitações, serviços específicos a } \\
\text { serem disponibilizados)? }\end{array}$ \\
\hline A & Não se aplica. \\
\hline B & Sim. \\
\hline C & O suporte é feito por $e$-mail e em inglês. \\
\hline D & $\begin{array}{l}\text { "Inclui o suporte técnico e o atendimento em português e tem prazo pra [sic] atendimento } \\
\text { das solicitações. Em alguns colocamos que têm que ser atendidos em até 24h". }\end{array}$ \\
\hline E & "Sim, os representantes são brasileiros e ficam à disposição para o que a gente precisar". \\
\hline F & $\begin{array}{l}\text { As solicitações são atendidas imediatamente, no mesmo dia. Mas o entrevistado não soube } \\
\text { informar se isso consta no contrato. }\end{array}$ \\
\hline G & Não se aplica. \\
\hline H & Inclui tudo. O tempo de resposta da Safari é melhor que o da Ebrary (mais de 24h). \\
\hline I & $\begin{array}{l}\text { Suporte técnico remoto, atendimento em português, não tem prazo para atender as } \\
\text { solicitações. }\end{array}$ \\
\hline J & $\begin{array}{l}\text { Atendimento técnico só remoto, em idioma local. Não lembro se o prazo para atender às } \\
\text { solicitações consta nos contratos, mas o atendimento geralmente é imediato. }\end{array}$ \\
\hline
\end{tabular}

Fonte: Autoria própria.

Essa pergunta não se aplica às bibliotecas A e G, que não possuem contratos específicos para os livros eletrônicos. A biblioteca A menciona apenas o suporte para o aparelho Kobo, que, assim como o suporte para os livros, não é especial para bibliotecas. A biblioteca A nunca teve problemas que necessitassem de um suporte técnico. Como os livros eletrônicos da biblioteca $\mathrm{G}$ são comprados com um distribuidor, a biblioteca faz o download único no site da editora e depois não tem mais nenhum contato.

As bibliotecas B, E, F, H e I contam com suporte técnico em português. O entrevistado da biblioteca $\mathrm{F}$ não soube informar se o prazo para atendimento das solicitações consta no contrato, mas ele está satisfeito com o atendimento, que segundo ele é imediato.

Nenhuma biblioteca relatou problemas com o suporte das empresas estrangeiras. Essas empresas costumam ter um representante no Brasil, e o atendimento é remoto, por telefone ou 
e-mail. A única biblioteca que soube informar com certeza se o prazo para atendimento das solicitações consta no contrato foi a biblioteca D. As outras bibliotecas não souberam dizer se havia um prazo no contrato, mas elas não tiveram problemas com o suporte. Se elas tivessem algum problema com o suporte provavelmente consultariam o contrato para saber se há um prazo determinado.

$\mathrm{Na}$ elaboração do contrato, para evitar surpresas ruins, é importante que as condições do suporte, se ele será presencial ou remoto, e qual é o prazo de resposta, estejam escritas em detalhes. Apesar da maioria das bibliotecas não se lembrar do prazo de resposta contratual, quando o suporte é considerado insatisfatório pode não haver renovação da assinatura, como aconteceu com a biblioteca $\mathrm{J}$.

Apenas no caso da biblioteca $\mathrm{C}$ o suporte é feito em inglês. A falta de um suporte no idioma local pode causar graves problemas na comunicação entre a biblioteca e o fornecedor, por isso o ideal é que ele esteja em português.

Para tratar dos direitos da biblioteca, cada entrevistado mencionou o aspecto que the chama mais a atenção. A pergunta 61 , do quadro 49 , é bem aberta e por isso resultou em respostas tão distintas.

Quadro 49 - Direitos da biblioteca

\begin{tabular}{|l|l|}
\hline \multicolumn{2}{|l|}{ 61. Quais são os direitos da biblioteca? } \\
\hline A & $\begin{array}{l}\text { "Não existe nenhuma informação sobre a continuidade de acesso. O que é um risco de compra para o } \\
\text { livro digital. Se a rede cair, é mais difícil recorrer. Para agilizar o processo, não foram estudados os } \\
\text { direitos que podiam emperrar a compra. A decisão foi agir antes de conhecer todos os detalhes. Na } \\
\text { época foi um projeto embrionário, que não existia em outras bibliotecas". }\end{array}$ \\
\hline B & $\begin{array}{l}\text { "Eles mandam um aviso dizendo que o livro foi muito baixado. Só se estiver no contrato, mas eu não } \\
\text { sei porque nunca houve isso para livros, só com revistas". }\end{array}$ \\
\hline C & Os livros podem ser acessados apenas na rede da biblioteca, que não detém os arquivos com os livros. \\
\hline D & $\begin{array}{l}\text { "São mais deveres do que direitos. Os direitos autorais é o seguinte, é para uso do tribunal e não posso } \\
\text { passar respeitando mesmo a legislação". }\end{array}$ \\
\hline E & $\begin{array}{l}\text { "Isso foi discutido algumas vezes até lá no portal Capes com os editores. Eles falam que eles têm o } \\
\text { backup [não lembra o nome]. Eles falam que já está tudo previsto caso aconteça alguma coisa, eles já } \\
\text { têm o procedimento. Pelo menos essas editoras maiores, essas que a gente tem contato, eles falam } \\
\text { como que entra, o que tem que fazer. Mas não estou lembrando agora como é. Na última vez que eu } \\
\text { fui em uma reunião na Capes tinha essa discussão". }\end{array}$ \\
\hline F & Os livros estão disponíveis para acesso na rede da biblioteca. \\
\hline G & Não se aplica. \\
\hline H & O contrato da Safari está traduzido e tem todos os conteúdos, e a limitação, pagamento, rescisão. \\
\hline I & Garantia de acesso e permanência com a última atualização em formato PDF. \\
\hline J & $\begin{array}{l}\text { "O que podemos fazer é permitir o acesso aos nossos usuários dentro do limite que temos de licenças } \\
\text { disponibilizadas. Mas eu não posso repassar isso adiante, cláusula contratual. Eu não posso pegar a } \\
\text { minha senha e dar para você usar. Isso fica bem claro para os alunos, o acesso é seu, você pode acessar. } \\
\text { Até porque se alguém pegar a sua senha e for imprimir alguma coisa o ônus é do seu bolso". }\end{array}$ \\
\hline
\end{tabular}

Fonte: Autoria própria.

Na biblioteca A o entrevistado é muito consciente dos problemas que podem surgir por essa compra não ter sido feita em termos específicos para uma biblioteca. Ainda assim, a biblioteca resolveu assumir esse risco para oferecer algo novo aos seus usuários. 
A biblioteca $\mathrm{B}$ falou dos direitos em caso de uso indevido, e respondeu às perguntas 61 e 62 ao mesmo tempo.

As bibliotecas C, F, E e I mencionaram os direitos de acesso. A biblioteca C mencionou também que a biblioteca não detém os arquivos com os livros. Nos modelos de compra, a biblioteca adquire apenas o acesso aos livros, por isso seus direitos se restringem à leitura. $\mathrm{A}$ biblioteca E citou a questão do backup, que remete à garantia de acesso ao material comprado que será tratada na questão 64. A garantia de acesso também foi mencionada pela biblioteca I, que afirmou possuir a última versão dos livros em formato PDF.

A biblioteca $\mathbf{J}$ destacou que o direito da biblioteca é de uso dos livros, e que eles não podem ser livremente copiados e distribuídos.

A resposta da biblioteca D traz uma crítica quando o entrevistado diz que "são mais deveres do que direitos". Isso é comprovado quando se observam todas as restrições impostas às bibliotecas.

A biblioteca $\mathrm{H}$ mencionou o contrato com a empresa Safari, que é completo, e é onde constam os direitos da biblioteca.

A pergunta 62 , do quadro 50, busca descobrir se a biblioteca está consciente de quais podem ser as consequências para ela caso algum usuário faça uso inapropriado dos livros, se a biblioteca adotou as devidas medidas legais para evitar que a culpa recaia sobre ela.

Quadro 50 - Uso impróprio dos livros eletrônicos pelos usuários

62. A biblioteca está protegida de uso não autorizado por parte dos usuários se ela tomou as medidas necessárias para prevenir esse uso (ex.: quebra do DRM, impressão do livro completo, cópia não autorizada)?

\begin{tabular}{|l|l|}
\hline A & "Não sei." \\
\hline B & $\begin{array}{l}\text { "Eles mandam um aviso dizendo que o livro foi muito baixado. Só se estiver no contrato, } \\
\text { mas eu não sei porque nunca houve isso para livros, só com revistas". }\end{array}$ \\
\hline C & $\begin{array}{l}\text { "Sim porque o acesso só é feito com senha. Como o acesso é apenas interno, se a pessoa não } \\
\text { estiver logada na rede institucional ela não acessa". }\end{array}$ \\
\hline D & $\begin{array}{l}\text { Se a biblioteca fizer uso não autorizado vai ser aberto um processo administrativo e } \\
\text { dependendo até um processo penal. }\end{array}$ \\
\hline E & Não, se o usuário quiser ele pode imprimir o livro completo. \\
\hline F & $\begin{array}{l}\text { "Sim, o contrato estipula a proteção dos direitos autorais, que já foram pagos pela biblioteca. } \\
\text { Então se alguém fizer uma utilização indevida a biblioteca está protegida contra isso". }\end{array}$ \\
\hline G & $\begin{array}{l}\text { "Eu diria que sim porque o download é feito apenas no tablet que é corporativo e o download } \\
\text { foi único, o próprio sistema não permite a cópia para outro dispositivo. O dispositivo não é } \\
\text { particular, é da empresa. E mesmo aqueles que permitirem uma impressão, ela é limitada, } \\
\text { não é possível imprimir o conteúdo completo para outro uso e nem fazer uma cópia do próprio } \\
\text { livro eletrônico para outro dispositivo". }\end{array}$ \\
\hline H & Não. Mas o sistema bloqueia automaticamente se alguém tentar imprimir o livro inteiro. \\
\hline I & Não soube informar. \\
\hline J & $\begin{array}{l}\text { As limitações são feitas pela própria base. Tudo o que é feito fica registrado na conta de cada } \\
\text { aluno. }\end{array}$ \\
\hline
\end{tabular}

Fonte: Autoria própria. 
Cada biblioteca toma as providências que parecem melhores para evitar o uso inapropriado dos livros, que pode levar a um processo judicial. Na biblioteca $\mathrm{C}$ a decisão foi de restringir o acesso, enquanto as bibliotecas D e E preferiram manter o acesso mais amplo, dividindo a responsabilidade pelo uso com os usuários.

$\mathrm{Na}$ biblioteca $\mathrm{A}$, onde os termos não estão claros, a biblioteca resolveu assumir o risco caso haja algum problema. A situação legal é mais difícil para as bibliotecas pequenas, que não conseguem adotar os modelos existentes de aquisição de livros eletrônicos para bibliotecas. As normas legais não são claras no aspecto do empréstimo de livros por bibliotecas, e ainda menos quando isso envolve os livros eletrônicos. Cabe à cada biblioteca decidir o que lhe parece correto, e depois apenas torcer para que isso não lhe traga problemas já que não há previsão legal.

Nas bibliotecas B e E, quando o vendedor percebeu que o número de downloads estava muito acima do normal entrou em contato diretamente com a biblioteca, que buscou uma solução para o problema. Essa foi uma solução amigável para o problema, e nessa pesquisa não foi encontrado nenhum caso de processo judicial. Mas o uso de livros eletrônicos em bibliotecas é recente e é importante ter cuidado com os aspectos legais para evitar maiores problemas.

$\mathrm{Na}$ opinião do entrevistado da biblioteca $\mathrm{F}$, a biblioteca está protegida pois já pagou pelos direitos autorais para ter acesso ao material. Entretanto, mesmo que a biblioteca tenha pago pelo direito de uso, podem haver complicações no caso de uso inapropriado.

Para as bibliotecas G, H e J as limitações são feitas pela própria base. Realmente, os vendedores fazem o que é possível para evitar a pirataria, mas a tecnologia tem possibilidades infinitas, e quem entende do assunto pode encontrar rapidamente uma maneira de fazer o que bem entende com os arquivos digitais.

A pergunta 63, do quadro 51, busca obter mais detalhes sobre a garantia de acesso aos arquivos dos livros eletrônicos adquiridos, para saber se a responsabilidade de preservação é da biblioteca ou do vendedor. A questão da preservação digital foi tratada na pergunta 35. 
Quadro 51 - Responsável pelo armazenamento e preservação dos arquivos no contrato

\begin{tabular}{|c|c|}
\hline \multicolumn{2}{|r|}{$\begin{array}{l}\text { 63. A licença determina quem é responsável pelo armazenamento e preservação dos } \\
\text { arquivos? }\end{array}$} \\
\hline $\mathrm{A}$ & Não se aplica. \\
\hline $\mathrm{B}$ & "Sim, a própria editora é responsável". \\
\hline $\mathrm{C}$ & $\begin{array}{l}\text { "Na verdade, a gente não armazena, só tem acesso. Nem o livro perpétuo fica com a gente } \\
\text { aqui". }\end{array}$ \\
\hline $\mathrm{D}$ & $\begin{array}{l}\text { A responsabilidade pela preservação dos livros é da biblioteca. "ele passa pra [sic] gente, por } \\
\text { meio de FDP a gente faz a baixa e a partir daí a responsabilidade é da biblioteca". }\end{array}$ \\
\hline $\mathrm{E}$ & "A empresa que vendeu é responsável, nós só temos os metadados". \\
\hline $\mathrm{F}$ & $\begin{array}{l}\text { "O armazenamento está disponível dentro de uma plataforma deles mesmo, então acho que } \\
\text { esse cuidado todo remete a eles". O entrevistado não soube dizer se isso consta no contrato. }\end{array}$ \\
\hline $\mathrm{G}$ & Não se aplica. \\
\hline $\mathrm{H}$ & "A licença não fala sobre isso". \\
\hline I & "Eles que são responsáveis pela disponibilização do acesso do arquivo". \\
\hline $\mathrm{J}$ & $\begin{array}{l}\text { "Consta que são as empresas, como nós acessamos on-line tudo são eles que”... [são } \\
\text { responsáveis]. }\end{array}$ \\
\hline
\end{tabular}

Fonte: Autoria própria.

Essa pergunta não se aplica às bibliotecas $\mathrm{A}$ e $\mathrm{G}$, que não possuem contrato. A licença da biblioteca $\mathrm{H}$ não menciona quem é o responsável.

Quando a compra é feita por assinatura, é comum que os livros fiquem armazenados apenas na plataforma do vendedor, como é o caso das bibliotecas B, C, F, I e J. Mas, mesmo que a compra seja feita por acesso perpétuo, nem sempre os livros ficam sob responsabilidade da biblioteca, isso depende do vendedor. Esse é o caso da biblioteca E, que comprou por acesso perpétuo, mas não é responsável pelo armazenamento dos arquivos. Se a biblioteca tem a intenção de armazenar e preservar os arquivos, como é o caso da biblioteca $\mathrm{D}$, é importante que ela não só faça a aquisição por acesso perpétuo, mas também que verifique se o vendedor fornece os arquivos dos livros.

Em seis bibliotecas os vendedores são os responsáveis pela preservação dos livros. Isso tira uma grande responsabilidade das mãos da biblioteca, ao mesmo tempo em que se houver algum problema e o vendedor não fizer a preservação corretamente, ou se ele falir e desaparecer, mesmo que a biblioteca consiga recuperar o dinheiro, não terá os livros. Esse pode ser um problema gravíssimo de preservação da memória coletiva para os livros que são lançados apenas em formato eletrônico e vendidos com exclusividade por uma editora.

$\mathrm{O}$ entrevistado da biblioteca $\mathrm{C}$ disse que já foi oferecido o serviço de uma seguradora para a biblioteca, que manteria os arquivos. Mas a biblioteca $\mathrm{C}$ se recusou a pagar por esse serviço pois seria muito caro. De acordo com a explicação do entrevistado, o serviço citado parece ser um dark archive, citado na questão 35.

A biblioteca $\mathrm{D}$, como já pôde ser observado pelo seu perfil e pela exigência de compra por acesso perpétuo, é ela mesma a responsável pela preservação dos arquivos. A preservação 
digital é complicada e exige atenção a muitos detalhes, mas foi uma escolha feita pela instituição como a melhor opção para garantir o acesso aos livros comprados.

A pergunta 64 , do quadro 52, busca saber quais são as garantias de acesso ao material comprado caso uma editora decida sair da plataforma.

Quadro 52- Garantia de acesso ao material

\begin{tabular}{|c|c|c|c|}
\hline \multicolumn{4}{|c|}{$\begin{array}{l}\text { 64. Caso uma editora decida sair da plataforma, a biblioteca tem alguma garantia de acesso } \\
\text { ao material comprado? }\end{array}$} \\
\hline & Sim & Não & Comentários \\
\hline A & & & Não se aplica. \\
\hline $\mathrm{B}$ & & & $\begin{array}{l}\text { Eles nunca comunicaram nenhuma retirada. Isso nunca aconteceu, nunca } \\
\text { descobrimos. }\end{array}$ \\
\hline $\mathrm{C}$ & $\mathrm{X}$ & & Só se for perpétuo. \\
\hline $\mathrm{D}$ & $\mathrm{X}$ & & A biblioteca já possui todos os PDFs dos livros adquiridos. \\
\hline $\mathrm{E}$ & & & Não se aplica. \\
\hline $\mathrm{F}$ & & & Não soube informar. \\
\hline $\mathrm{G}$ & & & Não se aplica. \\
\hline $\mathrm{H}$ & $\mathrm{X}$ & & Na Ebrary, tem garantia ao material que já foi inserido. \\
\hline I & & $\mathrm{X}$ & $\begin{array}{l}\text { Se a empresa saísse do mercado entrariam as cláusulas do contrato de multa por } \\
\text { rescisão. A biblioteca receberia a multa mas ficaria sem os livros. }\end{array}$ \\
\hline $\mathbf{J}$ & & $\mathrm{X}$ & $\begin{array}{l}\text { Se uma editora sai da plataforma, a edição do livro continua lá mas não é } \\
\text { atualizada. Mas se a plataforma sai do mercado e rompe o contrato, a justiça é } \\
\text { acionada. }\end{array}$ \\
\hline
\end{tabular}

Fonte: Autoria própria.

Essa pergunta não se aplica ao caso das bibliotecas $A$ e $G$ pois elas não possuem um contrato, e da biblioteca E, pois, ela não possui nenhuma assinatura ativa.

Vasileiou, Rowley e Hartley (2012) afirmam que o arquivamento, a garantia de acesso e a preservação digital devem constar no contrato de compra dos livros eletrônicos. Grigson (2011) também menciona que a garantia de acesso deve constar no contrato. A garantia de acesso significa que mesmo que o vendedor tenha problemas no futuro ou que alguma editora saia da plataforma, a biblioteca tem o direito de acessar o material pago. Esse acesso pode ser feito por um serviço de preservação do tipo dark archive (mencionado na questão 35) mantido pelo vendedor ou pela biblioteca.

Os vendedores ficam felizes em informar quando novos títulos são inseridos na base, mas o direito da biblioteca de ter acesso aos livros que estavam lá quando a base foi assinada ainda é obscuro. A biblioteca B nunca percebeu e nem foi informada sobre a retirada de nenhum livro da base.

Para a biblioteca $\mathrm{C}$, apenas existe a garantia de acesso para os livros comprados por acesso perpétuo, e não para as assinaturas. Entretanto, essa biblioteca já conseguiu garantir o acesso ao material disponível durante o período de assinatura que foi pago, mesmo que ela não seja renovada. Por exemplo, se a biblioteca assina uma plataforma no período de 2013 e depois 
não tem condições de renová-la em 2014, continua tendo acesso ao que estava disponível em 2013, mas esse conteúdo não é atualizado. No início o vendedor cortou o acesso a tudo, mas depois de 3 a 4 meses de insistência a biblioteca conseguiu recuperar o acesso.

Atualmente a biblioteca D possui os PDF de todos os livros adquiridos. Mas essa biblioteca já assinou uma base durante um período, e quando a assinatura chegou ao fim perdeu o acesso a tudo. Como a biblioteca $\mathrm{D}$ assina a plataforma de uma única editora, foi perguntado o que aconteceria se o livro de algum autor fosse retirado, e foi dito que o vendedor deve apresentar uma justificativa pois os livros comprados estão especificados no contrato.

Para a biblioteca F isso ainda não está acontecendo, pois, a tendência é que mais editores entrem na Minha Biblioteca por ela ser recente. O que já aconteceu com essa biblioteca foi que a Artmed fazia parte da Pearson e agora está na Minha Biblioteca. Então a biblioteca F tem acesso a livros dessa editora nas duas plataformas. O que a biblioteca percebeu foi que alguns títulos mais importantes deixaram de fazer parte do acervo.

A biblioteca $\mathrm{H}$ possui garantia contratual de acesso aos livros que já foram inseridos no Ebrary.

As bibliotecas I e J não tem garantia de acesso ao material. Para a biblioteca I, se o vendedor sair do mercado, a biblioteca recebe o valor da multa, mas fica sem os livros. A biblioteca $\mathbf{J}$ disse que as cláusulas do contrato são minuciosas, e preveem o período no qual o serviço deve ser disponibilizado.

O quadro 53 apresenta as respostas da questão 65, que buscou saber se o contrato entre o vendedor e a biblioteca prevê que a biblioteca receba cópias dos livros caso o vendedor saia do mercado. A questão 65 é um aprofundamento da questão 64, pois nesse caso a garantia de acesso da biblioteca envolveria a posse das cópias digitais dos livros. 
Quadro 53 - Cópias dos livros no encerramento da plataforma

\begin{tabular}{|l|l|l|l|l|}
\hline \multicolumn{6}{|l|}{$\begin{array}{l}\text { 65. O vendedor vai oferecer cópias para arquivo de algum livro comprado caso encerre sua } \\
\text { plataforma ou seus negócios? }\end{array}$} \\
\hline & Sim & Não & Comentários \\
\hline A & & & Não se aplica. \\
\hline B & & X & "Quando acaba a assinatura a biblioteca perde tudo". \\
\hline C & X & & \\
\hline D & X & & A biblioteca já possui os PDF. \\
\hline E & X & & $\begin{array}{l}\text { "A editora CABI já forneceu o backup dos livros em CD. Nessas compras que } \\
\text { fizemos, só conseguimos isso com essa editora. Tem um sistema que ele está } \\
\text { automaticamente com todos esses backups. Se a gente não acessar na editora } \\
\text { vai acessar nele. Eu não estou lembrando o nome agora, é um que está no portal } \\
\text { Capes". }\end{array}$ \\
\hline F & X & $\begin{array}{l}\text { "O contrato já rege um desconto de 40\% para adquirir o livro físico para todos } \\
\text { os livros que estão disponíveis no Minha Biblioteca e na Pearson. Então é a } \\
\text { instituição que decide se quer comprar ou não os livros". }\end{array}$ \\
\hline G & Não se aplica. \\
\hline H & X & $\begin{array}{l}\text { A RT só concordou em entregar depois de ser pressionada por um conjunto de } \\
\text { bibliotecas. Mas não entregaram o material do ano passado. "Eles deveriam } \\
\text { entregar os livros em PDF em um DVD todos os anos. Eles dizem que vão } \\
\text { fazer mais na prática não recebi nenhum CD até hoje, mas porque continuamos } \\
\text { renovando (RT). Não recebemos de nenhuma. E as estrangeiras não falam } \\
\text { sobre isso". }\end{array}$ \\
\hline I & X & X & $\begin{array}{l}\text { "Mas a Ebrary fala que se rescindirmos o contrato temos direito ao conteúdo } \\
\text { disponível até o dia da assinatura. Se eu assinei por dois anos, teria direito aos } \\
\text { livros que foram disponibilizados durante os dois anos da minha assinatura". }\end{array}$ \\
\hline J & X biblioteca já possui as cópias. \\
\hline
\end{tabular}

Fonte: Autoria própria.

Essa pergunta não se aplica às bibliotecas A e G, pois elas informaram que não possuem um contrato de compra.

Nem todas as editoras fornecem os arquivos ao fim do contrato. A biblioteca $\mathrm{C}$ acredita que mesmo que isso conste no contrato, não tem como uma empresa que quebrou oferecer os arquivos.

As bibliotecas B, F e J não vão receber os arquivos caso o vendedor saia do mercado. A biblioteca B declarou que perde todo o acesso aos arquivos se o vendedor sair do mercado. Para a biblioteca $\mathrm{F}$, o vendedor ofereceu um desconto para a compra dos livros impressos, e cabe à biblioteca decidir se comprará nesse formato para garantir o acesso.

Para as bibliotecas C, D, E, H e I os vendedores informaram que pretendem fornecer a cópias, e as bibliotecas D, E e I já possuem essas cópias. A editora Revista dos Tribunais concordou em enviar cópias dos livros para a biblioteca $\mathrm{H}$, mas ela ainda não recebeu esse material. Mesmo que a empresa afirme que vai fornecer os arquivos, a biblioteca deve lutar para que o combinado seja cumprido. Talvez exigir essa cópia antecipadamente seja a melhor 
opção para evitar problemas com um vendedor que já saiu do mercado, e tudo isto deve constar explicitamente no contrato.

A questão 66, cujas respostas estão no quadro 54, busca identificar quais foram as dificuldades legais encontradas pelas bibliotecas e como elas foram resolvidas.

Quadro 54 - Principais dificuldades legais encontradas para a compra

\begin{tabular}{|l|l|}
\hline $\begin{array}{l}\text { 66. Quais foram as principais dificuldades legais encontradas para a compra (ex.: licitação)? } \\
\text { Como elas foram resolvidas? }\end{array}$ \\
\hline A & A biblioteca não teve dificuldades para a compra. \\
\hline B & $\begin{array}{l}\text { Não tiveram dificuldades pois as vantagens de acesso e economia de espaço são muito bem } \\
\text { explicadas para a reitoria, que é quem libera a verba. }\end{array}$ \\
\hline C & $\begin{array}{l}\text { "Legal não, na verdade tem o contrato e a licença que a gente não tem como mexer nisso, e } \\
\text { essas dificuldades quando você deixa de assinar um periódico". }\end{array}$ \\
\hline D & $\begin{array}{l}\text { Tiveram que justificar para a "assessoria jurídica a intenção de comprar o livro digital e } \\
\text { porque estamos comprando digital e o impresso ao mesmo tempo. Porque ainda estamos } \\
\text { criando uma cultura na instituição". }\end{array}$ \\
\hline E & $\begin{array}{l}\text { A biblioteca foi muito questionada pela assessoria jurídica sobre o acesso e a assinatura } \\
\text { porque os editores eram exclusivos e havia inexigibilidade de licitação. }\end{array}$ \\
\hline F & Não tiveram problemas com a compra. \\
\hline G & $\begin{array}{l}\text { Não teve dificuldades pois a compra de livros eletrônicos foi encaixada na compra com o } \\
\text { mesmo fornecedor de livros impressos. }\end{array}$ \\
\hline H & $\begin{array}{l}\text { "Não tivemos problemas porque compramos com consenso e carta de exclusividade, para } \\
\text { todas". }\end{array}$ \\
\hline I & $\begin{array}{l}\text { "Para a contratação da primeira série foi tranquilo porque era um produto exclusivo, mas eu } \\
\text { não sei como ficaria se fosse comprar a obra solta, mais de um, se é exclusividade de venda } \\
\text { da editora ou se também é vendido pra livrarias, e aí teria que entrar com o processo de } \\
\text { licitação, ainda não passamos por isso". }\end{array}$ \\
\hline J & $\begin{array}{l}\text { "Não teve nenhuma dificuldade, a compra foi muito tranquila mesmo. Eles mandaram o } \\
\text { contrato, eu passei para o meu [departamento] jurídico que analisou, deu o aval, o reitor } \\
\text { assinou e pronto, estava feito o contrato. Não teve nem dor de cabeça". }\end{array}$ \\
\hline
\end{tabular}

Fonte: Autoria própria.

A compra em órgãos públicos deve seguir um processo rígido de licitação, que é regido por uma lei desatualizada, o que pode prejudicar a aquisição de material eletrônico. As bibliotecas $\mathrm{H}$ e I citaram a carta de exclusividade que muitas editoras possuem e que leva à inexigibilidade de licitação, como explicado por Fernandes (2015) e Granjeiro e Cardoso (2013). A carta de exclusividade comprova que não há concorrência para o material oferecido, que ele é vendido apenas por esse fornecedor.

Uma sugestão de Fernandes (2015) para o processo de compra por inexigibilidade com a carta de exclusividade é que a empresa apresente o preço pelo qual o produto foi vendido para três instituições diferentes. Como não há concorrência, essa é uma maneira de garantir que seja cobrado o preço de mercado (FERNANDES, 2015). Bueno (2015) afirma ainda que a carta de exclusividade deve ser emitida por uma associação de classe para que a biblioteca não tenha problemas com a procuradoria ou com uma auditoria. 
A UFRGS foi pioneira no Brasil ao fazer o primeiro pregão para a compra de livros eletrônicos (BUENO, 2015). A biblioteca da UFRGS trabalhou muito na elaboração do edital para que ele atendesse a todas as suas necessidades como uma biblioteca, e fosse diferente da compra para pessoas físicas (BUENO, 2015). A principal dificuldade ao se fazer um pregão de livros eletrônicos é conseguir descrever corretamente no edital qual deve ser o modelo de negócios para a aquisição (BUENO, 2015). Os diferentes modelos que cercam a aquisição de livros eletrônicos são a principal dificuldade na compra por pregão, onde a biblioteca deve dizer, antecipadamente, exatamente o que quer adquirir e em quais termos.

As bibliotecas D e E precisaram explicar para a assessoria jurídica para quê e porquê estavam comprando livros eletrônicos, como funcionavam o acesso e a assinatura, principalmente porque a venda era por exclusividade. Conforme descrito por Rubel (2007), a aquisição muitas vezes exige um trabalho conjunto entre a biblioteca, a assessoria jurídica e o setor de compras.

As bibliotecas A, F e G não tiveram problemas na compra dos livros eletrônicos. A biblioteca F é de uma universidade particular e também faz compras pelo processo de licitação, mas nada os impede de fazer compras diretamente.

Em seis entrevistas (B, C, D, E, I e J) a compra de livros eletrônicos foi comparada em algum momento com a de periódicos. As semelhanças são muitas e as bibliotecas já estão mais acostumadas com as bases de periódicos. Os periódicos eletrônicos também possuem alto custo de manutenção e as bibliotecas pagam pelo seu acesso sem ter propriedade do conteúdo (SERRA; SILVA, 2014).

Ao final de todas as entrevistas foi perguntado se havia mais algum comentário ou algum aspecto importante da compra de livros eletrônicos ainda faltava ser mencionado, mas a impressão geral foi de que a entrevista havia sido bem completa.

O comentário da biblioteca $\mathrm{C}$ foi que o livro eletrônico ainda não chegou ao seu formato ideal pois ele ainda é pensado como livro em papel. As editoras ainda estão se ajustando ao comércio dos livros eletrônicos, então muitas aparecem e desaparecem, enquanto outras se unem. Por esse comentário é possível perceber a opinião de que o mercado dos livros eletrônicos ainda está mudando e, assim como o próprio livro eletrônico, ainda não chegou ao seu auge.

Para a biblioteca E, é importante fazer uma boa gestão da aquisição, verificar quais títulos são usados e quais são os modelos existentes pois já existem modelos novos e é importante ter tudo bem claro. 
A biblioteca F mencionou a questão da aceitação dos livros eletrônicos pelo MEC na avaliação das bibliotecas universitárias, pois se a biblioteca tiver o livro em formato eletrônico pode reduzir a quantidade de livros físicos. De acordo com a biblioteca F o MEC já aceita os livros eletrônicos, mas ainda não estudou bem a questão do acesso multiusuário, onde teoricamente existe um livro para cada usuário. Isso significa que a biblioteca dispõe de mais livros do que a porcentagem exigida por eles, que trata de uma quantidade de exemplares físicos para um determinado número de vagas. Quando a biblioteca possui livros eletrônicos eles aceitam uma redução de $30 \%$ a $40 \%$ da quantidade de livros físicos (BIBLIOTECA F). Mas o entrevistado pensa que essa redução poderia ser ainda maior, já que o livro eletrônico pode ser consultado por todos que precisarem dele simultaneamente. 


\section{CONCLUSÃO}

Todos os objetivos propostos para esta pesquisa foram alcançados. O objetivo geral era "Identificar os modelos de comercialização utilizados para a aquisição de livros eletrônicos para bibliotecas do Distrito Federal”. Durante as entrevistas as bibliotecas foram questionadas sobre os modelos de comercialização, e todos os detalhes foram descritos e comentados na análise de dados. As bibliotecas da entrevista compraram de editoras, agregadores e distribuidores. A seleção dos livros foi feita por pacote ou por título. Os modelos de negócio utilizados foram assinatura e acesso perpétuo. O acesso aos livros era ilimitado, múltiplo ou de um usuário por vez. O meio de acesso aos livros era online ou por download.

O primeiro objetivo específico era "1) Identificar os principais termos relacionados aos livros eletrônicos, bem como suas conceituações”. Esse objetivo específico foi alcançado com a revisão de literatura.

O livro eletrônico, que também pode ser chamado de livro digital ou e-book, teve as suas várias definições analisadas. Os formatos, aparelhos e programas para ler os livros eletrônicos foram apresentados.

O segundo objetivo, “2) Identificar e analisar os modelos existentes de comercialização de livros eletrônicos para bibliotecas", também foi alcançado com a revisão de literatura. Para identificar os modelos existentes, quase todos os textos utilizados estavam em inglês, já que ainda existe muito pouco material sobre o assunto em português.

O objetivo específico "3) Identificar as bibliotecas que utilizam o livro eletrônico no DF" foi alcançado com a pesquisa. A primeira parte da identificação das bibliotecas que utilizam livros eletrônicos foi feita por e-mail, e depois foi confirmada por telefone. Esse objetivo foi necessário para que o seguinte pudesse ser alcançado.

O universo identificado pela pesquisa por e-mail incluía 24 bibliotecas que já haviam comprado ou que pretendiam comprar livros eletrônicos. Mas, dessas bibliotecas, nove não compraram livros eletrônicos, em três a compra é feita por uma sede que não fica em Brasília, e em duas não foi possível marcar a entrevista. Portanto, a entrevista foi feita em dez bibliotecas, de tamanhos e perfis variados.

O último objetivo específico era "4) Analisar os modelos de negócios utilizados para a aquisição de livros eletrônicos para bibliotecas do DF, bem como as razões dessas escolhas". A análise dos modelos foi feita a partir das respostas das entrevistas, e seu resumo pode ser visto nos quadros 55 e 56. 
Para analisar os modelos de negócios de livros eletrônicos a pesquisa seria mais completa se tivesse sido feita diretamente com os vendedores. O que se buscou aqui foi analisar esses modelos sob o ponto de vista das bibliotecas, o que permite a avaliação crítica do que é oferecido. A visão dos vendedores é ideal, então mesmo que eles possam responder com mais exatidão sobre o funcionamento dos modelos, dificilmente a pesquisa apresentaria as falhas dos modelos, as dificuldades encontradas no processo de compra, as necessidades reais das bibliotecas e como elas se relacionam com o que é oferecido. Além disso, provavelmente seria mais difícil obter informações dos vendedores que não se interessariam em investir seu tempo em uma pesquisa que não lhes trouxesse nenhum retorno comercial.

Nesse levantamento foi possível observar que muitas bibliotecas não compram livros eletrônicos por falta de recursos, e outras porque acham que não vale a pena. Os produtores de bases de dados precisam conhecer e estudar mais os seus clientes para entender as suas necessidades e oferecer um produto que os agrade. Não existe um modelo ideal para todos pois cada biblioteca tem o seu perfil, as suas especificidades e necessidades próprias. Por isso é tão importante que os vendedores ofereçam modelos diferenciados, para que seja possível se adequar também aos orçamentos de pequenas e grandes bibliotecas.

Para conseguir comprar todos os livros eletrônicos que deseja, muitas vezes as bibliotecas precisam adquirir de vendedores diferentes. E mesmo que a biblioteca possua recursos para pagar um serviço de descoberta, o acesso aos livros será feito em plataformas diferentes.

Outro ponto interessante é que na venda dos livros eletrônicos, são os vendedores que procuram as bibliotecas. E quando as bibliotecas tentam contato com os vendedores, têm dificuldade em encontrar informações sobre o assunto.

No que concerne aos formatos, a decisão vai além de saber se o PDF ou o EPUB são o melhor formato para os livros eletrônicos. Em muitos casos o acesso é apenas online, e os livros estão em HTML ou em outro formato feito para a exibição de páginas da Internet, que é pouco adequado para os livros eletrônicos, mas mesmo assim parece ser o mais utilizado.

Os modelos de comercialização de livros eletrônicos da pesquisa são tão variados quanto os da revisão de literatura. Foram encontradas, inclusive, novas possibilidades, como a limitação de acesso à base de dados pelo número de licenças compradas.

Tanto as bibliotecas grandes como as pequenas conseguiram comprar livros eletrônicos, sendo que cada uma utilizou modelos diferentes. Mas as bibliotecas pequenas tiveram menos opções de escolha para realizar a compra. As duas menores bibliotecas da pesquisa, A e G, 
compraram seus livros por título e com distribuidores, e tiveram muitas respostas iguais nas entrevistas.

No quadro 55, os modelos de negócios são descritos de acordo com as divisões propostas na revisão de literatura.

Quadro 55 - Os modelos de negócios classificados de acordo com as divisões da revisão de literatura

\begin{tabular}{|c|c|c|c|c|c|c|}
\hline $\begin{array}{l}\text { Empresas } \\
\text { nacionais }\end{array}$ & Biblioteca & Tipo & Seleção & $\begin{array}{l}\text { Modelo de } \\
\text { negócio }\end{array}$ & Acesso & Meio \\
\hline Fórum & $\mathrm{D}, \mathrm{H}, \mathrm{I}$ & Editora & Pacote. & $\begin{array}{l}\text { Acesso } \\
\text { perpétuo, } \\
\text { Assinatura }\end{array}$ & Ilimitado & Online \\
\hline Livraria Cultura & $\mathrm{A}$ & $\begin{array}{l}\text { Livraria } \\
\text { (Distribuidor) }\end{array}$ & Título. & Acesso perpétuo & Múltiplo & Download \\
\hline Livreiro & $\mathrm{G}$ & Distribuidor & Título. & Acesso perpétuo & Um por vez & Download \\
\hline $\begin{array}{l}\text { Minha } \\
\text { Biblioteca }\end{array}$ & $\mathrm{F}$ & Agregador & Pacote. & Assinatura anual & Ilimitado & Online \\
\hline $\begin{array}{l}\text { Revista dos } \\
\text { Tribunais }\end{array}$ & $\mathrm{H}$ & Editora & Pacote. & Assinatura anual & Ilimitado & Online \\
\hline Saraiva & $\mathrm{J}$ & Editora & Pacote. & $\begin{array}{l}\text { Assinatura } \\
\text { semestral }\end{array}$ & Ilimitado & Online \\
\hline \multicolumn{7}{|l|}{$\begin{array}{l}\text { Empresas } \\
\text { estrangeiras }\end{array}$} \\
\hline CABI & $\mathrm{E}$ & Editora & Pacote. & $\begin{array}{l}\text { Acesso } \\
\text { perpétuo, } \\
\text { Assinatura }\end{array}$ & Ilimitado & $\begin{array}{l}\text { Online e } \\
\text { download }\end{array}$ \\
\hline Ebrary & $\mathrm{B}, \mathrm{H}$ & Agregador & Pacote. & $\begin{array}{l}\text { Acesso } \\
\text { perpétuo, } \\
\text { Assinatura }\end{array}$ & Ilimitado & $\begin{array}{l}\text { Online e } \\
\text { download }\end{array}$ \\
\hline Elsevier & $\mathrm{C}, \mathrm{E}$ & Editora & Pacote. & Assinatura & Ilimitado & $\begin{array}{l}\text { Online e } \\
\text { download }\end{array}$ \\
\hline McGraw-Hill & $\mathrm{C}$ & Editora & Pacote. & Assinatura & Ilimitado & Online \\
\hline $\begin{array}{l}\text { Pearson } \\
\text { (EBSCO) }\end{array}$ & $\mathrm{F}, \mathrm{J}$ & Agregador & Pacote. & Assinatura anual & Ilimitado & Online \\
\hline Safari Books & $\mathrm{H}$ & Agregador & Pacote. & Assinatura & Ilimitado & $\begin{array}{l}\text { Online e } \\
\text { download }\end{array}$ \\
\hline Springer & $\mathrm{E}$ & Editora & Pacote. & $\begin{array}{l}\text { Acesso } \\
\text { perpétuo, } \\
\text { Assinatura }\end{array}$ & Ilimitado & $\begin{array}{l}\text { Online e } \\
\text { download }\end{array}$ \\
\hline V-lex & $\mathrm{J}$ & Agregador & Pacote. & Assinatura & Ilimitado & Online \\
\hline
\end{tabular}

Fonte: Autoria própria.

Os vários segmentos do negócio do livro eletrônico foram analisados na revisão de literatura. As divisões da revisão de literatura puderam ser observadas na pesquisa. Os vendedores são diversificados, isto é, editoras, agregadores e distribuidores, e suas características correspondem ao que foi descrito na revisão de literatura.

A seleção dos livros eletrônicos normalmente é feita por título ou por pacotes, divididos por assunto ou ano de publicação dos livros. O que não havia sido comentado na revisão de literatura é que às vezes o vendedor oferece apenas a base de dados completa, e não há seleção alguma, nem por título nem por pacotes. O plano de aprovação, o firm order e o standing order mencionados por Morris e Sibert (2011) não foram utilizados pelas bibliotecas respondentes. 
Sobre os modelos de negócio, o empréstimo de curto prazo e a aquisição orientada pelo usuário estão presentes na literatura, mas não foram adotados por nenhuma biblioteca da pesquisa. As bibliotecas compraram apenas por acesso perpétuo e assinatura anual ou semestral.

Os modelos de acesso da literatura falam em limitação do número de acessos por livro. Nessa pesquisa a limitação não era para cada livro, mas sim para toda a plataforma. As bibliotecas A e $\mathrm{G}$ possuem limitações por livro porque eles estavam atrelados ao suporte. Para todas as outras bibliotecas, o acesso por livro era ilimitado.

Os limites de acesso por plataforma são um aspecto novo, que não foi abordado na revisão de literatura. $\mathrm{O}$ limite de acesso por plataforma foi relatado pelas bibliotecas $\mathrm{C}, \mathrm{H}$ e J, para os vendedores McGraw-Hill, Safari e Saraiva, respectivamente. As bibliotecas C e J pagam por um número determinado de acessos simultâneos. Na biblioteca $\mathrm{H}$ o modelo é diferente, pois ela paga por um número determinado de licenças, e cada uma delas é atribuída a um usuário, não importando o momento em que eles acessam a base.

O meio de acesso, que pode ser online ou por download, corresponde ao que foi observado na revisão de literatura. A diferença é que, quando o acesso é por download, poucas bibliotecas utilizaram o empréstimo eletrônico com devolução automática. Em muitos casos o download do livro era feito por capítulos, que é como os livros estavam divididos para leitura. Dificilmente o usuário tinha a opção de fazer o download de todos os capítulos.

Assim, as divisões da revisão de literatura puderam ser observadas nas bibliotecas da pesquisa, mas a realidade se mostrou ainda mais complexa. Por isso foi feito o quadro 56, que descreve os modelos livremente, destacando o diferencial de cada um.

O quadro 56, apesar de não ter sido parte do formulário da entrevista, busca apresentar as principais caraterísticas dos modelos adquiridos por cada biblioteca. Nele, é possível observar toda a diversidade dos modelos, que não podem ser encaixados em nenhum padrão. As divisões adotadas na revisão de literatura foram feitas com o intuito de tentar explicar essa diversidade com mais clareza, mas ainda assim não conseguem abordar todos os aspectos da realidade. 
Quadro 56 - Funcionamento dos modelos de negócios

\begin{tabular}{|c|c|c|}
\hline \multicolumn{3}{|r|}{ Funcionamento do modelo escolhido } \\
\hline Empresas nacionais & $\begin{array}{l}\text { Biblio- } \\
\text { teca }\end{array}$ & Funcionamento \\
\hline \multirow[t]{3}{*}{ Fórum } & $\mathrm{D}$ & $\begin{array}{l}\text { A biblioteca possui acesso perpétuo e os arquivos dos livros comprados. } \\
\text { Esses livros são atualizados durante o período de vigência da compra. É } \\
\text { como uma assinatura na qual a biblioteca permanece com os arquivos. }\end{array}$ \\
\hline & $\mathrm{H}$ & $\begin{array}{l}\text { Assinatura de pacotes com atualização das edições. Mas devido ao } \\
\text { período de renovação da biblioteca, logo antes do lançamento de novas } \\
\text { coleções, ela passa um ano sem os títulos novos. O acesso é apenas } \\
\text { online. }\end{array}$ \\
\hline & I & $\begin{array}{l}\text { A biblioteca assinou a base. Os livros são atualizados automaticamente } \\
\text { durante a assinatura, e quando ela não é renovada a biblioteca não perde } \\
\text { o acesso ao que já pagou. }\end{array}$ \\
\hline Livraria Cultura & $\mathrm{A}$ & $\begin{array}{l}\text { A biblioteca comprou um aparelho Kobo e alguns livros eletrônicos, que } \\
\text { podem ser acessados apenas nele ou em alguns dispositivos dos usuários } \\
\text { nos quais a biblioteca colocou a sua senha de acesso. }\end{array}$ \\
\hline Livreiro & $\mathrm{G}$ & $\begin{array}{l}\text { Para cada livro comprado a biblioteca recebe instruções que são } \\
\text { repassadas para a área que pediu o livro. Eles fazem o download e o livro } \\
\text { fica atrelado a um único tablet, que apenas pode ser utilizado por quem } \\
\text { trabalha naquela área. }\end{array}$ \\
\hline Minha Biblioteca & $\mathrm{F}$ & A biblioteca assina a base inteira, com acesso ilimitado. \\
\hline $\begin{array}{l}\text { Revista dos } \\
\text { Tribunais }\end{array}$ & $\mathrm{H}$ & Assinatura de pacotes. $\mathrm{O}$ acesso é apenas online. \\
\hline Saraiva & $\mathrm{J}$ & $\begin{array}{l}\text { A assinatura é renovada a cada seis meses e o acesso é apenas online, } \\
\text { com um limite de } 3.600 \text { usuários simultâneos. A seleção é feita por } \\
\text { pacotes de } 200 \text { livros que podem ser escolhidos pela biblioteca. As } \\
\text { edições são atualizadas automaticamente. }\end{array}$ \\
\hline \multicolumn{3}{|l|}{$\begin{array}{l}\text { Empresas } \\
\text { estrangeiras }\end{array}$} \\
\hline CABI & $\mathrm{E}$ & A editora forneceu o backup dos livros em CD. \\
\hline \multirow[t]{2}{*}{ Ebrary } & $\mathrm{B}$ & $\begin{array}{l}\text { Assinatura de pacotes com acesso ilimitado, inclusive para usuários } \\
\text { externos na área da biblioteca. }\end{array}$ \\
\hline & $\mathrm{H}$ & $\begin{array}{l}\text { Assinatura de pacotes. É possível fazer o download, com empréstimo de } \\
15 \text { dias. }\end{array}$ \\
\hline \multirow[t]{2}{*}{ Elsevier } & $\mathrm{C}$ & $\begin{array}{l}\text { Possui uma base de medicina (ClinicalKey) que é assinada com acesso } \\
\text { ilimitado, e os livros que não estão na base podem ser comprados. }\end{array}$ \\
\hline & $\mathrm{E}$ & $\begin{array}{l}\text { Assinatura de pacotes com acesso apenas durante o período de vigência. } \\
\text { Alguns títulos são de acesso perpétuo. }\end{array}$ \\
\hline McGraw-Hill & $\mathrm{C}$ & $\begin{array}{l}\text { Os livros são assinados e há um limite de } 15 \text { acessos simultâneos à } \\
\text { plataforma. }\end{array}$ \\
\hline \multirow[t]{2}{*}{ Pearson (EBSCO) } & $\mathrm{F}$ & A biblioteca assina a base inteira, com acesso ilimitado. \\
\hline & $\mathrm{J}$ & $\begin{array}{l}\text { Assinatura de pacotes fechados. O acesso é apenas online. As edições } \\
\text { são atualizadas automaticamente. }\end{array}$ \\
\hline Safari Books & $\mathrm{H}$ & $\begin{array}{l}\text { Tem um limite de licenças, mas o acesso aos livros é ilimitado. Nós } \\
\text { pagamos por licenca, então temos } 120 \text { licencas. }\end{array}$ \\
\hline Springer & $\mathrm{E}$ & $\begin{array}{l}\text { Assinatura de pacotes com acesso apenas durante o período de vigência. } \\
\text { Alguns títulos são de acesso perpétuo. }\end{array}$ \\
\hline V-lex & $\mathrm{J}$ & $\begin{array}{l}\text { Assinatura de pacotes. O acesso é apenas online. As edições são } \\
\text { atualizadas automaticamente. }\end{array}$ \\
\hline
\end{tabular}

Fonte: Autoria própria. 
As respostas das questões 26, 30 e 54 mostram que muitas vezes os modelos de negócios (acesso perpétuo ou assinatura), de seleção (título ou pacote) e de acesso (ilimitado ou para um número determinado de usuários) são únicos para cada vendedor. Assim, as bibliotecas não estão livres para escolher o que se adapta melhor às necessidades dos seus usuários ou ao seu orçamento. Por exemplo, se uma biblioteca pequena decide comprar livros de uma editora que possui a sua própria plataforma e que vende por exclusividade apenas pacotes de acesso ilimitado, ela não poderá adquirir esses livros em formato eletrônico pois isso excederia muito o valor que ela pode gastar.

Foi o que aconteceu com a biblioteca A, que é pequena e viu na compra com um distribuidor a oportunidade de adquirir por título para oferecer livros eletrônicos aos seus usuários. Pelo fato de ser pequena, essa biblioteca não poderia oferecer qualquer livro de qualquer editora para os seus usuários, o que é algo inconcebível no mercado de livros impressos, onde qualquer um pode comprar qualquer livro, desde que possa pagar por ele.

"Os livros eletrônicos estão estagnados em sistemas fechados e enfadonhos, enquanto os livros impressos são compartilháveis, bonitos e duráveis. O que vem a seguir?" (MOOD, 2015).

O subtítulo do texto de Mood (2015) resume a situação atual dos livros eletrônicos em geral, não apenas para bibliotecas. Com esta pesquisa foi possível perceber que o principal problema dos livros eletrônicos não está neles, mas na falta de inovação que os cerca. A maioria das bibliotecas relatou problemas com os modelos de negócios e com as plataformas e suas funcionalidades, mas não com os livros. Falta criatividade para agradar por parte daqueles que vendem o livro eletrônico. Temos que pensar: o que Steve Jobs faria se quisesse vender um livro? Como agradar aos leitores? Aí sim, o livro eletrônico teria uma oportunidade realmente competitiva de concorrer com o seu velho irmão impresso.

As sugestões de pesquisa que podem ser feitas a partir dessa dissertação são estudar melhor a questão das bibliotecas universitárias em relação à avaliação do MEC no que se refere à aceitação dos livros eletrônicos, e refazer a mesma pesquisa em outro Estado ou daqui a uns dois anos, em 2017, para ver o que mudou no cenário dos livros eletrônicos. O MEC, na sua avaliação das bibliotecas universitárias, ainda não possui critérios claros para a aceitação dos livros eletrônicos como parte da quantidade de exemplares que a biblioteca deve ter para a aprovação de um curso. Outra sugestão de pesquisa é avaliar como os modelos de comercialização de livros eletrônicos por assinatura, sem a permanência dos livros com a biblioteca, afeta a preservação da memória histórica. 


\section{REFERÊNCIAS BIBLIGRÁFICAS}

ADOBE. FAQ. 2015. Disponível em: <http://www.adobe.com/br/solutions/ebook/digitaleditions/faq.html>. Acesso em: 12 jan. 2015.

ALBANESE, Andrew. Penguin Expands E-books in Libraries. Publishers Weekly, [S. 1.], 26 set. 2013. Disponível em: <www.publishersweekly.com/pw/by-topic/digital/content-and-ebooks/article/59255-penguin-expands-e-books-in-libraries-adds-friction-to-kindlelends.html>. Acesso em: 24 set. 2014.

ALBITZ, Becky; BRENNAN, David. Licensing of E-Books. In: KAPLAN, Richard. Building and managing e-book collections: a how-to-do-it manual for librarians. Chicago: ALA, 2012. Cap. 6, p. 75-84.

ALTARES, Guillermo. O livro de papel resiste à avalanche digital: apesar das previsões, o $e$ book ainda é minoritário no mercado editorial. El País, 02 nov. 2015. Disponível em: < http://brasil.elpais.com/brasil/2015/10/23/cultura/1445623004_054856.html>. Acesso em: 09 nov. 2015.

AMERICAN LIBRARY ASSOCIATION. Ebook Business Models for Public Libraries, 8 ago. 2012. Disponível em: <http://www.ala.org/transforminglibraries/ebook-business-modelspublic-libraries>. Acesso em: 15 ago. 2013.

APPLE. iBooks. 2015. Disponível em: <http://www.apple.com/br/ibooks/>. Acesso em: 12 jan. 2015.

ARDITO, S. Electronic books: to "E" or not to "E"; that is the question. Searcher: the Magazine for Database Professionals, Medford, v. 8, n. 4, abr. 2000. Disponível em: <http://www.infotoday.com/searcher/apr00/ardito.htm>. Acesso em: 29 out. 2014.

A VOZ DA SERRA. Livro eletrônico ou de papel? No Brasil e outros países, jovens leitores dão preferência aos livros impressos. A Voz da Serra, 07 nov. 2015. Disponível em: <http://avozdaserra.com.br/noticias/livro-eletronico-ou-de-papel>. Acesso em: 09 nov. 2015.

BABBIE, Earl. Métodos de pesquisas de survey. Belo Horizonte: UFMG, 1999. 519 p.

BARROS, Moreno. Curso e-Books para bibliotecas: uma introdução ao universo dos livros eletrônicos. ExtraLibris, 2014. Disponível em: <http://extralibris.org/curso/introducao-aos-ebooks-para-bibliotecas/>. Acesso em: 07 jan. 2015.

BHATTACHERJEE, Anol. Social Science Research: Principles, Methods, and Practices. Tampa Bay: University of South Florida, 2012.

BIBLIOTECAS PÚBLICAS DE CATALUÑA. Proyecto 10X10: Encuentros de los editores con los bibliotecarios. Página da Internet. Publicado em: 24 jul. 2013. Disponível em: <http://www20.gencat.cat/portal/site/Biblioteques/menuitem.690b4e2d7721b5b009671410b0 c0e1a0/?vgnextoid=ded81e1f0f090110VgnVCM1000000b0c1e0aRCRD\&vgnextchannel=de d81e1f0f090110VgnVCM1000000b0c1e0aRCRD\&vgnextfmt=detall\&contentid=95f7affe4af 00410VgnVCM1000008d0c1e0aRCRD\&newLang=es_ES>. Acesso em: 02 set. 2014. 
BRASIL. Lei $\mathrm{n}^{\circ}$ 8.078, de 11 de setembro de 1990. Código de defesa do consumidor. Disponível em: <http://www.planalto.gov.br/ccivil_03/Leis/L8078.htm>. Acesso em: $15 \mathrm{dez}$. 2015.

BRASIL. Lei n ${ }^{\circ}$ 9.610, de 19 de fevereiro de 1998. Lei do direito autoral. Disponível em: <http://www.planalto.gov.br/ccivil_03/leis/19610.htm>. Acesso em: 23 dez. 2014.

BUENO, Katiussa Nunes. Relatos de experiência na aquisição de $e$-books e base de dados. In: WEBINAR IFLA LAC 2015: Nuevos modelos de contratos para la adquisición de contenido electrónico. Seminário online realizado no dia 28 de maio de 2015. Disponível em: < https://plus.google.com/events/cdtsc4mcalvnqhielcs3psdb21o >. Acesso em: 30 out. 2015.

CHARTERED INSTITUTE OF LIBRARY AND INFORMATION PROFESSIONALS. Ebook acquisition and lending in public libraries. Versão 4, out. 2014. Disponível em: <http://www.cilip.org.uk/cilip/advocacy-campaigns-awards/advocacycampaigns/ebooks/briefings-and-resources/ebooks-and-publi-0>. Acesso em: 22 jan. 2015.

COLMENERO NIÑO, María Begoña. En cualquier momento y en cualquier lugar: la biblioteca electrónica del Instituto Cervantes. In: CONGRESSO BRASILEIRO DE BIBLIOTECONOMIA, DOCUMENTAÇÃO E CIÊNCIA DA INFORMAÇÃO, 25., 2013, Florianópolis. Anais... Disponível em: <http://portal.febab.org.br/anais/article/view/1400>. Acesso em: 14 dez. 2015.

CONGRESSO INTERNACIONAL CBL DO LIVRO DIGITAL, 5., 2014, São Paulo. Disponível em: < http://www.congressodolivrodigital.com.br/>. Acesso em: 01 jul. 2014.

CONNAWAY, Lynn Silipigni; POWELL, Ronald R. Basic research methods for librarians. Santa Barbara: Libraries Unlimited, 2010.

CORROTO, Paula. Ebiblio: un proyecto público de préstamo de ebooks con luces y muchas sombras. El Diario. Publicado em: 17 set. 2014. Disponível em:

<http://www.eldiario.es/turing/industria_editorial/Ebiblio-proyecto-publico-prestamosombras_0_303420112.html>. Acesso em: 20 jan. 2015.

CRESWELL, John W. Investigação qualitativa e projeto de pesquisa: escolhendo entre cinco abordagens. Porto Alegre: Penso, 2014.

CRESWELL, John W. Projeto de Pesquisa: Métodos Qualitativo, Quantitativo e Misto. 3. ed. Porto Alegre, RS: Artmed, 2010.

CUNHA, Murilo Bastos da; CAVALCANTI, Cordélia R. Dicionário de biblioteconomia e arquivologia. Brasília: Briquet de Lemos, 2008.

DARNTON, Robert. A questão dos livros: passado, presente e futuro. São Paulo: Companhia das Letras, 2010.

DOUCETTE, Joanne; LEWONTIN, Amy. Selecting E-Books. In: KAPLAN, Richard. Building and managing e-book collections: a how-to-do-it manual for librarians. Chicago: ALA, 2012. cap. 5, p. 51-74. 
ESPANHA. Real Decreto legislativo 1/1996 de 12 de abril de 1996. Lei de Propriedade Intelectual. Disponível em: <http://www.mecd.gob.es/cultura-mecd/dms/mecd/cultura$\mathrm{mecd} /$ areas-cultura/propiedad-intelectual/la-propiedad-intelectual/preguntas-masfrecuentes/registro/TRLPropiedad_Intelectual.pdf>. Acesso em: 23 dez. 2014.

\section{EUROPEAN BUREAU OF LIBRARY INFORMATION AND DOCUMENTATION}

ASSOCIATIONS. The Right to eRead Campaign. Página da Internet. Disponível em: < http://www.eblida.org/e-read/the-campaign.html>. Acesso em: 01 out. 2014.

FERNANDES, Leila. Entrevista realizada em 11 de outubro de 2015. Brasília, 2015.

GRANJEIRO, José Wilson; CARDOSO, Rodrigo. Direito administrativo simplificado. Brasília: Gran Cursos, 2013.

GREGORY, V. L. Collection development and management for 21st century library collections: an introduction. New York: Neal-Schuman, 2011.

GRIGSON, A. An introduction to e-book business models and suppliers. In: PRICE, K.; HAVERGAL, V. E-books in libraries: a practical guide. London: Facet, 2011. cap. 2, p. 1936.

INOUYE, Alan S. Simon \& Schuster expands library ebook lending program to universal access. American Libraries, Publicado em: 26 jun. 2014. Disponível em: $<$ http://www.americanlibrariesmagazine.org/blog/simon-schuster-expands-its-library-ebookpilot-nationwide>. Acesso em: 02 set. 2014.

INTERNATIONAL FEDERATION OF LIBRARY ASSOCIATIONS AND INSTITUTIONS. IFLA 2014 eLending Background Paper. Disponível em: < http://www.ifla.org/node/8851>. Acesso em: 01 out. 2014.

KAPLAN, Richard. Building and managing e-book collections: a how-to-do-it manual for librarians. Chicago: ALA, 2012.

KOH, HyunSeung; HERRING, Susan C. Ebooks, E-readers, and Ebook device design. In: KHOSROW-POUR, Mehdi. Encyclopedia of Information Science and Technology. 3rd ed. EUA: IGI, 2014. cap. 221, p. 2.278-2.287. Disponível em:

<http://books.google.com.br/books?id=MJd_BAAAQBAJ\&printsec=frontcover\&hl=pt-BR>. Acesso em: 29 nov. 2014.

KONRAD, Katherine. Old Habits in a New World? E-book management techniques at an academic library. 2013. 64 p. Dissertação (Mestrado em Biblioteconomia e Ciência da Informação) - Escola Sueca de Biblioteconomia e Ciência da Informação, 2013.

LINS, Greyciane Souza. Curso de introdução à criação de livros digitais. Brasília: Universidade de Brasília, 18 mar. 2014.

MARCIAL, Cristine Coutinho (Org.); GUIMARÃES, Tatiara Paranhos (Org.). Guia de bibliotecas da 1a Região: Distrito Federal, Goiás, Mato Grosso e Mato Grosso do Sul. Brasília: Senado Federal, Biblioteca Acadêmico Luiz Viana Filho, 2008. 
MARINS, Roberta Penha e Silva. Entrevista realizada em 25 de outubro de 2015. Brasília, 2015 .

MARTÍNEZ DE SOUSA, José. Pequeña historia del libro. 4. ed. rev. e ampl. Gijón: Trea, 2010.

MENDONÇA, Felipe Marra. O papel resiste: Cresce o número de livrarias nos EUA, enquanto recua a venda de e-books. Carta Capital, 15 out. 2015. Disponível em:

$<$ http://www.cartacapital.com.br/revista/870/o-papel-resiste-

9893.html?utm_content=buffer817ee\&utm_medium=social\&utm_source=twitter.com\&utm_c ampaign=buffer $>$. Acesso em: 09 nov. 2015.

MOOD, Craig. Will digital books ever replace print? Aeon. Publicado em 01 out. 2015. Disponível em: < http://aeon.co/magazine/technology/why-have-digital-books-stoppedevolving/>. Acesso em: 16 out. 2015.

MORRIS, C.; SIBERT, L. Acquiring e-books. In: POLANKA, S. (Ed.). No shelf required: e books in libraries. Chicago: American Libraries Association, 2011. cap. 6, p. 95-124.

ONLEIHE. Fragen rund um die Onleihe. Disponível em: < http://www.onleihe.net/fragenrund-um-die-onleihe.html >. Acesso em: 30 set. 2014.

PINHEIRO, Carlos. Dicionário do e-book. [S.1.]: Ler Ebooks, 2011. Disponível em: $<$ https://lerebooks.files.wordpress.com/2011/12/dicionc3a1rio-do-ebook.pdf >. Acesso em: 10 jul. 2015.

POLANKA, Sue. No Shelf Required 2: Use and Management of Electronic Books. Chicago: American Library Association, 2012.

PROCÓPIO, Ednei. Construindo uma biblioteca digital. São Paulo: EI Edições Inteligentes, 2004.

PROJECT GUTENBERG. Página da Internet. Disponível em: <http://www.gutenberg.org/> . Acesso em: 01 jul. 2014.

REID, Calvin. Penguin Severs Ties with OverDrive. Publishers Weekly, [S.1.], 09 fev. 2012. Disponível em: <http://www.publishersweekly.com/pw/by-topic/digital/content-and-ebooks/article/50579-penguin-severs-ties-with-overdrive.html>. Acesso em: 24 set. 2014.

REIS, Juliani Menezes dos; ROZADOS, Helen Beatriz Frota. O livro digital e a tríade bibliotecas, mercado editorial e governo. In: SEMINÁRIO NACIONAL DE BIBLIOTECAS UNIVERSITÁRIAS, 18., 2014, Belo Horizonte. Anais... Disponível em: $<$ https://www.bu.ufmg.br/snbu2014/wp-content/uploads/trabalhos/581-2149.pdf >. Acesso em: 09 jul. 2015.

RESENDE, Janaína Barcelos. Avaliação de Ebook 2014. Entrevista realizada em 8 de setembro de 2014. Brasília, 2014.

RONCEVIC, Mirela. E-book Platforms for Libraries. Library Technology Reports, Chicago, v. 49, n. 3, abr. 2013. 
RUBEL, José. Termo de referência: Orientações para redação. Curitiba: Instituto de Terras, Cartografia e Geociências, 2007. Disponível em: <

http://www.itcg.pr.gov.br/arquivos/File/Estrutura_TR_01112007.pdf>. Acesso em: 12 out. 2015.

SANTANA, Anderson de. Modelos de contratos para conteúdos eletrônicos. In: WEBINAR IFLA LAC 2015: Nuevos modelos de contratos para la adquisición de contenido electrónico. Seminário online realizado no dia 28 de maio de 2015. Disponível em: < https://plus.google.com/events/cdtsc4mcalvnqhielcs3psdb21o >. Acesso em: 30 out. 2015

SEKARAN, Uma. Research methods for business: A skill-building approach. 4. ed. Chichester: Wiley, 2003.

SERRA, Liliana Giusti. Livro digital e as bibliotecas. Rio de Janeiro: FGV, 2014.

SERRA, Liliana Giusti; SILVA, José Fernando Modesto da. Licenciamento de livros eletrônicos e o modelo de negócios PDA (Patron Driven Acquisition) In: SEMINÁRIO NACIONAL DE BIBLIOTECAS UNIVERSITÁRIAS, 18., 2014, Belo Horizonte. Anais... Disponível em: < https://www.bu.ufmg.br/snbu2014/wp-content/uploads/trabalhos/792084.pdf >. Acesso em: 08 nov. 2015.

SILVERMAN, D. Interpretação de dados qualitativos: Métodos para análise de entrevistas, textos e interações. 3. ed. Porto Alegre: Artmed, 2009.

STAKE, Robert E. Pesquisa Qualitativa: estudando como as coisas funcionam. Porto Alegre: Penso, 2011.

TAMMARO, Anna Maria; SALARELLI, Alberto. A biblioteca digital. Brasília: Briquet de Lemos, 2008.

TOUTAIN, Lídia Maria Batista Brandão. Biblioteca digital: definição de termos. In: MARCONDES, C. H. et al. Bibliotecas digitais: Saberes e práticas. Salvador: EDUFBA, 2006.

VASILEIOU, Magdalini; ROWLEY, Jennifer; HARTLEY, Richard. The e-book management framework: the management of e-books in academic libraries and its challenges. Library $\boldsymbol{\&}$ Information Science Research, London, v. 34, n. 4, p. 282-291, out. 2012. Disponível em: <http://www.sciencedirect.com/science/journal/07408188/34>. Acesso em: 10 set. 2014.

VASSILIOU, Magdalini; ROWLEY, Jennifer. Progressing the definition of "e-book".

Library Hi Tech, [S.1.], v. 26, n. 3, p. 355-368, 2008. Disponível em:

<http://www.emeraldinsight.com/journals.htm?articleid=1745069>. Acesso em: 04 nov. 2014.

VERGUEIRO, Waldomiro. Seleção de materiais de informação: princípios e técnicas. 3. ed. Brasília: Briquet de Lemos, 2010.

WALTERS, William H. E-books in Academic Libraries: Challenges for Acquisition and Collection Management. Libraries and the Academy, [S.1.], v. 13, n. 2, p. 187-211, 2013. 
Disponível em:

$<$ https://muse.jhu.edu/journals/portal_libraries_and_the_academy/toc/pla.13.2.html $>$. Acesso em: 08 ago. 2013.

WEBOPEDIA. Dark archive. 2015. Disponível em:

<http://www.webopedia.com/TERM/D/dark_archive.html>. Acesso em: 30 out. 2015.

WIKIPEDIA. Copyleft. 2014a. Disponível em: <http://pt.wikipedia.org/wiki/Copyleft>. Acesso em: 23 dez. 2014.

WIKIPEDIA. Creative Commons. 2014b. Disponível em:

<http://pt.wikipedia.org/wiki/Creative_Commons>. Acesso em: 23 dez. 2014.

WIKIPEDIA. Electronic paper. 2014c. Disponível em:

<http://en.wikipedia.org/wiki/Electronic_paper>. Acesso em: 29 nov. 2014. 
Apêndice A - Empresas e organizações citadas no trabalho

ACCUMON - Accurate Communications for Publishers. http://www.accucoms.com/

ACLS Humanities Ebook. http://www.humanitiesebook.org/

Amazon. http://www.amazon.com.br/

Árvore de Livros. http://www.arvoredelivros.com.br/

Biblioteca Virtual Universitária. http://www.bvirtual.com.br/

Biblioteca Xeriph. http://www.xeriph.com.br/

CABI. http://www.cabi.org/cabebooks

Cambridge. http://ebooks.cambridge.org/

Cengage. http://www.cengage.com.br/c-dls/e-books/

ClinicalKey. https://www.clinicalkey.com/

CLOCKSS. https://www.clockss.org

De Gruyter. http://www.degruyter.com/

DotLib. http://www.dotlib.com.br/

EBL. http://www.eblib.com/

Ebrary (ProQuest). http://www.ebrary.com/corp/

EBSCO. http://www.ebscohost.com/ebooks

EDS (EBSCO). https://www.ebscohost.com/discovery

Elsevier. http://www.elsevier.com.br/digital/

Fórum. http://www.bidforum.com.br

Hachette. http://www.hachettebookgroup.com/

HarperCollins. http://www.harpercollins.com/

HathiTrust. https://www.hathitrust.org/

IOP Publishing. http://ioppublishing.org/publications/books

ITMS Group. http://www.itmsgroup.net/

Libranda. http://www.libranda.com/

Livraria Cultura. http://www.livrariacultura.com.br/

LOCKSS. http://www.lockss.org/

Macmillan. www.macmillan.com

McGraw-Hill. www.mcgraw-hill.com/

Mienciclo Ebooks. http://www.mienciclo.es/

Minha Biblioteca. http://www.minhabiblioteca.com.br/

Nuvem de livros. https://www.nuvemdelivros.com.br/

OverDrive. https://www.overdrive.com/

Pearson. https://br.pearson.com/

Palgrave. http://www.palgraveconnect.com/ 
Penguin. http://www.penguin.com/

Portico. http://www.portico.org/digital-preservation/

Primo (Ex Libris). http://www.exl.com.br/primo.htm

Proquest. http://www.proquest.com/

Random House. http://www.randomhouse.com/

Rede Cariniana. http://cariniana.ibict.br/

Revista dos Tribunais. http://www.livrariart.com.br/

Safari. http://www.safaribooksonline.com/

Saraiva. http://hotsites.editorasaraiva.com.br/bibliografiadigital/home.html

Simon \& Schuster. http://www.simonandschuster.com/

Simplíssimo. http://www.simplissimo.com.br/

Springer. http://link.springer.com/

Summon (Proquest). http://www.proquest.com/products-services/The-Summon-Service.html

V-lex. http://vlex.com.br/

VuFind. http://vufind-org.github.io/vufind/

Wiley. http://onlinelibrary.wiley.com/ 


\section{Apêndice B - Primeira versão do formulário da entrevista}

\section{A) DADOS DA BIBLIOTECA}

1. Nome da biblioteca:

2. Órgão vinculado:

3. Número de funcionários:

4. Quantidade de bibliotecários:

5. Tipo de biblioteca (Universitária, pública, especializada etc.):

6. Acervo:

7. Sistema de automação:

8. Tem OPAC (catálogo online):

9. Orçamento:

\section{B) APARELHO LEITOR DE LIVROS ELETRÔNICOS (E-READER)}

10. A biblioteca possui aparelhos especiais para a leitura de livros digitais? Quantos?

11. Qual é o modelo?

12. Foi comprado onde?

13. O software está em português?

14. Pode ser emprestado? Qual o prazo?

\section{C) PROBLEMAS E SOLUÇÕES}

15. Quais foram os modelos de comercialização estudados antes da compra?

16. Quais foram as principais dificuldades encontradas no processo de compra dos livros?

17. Quais foram as principais dificuldades legais encontradas (ex.: licitação)? Como elas foram resolvidas?

18. Quais foram as principais dificuldades financeiras durante o processo?

19. Quais são os principais problemas encontrados em relação à infraestrutura de tecnologia?

20. Como é a aceitação do usuário com os livros eletrônicos?

21. Como é a aceitação dos bibliotecários com os livros eletrônicos? 


\section{D) ACERVO ELETRÔNICO}

\section{VENDEDOR}

22. Como foi feita a escolha do vendedor/fornecedor?

23. Quais critérios foram levados em conta na hora da compra?

24. O fornecedor é um distribuidor, agregador ou editora?

25. Que modelos de negócio são praticados pelo fornecedor?

26. É possível combinar a aquisição através de diferentes modelos?

27. É possível solicitar um período de teste antes da aquisição?

\section{PREÇO}

28. O preço do e-book é igual ao da versão impressa?

29. É necessário pagar uma taxa anual de acesso à plataforma? Em caso afirmativo, qual o período mínimo/máximo durante o qual a taxa deverá ser paga?

30. Há desconto para aquisição de mais de uma cópia do mesmo título (para títulos monousuário)?

31. Há desconto para assinatura (ou pagamento antecipado da taxa de manutenção) por período plurianual?

32. Há desconto para aquisição através de consórcio (se sua biblioteca faz parte de um)?

\section{SELEÇÃO}

33. Quais assuntos são abordados pela coleção?

34. Como foi feita a seleção dos livros (por título, pacote, pay-per-view, PDA/DDA)?

\section{PAGAMENTO}

35. Foi feita a compra ou a assinatura anual dos títulos? Se foi por assinatura, é permitida a troca anual?

36. Qual é o período da licença?

37. Quando é o próximo pagamento?

\section{CONTEÚDO}

38. Possui o conteúdo específico que a biblioteca necessita, incluindo bibliografia básica e complementar?

39. Os títulos disponíveis são relevantes para as áreas de ensino e pesquisa da instituição? 
Possui obras de autores reconhecidos nessas áreas?

40. As edições mais recentes dos e-books estão disponíveis no catálogo?

41. Qual o período de embargo para inclusão de uma nova edição no catálogo, se houver?

42. O conteúdo é publicado em vários países e em vários idiomas? Inclui conteúdo em português?

43. Os e-books incluem todo o material que está na versão impressa, inclusive imagens e gráficos?

44. Os e-books contém algum material adicional, como áudio, vídeo e multimídia?

\section{INTERFACE DE ACESSO DO USUÁRIO}

45. É necessário o uso de algum programa (software) em especial para acesso aos livros? Qual?

46. É possível fazer o download do livro?

47. A interface tem opção de navegação em português?

48. Exige a instalação de programas ou plug-ins adicionais para leitura?

49. É compatível com o tipo e versão de navegador usado na biblioteca?

50. É possível fazer busca no texto completo?

51. Quais os formatos de e-book disponíveis para leitura e download?

52. Os e-books podem ser lidos em e-readers e outros dispositivos móveis? Em caso afirmativo, quais dispositivos são compatíveis?

53. É possível ler os e-books sem estar conectado à internet (offline)?

54. Possui funcionalidades para marcar, anotar e comentar o texto?

55. É possível copiar e imprimir conteúdo?

56. Possui recursos de acessibilidade, como leitura em voz alta?

57. Como ocorre o acesso do usuário (apenas na área da biblioteca, remoto...)?

58. Quais as formas de acesso local e remoto aos e-books (autenticação de IP, usuário e senha, servidor proxy, URL de referência)?

59. Quem tem acesso ao livro digital?

60. É possível emprestar o livro digital ou partes dele por meio de empréstimo entre bibliotecas?

61. O acesso é de apenas um usuário por vez, múltiplo (2, 3 pessoas) ou ilimitado por 
livro?

62. Há um limite máximo de acessos simultâneos à plataforma?

63. Qual o tempo de empréstimo? É possível renovar?

\section{SUPORTE E TREINAMENTO}

64. Existe suporte técnico local com atendimento em português?

65. É oferecido material para promoção e marketing (cartazes, folhetos, banners)?

66. Existe material de apoio para treinamento (manuais, guias de referência, tutoriais, vídeos)? O material está em português?

67. É oferecido treinamento presencial e/ou virtual para a equipe da biblioteca e para os usuários?

68. É possível obter estatísticas de uso dos e-books? Que tipo de estatísticas estão disponíveis?

69. A biblioteca recebe os registros MARC dos e-books adquiridos/assinados?

70. É possível integrar os e-books ao catálogo da biblioteca?

71. Os metadados e/ou texto completo dos e-books estão indexados em ferramentas de descoberta?

\section{LICENÇA DE USO}

72. A licença descreve o conteúdo que está sendo adquirido e/ou assinado?

73. Estipula de que forma o conteúdo será acessado e utilizado?

74. Determina quem são os usuários autorizados a acessar e utilizar o conteúdo?

75. Os usuários autorizados incluem todos os potenciais usuários da biblioteca?

76. Descreve os termos de DRM e as restrições existentes para leitura, impressão, cópia, download, e empréstimo entre bibliotecas?

77. Prevê a entrega de estatísticas de uso, seu conteúdo, formato e periodicidade em que serão apresentadas?

78. Qual o nível de serviço contratado e o que ele inclui (suporte técnico local e remoto, atendimento em idioma local, prazo para atendimento de solicitações, serviços específicos a serem disponibilizados)?

79. Determina quem é responsável pelo armazenamento e preservação dos arquivos?

\section{PREOCUPAÇÕES LEGAIS}

80. Quais são os direitos da biblioteca? 
81. A biblioteca está protegida de uso não autorizado por parte dos usuários se ela tomou as medidas necessárias para prevenir esse uso (ex.: quebra do DRM, impressão do livro completo, cópia não autorizada)?

82. Existe alguma área onde a responsabilidade (liability, responsabilidade legal) pode ser um problema?

83. O vendedor vai oferecer cópias para arquivo de algum livro comprado caso encerre sua plataforma ou seus negócios? 


\section{Apêndice C - Segunda versão do formulário da entrevista}

\section{A) DADOS DA BIBLIOTECA}

1. Nome da biblioteca:

2. Órgão vinculado:

3. Número de funcionários:

4. Quantidade de bibliotecários:

5. Tipo de biblioteca (Universitária, pública, especializada etc.):

6. Acervo:

7. Sistema de automação:

8. Tem OPAC (catálogo on-line):

9. Orçamento:

B) VENDEDORES

10. A política de desenvolvimento de coleções da biblioteca inclui livros eletrônicos ou outros recursos digitais?

11. Quais são as principais diferenças entre a compra de livros impressos e eletrônicos?

12. Por que a biblioteca decidiu comprar livros eletrônicos?

13. Como foi feita a escolha do vendedor/fornecedor?

14. De quais vendedores você compra livros eletrônicos?

15. Esse é o mesmo vendedor do qual a biblioteca compra livros impressos?

16. O vendedor é um distribuidor, agregador ou editora?

17. Quais critérios foram levados em conta na hora da compra?

18. Foi solicitado um período de teste antes da aquisição? Quem participou dele?

19. Quais os formatos de livros eletrônicos disponíveis? 
20. A biblioteca já teve interesse em comprar algum livro eletrônico que não era oferecido para bibliotecas?

\section{SUPORTE DO VENDEDOR}

21. Existe suporte técnico local com atendimento em português?

22. É oferecido treinamento presencial e/ou virtual para a equipe da biblioteca e para os usuários?

23. Existe material de apoio para treinamento (manuais, guias de referência, tutoriais, vídeos)? O material está em português?

24. É possível obter estatísticas de uso dos livros eletrônicos? Que tipo de estatísticas estão disponíveis?

\section{C) MODELOS DE NEGÓCIOS}

25. Que modelos de negócio são praticados pelo fornecedor (acesso perpétuo, assinatura, empréstimo de curto prazo, aquisição orientada pelo usuário)?

26. Qual foi o modelo escolhido? Por que esse modelo foi escolhido?

27. Em caso de assinatura de pacotes, é possível trocar os títulos que não são utilizados?

28. Existe um limite fixo de número de acessos por título?

\section{D) SELEÇÃO}

29. Como foi feita a seleção dos livros (por título, capítulos, pacote, pay-per-view, PDA/DDA)?

30. Por que esse foi o modelo de seleção escolhido?

31. O vendedor oferece desconto para a compra de pacotes? 
32. A biblioteca podia selecionar os títulos do pacote?

33. O valor do pacote compensava os títulos não desejados?

34. As edições dos livros são atualizadas automaticamente ou é necessário fazer uma nova assinatura?

35. A biblioteca tem possibilidade de acessar as edições anteriores?

36. Os livros sofrem algum período de embargo?

37. Quais são os critérios utilizados para decidir se a assinatura dos livros será renovada ou cancelada?

\section{E) MEIO DE ACESSO E USO}

38. O acesso é oferecido pela plataforma do vendedor ou em uma plataforma própria?

39. É necessário pagar uma taxa anual de acesso à plataforma? Em caso afirmativo, qual o período mínimo/máximo durante o qual a taxa deverá ser paga?

40. É necessário o uso de algum programa (software) em especial para acesso aos livros? Qual?

41. Quem tem acesso ao livro digital?

42. O acesso é online ou por download?

43. É possível ler os livros sem estar conectado à Internet (Off-line)?

44. Qual é o período de empréstimo? É possível renovar?

45. Quais as formas de acesso local aos livros?

46. Quais as formas de acesso remoto aos livros (autenticação de IP, usuário e senha, servidor proxy, URL de referência)?

47. Os livros podem ser lidos em e-readers e outros dispositivos móveis? Em caso afirmativo, quais dispositivos são compatíveis?

48. A interface tem opção de navegação em português?

49. É possível fazer busca no texto completo? 
50. Possui funcionalidades para marcar, anotar e comentar o texto?

51. É possível copiar e imprimir conteúdo?

52. É possível integrar os livros ao catálogo da biblioteca?

\section{F) MODELOS DE ACESSO DOS USUÁRIOS}

53. O acesso é de apenas um usuário por vez, múltiplo (2, 3 pessoas) ou ilimitado por livro?

54. Por que esse modelo foi escolhido?

55. Há um limite máximo de acessos simultâneos à plataforma?

G) LICENÇA DE VENDA

56. Quem é responsável pela negociação com os vendedores?

57. A licença estipula de que forma o conteúdo será acessado e utilizado?

58. A licença determina quem são os usuários autorizados a acessar e utilizar o conteúdo?

59. A licença descreve os termos de DRM e as restrições existentes para leitura, impressão, cópia, download, e empréstimo entre bibliotecas?

60. Qual o nível de serviço contratado e o que ele inclui (suporte técnico local e remoto, atendimento em idioma local, prazo para atendimento de solicitações, serviços específicos a serem disponibilizados)?

61. Quais são os direitos da biblioteca?

62. A biblioteca está protegida de uso não autorizado por parte dos usuários se ela tomou as medidas necessárias para prevenir esse uso (ex.: quebra do DRM, impressão do livro completo, cópia não autorizada)?

63. A licença determina quem é responsável pelo armazenamento e preservação dos arquivos?

64. Caso uma editora decida sair da plataforma, a biblioteca tem alguma garantia de acesso ao material comprado? 
65. O vendedor vai oferecer cópias para arquivo de algum livro comprado caso encerre sua plataforma ou seus negócios?

66. Quais foram as principais dificuldades legais encontradas para a compra (ex.: licitação)? Como elas foram resolvidas? 


\section{Apêndice D - Autorização para gravação}

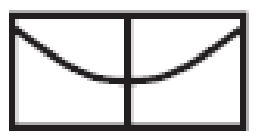

Universidade de Brasília (UnB)

Faculdade de Ciência da Informação (FCI)

Programa de Pós-Graduação em Ciência da Informação

TERMO DE AUTORIZAÇÃO PARA GRAVAÇÃO DE VOZ

$\mathrm{Eu}$,

, AUTORIZO, por meio deste termo, a pesquisadora Raquel Pereira Costa, aluna do curso de Mestrado em Ciência da Informação da Universidade de Brasília, que pode ser contatada pelo e-mail pereiracostaraquel@gmail.com e pelos telefones (61) 3034-4559 e (61) 8220-5477, a realizar a gravação de minha entrevista sem custos financeiros a nenhuma parte.

Esta AUTORIZAÇÃ̃o foi concedida mediante o compromisso da pesquisadora acima citada em garantir-me os seguintes direitos:

1. poderei ler a transcrição de minha gravação;

2. os dados coletados serão usados exclusivamente para gerar informações para a pesquisa aqui relatada e outras publicações dela decorrentes, quais sejam: revistas científicas, congressos e jornais;

3. minha identificação não será revelada em nenhuma das vias de publicação das informações geradas;

4. qualquer outra forma de utilização dessas informações somente poderá ser feita mediante minha autorização;

5. os dados coletados serão guardados por 5 anos, sob a responsabilidade do(a) pesquisador(a) coordenador(a) da pesquisa, e após esse período, serão destruídos e,

6. serei livre para interromper minha participação na pesquisa a qualquer momento e/ou solicitar a posse da gravação e transcrição de minha entrevista.

Brasília, de de

\section{Assinatura do participante da pesquisa}

\section{Assinatura da pesquisadora}




\section{Apêndice E - Lista das bibliotecas}

\section{Bibliotecas que participaram da pesquisa}

Universidade Pública

1. Universidade de Brasília - Biblioteca Central

Universidade Privada

2. Unieuro - Biblioteca Hilson Antônio Bona

3. Uniceub - Biblioteca Reitor João Herculino

Executivo

4. Serpro - Biblioteca do Serpro

5. Empresa Brasileira de Pesquisa Agropecuária (EMBRAPA) - Biblioteca Edmundo da Fontoura Gastal

Judiciário

6. Tribunal de Justiça do Distrito Federal e Territórios (TJDFT) - Desembargador Antônio Mello Martins

7. Superior Tribunal de Justiça (STJ) - Biblioteca Ministro Oscar Saraiva

Legislativo

8. Tribunal de Contas da União - Biblioteca Ministro Rubem Rosa

ONGs

9. Hospital Sarah - Biblioteca do Hospital Sarah

10. Caixa Seguros - Centro de Documentação e Informação

\section{Bibliotecas que não participaram da pesquisa}

Escola privada

1. Conselho Cultural Thomas Jefferson - Resource Center

Universidade Pública

2. Instituto Federal de Brasília (IFB) - Biblioteca

Universidade Privada

3. Faculdade de Ciências Sociais e Tecnológicas (Facitec) - Biblioteca Assis Chateaubriand

4. IESB - Biblioteca Terezinha Sanways

Executivo

5. Agência Nacional de Transportes Aquaviários (Antaq) - Biblioteca da Antaq

Judiciário

6. Ministério Público Militar - Departamento de Documentação e Informação

7. Procuradoria Geral do Distrito Federal (PGDF) - Biblioteca Onofre Gontijo Mendes

8. Supremo Tribunal Federal (STF) - Biblioteca Ministro Victor Nunes Leal

9. Tribunal Regional Eleitoral do Distrito Federal (TRE DF) - Biblioteca Geraldo Irenêo Joffily

10. Tribunal Regional Federal (TRF) 1a Região - Biblioteca Ministro Adhemar Maciel 
Legislativo

11. Câmara dos Deputados - Biblioteca Pedro Aleixo

12. Câmara Legislativa do Distrito Federal (CLDF) - Setor de Biblioteca

ONGs

13. Fundação Getúlio Vargas (FGV) - Biblioteca da Fundação Getúlio Vargas

14. Instituto Cervantes - Biblioteca Ángel Crespo 